DCN 96-218-073-04

\author{
DEMONSTRATION OF SELECTIVE CATALYTIC \\ REDUCTION (SCR) TECHNOLOGY FOR THE CONTROL \\ OF NITROGEN OXIDE (NO $)$ EMISSIONS \\ FROM HIGH-SULFUR COAL-FIRED BOILERS
}

Plant Crist

Environmental Monitoring Program

Final Report

DOE DE-FC22-90PC89652

SCS C-91-000026

Prepared for:

Southern Company Services, Inc.

600 North 18th Street

P. O. Box 2625

Birmingham, Alabama 35202-2625

Prepared by:

Radian International LLC

8501 North Mopac Boulevard

P. O. Box 201088

Austin, Texas 78720-1088

Cleared by DOE Patent Counsel on July 17, 1996.

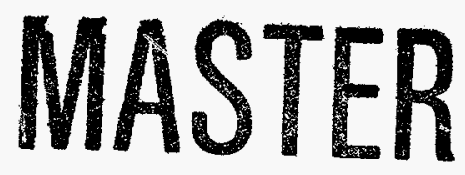

DSTRIBUTION OF THS DOCUNENT IS UNLMATED 


\section{DISCLAIMER}

Portions of this document may be illegible in electronic image products. Images are produced from the best available original document. 


\begin{tabular}{l|l}
\hline & \\
\hline (Mailing) P.0. Box 201088 \\
\hline Austin, TX 78720-1088 \\
\hline (Shipping) 8501 N. Mopac Blvd. \\
\hline Austin, TX 78759 \\
\hline (512) 454-4797 \\
\hline
\end{tabular}

DEMONSTRATION OF SELECTIVE CATALYTIC REDUCTION (SCR) TECHNOLOGY FOR THE CONTROL OF NITROGEN OXIDE (NO,) EMISSIONS FROM HIGH-SULFUR COAL-FIRED BOILERS

\title{
Plant Crist
}

Environmental Monitoring Program

\section{Final Report}

DOE DE-FC22-90PC89652

SCS C-91-000026

\author{
Prepared for: \\ Southern Company Services, Inc. \\ 600 North 18th Street \\ P. O. Box 2625 \\ Birmingham, Alabama 35202-2625
}

Prepared by:

Radian International LLC 8501 North Mopac Boulevard

P. O. Box 201088

Austin, Texas 78720-1088

Cleared by DOE Patent Counsel on July 17, 1996. 


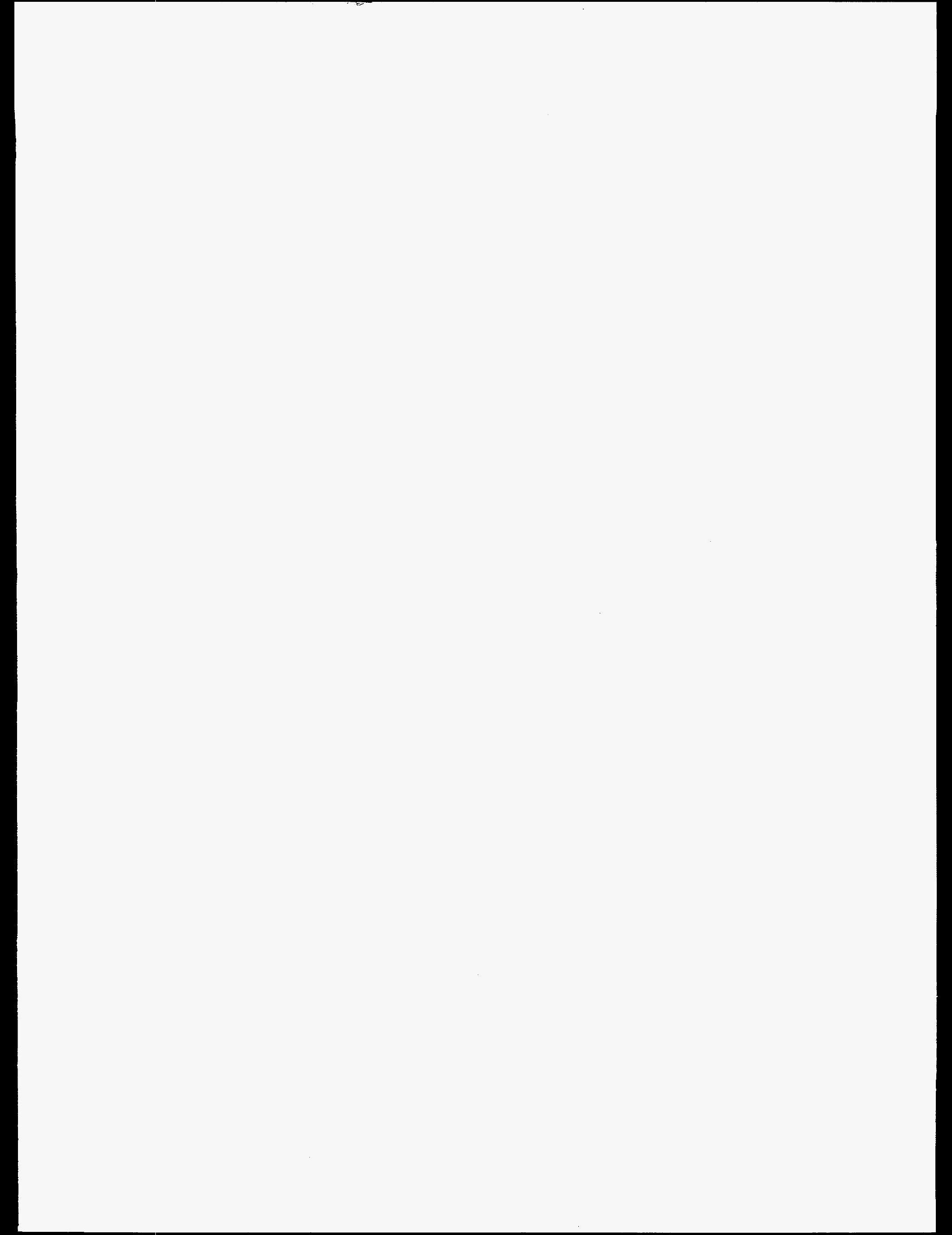




\section{Executive Summary}

This report contains a summary and discussion of the results of Environmental Monitoring Program (EMP) activities conducted during the Clean Coal Technology (CCT) project entitled "Demonstration of Selective Catalytic Reduction (SCR) Technology for the Control of Nitrogen Oxide $\left(\mathrm{NO}_{x}\right)$ Emissions from High-Sulfur Coal-Fired Boilers." This project was conducted using flue gas from Unit 5 at Gulf Power Company's Plant Crist, located near Pensacola, Florida.

The primary goal of this project was to demonstrate the use of SCR to reduce $\mathrm{NO}_{\mathrm{x}}$ emissions from pulverized-coal utility boilers using high-sulfur U.S. coal. The SCR test facility, built in and around the ductwork of Plant Crist Unit 5, consisted of three large SCR reactor units (Reactors A, B, and C), each with a design capacity of 5,000 standard cubic feet per minute (scfm) of flue gas, and six smaller reactors (Reactors D through $\mathfrak{J}$ ), each with a design capacity of $400 \mathrm{scfm}$ of flue gas. The three large reactors contained commercially available SCR catalysts as offered by SCR catalyst suppliers. These reactors were coupled with small-scale air preheaters to evaluate (1) the long-term effects of SCR reaction chemistry on air preheater deposit formation and (2) the impact of these deposits on the performance of air preheaters. The small reactors were used to test additional varieties of commercially available catalysts.

The demonstration project was organized into three phases: (1) Phase I-Permitting, Environmental Monitoring Plan Preparation and Preliminary Engineering; (2) Phase II-Detail Design Engineering and Construction; and (3) Phase III-Operation, Testing, Disposition, and Final Report Preparation. All EMP monitoring was conducted during Phase III and included supplemental sampling and analysis of the Unit 5 feed coal and a number of SCR reactor inlet and outlet streams, together with compliance monitoring of the ash pond discharge. The Testing Phase consisted of four tasks, as follows:

- Task 1 (commissioning without catalysts and without ammonia injection) involved calibration of the venturi flow controllers upstream of each reactor; measurement of particle mass concentrations at the inlet and outlet of the Unit 5 hot-side electrostatic precipitator (ESP) at high and low load conditions; measurement of the particle mass loadings in the economizer bypass at low-load conditions and verification of the similarity of the particulate loadings, size distributions, and composition of the fly ash collected inside the eight high-dust reactors; measurement of baseline gas-phase flue gas composition; and 
determination of the degree of conversion of $\mathrm{SO}_{2}$ to $\mathrm{SO}_{3}$ across one large and one small reactor.

- Task 2 (commissioning without catalysts and with ammonia injection) was conducted to verify ammonia flow control, establish an ammonia mass balance, and measure ammonia loss in the absence of catalyst. Ammonia loss was measured on one large reactor and one small reactor.

- Task 3A (commissioning with catalysts and without ammonia injection) was combined with Task 3B (preliminary parametric tests). Tests were conducted to examine the conversion of $\mathrm{SO}_{2}$ to $\mathrm{SO}_{3}$ across the $\mathrm{SCR}$ reactors with catalysts installed and to evaluate the initial performance of the reactors with catalysts installed and with ammonia injection. Although the $\mathrm{SO}_{2}$ conversion tests had originally been planned without ammonia injection, the tests were actually conducted with ammonia injection.

- Task 4 (long-term parametric tests) was intended to evaluate the long-term performance of the SCR reactors with catalysts installed and with ammonia injection. The parametric tests in this task included four additional series of tests in which measurements were made of a number of gas-phase constituents at various combinations of flue gas flow rate, temperature, and $\mathrm{NH}_{3} / \mathrm{NO}_{\mathrm{x}}$ ratio. When not undergoing parametric tests, each reactor was returned to its baseline operating condition for long-term performance evaluation.

In response to procedures developed by the Department of Energy to comply with the National Environmental Policy Act (NEPA) requirements, Southern Company Services was required to develop and implement an Environmental Monitoring Plan (EMP) for the Selective Catalytic Reduction Demonstration Project at Plant Crist (1). The EMP was developed to fulfill the following specific objectives:

- To provide monitoring data to fulfill project-related environmental compliance requirements of local, state, and federal regulatory agencies;

- To define and describe supplemental monitoring activities;

- To ensure that emissions and environmental impacts were consistent with projections provided in NEPA documents; and

- To develop an environmental record that can be used for future replication of the subject technology. 
The following paragraphs summarize the results obtained from the EMP monitoring conducted during the SCR demonstration project. Detailed results of the project testing may be found in the Final Project Report (2).

- Apparent $\mathrm{NO}_{\mathrm{x}}$ reduction efficiencies measured during the parametric tests showed that all of the SCR catalysts were capable of reductions from about 50 to nearly $100 \%$, depending on reactor operating conditions. The mean reduction and observed range for each reactor, based on the parametric test data, are summarized below:

\begin{tabular}{||c|c|c|c||}
\hline \multirow{2}{*}{ Reactor } & \multicolumn{2}{|c|}{ Apparent NO Reduction Efficiencies, \% } & NH $_{3}$ Slip, ppmv \\
\cline { 2 - 4 } & Mean & Range & Range \\
\hline \hline A & 79.9 & $61.8-94.1$ & $0.8-29$ \\
\hline B & 84.5 & $66.9-99.8$ & $<0.7-35.3$ \\
\hline C & 88.9 & $69.5-99.2$ & $0.8-58$ \\
\hline D & 89.1 & $80.9-96.7$ & $<1.3-94.1$ \\
\hline E & 81.7 & $62.0-93.9$ & $<0.1-68$ \\
\hline F & 84.7 & $70.6-96.0$ & $<0.8-90.1$ \\
\hline G & 78.2 & $64.3-88.8$ & $<0.7-94.1$ \\
\hline J & 68.7 & $51.2-85.7$ & $<0.8-24.4$ \\
\hline
\end{tabular}

These reduction efficiencies should not be construed as necessarily reflecting the -. relative performance of the different catalysts in the reactors. Many factors impact the $\mathrm{NO}_{\mathrm{x}}$ reduction efficiencies, and all of the reactors may not have experienced the same sequence of test parameters. In many cases, very high reductions efficiencies were achieved at conditions that may not be practical in routine operation. For example, at very high $\mathrm{NO}_{\mathrm{x}}$ reduction efficiencies, ammonia slip could be as high as $90 \mathrm{ppmv}$. The ranges of ammonia slip measured during the parametric test sequences are also included in the table.

- In general, changes to the major SCR reactor operating parameters had the following impacts:

- Increasing the $\mathrm{NH}_{3} \mathrm{NO}_{\mathrm{x}}$ ratio resulted in greater $\mathrm{NO}_{\mathrm{x}}$ reduction efficiency and increased ammonia slip.

- Increasing SCR reactor residence time (i.e., reducing the flue gas flow rate) resulted in greater $\mathrm{NO}_{\mathrm{x}}$ reduction efficiency and reduced ammonia slip.

- Increasing reactor temperature did not have a definitive impact on $\mathrm{NO}_{\mathrm{x}}$ reduction efficiency, but ammonia slip was reduced.

- The $\mathrm{SO}_{3}$ concentration in the flue gas generally increased across the SCR reactors, due to the conversion of a portion of the $\mathrm{SO}_{2}$. The fraction of $\mathrm{SO}_{2}$ converted to $\mathrm{SO}_{3}$ tended to increase with increasing reactor temperature and residence time. In many cases there was a slight decrease in $\mathrm{SO}_{2}$ conversion as catalyst exposure 
time increased. Less than $0.5 \%$ of the $\mathrm{SO}_{2}$ was converted to $\mathrm{SO}_{3}$ in the majority of cases.

- $\mathrm{N}_{2} \mathrm{O}$ concentrations upstream and downstream of the SCR reactors were low, with the observed range varying from 1 to about $3 \mathrm{ppmv}$. No consistent trend toward increasing or decreasing concentration across the SCR reactors was observed; in many cases, there was no significant change in the $\mathrm{N}_{2} \mathrm{O}$ concentrations between SCR reactor inlet and outlet.

- An apparent increase in $\mathrm{HCl}$ concentration across the SCR reactors appeared to be an artifact of the sampling methods used; flue gas particulates were not collected at the SCR reactor inlets, where a portion of the chloride was probably present in the form of solid-phase salts (e.g., ammonium chloride).

- The particulate matter loading was apparently higher at the SCR reactor outlets than at the hot-side ESP inlet located upstream of the reactors. However, the measured ESP inlet loading appeared to have been low, based on subsequent measurements made in the economizer bypass duct at low boiler load conditions. As expected, the average loading was higher at higher boiler load conditions than at low load (i.e., averages of 3.9 and 3.5 grains/dscf, respectively).

- Good agreement was observed in both particulate matter size distribution and composition at the main reactor inlet and downstream of the last catalyst level for each of the SCR reactors.

- Based on the results of the Toxicity Characteristic Leaching Procedure (TCLP) analyses of the fly ash samples obtained at the SCR reactor inlet, reactor outlet, or air preheater outlet, no significant change in characteristics was noted across the SCR reactors, and none of these solids would be classified as hazardous under Title III of RCRA, with respect to the toxic metals.

- As expected, the SCR demonstration project did not have any detectable impact on the measured water quality parameters for the ash pond discharge stream. 


\section{Table of Contents}

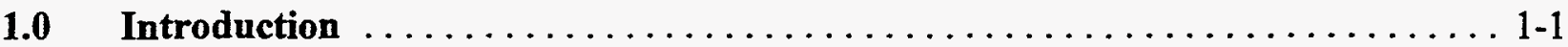

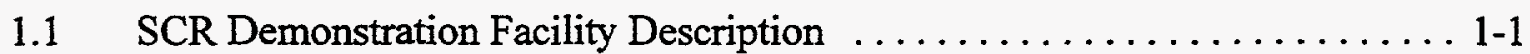

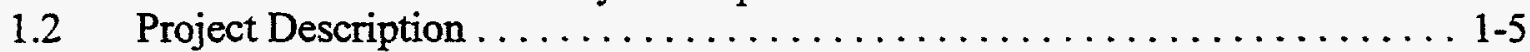

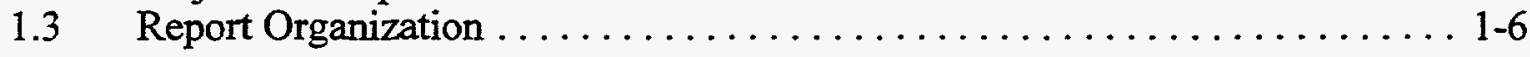

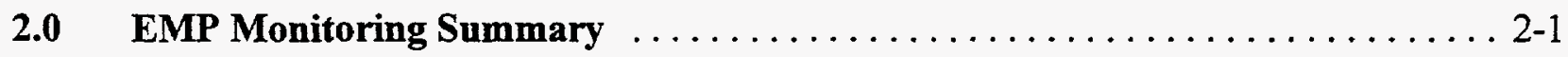

3.0 Sampling and Analytical Methods $\ldots \ldots \ldots \ldots \ldots \ldots \ldots \ldots \ldots \ldots \ldots \ldots \ldots \ldots \ldots$

3.1 Sampling Methods $\ldots \ldots \ldots \ldots \ldots \ldots \ldots \ldots \ldots \ldots \ldots \ldots \ldots \ldots \ldots \ldots \ldots \ldots, 1$

3.2 Analytical Methods $\ldots \ldots \ldots \ldots \ldots \ldots \ldots \ldots \ldots \ldots \ldots \ldots \ldots \ldots \ldots \ldots \ldots \ldots, 1$

4.0 Gaseous Stream Monitoring Results $\ldots \ldots \ldots \ldots \ldots \ldots \ldots \ldots \ldots \ldots, 4,1$

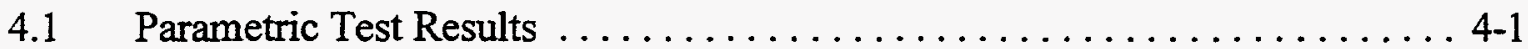

4.1.1 Nitrogen Oxides $\left(\mathrm{NO}_{\mathrm{x}}\right) \ldots \ldots \ldots \ldots \ldots \ldots \ldots \ldots \ldots \ldots \ldots \ldots \ldots \ldots, 1$

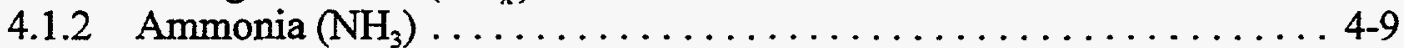

4.1.3 Sulfur Dioxide/Sulfur Trioxide $\left(\mathrm{SO}_{2} / \mathrm{SO}_{3}\right) \ldots \ldots \ldots \ldots \ldots \ldots .4 .9$

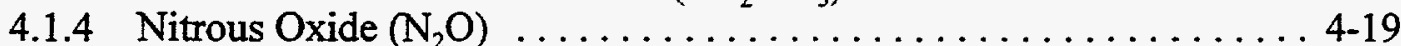

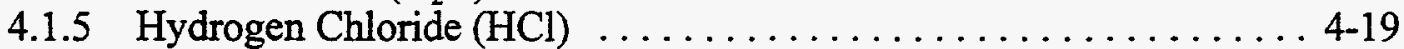

4.1.6 Particulate Matter ................................ 4-28

$4.2 \quad$ Long-Term Monitoring Results $\ldots \ldots \ldots \ldots \ldots \ldots \ldots \ldots \ldots \ldots \ldots, 47$

4.2.1 Nitrogen Oxides $\left(\mathrm{NO}_{\mathrm{x}}\right) \ldots \ldots \ldots \ldots \ldots \ldots \ldots \ldots \ldots \ldots \ldots \ldots \ldots \ldots \ldots, 42$

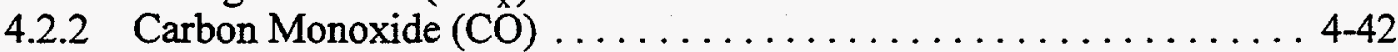

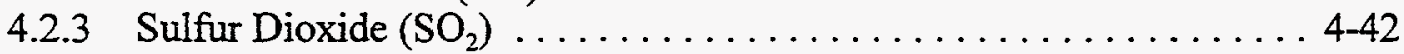

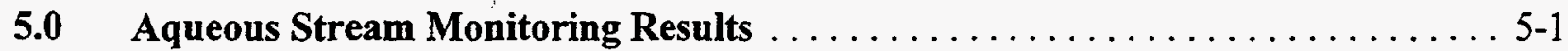

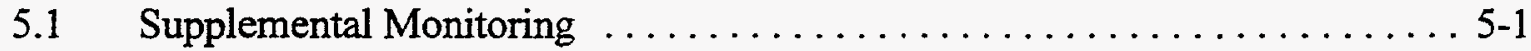

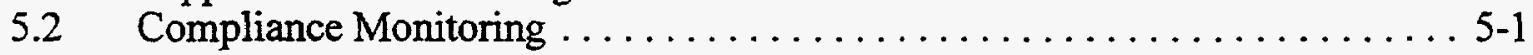

6.0 Solid Stream Monitoring Results $\ldots \ldots \ldots \ldots \ldots \ldots \ldots \ldots \ldots \ldots \ldots, 6,1$

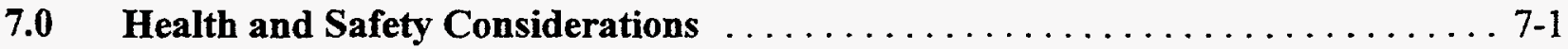

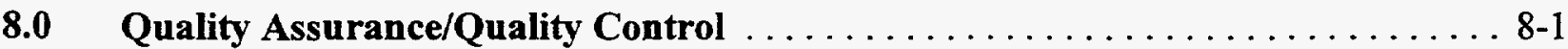

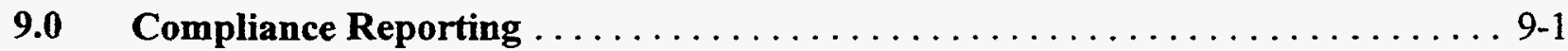




\section{Table of Contents (continued)}

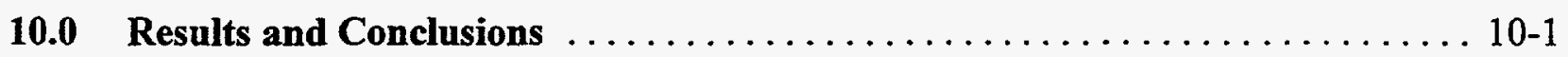

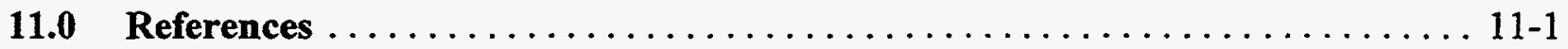

Appendix A: Monitoring Data Summary Tables $\ldots \ldots \ldots \ldots \ldots \ldots \ldots \ldots$ A-1 


\section{List of Figures}

1-1 Prototype SCR Demonstration Facility_Process Flow Diagram $\ldots \ldots \ldots \ldots \ldots$ 1-2

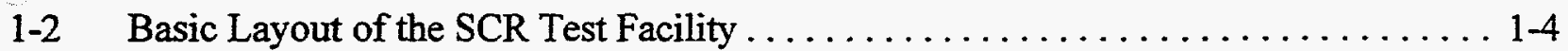

4-1 Impact of Gas Flow Rate and $\mathrm{NH}_{3} \mathrm{NO}_{\mathrm{x}}$ Ratio on $\mathrm{NO}_{\mathrm{x}}$ Reduction: Parametric Tests

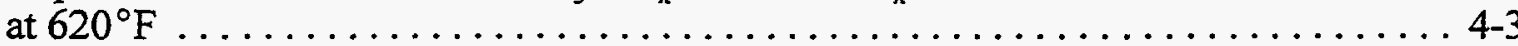

4-2 Impact of Gas Flow Rate and $\mathrm{NH}_{3} \mathrm{NO}_{\mathrm{x}}$ Ratio on $\mathrm{NO}_{\mathrm{x}}$ Reduction: Parametric Tests

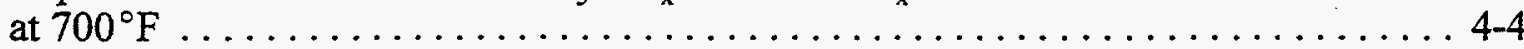

4-3 Impact of $\mathrm{NH}_{3} \mathrm{NO}_{\mathrm{x}}$ Ratio on $\mathrm{NO}_{\mathrm{x}}$ Reduction: Parametric Tests at $750^{\circ} \mathrm{F} \ldots \ldots$ 4-5

4-4 Impact of Reactor Operating Temperature on $\mathrm{NO}_{\mathrm{x}}$ Reduction: Parametric Tests at Design Flow Rate and $\mathrm{NH}_{3} / \mathrm{NO}_{\mathrm{x}}$ Ratio $=0.6 \ldots \ldots \ldots \ldots \ldots \ldots \ldots \ldots, 6$

4-5 Impact of Reactor Operating Temperature on $\mathrm{NO}_{\mathrm{x}}$ Reduction: Parametric Tests at Design Flow Rate and $\mathrm{NH}_{3} / \mathrm{NO}_{\mathrm{x}}$ Ratio $=0.8 \ldots \ldots \ldots \ldots \ldots \ldots \ldots . . \ldots \ldots$

4-6 Impact of Reactor Operating Temperature on $\mathrm{NO}_{x}$ Reduction: Parametric Tests at Design Flow Rate and $\mathrm{NH}_{3} \mathrm{NO}_{x}$ Ratio $=1.0 \ldots \ldots \ldots \ldots \ldots \ldots \ldots \ldots .8$

4-7 Ammonia Loss Across SCR Reactor Without Catalyst: Reactor B . . . . . . . . . 4-10

4-8 Ammonia Loss Across SCR Reactor Without Catalyst: Reactor E . . . . . . . . 4-10

4-9 Effect of Gas Velocity and $\mathrm{NH}_{3} / \mathrm{NO}_{\mathrm{x}}$ Ratio on Ammonia Slip During $620^{\circ} \mathrm{F}$ Parametric Test Series

4-10 Effect of Gas Velocity and $\mathrm{NH}_{3} / \mathrm{NO}_{x}$ Ratio on Ammonia Slip During $700^{\circ} \mathrm{F}$ Parametric Test Series

4-11 Effect of Gas Velocity and $\mathrm{NH}_{3} / \mathrm{NO}_{\mathrm{x}}$ Ratio on Ammonia Slip During $750^{\circ} \mathrm{F}$ Parametric Test Series

4-12 Effect of Temperature on Ammonia Slip: Parametric Tests at Design Flow and $\mathrm{NH}_{3} / \mathrm{NO}_{\mathrm{x}}=0.6$

4-13 Effect of Temperature on Ammonia Slip: Parametric Tests at Design Flow and $\mathrm{NH}_{3} / \mathrm{NO}_{\mathrm{x}}=0.8$

4-14 Effect of Temperature on Ammonia Slip: Parametric Tests at Design Flow and $\mathrm{NH}_{3} / \mathrm{NO}_{\mathrm{x}}=1.0$

4-15 Effect of Temperature on Ammonia Slip: Parametric Tests at $1.5 \times$ Design Flow and $\mathrm{NH}_{3} \mathrm{NO}_{\mathrm{x}}=0.8$

4-16 Variation of Reactor Inlet $\mathrm{SO}_{2}$ Concentration with Coal Sulfur Content $4-20$ 


\section{List of Figures (continued)}

4-17 Example of Variation in $\mathrm{SO}_{2}$ Conversion with Flue Gas Flow and Reactor

Temperature-Reactor A

h.

4-18 Change in $\mathrm{SO}_{2}$ Conversion Across SCR Reactors with Exposure Time

4-19 Reactor Inlet and Outlet Nitrous Oxide Concentrations

4-19 Reactor Inlet and Outlet Nitrous Oxide Concentrations

4-20 Variation in Reactor Outlet $\mathrm{HCl}$ Concentrations with Time

$4-2$

4-21 Reactor Inlet and Outlet Hydrogen Chloride Concentrations

4-22 SCR Reactor Outlet PM Loadings Compared with ESP Inlet Loadings

4-23 Average Particulate Loading at Various Locations in the SCR System

4-24 Differential Particle Size Distribution for Fly Ash Collected Downstream of the

I. . . Third Reactor Level (High-Dust Reactors) During High-Load Tests

4-25 Differential Particle Size Distribution for Fly Ash Collected Downstream of the

4. 2. Third Reactor Level (High-Dust Reactors) During Low-Load Tests

4-26. Comparison of Differential Particle Size Distributions: Hot-Side ESP Inlet and Average of High-Dust Reactors at High Load . . . . . . . . . . . . . . . 4-34

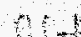

4-27 Comparison of Differential Particle Size Distributions: Hot-Side ESP Inlet and Average of High-Dust Reactors at Low Load $\ldots \ldots \ldots \ldots \ldots \ldots \ldots \ldots \ldots .4 .34$

4-28 Variation in Ammonia Concentration on Flue Gas Particulate Matter with $\mathrm{NH}_{3}$-to-NO $\mathrm{Natio}_{\mathrm{x}}$

4-29 Variation in Ammonia Concentration on Flue Gas Particulate Matter with Particle Size

4-30 Mass Fraction of Ammonia on Flue Gas Particulate Matter Versus Particle Size . . 4-40

4-31 Monthly Average Reactor Inlet CO Concentration During the SCR Demonstration

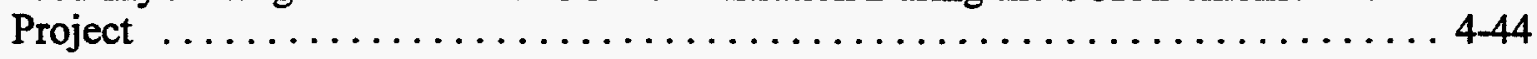

4-32 Monthly Average Reactor Inlet $\mathrm{SO}_{2}$ Concentration During the SCR Demonstration Project 


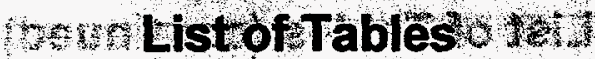

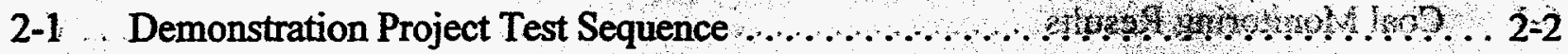

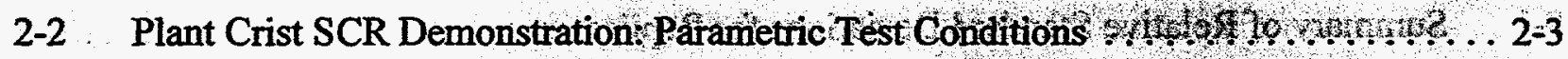

2-3 Gaseous Streams: Integrated Monitoring Schedule, SCR Demonstration Project . . . . 2-4

2-4 Aqueous Streams: Integrated Monitoring Schedule, SCR Demonstration Project ... 2-5

2-5 Solid Streams: Integrated Monitoring Schedule, SCR Demonstration Project ... . . 2-6

2-6 Gaseous Stream Monitoring Summary: Number of Data Points for Non-

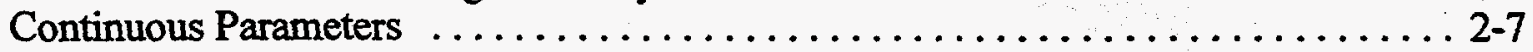

3-1 Sampling and Analytical Methods Summary: Gaseous Streams $\ldots \ldots \ldots \ldots \ldots$ 3-2

3-2 Sampling and Analytical Methods: Aqueous Streams $\ldots \ldots \ldots \ldots \ldots \ldots \ldots$

3-3 Sampling and Analytical Methods: Solid Streams $\ldots \ldots \ldots \ldots \ldots \ldots \ldots \ldots \ldots$

4-1 SCR Reactor Mean Apparent $\mathrm{NO}_{\mathrm{x}}$ Reductions Across SCR Reactors During

Parametric Tests . . . . . . . . . . . . . . . . . . . .

4-2 Mean Ammonia Slip Concentrations During Parametric Tests ............ 4-11

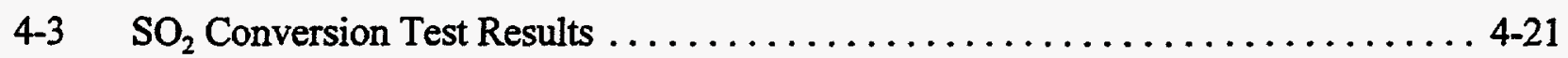

4-4 Mean Nitrous Oxide Concentration Summary $\ldots \ldots \ldots \ldots \ldots \ldots \ldots \ldots . . \ldots .4 .24$

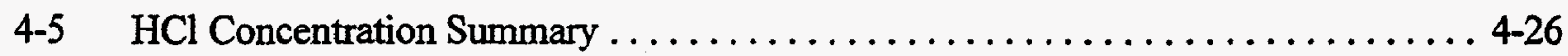

4-6 Average SCR Reactor Outlet PM Loadings..................... 4-29

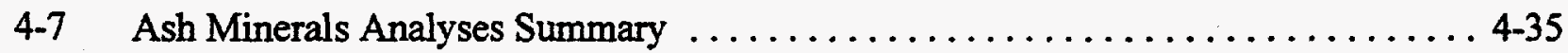

4-8 Trace Metals Concentrations in Ash Samples ................... 4-36

4-9 Ammonia Concentrations in Flue Gas Particulates . . . . . . . . . . . . . . 4

4-10 Size Dependency of Air Preheater Outlet Particulate Ammonia Concentration . . . . 4 48

4-11 Results of TCLP Metals Analyses: SCR Reactor Solids $\ldots \ldots \ldots \ldots \ldots \ldots .4-41$

4-12 Long-Term SCR Reactor Inlet and Outlet $\mathrm{NO}_{\mathrm{x}}$ Concentrations and Reductions

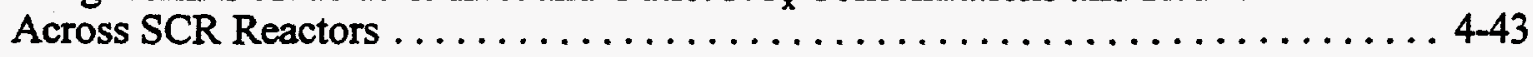

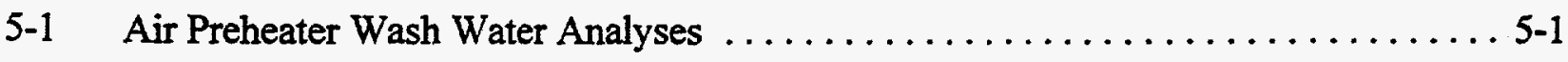

5-2 Ash Pond Discharge Monitoring Summary $\ldots \ldots \ldots \ldots \ldots \ldots \ldots \ldots \ldots \ldots \ldots$ 


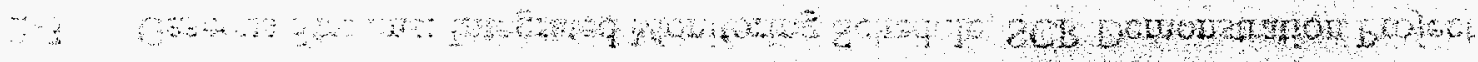

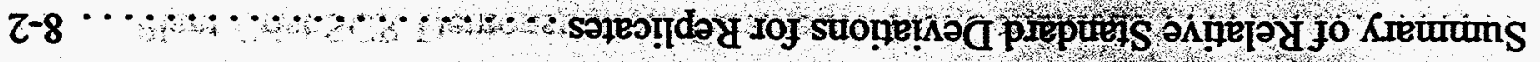
$[-8$ $[-9$

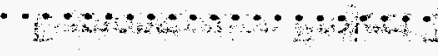
$+2+2, \ldots$ 


\subsection{Introduction}

The purpose of the Clean Coal Technology (CCT) project conducted at Plant Crist was to demonstrate the use of selective catalytic reduction (SCR) to reduce $\mathrm{NO}_{\mathrm{x}}$ emissions from pulverized-coal utility boilers using high-sulfur U.S. coal.

In response to procedures developed by the Department of Energy to comply with the National Environmental Policy Act (NEPA) requirements, Southern Company Services was required to develop and implement an Environmental Monitoring Plan (EMP) for the Selective Catalytic Reduction demonstration project at Plant Crist (1). The EMP was developed to fulfill the following specific objectives:

- To provide monitoring data to fulfill project-related environmental compliance requirements of local, state, and federal regulatory agencies:

- To define and describe supplemental monitoring activities;

- To ensure that emissions and environmental impacts were consistent with projections provided in NEPA documents; and

- To develop an environmental record that can be used for future replication of the subject technology.

This report presents and discusses the data obtained during the SCR demonstration project in fulfillment of the EMP objectives.

\subsection{SCR Demonstration Facility Description}

The SCR test facility was built in and around the ductwork of Plant Crist Unit 5. A simplified schematic flow diagram for the SCR test facility is shown in Figure 1-1.

The SCR facility consisted of three large SCR reactors, each with a design capacity of 5,000 standard cubic feet per minute (scfm) of flue gas, and six smaller reactors, each with a design capacity of $400 \mathrm{scfm}$ of flue gas. With all of the SCR reactors in operation, the total equivalent capacity of the SCR project was $8.7 \mathrm{MW}$ (representing approximately $10 \%$ of the fullload capacity of Unit 5 and less than $1 \%$ of the entire plant's flue gas volume). 


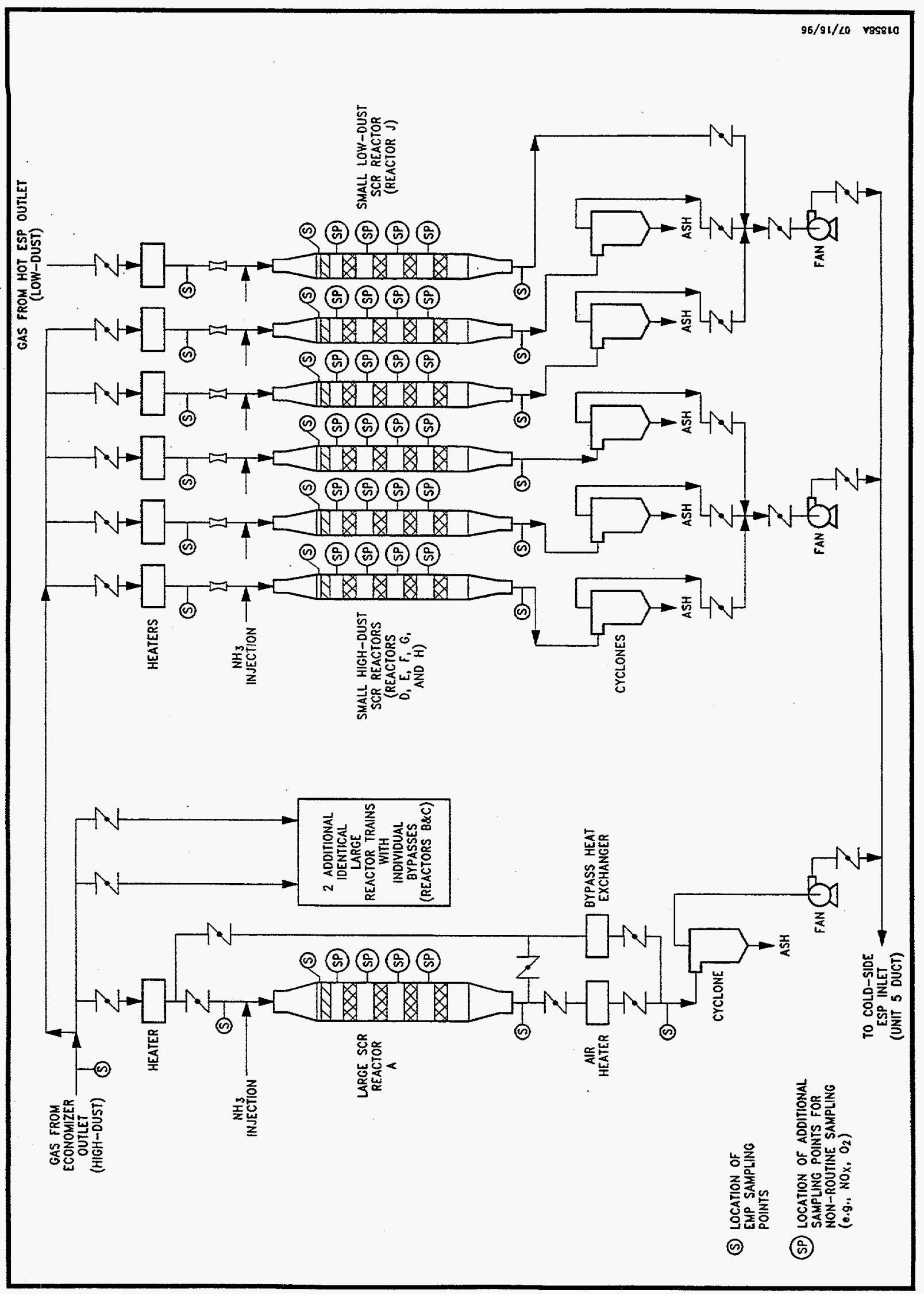

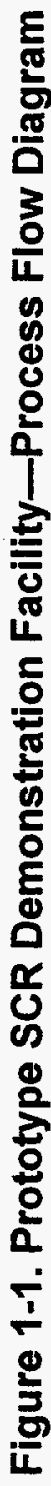


The SCR test facility had the capability of extracting representative flue gas from either of two main power plant duct locations at Plant Crist:

- Unit 5 upstream of the hot-side electrostatic precipitator (ESP) (i.e., Unit 5 high dust); and

- Unit 5 downstream of the hot-side ESP (Unit 5 low dust).

Flue gas extraction was accomplished by inserting gas sampling scoops into the flue gas stream from the host boiler. The high-dust extracted gas supplied the three large reactors (Reactors A, B, and C) and five of the small reactors (Reactors D, E, F, G, and H). The low-dust stream supplied a single small reactor (Reactor J). The high-dust stream was divided at the main extraction scoop header, and the gas was supplied to each of the eight high-dust reactors via individual ducts.

Before the gas entered the SCR reactors, ammonia was injected into the flue gas to facilitate the $\mathrm{NO}_{\mathrm{x}}$ reduction process. The $\mathrm{NO}_{\mathrm{x}}$ removal efficiency and other parameters were measured before the treated gas was discharged into the main flue gas duct upstream of the existing cold-side precipitators for particulate removal and discharge to the atmosphere.

Flue gas flow rates through each reactor were monitored by in-line, full-flow venturis placed downstream of electric in-duct heaters. These in-duct heaters were included so the inlet gas temperatures could be controlled to specified levels. Thus, each venturi measured gas flow under reasonably constant gas temperature conditions. The heaters were required since the boiler economizer outlet temperature varied with boiler load and ranged between 590 and $690^{\circ} \mathrm{F}$, while the design temperature for the SCR unit was $700^{\circ} \mathrm{F}$ (although tests were conducted at higher and lower temperatures).

Figure 1-2 shows a simplified layout of the SCR test facility. For both the large and small reactors, the transition piece from the main supply duct was designed to reduce the gas flow from 60 feet per second (fps) to $14.6 \mathrm{fps}$, and to assure that the gas velocity was uniform across the reactor cross-section. The dimensions of the large reactors were approximately $3^{\prime} 6^{\prime \prime}$ x $4^{\prime} 6^{\prime \prime}$ x $40^{\prime} 0^{\prime \prime}$ (length). The small reactors were approximately $11^{\prime} 1 "$ square $x 40 ' 0$ " (length). 


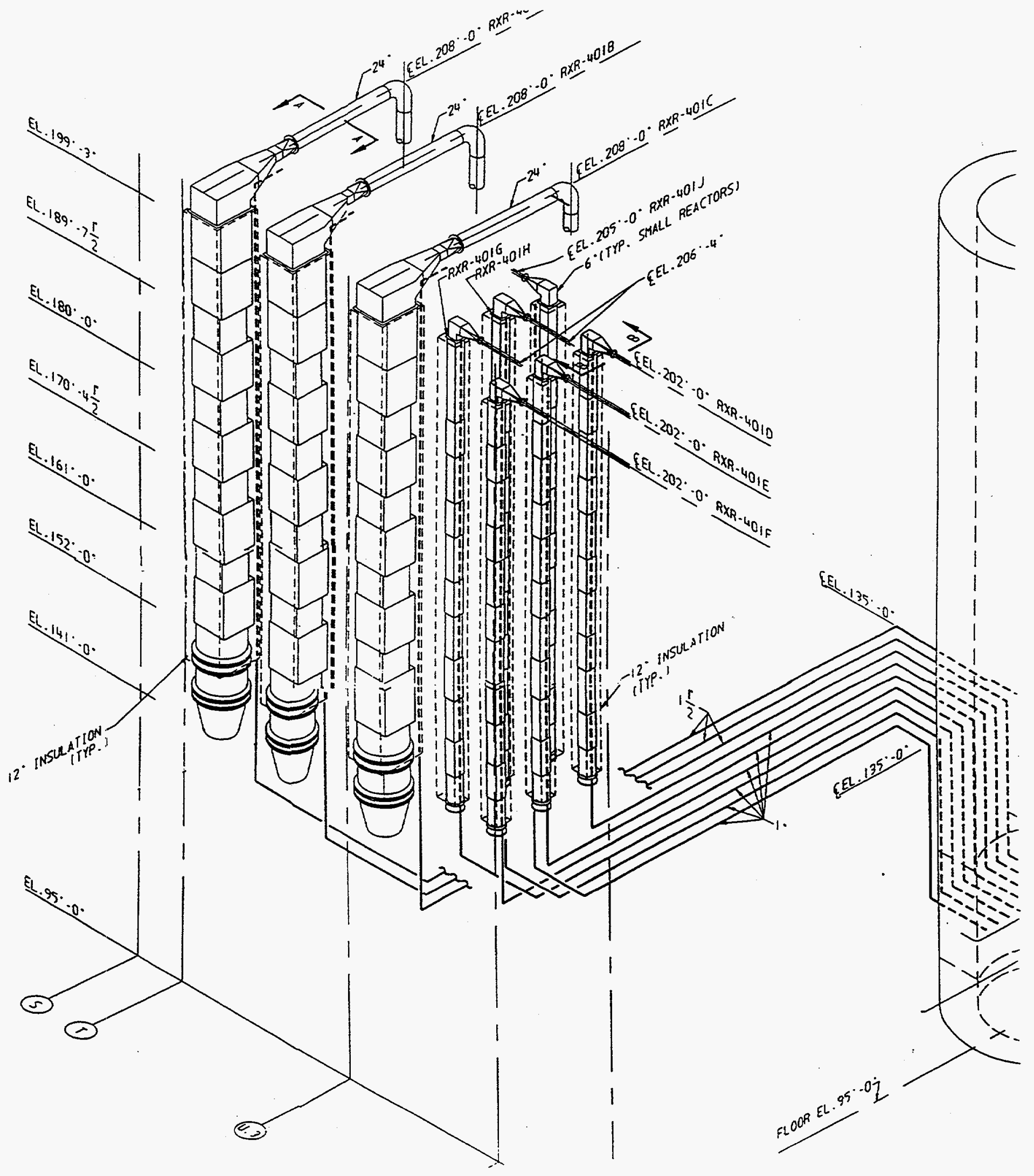

Figure 1-2. Basic Layout of the SCR Test Facility 
As the gas exited the large reactors, it passed through a transition piece at the SCR reactor outlet and directly into the pilot air preheaters. Pilot air preheaters on two of the large reactors (Reactors A and B) simulated full-scale utility rotary air heaters of slightly different designs. The air heater on the third large reactor (Reactor $\mathrm{C}$ ) was a heat pipe design.

As the flue gas exited each air heater, it passed through a cyclone for particulate removal (to protect the ID fans), a louvered damper (used to modulate flow based on venturi flow signals), and an ID fan. The ID fan could operate between 3,000 and 7,500 scfm (with a design, continuous operating capacity of $5,000 \mathrm{scfm}$ ). The flue gas exiting the small reactors passed through cyclones and louvered dampers to ID fans. No air heaters were provided on the small reactors.

The SCR test facility evaluated commercially-available SCR catalysts obtained from world-wide vendors. Details of the catalysts used in each reactor, their vendors, and catalyst configurations are provided in the project's final report prepared by Southern Company Services, Inc. (2).

\subsection{Project Description}

The operational and testing phase of the SCR demonstration project was divided into four tasks, as follows:

- Task 1 (commissioning without catalysts and without ammonia injection) involved calibration of the venturi flow controllers upstream of each reactor; measurement of particle mass concentration at the inlet and outlet of the Unit 5 hot-side electrostatic precipitator (ESP) at high- and low-load conditions; measurement of the particle mass loadings in the economizer bypass duct at low load, and verification of the similarity of the particulate loadings, size distributions, and composition of the fly ash collected inside the eight high-dust reactors; measurement of baseline gas-phase flue gas composition; and determination of the degree of conversion of $\mathrm{SO}_{2}$ to $\mathrm{SO}_{3}$ across one large and one small reactor.

- Task 2 (commissioning without catalysts and with ammonia injection) was conducted to verify ammonia flow control, establish an ammonia mass balance, and measure ammonia loss in the absence of catalyst. Ammonia loss was measured across one large reactor and one small reactor.

- Task 3A (commissioning with catalysts and without ammonia injection) was combined with Task 3B (Preliminary Parametric Tests). Tests were conducted to examine the degree of conversion of $\mathrm{SO}_{2}$ to $\mathrm{SO}_{3}$ across the $\mathrm{SCR}$ reactors with 
catalysts installed and to evaluate the initial performance of the reactors with catalysts installed and with ammonia injection. Although the $\mathrm{SO}_{2}$ conversion tests were originally planned without ammonia injection, the tests were actually conducted with ammonia injection.

- Task 4 (Long-Term Parametric Tests) was performed to evaluate the long-term performance of the SCR reactors with catalyst installed and with ammonia injection. The parametric tests included in this Task included measurements of a number of gas-phase constituents at various combinations of flue gas flow rate, temperature, and $\mathrm{NH}_{3} / \mathrm{NO}_{x}$ ratio. When not undergoing parametric tests, each reactor was returned to its baseline operating condition for long-term performance evaluation.

\subsection{Report Organization}

The remainder of this report is organized as follows:

- Section 2 discusses the planned and actual EMP monitoring for gaseous, aqueous, and solid streams over the course of the SCR demonstration project;

- Section 3 summarizes sampling and analytical methods and discusses exceptions from the methods specified in the EMP;

- Section 4 presents and discusses the gas stream monitoring results;

- Section 5 presents and discusses the aqueous stream monitoring results;

- Section 6 presents and discusses the solid stream monitoring results;

- Health and safety considerations are discussed in Section 7.

- Section 8 discusses EMP-related quality assurance/quality control activities performed during the demonstration project;

- Section 9 summarizes compliance monitoring reporting activities;

- Section 10 presents a summary of results and conclusions based on the EMP monitoring results; and

- Section 11 provides a list of references. 
Tables containing the detailed results for each of the streams monitored as part of the EMP are provided in Appendix A. 


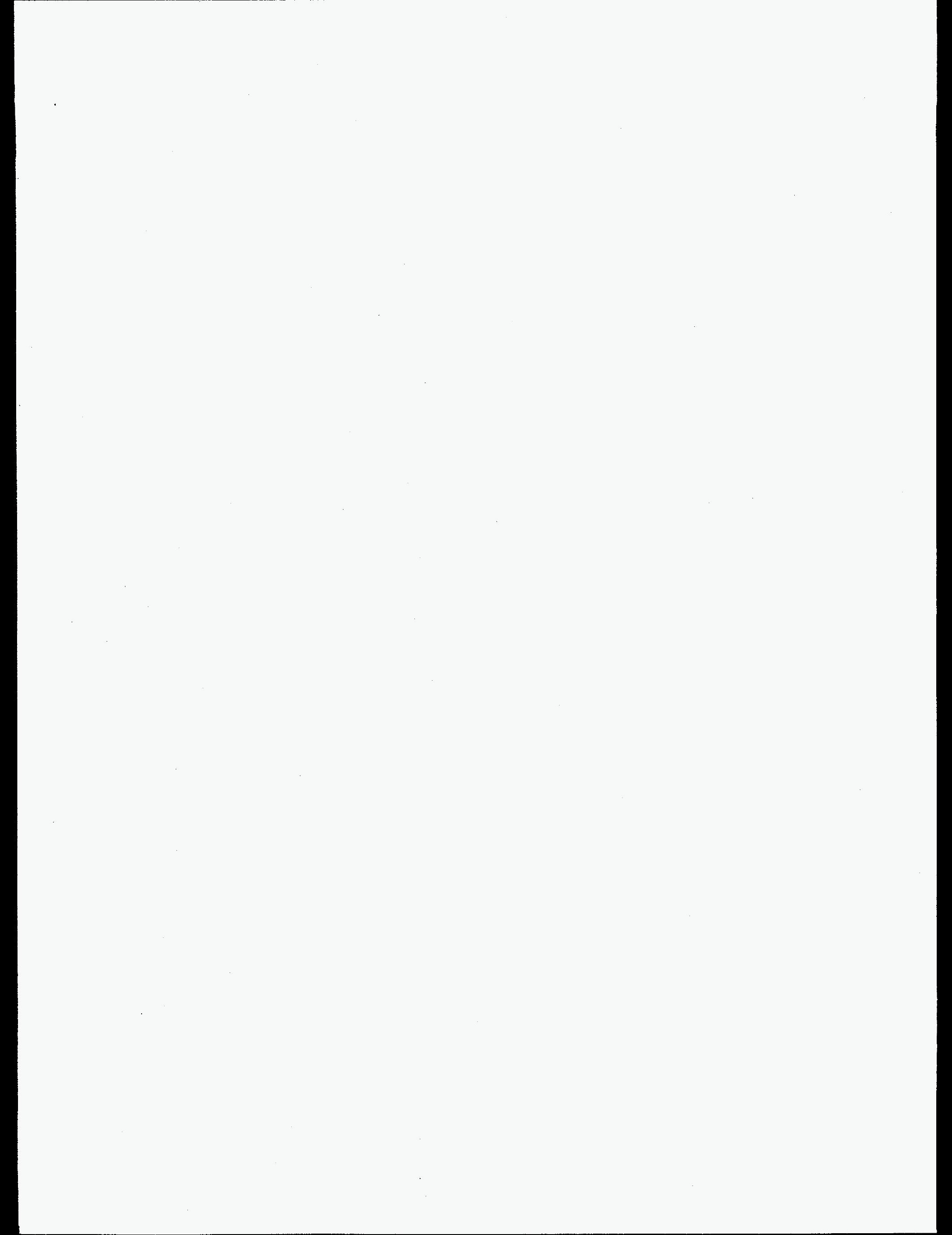




\subsection{EMP Monitoring Summary}

EMP monitoring was performed during each of the four operational and testing phase tasks described in Section 1. Table 2-1 summarizes the duration of each of the project tasks.

Key segments of the demonstration project included the five sequences of parametric tests (one during Task 3B and four during Task 4). During the parametric tests, the impacts of SCR reactor operating conditions (i.e., operating temperature, ammonia-to-nitrogen oxide flow ratio, and reactor residence time) were determined for a number of parameters, including $\mathrm{NO}_{\mathrm{x}}$ reduction, ammonia slip, and conversion of $\mathrm{SO}_{2}$ to $\mathrm{SO}_{3}$. Table 2-2 summarizes the test conditions relative to these parameters for each of the five parametric test sequences. Nitrous oxide and hydrogen chloride concentrations were also measured during tests conducted at SCR reactor baseline operating conditions (i.e., $700^{\circ} \mathrm{F}$, design flow rate, $0.8 \mathrm{NH}_{3} / \mathrm{NO}_{\mathrm{x}}$ ratio).

Tables 2-3, 2-4, and 2-5 present the planned EMP monitoring schedules for gaseous, aqueous, and solid streams, respectively. Due to time and budget constraints, a number of modifications were made to the original EMP monitoring schedule for some parameters. These changes are discussed below.

The number of gaseous stream monitoring data points collected during each of the operational and testing phase tasks (in addition to those parameters measured using continuous on-line monitors) are summarized in Table 2-6. Note that Reactor $\mathrm{J}$ was not monitored during either the startup screening tests or the first two parametric test sequences. The Reactor J catalyst was damaged just hours after initial operations began. A replacement catalyst was not installed until several months later. The supplier of catalyst for Reactor $\mathrm{H}$ withdrew from the project, and this reactor was not included in subsequent monitoring activities. Additional modifications of the original EMP monitoring schedules included the following:

- $\mathrm{SO}_{2}$ monitoring at the $\mathrm{SCR}$ reactor outlets was conducted during each of the parametric test sequences, rather than just during the initial start-up screening tests.

- $\mathrm{N}_{2} \mathrm{O}$ and $\mathrm{SO}_{3}$ monitoring at the $\mathrm{SCR}$ reactor inlets was also not limited to the start-up screening tests, but was performed during 3 of 5 parametric test sequences. 
Table 2-1. Demonstration Project Test Sequence

\begin{tabular}{|c|c|c|}
\hline Task Number & Description & Dates \\
\hline 1 & $\begin{array}{l}\text { Commissioning Without Catalysts and Without Ammonia } \\
\text { Injection: } \\
\text { - Flow calibration } \\
\text { - Particulate matter concentration and particle size } \\
\text { distribution measurements } \\
\text { - Baseline gas constituent measurements } \\
\text { - Fly ash chemical analyses } \\
\text { - Trace metals analyses }\end{array}$ & January - April 1993 \\
\hline 2 & $\begin{array}{l}\text { Commissioning Without Catalysts and With Ammonia } \\
\text { Injection: } \\
\text { - Verification of ammonia flow control } \\
\text { - Ammonia mass balance } \\
\text { - Ammonia loss in the absence of catalyst }\end{array}$ & May - June 1993 \\
\hline 3 & $\begin{array}{l}\text { 3A: Commissioning With Catalysts and Without Ammonia } \\
\text { Injection } \\
\text { - } \mathrm{SO}_{2} \text { oxidation tests* } \\
\text { 3B: Preliminary Parametric Tests (Test Sequence 1) }\end{array}$ & June- December 1993 \\
\hline 4 & $\begin{array}{l}\text { Long-Term Parametric Tests } \\
\text { - Test Sequence } 2 \\
\text { - Test Sequence } 3 \\
\text { - Test Sequence } 4 \\
\text { - Test Sequence } 5\end{array}$ & $\begin{array}{c}\text { January - April } 1994 \\
\text { June - September } 1994 \\
\text { October } 1994 \text { - January } 1995 \\
\text { May - July } 1995\end{array}$ \\
\hline
\end{tabular}

*These tests were actually performed with ammonia injection. 
Table 2-2. Plant Crist SCR Demonstration: Parametric Test Conditions

\begin{tabular}{|c|c|c|c|c|c|c|c|c|}
\hline \multirow{2}{*}{$\begin{array}{c}\text { Test } \\
\text { Condition } \\
\text { Code No. }\end{array}$} & \multicolumn{3}{|c|}{ Target Test Conditions } & \multicolumn{5}{|c|}{ Parametric Test Sequence } \\
\hline & $\begin{array}{c}\text { Flue Gas } \\
\text { Temp., }{ }^{\circ} \mathbf{F}\end{array}$ & $\begin{array}{c}\text { Flue Gas Flow Rate, } \\
\text { Fraction of Design }\end{array}$ & $\begin{array}{c}\mathrm{NH}_{3} / \mathrm{NO}_{x} \\
\text { Ratio } \\
\end{array}$ & 1 & 2 & 3 & 4 & 5 \\
\hline 1 & 620 & 0.6 & 0.6 & $\mathrm{~S}$ & $-b$ & - & - & - \\
\hline 2 & 620 & 0.6 & 0.8 & - & $\mathrm{S}$ & $\mathrm{A}$ & $\mathrm{A}, \mathrm{N}$ & $\mathrm{A}, \mathrm{N}$ \\
\hline 4 & 620 & 0.6 & 1.0 & $\mathrm{~s}$ & - & - & - & - \\
\hline 6 & 620 & 1.0 & 0.6 & - & - & $\mathrm{A}, \mathrm{N}$ & $\mathrm{A}, \mathrm{N}$ & $\mathrm{A}, \mathrm{N}$ \\
\hline 7 & 620 & 1.0 . & 0.8 & - & $\mathrm{A}$ & $\mathrm{A}, \mathrm{N}$ & $A, N$ & $\mathrm{~A}, \mathrm{~N}$ \\
\hline 9 & 620 & 1.0 & 1.0 & - & - & $\mathrm{A}, \mathrm{N}$ & $\mathrm{A}, \mathrm{N}$ & $\mathrm{A}, \mathrm{N}$ \\
\hline 11 & 620 & 1.5 & 0.6 & $\mathrm{~S}$ & - & - & - & - \\
\hline 12 & 620 & 1.5 & 0.8 & - & $\mathrm{A}$ & - & - & - \\
\hline 14 & 620 & 1.5 & 1.0 & $\mathrm{~A}, \mathrm{~S}$ & $\mathrm{~A}$ & $\mathrm{~A}, \mathrm{~N}$ & $\mathrm{~A}, \mathrm{~N}$ & $\mathrm{~A}, \mathrm{~N}$ \\
\hline 16 & 700 & 0.6 & 0.6 & A & - & - & - & - \\
\hline 17 & 700 & 0.6 & 0.8 & - & $S$ & - & - & - \\
\hline 19 & 700 & 0.6 & 1.0 & $\mathrm{~A}$ & - & - & - & - \\
\hline 21 & 700 & 1.0 & 0.6 & - & - & $\mathrm{A}, \mathrm{N}$ & $\mathrm{A}, \mathrm{N}$ & $\mathrm{A}, \mathrm{N}$ \\
\hline 22 & 700 & 1.0 & 0.8 & $\mathrm{~A}, \mathrm{~S}$ & $\mathrm{~A}, \mathrm{~S}$ & $A, N, S$ & $\mathrm{~A}, \mathrm{~N}, \mathrm{~S}$ & $\mathrm{~A}, \mathrm{~N}, \mathrm{~S}$ \\
\hline 24 & 700 & 1.0 & 1.0 & - & - & $\mathrm{A}, \mathrm{N}$ & $\mathrm{A}, \mathrm{N}$ & $\mathrm{A}, \mathrm{N}$ \\
\hline 26 & 700 & 1.5 & 0.6 & $\mathrm{~A}$ & - & $\mathrm{A}, \mathrm{N}$ & $\mathrm{A}, \mathrm{N}$ & $\mathrm{A}, \mathrm{N}$ \\
\hline 27 & 700 & 1.5 & 0.8 & - & $\mathrm{A}, \mathrm{S}$ & $\mathrm{A}, \mathrm{N}$ & $\mathrm{A}, \mathrm{N}, \mathrm{S}$ & $\mathrm{A}, \mathrm{N}$ \\
\hline 29 & 700 & 1.5 & 1.0 & - & - & $\mathrm{A}, \mathrm{N}$ & $\mathrm{A}, \mathrm{N}$ & $\mathrm{A}, \mathrm{N}$ \\
\hline 31 & 750 & 0.6 & 0.6 & $\mathrm{~S}$ & - & - & - & - \\
\hline 32 & 750 & 0.6 & 0.8 & - & $\mathrm{S}$ & - & - & - \\
\hline 34 & 750 & 0.6 & 1.0 & $\mathrm{~S}$ & - & - & - & - \\
\hline 36 & 750 & 1.0 & 0.6 & - & - & $\mathrm{A}, \mathrm{N}$ & $\mathrm{A}, \mathrm{N}$ & $\mathrm{A}, \mathrm{N}$ \\
\hline 37 & 750 & 1.0 & 0.8 & - & $\mathrm{S}$ & $\mathrm{A}, \mathrm{N}, \mathrm{S}$ & $\mathrm{A}, \mathrm{N}, \mathrm{S}$ & $\mathrm{A}, \mathrm{N}$ \\
\hline 39 & 750 & 1.0 & 1.0 & - & - & $\mathrm{A}, \mathrm{N}$ & $\mathrm{A}, \mathrm{N}$ & $\mathrm{A}, \mathrm{N}$ \\
\hline 41 & 750 & 1.5 & 0.6 & $\mathrm{~S}$ & - & - & - & - \\
\hline 42 & 750 & 1.5 & 0.8 & - & $\mathrm{S}$ & - & - & - \\
\hline 44 & 750 & 1.5 & 1.0 & $S$ & - & - & $=$ & $=$ \\
\hline
\end{tabular}

Key: $\quad \mathrm{A}=\mathrm{NH}_{3}$ slip

$\mathrm{N}=\mathrm{NO}_{\mathrm{x}}$ reduction

$\mathrm{S}=\mathrm{SO}_{2} / \mathrm{SO}_{3}$

${ }^{a}$ Code indicates test conditions, not test sequence.

${ }^{B}$ Dash indicates that test was not scheduled or performed. 


\section{Table 2-3. Gaseous Streams: Integrated Monitoring Schedule SCR Demonstration Project (Revised)}

\begin{tabular}{|c|c|c|c|}
\hline \multirow[b]{2}{*}{ Parameter } & \multicolumn{3}{|c|}{ Monitoring Schedule ${ }^{2, b}$} \\
\hline & $\begin{array}{c}\text { SCR Inlet Gas } \\
\text { (common to all reactors) }\end{array}$ & $\begin{array}{l}\text { SCR Outlet Gas } \\
\text { (for each reactor) }\end{array}$ & Air Preheater Outlet Gas \\
\hline $\mathrm{SO}_{2}$ & $\mathrm{COM}$ & $\mathrm{T}$ & \\
\hline $\mathrm{CO}$ & COM & & \\
\hline $\mathrm{N}_{2} \mathrm{O}$ & $\mathrm{T}$ & $\mathrm{T}$ & \\
\hline $\mathrm{NO}_{x}$ & $\mathrm{COM}$ & $\mathrm{COM}^{*}$ & \\
\hline $\mathrm{O}_{2}$ & $\mathrm{COM}$ & $\mathrm{COM}$ & $\mathrm{COM}^{\mathrm{c}}$ \\
\hline $\mathrm{SO}_{3}$ & S & $\mathrm{T}$ & \\
\hline $\mathrm{NH}_{3}$ & $T$ & $\mathrm{~T}$ & \\
\hline $\mathrm{HCl}$ & $\mathrm{s}$ & $T$ & \\
\hline \multicolumn{4}{|l|}{ Particulate Matter: } \\
\hline Loading & S & $\mathrm{P}^{* *}$ & \\
\hline Size Distribution & S & $\mathbf{P}^{* *}$ & \\
\hline Composition $^{d}$ & $S$ & $\mathrm{P}^{* *}$ & \\
\hline TCLP ${ }^{e}$ & $\begin{array}{c}\mathrm{P}^{* * *} \\
\text { (composite grab sample } \\
\text { from ESP hopper) }\end{array}$ & $\begin{array}{c}\mathrm{P}^{* * *} \\
\text { (composite grab sample from } \\
5 \text { small reactor cyclones) }\end{array}$ & $\begin{array}{c}\mathrm{P}^{* * *} \\
\text { (composite grab sample from } \\
3 \text { large reactor cyclones) }\end{array}$ \\
\hline
\end{tabular}

${ }^{a}$ Monitoring frequency: $\mathrm{T}$ = one time per parametric test and one time during initial start-up screening tests (for $\mathrm{NH}_{3}$ and $\mathrm{SO}_{3}$, samples will be collected in duplicate and analyzed in triplicate); $\mathrm{S}=$ one time during start-up screening tests; and $\mathrm{P}=$ periodically during the project.

${ }^{\mathrm{b}}$ Some of these data will be available from process data collection.

${ }^{\circ} \mathrm{O}_{2}$ was not measured at the Reactor $\mathrm{C}$ air preheater outlet since no inleakage was expected across the heat pipe.

'Includes ash mineral analysis (iron, aluminum, silicon, calcium, magnesium, sodium, potassium, and titanium), ammonium bisulfate, chloride, and metals.

${ }^{\mathrm{e}}$ For TCLP determination, all reactors were sampled at their respective ash hoppers. On the large reactors, this was done downstream of the air preheater.

$\mathrm{COM}=$ Continuous on-line monitor

* Monitored continuously on a time-share basis.

**Estimated semi-annual basis.

***One time during initial screening test, annually thereafter.

[All monitoring shown is supplemental.] 
Table 2-4. Aqueous Streams: Integrated Monitoring Schedule SCR Demonstration Project

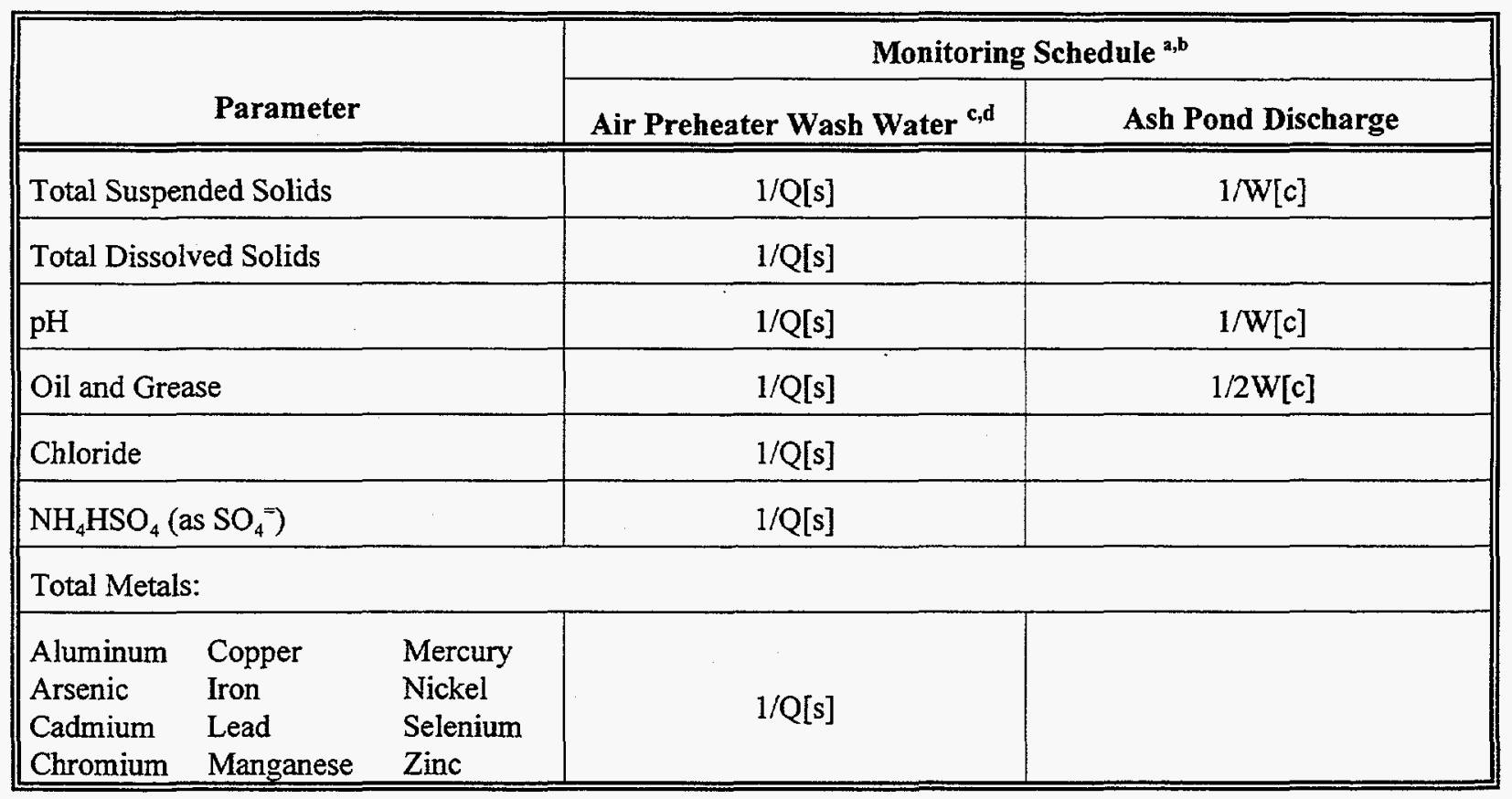

${ }^{\mathrm{a}}$ Monitoring frequency: $1 / \mathrm{W}=$ once per week; $1 / 2 \mathrm{~W}=$ once every two weeks; and $1 / \mathrm{Q}=$ once per calendar quarter.

${ }^{b}$ Letter within brackets indicates monitoring type: $[c]=$ compliance monitoring and $[s]=$ supplemental monitoring for duration of SCR demonstration project only.

${ }^{\mathrm{c}}$ Refers only to the air preheater wash that is associated with the demonstration unit.

${ }^{d}$ Wash water will be monitored during each wash cycle, up to four times per year. The actual sampling frequency will depend on the required washing frequency. 
Table 2-5. Solid Streams: Integrated Monitoring Schedule SCR Demonstration Project

\begin{tabular}{|l|c|}
\hline \multicolumn{1}{|c|}{ Parameter } & $\begin{array}{c}\text { Monitoring Schedule }{ }^{\text {a, }} \\
\text { Coal Feed }\end{array}$ \\
\hline \hline Ultimate Analysis & $1 / \mathrm{Q}[\mathrm{s}]$ \\
\hline Chlorine & $1 / \mathrm{Q}[\mathrm{s}]$ \\
\hline
\end{tabular}

${ }^{\mathrm{a}}$ Monitoring frequency: $1 / \mathrm{Q}=$ once per quarter.

${ }^{\mathrm{b}}$ Letter within brackets indicates monitoring type: [s] = supplemental monitoring for duration of SCR demonstration project. 
Table 2-6. Gaseous Stream Monitoring Summary: Number of Data Points Collected for Non-Continuous Parameters

\begin{tabular}{|c|c|c|c|c|c|c|c|c|c|c|}
\hline \multirow[b]{2}{*}{ Monitored Parameter } & \multicolumn{10}{|c|}{ Monitoring Location-SCR Reactor } \\
\hline & $\begin{array}{l}\text { ESP } \\
\text { Inlet }\end{array}$ & $\mathbf{A}$ & B & $\mathrm{C}$ & $\mathbf{D}$ & $\mathbf{E}$ & $\mathbf{F}$ & $\mathbf{G}$ & $\mathbf{H}$ & $\mathbf{J}$ \\
\hline \multicolumn{11}{|c|}{ Startup Screening Tests (Tasks $1-3 \mathrm{~A}$ ) } \\
\hline $\mathrm{SO}_{2} / \mathrm{SO}_{3}$ (Oxidation Tests) & $一^{\mathbf{a}}$ & 9 & 11 & 15 & - & - & - & - & - & - \\
\hline $\mathrm{NH}_{3}$ (Loss Tests) & - & - & 4 & - & - & 4 & - & - & - & - \\
\hline PM Loading & 2 & 2 & 2 & 2 & 2 & 2 & 2 & 2 & 2 & - \\
\hline PM Size Distribution & 2 & 2 & 2 & 2 & 2 & 2 & 2 & 2 & 2 & - \\
\hline PM Composition & 2 & 1 & 1 & - & - & - & - & 一 & - & 一 \\
\hline TCLP & 1 & 2 & 2 & 2 & 1 & 1 & 1 & 1 & 1 & - \\
\hline \multicolumn{11}{|l|}{ Parametric Test Sequence 1} \\
\hline $\mathrm{NH}_{3}$ (Inlet \& Outlet) & - & 5 & 6 & 7 & 2 & 2 & 2 & 一 & - & 一 \\
\hline $\mathrm{SO}_{2} / \mathrm{SO}_{3}$ (Outlet) & - & 9 & 9 & 9 & 5 & 5 & 5 & - & 一 & 一 \\
\hline $\mathrm{HCl}$ (Outlet) & - & 1 & 1 & 3 & 1 & 1 & 1 & - & - & 一 \\
\hline $\mathrm{N}_{2} \mathrm{O}$ (Inlet \& Outlet) & - & 0 & 0 & 0 & 0 & 0 & 0 & - & - & - \\
\hline \multicolumn{11}{|l|}{ Parametric Test Sequence 2} \\
\hline $\mathrm{NH}_{3}$ (Inlet \& Outlet) & - & 8 & 8 & 7 & 7 & 8 & 8 & 6 & - & 一 \\
\hline $\mathrm{SO}_{2} / \mathrm{SO}_{3}$ (Outlet) & - & 7 & 7 & 7 & 7 & 7 & 7 & 7 & 一 & 一 \\
\hline $\mathrm{HCl}$ (Outlet) & - & 1 & 1 & 1 & 1 & 1 & 1 & 1 & - & 一 \\
\hline $\mathrm{N}_{2} \mathrm{O}$ (Inlet \& Outlet) & - & 1 & 1 & 1 & 1 & 1 & 1 & 1 & - & - \\
\hline \multicolumn{11}{|l|}{ Parametric Test Sequence 3} \\
\hline $\mathrm{NO}_{x}$ (Inlet \& Outlet) & 一 & 9 & 14 & 9 & 17 & 14 & 17 & 14 & - & 11 \\
\hline $\mathrm{NH}_{3}$ (Inlet \& Outlet) & - & 14 & 14 & 14 & 17 & 14 & 17 & 14 & - & 11 \\
\hline $\mathrm{SO}_{2} / \mathrm{SO}_{3}$ (Inlet \& Outlet) & - & 2 & 2 & 2 & 2 & 2 & 2 & 2 & - & 1 \\
\hline $\mathrm{HCl}$ (Outlet) & - & 1 & 1 & 1 & 1 & 1 & 1 & 1 & - & 1 \\
\hline $\mathrm{N}_{2} \mathrm{O}$ (Inlet \& Outlet) & - & 0 & 0 & 0 & 0 & 0 & 0 & 0 & 一 & 0 \\
\hline \multicolumn{11}{|l|}{ Parametric Test Sequence 4} \\
\hline $\mathrm{NO}_{\mathrm{x}}$ (Inlet \& Outlet) & - & 14 & 14 & 12 & 14 & 15 & 15 & 14 & - & 14 \\
\hline $\mathrm{NH}_{3}$ (Inlet \& Outlet) & - & 14 & 14 & 14 & 14 & 15 & 15 & 14 & - & 11 \\
\hline $\mathrm{SO}_{2} / \mathrm{SO}_{3}$ (Inlet \& Outlet) & - & 3 & 3 & 3 & 3 & 3 & 3 & 3 & - & 3 \\
\hline $\mathrm{HCl}$ (Inlet \& Outlet) & - & 1 & 1 & 1 & 1 & 1 & 1 & 1 & - & 1 \\
\hline $\mathrm{N}_{2} \mathrm{O}$ (Inlet \& Outlet) & - & 1 & 1 & 1 & 1 & 1 & 1 & 1 & - & 1 \\
\hline
\end{tabular}


Table 2-6 (continued)

\begin{tabular}{|c|c|c|c|c|c|c|c|c|c|c|}
\hline \multirow[b]{2}{*}{ Monitored Parameter } & \multicolumn{10}{|c|}{ Monitoring Location-SCR Reactor } \\
\hline & $\begin{array}{l}\text { ESP } \\
\text { Inlet }\end{array}$ & A & $\mathbf{B}$ & $\mathbf{C}$ & $\mathbf{D}$ & $\mathbf{E}$ & $\mathbf{F}$ & $\mathbf{G}$ & $\mathbf{H}$ & $\mathbf{J}$ \\
\hline \multicolumn{11}{|l|}{ Parametric Test Sequence 5} \\
\hline $\mathrm{NO}_{\mathrm{x}}$ (Inlet \& Outlet) & - & 14 & 15 & 14 & 14 & 14 & 14 & 14 & - & 14 \\
\hline $\mathrm{NH}_{3}$ (Inlet \& Outlet) & - & 14 & 15 & 14 & 14 & 14 & 14 & 14 & - & 14 \\
\hline $\mathrm{SO}_{2} / \mathrm{SO}_{3}$ (Inlet \& Outlet) & - & 1 & 1 & 1 & 1 & 1 & 1 & 1 & - & 1 \\
\hline $\mathrm{HCl}$ (Inlet \& Outlet) & - & 1 & - & 一 & - & 一 & - & - & - & - \\
\hline $\mathrm{N}_{2} \mathrm{O}$ (Inlet \& Outlet) & - & 1 & 1 & 1 & 1 & 1 & 1 & 1 & - & 1 \\
\hline \multicolumn{11}{|c|}{ Periodic Monitoring (following start-up screening tests) } \\
\hline PM Loading & - & 3 & 4 & 3 & 3 & 3 & 3 & 1 & - & - \\
\hline Ash Composition & 一 & 1 & 1 & 1 & - & - & - & - & 一 & - \\
\hline TCLP & 2 & 2 & 2 & 2 & 2 & 2 & 2 & 2 & 1 & - \\
\hline
\end{tabular}

${ }^{\mathrm{a}}$ Dash indicates that test was not scheduled or performed. 
- $\mathrm{HCl}$ monitoring at the SCR reactor inlets was performed during one of the parametric test sequences for all operating reactors and for one reactor during another test sequence.

- In addition to the data provided by continuous on-line monitors, reactor inlet and outlet stream samples were collected and analyzed for $\mathrm{SO}_{2}$ and $\mathrm{NO}_{\mathrm{x}}$.

Particulate matter (PM) loading, composition, and size distribution were measured less frequently than shown in the EMP. Particulate matter size distributions were only measured during initial screening tests (at two boiler load levels). Loading and composition were conducted throughout the testing phase, but somewhat less frequently than the estimated semi-annual basis shown in the EMP.

Aqueous stream compliance monitoring was conducted for the ash pond discharge at the frequencies required by Plant Crist's discharge permit. Analytical results of air preheater wash water were only available from one wash cycle, and only a limited suite of parameters were measured, including $\mathrm{pH}$, iron, fluoride, chloride, and sulfate.

Ultimate analyses and chlorine content were obtained using monthly coal feed composite samples rather than quarterly composites as shown in the EMP. 



\subsection{Sampling and Analytical Methods}

The sampling and analytical methods used in implementing the environmental monitoring program at Plant Crist are summarized in this section of the report. Descriptions of the sampling and analytical methods were provided in the QA/QC Plan developed as part of the project EMP (1).

\subsection{Sampling Methods}

The sampling methods used during the environmental monitoring activities are summarized in Tables 3-1, 3-2, and 3-3. There were no changes from the planned methods as outlined in the EMP.

\subsection{Analytical Methods}

Analytical methods used in analyzing environmental samples are listed in Tables 3-1, 3-2, and 3-3. The methods presented in the EMP were used with the following exceptions:

- A non-dispersive type IR analyzer was used for $\mathrm{CO}$ analyses, not a "Fuji CO analyzer."

- The $\mathrm{NO}_{\mathrm{x}}$ analyzer was a chemiluminescence analyzer but not "TECO."

- Oxygen was measured using a zirconium oxide cell, not a "Thermox $\mathrm{O}_{2}$ analyzer."

In the original proposal, the Fuji $\mathrm{CO}$ analyzer, the TECO analyzer, and the Thermox $\mathrm{O}_{2}$ analyzer were proposed as examples of instruments that would provide the required analyses. During the design stage of the project, however, the project analytical requirements were reviewed in a very thorough manner. As a result, the alternate instruments listed above were selected as the best methods for the required analyses.

Other exceptions include:

- $\mathrm{SO}_{3}, \mathrm{HCl}$, and $\mathrm{NH}_{3}$ were measured in the $\mathrm{SCR}$ reactor air preheater outlet steams, in addition to the $\mathrm{SCR}$ reactor inlet and outlet streams.

- $\mathrm{O}_{2}$ was measured in the air preheater outlet of Reactors $\mathrm{A}$ and $\mathrm{B}$, but not that following Reactor $\mathrm{C}$, which used a heat pipe for which no air inleakage was expected. 


\section{Table 3-1. Sampling and Analytical Methods Summary: Gaseous Streams (Revised 7/1/96)}

\begin{tabular}{|c|c|c|c|}
\hline Parameter & Sampling Method & Analytical Method/Instrument & Streams Included ${ }^{2}$ \\
\hline $\mathrm{SO}_{2}$ & GAS $^{b}$ & UV Spectrophotometer & $\mathbf{a}$ \\
\hline $\mathrm{CO}$ & GAS & Non-dispersive IR Analyzer & a \\
\hline $\mathrm{N}_{2} \mathrm{O}$ & $\mathrm{Grab}^{\mathrm{c}}$ & $\mathrm{GC}$ w/ECD & $\mathrm{a}, \mathrm{b}$ \\
\hline $\mathrm{NO}_{\mathrm{x}}$ & GAS & Chemiluminescence Analyzer & $a, b$ \\
\hline $\mathrm{O}_{2}$ & GAS & Zirconium Oxide Cell & $a, b, c$ \\
\hline $\mathrm{SO}_{3}$ & $\begin{array}{l}\text { Controlled } \\
\text { Condensation }\end{array}$ & Impinger, $I^{d}$ & $a, b, c$ \\
\hline $\mathrm{HCl}$ & Impinger & Impinger, ISE $/ \mathrm{IC}^{d}$ & $a, b, c$ \\
\hline $\mathrm{NH}_{3}$ & Impinger & Impinger, ISE $^{\mathrm{e}}$ & $a, b, c$ \\
\hline \multicolumn{4}{|l|}{ Particulate Matter: } \\
\hline Loading & EPA Method 17 & Gravimetric & $a, b$ \\
\hline Size Distribution & Impactors/Cyclones $^{\mathrm{f}}$ & Gravimetric & $a, b$ \\
\hline Composition: & Method 17 Catch & & $a, b$ \\
\hline Ash Minerals & & $\begin{array}{l}\text { Fusion, dissolution, AA/ICP- } \\
\text { AES (ASTM D3682) }\end{array}$ & \\
\hline $\mathrm{NH}_{4} \mathrm{HSO}_{4}$ & & $\mathrm{X}$-ray diffraction & \\
\hline Chloride & & $\begin{array}{l}\text { Digestion, Ion Chromatography } \\
\text { (EPA 300.0) }\end{array}$ & \\
\hline Metals & & $\begin{array}{l}\text { Digestion, AA/ICP-AES } \\
\text { (EPA 206.3, 213.2, 239.2, 245.1, } \\
270.3,200.7 \text { ) }\end{array}$ & \\
\hline TCLP & & $\begin{array}{l}\text { Leaching, GC and AA/ICP-AES } \\
\text { (EPA 1311) }\end{array}$ & \\
\hline
\end{tabular}

${ }^{a}$ Stream Identification: $a=$ SCR reactor inlet (common to all high-dust reactors); $b=$ SCR reactor outlet (for each reactor); and $\mathrm{c}=$ air preheater outlet (for each reactor for $\mathrm{SO}_{3}, \mathrm{HCl}$, and $\mathrm{NH}_{3}$; Reactors $\mathrm{A}$ and $\mathrm{B}$ for $\mathrm{O}_{2}$ ).

${ }^{b} \mathrm{GAS}=$ Extractive gas analysis system

${ }^{c} \mathrm{Grab}$ sample for $\mathrm{N}_{2} \mathrm{O}$ determination was carefully conditioned by passing through phosphorus pentoxide (to remove water) and sodium bicarbonate (to remove $\mathrm{SO}_{2}$ ).

${ }^{\mathrm{d}} \mathrm{IC}=$ Ion chromatography.

' ISE = Ion specific electrode.

${ }^{\mathrm{f}} \mathrm{A}=$ Shimadzu and University of Washington cascade impactors and five-stage cyclones. 
Table 3-2. Sampling and Analytical Methods: Aqueous Streams (Revised 12/9/92)

\begin{tabular}{|c|c|c|c|}
\hline Parameter & $\begin{array}{l}\text { Sampling } \\
\text { Method }\end{array}$ & Analytical Method & Streams Included $^{2}$ \\
\hline Total Suspended Solids & Grab & $\begin{array}{l}\text { Filtration/Drying/Gravimetric } \\
\text { (EPA 160.2) }\end{array}$ & a, w \\
\hline Total Dissolved Solids & Grab & $\begin{array}{l}\text { Filtration/Evaporation/Gravimetric } \\
\text { (EPA 160.1) }\end{array}$ & w \\
\hline $\mathrm{pH}$ & Grab & Electrometric (EPA 150.1) & a \\
\hline Oil and Grease & Grab & $\begin{array}{l}\text { Freon Extraction/Gravimetric } \\
\text { (EPA 413.1) }\end{array}$ & a \\
\hline Chloride & Grab & Titration (EPA 325.3) & $\mathbf{w}$ \\
\hline $\begin{array}{l}\text { Ammonium Bisulfate (as } \\
\mathrm{SO}_{4}{ }^{-} \text {) }\end{array}$ & Grab & Ion Chromatography (EPA 300.0) & $\mathrm{w}$ \\
\hline Metals & Grab & $\begin{array}{l}\text { Dissolution, AA/ICP-AES }{ }^{b} \\
\text { (EPA 206.3, 213.2, 239.2, 245.1, } \\
270.3,200.7 \text { ) }\end{array}$ & w \\
\hline
\end{tabular}

${ }^{a}$ Stream identification: $a=$ ash pond discharge and $\mathrm{w}=$ air preheater wash water.

${ }^{b}$ Analytical methods: $\mathrm{AA}=$ atomic absorption and ICP-AES $=$ inductively coupled plasma argon emission spectroscopy.

Table 3-3. Sampling and Analytical Methods: Solid Streams (Revised 7/1/96)

\begin{tabular}{|l|c|l|c|}
\hline \multicolumn{1}{|c|}{ Parameter } & Sampling Method & \multicolumn{1}{|c|}{ Analytical Method } & Streams Included $^{\mathrm{a}}$ \\
\hline \hline Ultimate Analysis & Grab/Composite & $\begin{array}{l}\text { Combustion/Gravimetric/ } \\
\text { Titration (ASTM D3180) }\end{array}$ & $\mathrm{f}$ \\
\hline Chlorine & Grab/Composite & $\begin{array}{l}\text { Fusion/IC }{ }^{\mathrm{b}} \text { or Titration } \\
\text { (ASTM D4208) }\end{array}$ & $\mathrm{f}$ \\
\hline
\end{tabular}

${ }^{a}$ Stream identification: $f=$ coal feed.

${ }^{\mathrm{b}} \mathrm{IC}=$ Ion chromatography. 
- ASTM methods other than those shown in the EMP were used for the feed coal analyses: ASTM D3180 was used for ultimate analyses, while ASTM D4208 was used for the determination of chlorine concentration.

These alternate methods were equivalent or superior to the methods listed in the EMP (1). 


\subsection{Gaseous Stream Monitoring Results}

Gaseous stream monitoring results are summarized and discussed in this section of the report. The results of parametric and long-term monitoring are discussed separately. Tables containing the detailed monitoring data are provided in Appendix A. The data were taken from Southern Company Services' final report (2) and Southern Research Institute's (SRI) interim reports $(3,4,5,6,7,8,9,10)$.

\subsection{Parametric Test Results}

The impacts of SCR reactor operating conditions on flue gas constituents were investigated during the five parametric test sequences that were conducted over the course of the demonstration program. This section discusses the monitoring results for nitrogen oxides, ammonia, sulfur oxides, nitrous oxide, hydrogen chloride, and particulate matter.

\subsubsection{Nitrogen Oxides $\left(\mathrm{NO}_{\mathrm{x}}\right)$}

$\mathrm{NO}_{\mathrm{x}}$ reductions achieved by each of the SCR reactors were calculated using SRI test data from parametric test sequences 3,4 , and 5 , for which both reactor inlet and outlet $\mathrm{NO}_{\mathrm{x}}$ concentrations were available in SRI's interim reports. A summary of the mean apparent $\mathrm{NO}_{\mathrm{x}}$ reductions measured during the parametric testing is presented in Table 4-1. The $\mathrm{NO}_{\mathrm{x}}$ reductions shown have not been corrected for factors such as oxygen in-leakage and, therefore, do not match exactly the data used for evaluating catalyst performance or corrected data shown in the project quarterly and final reports. Also note that in some cases the actual reactor operating conditions varied significantly from the target conditions shown in Table 4-1.

Figures 4-1 through 4-6 are plots of apparent $\mathrm{NO}_{\mathrm{x}}$ reduction showing the effects of reactor operating temperature, $\mathrm{NH}_{3} / \mathrm{NO}_{\mathrm{x}}$ ratio, and gas residence time (which is inversely proportional to gas flow rate). These figures are based on the mean $\mathrm{NO}_{\mathrm{x}}$ removals when replicate tests were conducted for a given set of operating conditions. In general, changes to the major SCR reactor operating parameters had the following impacts:

- Increasing the $\mathrm{NH}_{3} / \mathrm{NO}_{\mathrm{x}}$ ratio increased $\mathrm{NO}_{\mathrm{x}}$ reduction efficiency;

- Increasing reactor residence time (i.e., reducing gas throughput) increased $\mathrm{NO}_{\mathrm{x}}$ reduction efficiency; and 
Table 4-1. SCR Reactor Mean Apparent $\mathrm{NO}_{x}$ Reductions Across SCR Reactors During Parametric Tests

\begin{tabular}{|c|c|c|c|c|c|c|c|c|c|c|c|}
\hline \multicolumn{4}{|c|}{ Target Reactor Operating Conditions } & \multirow{2}{*}{\multicolumn{8}{|c|}{$\begin{array}{c}\text { Mean Apparent NO }{ }_{x} \text { Reduction, Percent } \\
\text { Reactor ID }\end{array}$}} \\
\hline \multirow{2}{*}{$\begin{array}{c}\text { Test } \\
\text { Condition }\end{array}$} & \multirow{2}{*}{$\underset{{ }^{\circ} \mathbf{F}}{\text { Temp., }}$} & \multirow{2}{*}{$\begin{array}{c}\text { Gas Flow/ } \\
\text { Design Flow }\end{array}$} & \multirow[b]{2}{*}{$\mathrm{NH}_{3} / \mathrm{NO}_{\mathbf{x}}$} & & & & & & & & \\
\hline & & & & $\mathbf{A}$ & B & $\mathbf{C}$ & D & $\mathbf{E}$ & $\mathbf{F}$ & $\mathbf{G}$ & $\mathbf{J}$ \\
\hline 2 & 620 & 0.6 & 0.8 & 79.1 & 84.2 & 93.3 & 96.7 & 80.0 & 96.0 & 82.5 & 61.5 \\
\hline 6 & 620 & 1.0 & 0.6 & 71.2 & 68.6 & 82.6 & 84.6 & 62.0 & 76.0 & 66.3 & 51.2 \\
\hline 7 & 620 & 1.0 & 0.8 & 84.5 & 87.3 & 95.3 & 91.2 & 75.9 & 87.3 & 84.1 & 67.6 \\
\hline 9 & 620 & 1.0 & 1.0 & 94.1 & 99.2 & 99.1 & 92.0 & 87.5 & 92.1 & 84.1 & 76.4 \\
\hline 14 & 620 & 1.5 & 1.0 & 89.8 & 97.5 & 96.0 & 85.5 & 89.9 & 90.6 & 85.1 & 77.8 \\
\hline 21 & 700 & 1.0 & 0.6 & 71.6 & 69.0 & 70.5 & 82.7 & 74.1 & 77.5 & 67.7 & 56.0 \\
\hline 22 & 700 & 1.0 & 0.8 & 80.8 & 87.3 & 88.8 & 92.3 & 84.5 & 82.9 & 82.4 & 65.6 \\
\hline 24 & 700 & 1.0 & 1.0 & 88.7 & 99.8 & 98.3 & 94.7 & 93.9 & 91.7 & 85.7 & 85.7 \\
\hline 26 & 700 & 1.5 & 0.6 & 64.8 & 66.9 & 69.5 & 81.3 & 71.7 & 70.6 & 65.3 & 55.9 \\
\hline 27 & 700 & 1.5 & 0.8 & 71.0 & 77.2 & 89.6 & 89.6 & 84.3 & 81.0 & 77.4 & 70.6 \\
\hline 29 & 700 & 1.5 & 1.0 & 90.9 & 96.0 & 99.2 & 92.4 & 92.9 & 89.6 & 88.8 & 85.4 \\
\hline 36 & 750 & 1.0 & 0.6 & 61.8 & 69.2 & 72.9 & 80.9 & 72.1 & 73.6 & 64.3 & 58.0 \\
\hline 37 & 750 & 1.0 & 0.8 & 79.6 & 83.3 & 92.0 & 88.7 & 85.0 & 83.2 & 74.0 & 67.6 \\
\hline 39 & 750 & 1.0 & 1.0 & 90.5 & 97.1 & 96.8 & 94.6 & 89.2 & 94.3 & 87.1 & 82.2 \\
\hline
\end{tabular}




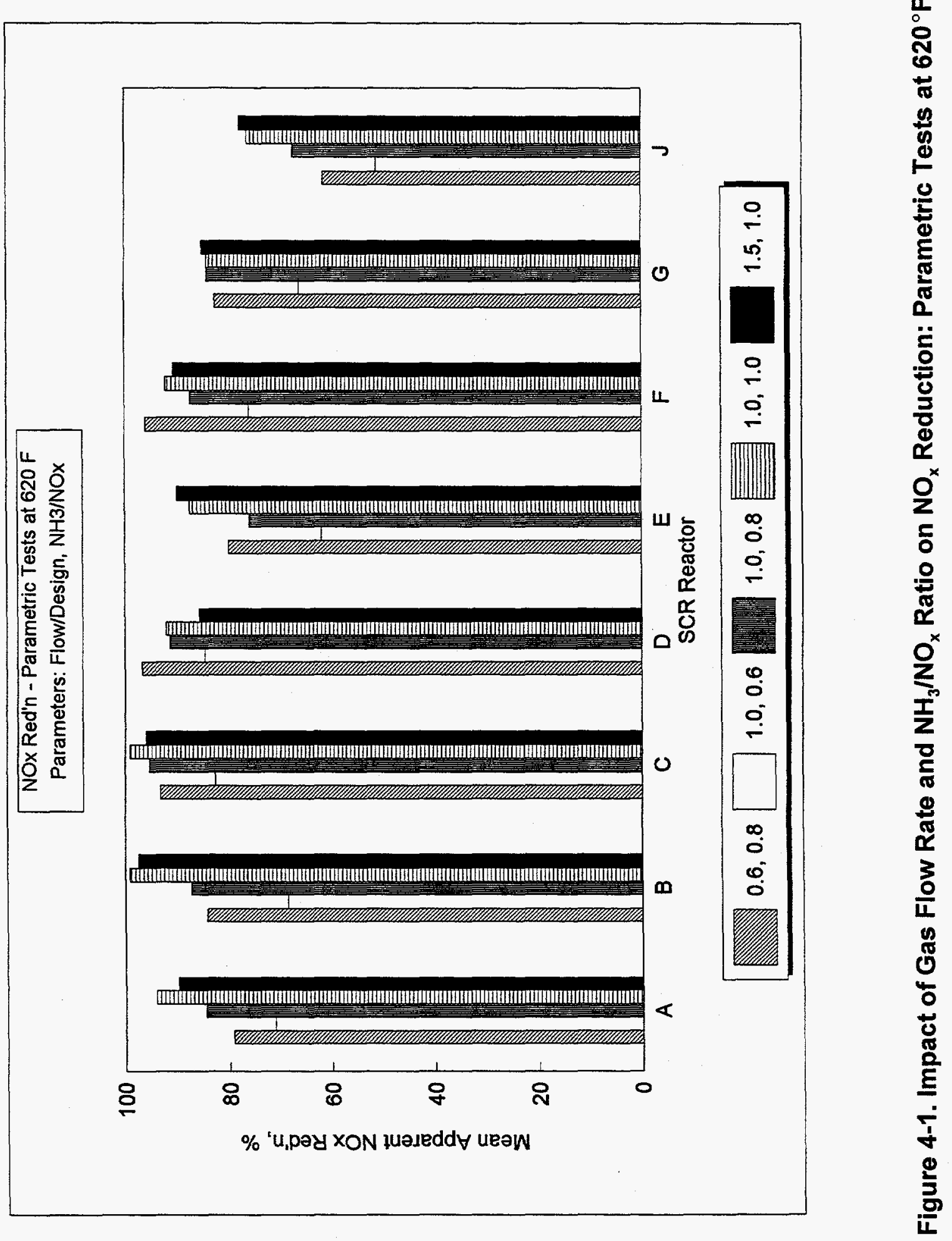




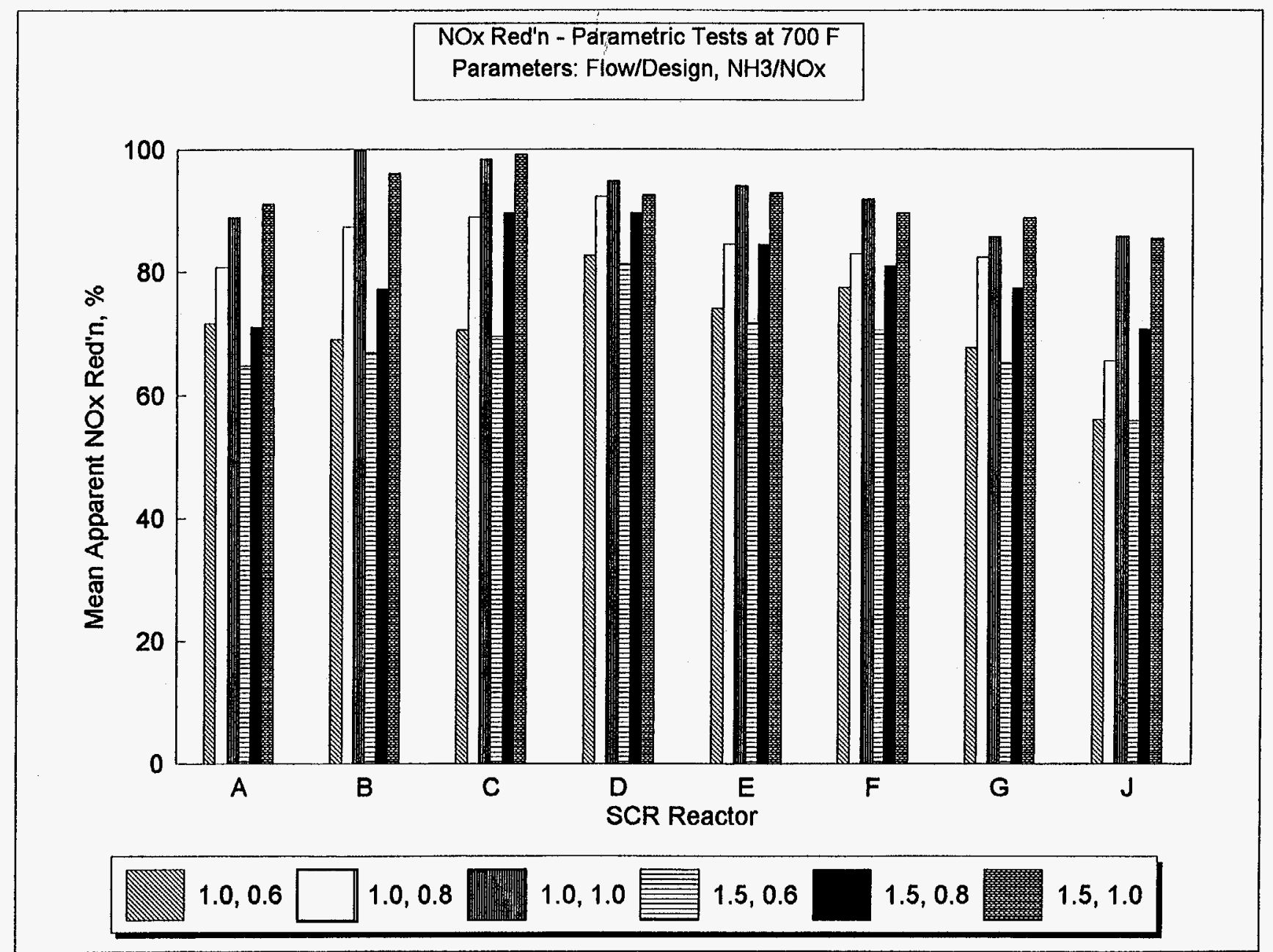

Figure 4-2. Impact of Gas Flow Rate and $\mathrm{NH}_{3} / \mathrm{NO}_{x}$ Ratio on $\mathrm{NO}_{x}$ Reduction: Parametric Tests at $700^{\circ} \mathrm{F}$ 


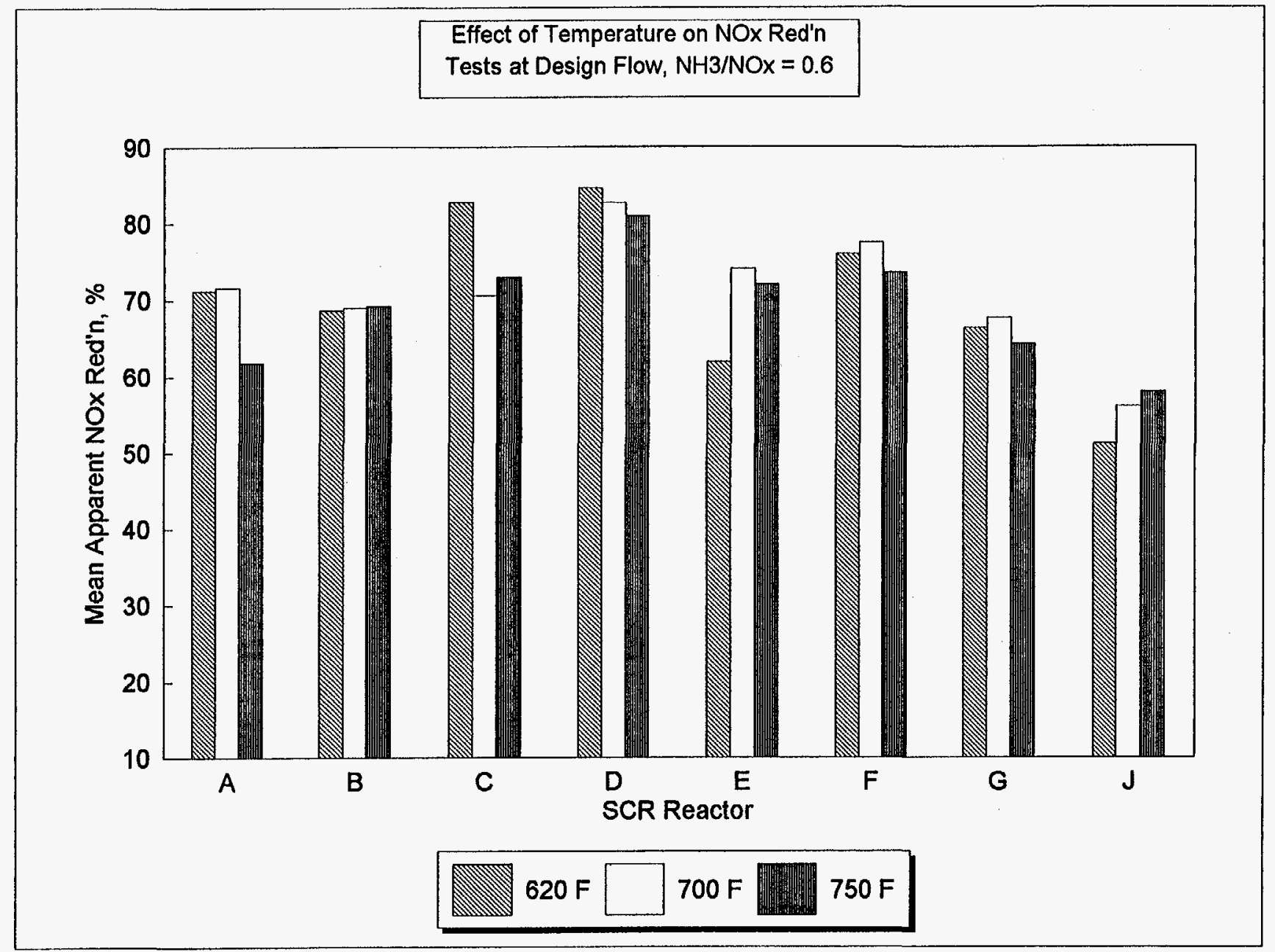

Figure 4-4. Impact of Reactor Operating Temperature on $\mathrm{NO}_{x}$ Reduction: Parametric Tests at Design Flow Rate and $\mathrm{NH}_{3} / \mathrm{NO}_{x}$ Ratio $=0.6$ 


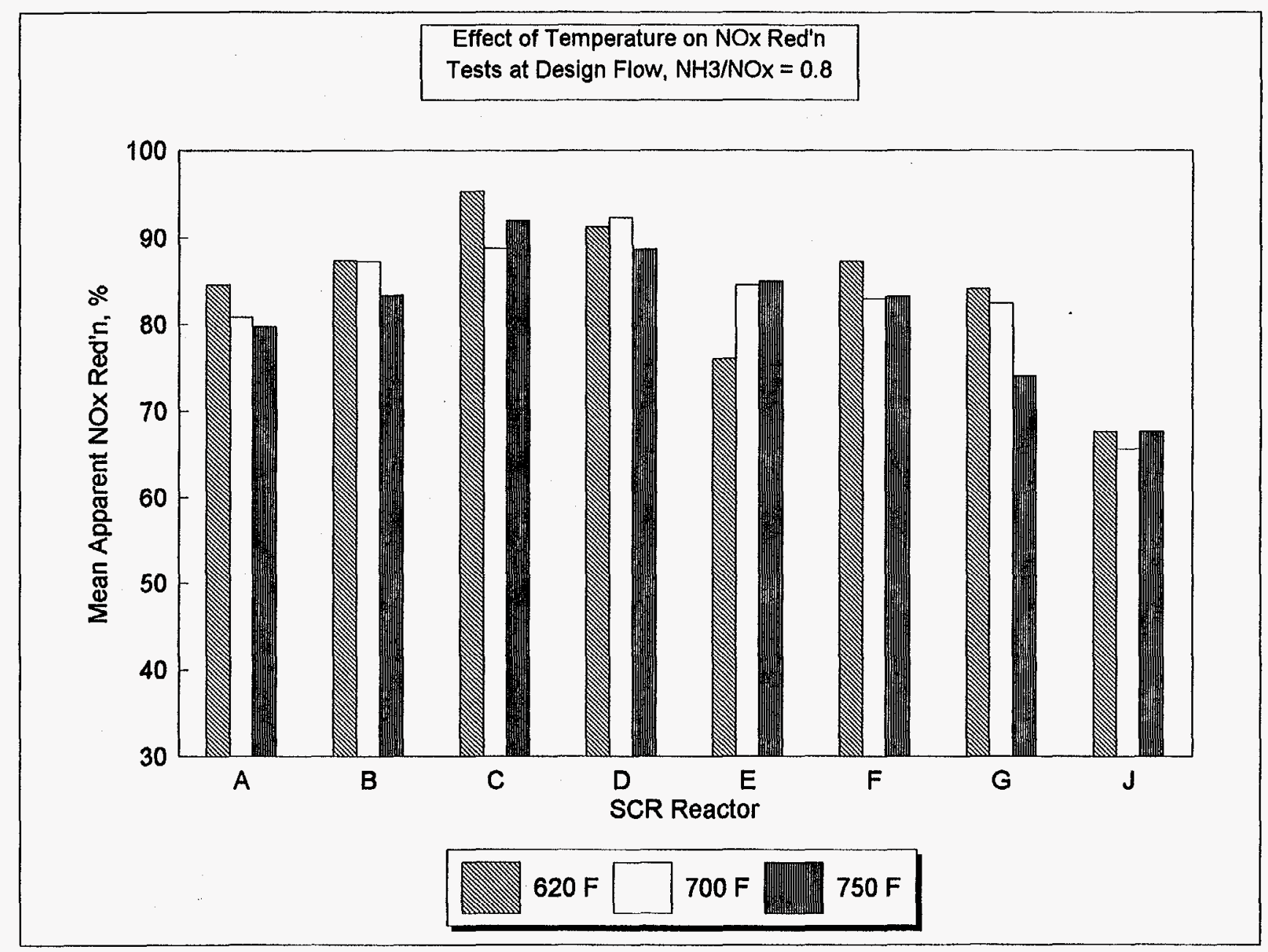

Figure 4-5. Impact of Reactor Operating Temperature on $\mathrm{NO}_{x}$ Reduction: Parametric Tests at Design Flow Rate and $\mathrm{NH}_{3} / \mathrm{NO}_{x}$ Ratio $=0.8$ 


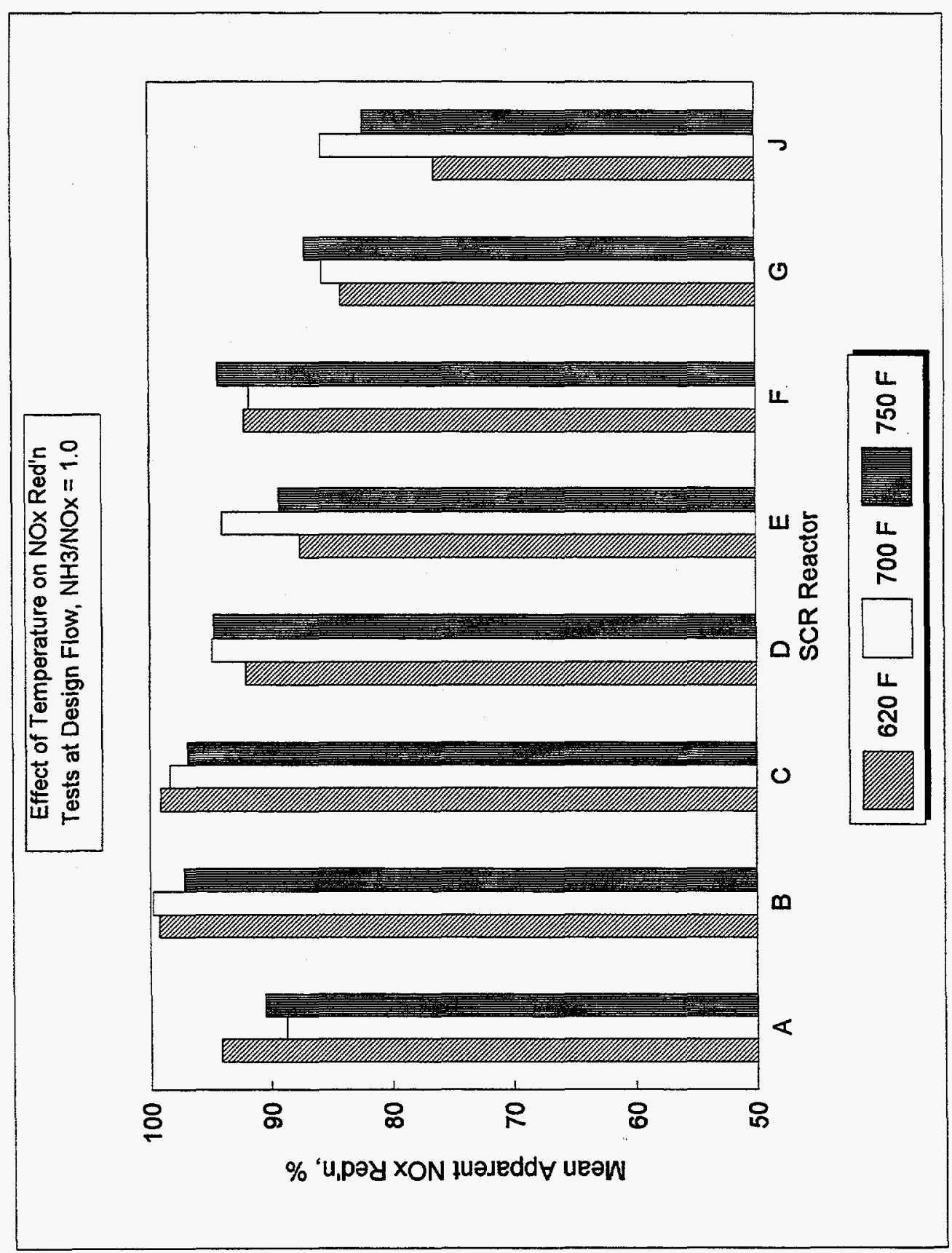

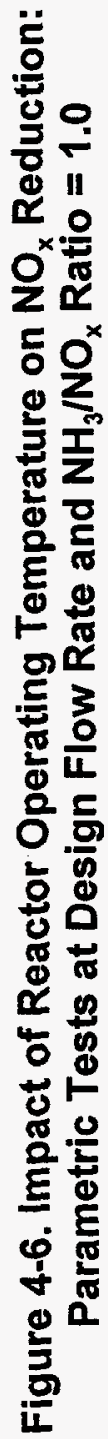


- Within the range of test temperatures, there was no clearly consistent impact of temperature on $\mathrm{NO}_{\mathrm{x}}$ reduction efficiency.

\subsubsection{Ammonia $\left(\mathrm{NH}_{3}\right)$}

The demonstration program included (1) investigations of possible gas-phase reactions of ammonia with other species in the flue gas and (2) the impact of SCR reactor operating conditions on ammonia slip (i.e., the amount of ammonia in the reactor outlet gas).

As part of the SCR reactor commissioning phase, the possibility of ammonia loss across empty SCR reactors, which might have occurred because of gas-phase reactions with oxygen, nitrogen oxides, or sulfur trioxide, was investigated. Simultaneous ammonia concentration measurements were made upstream and downstream of a single large reactor (B) and a single small reactor $(\mathrm{E})$ at four different operating conditions. Temperature and flue gas flow rate were varied in these tests; the $\mathrm{NH}_{3} \mathrm{NO}_{\mathrm{x}}$ ratio was 0.8 for all tests. The results of these tests are shown in Figures 4-7 and 4-8. Within the limits of the measurement technique used, no significant ammonia loss in the absence of catalyst was detected across either reactor.

Measurements were made during both preliminary and long-term parametric tests to determine the impact of SCR reactor operating conditions on ammonia slip across the SCR reactors. The results of these tests are summarized in Table 4-2. Bar graphs of ammonia slip at various target reactor operating conditions are provided in Figures 4-9 through 4-15. In some cases, deviations from the target reactor operating conditions led to higher ammonia slip concentrations. The following general conclusions can be drawn from these data:

- Ammonia slip generally increased at higher $\mathrm{NH}_{3} / \mathrm{NO}_{\mathrm{x}}$ ratio.

- Ammonia slip generally increased as the reactor residence time decreased (i.e., as the flue gas flow rate increased through the reactors) for a given operating temperature.

- Ammonia slip generally increased as the reactor operating temperature decreased.

\subsubsection{Sulfur Dioxide/Sulfur Trioxide $\left(\mathrm{SO}_{2} / \mathrm{SO}_{3}\right)$}

$\mathrm{SO}_{2}$ and $\mathrm{SO}_{3}$ concentrations in the $\mathrm{SCR}$ reactor inlet and outlet streams were measured periodically over the course of the demonstration program. The variation in SCR reactor inlet gas 


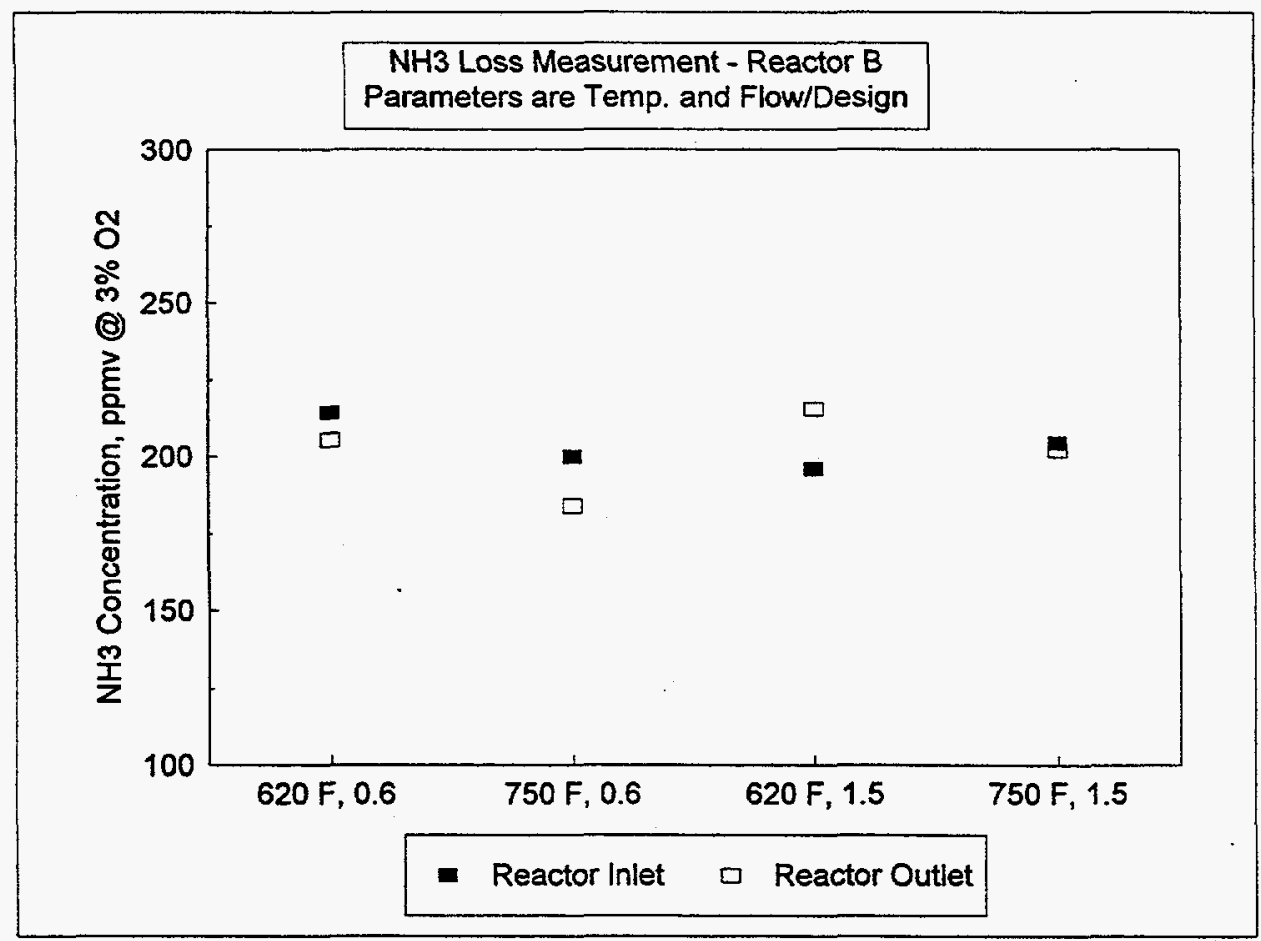

Figure 4-7. Ammonia Loss Across SCR Reactor Without Catalyst: Reactor B

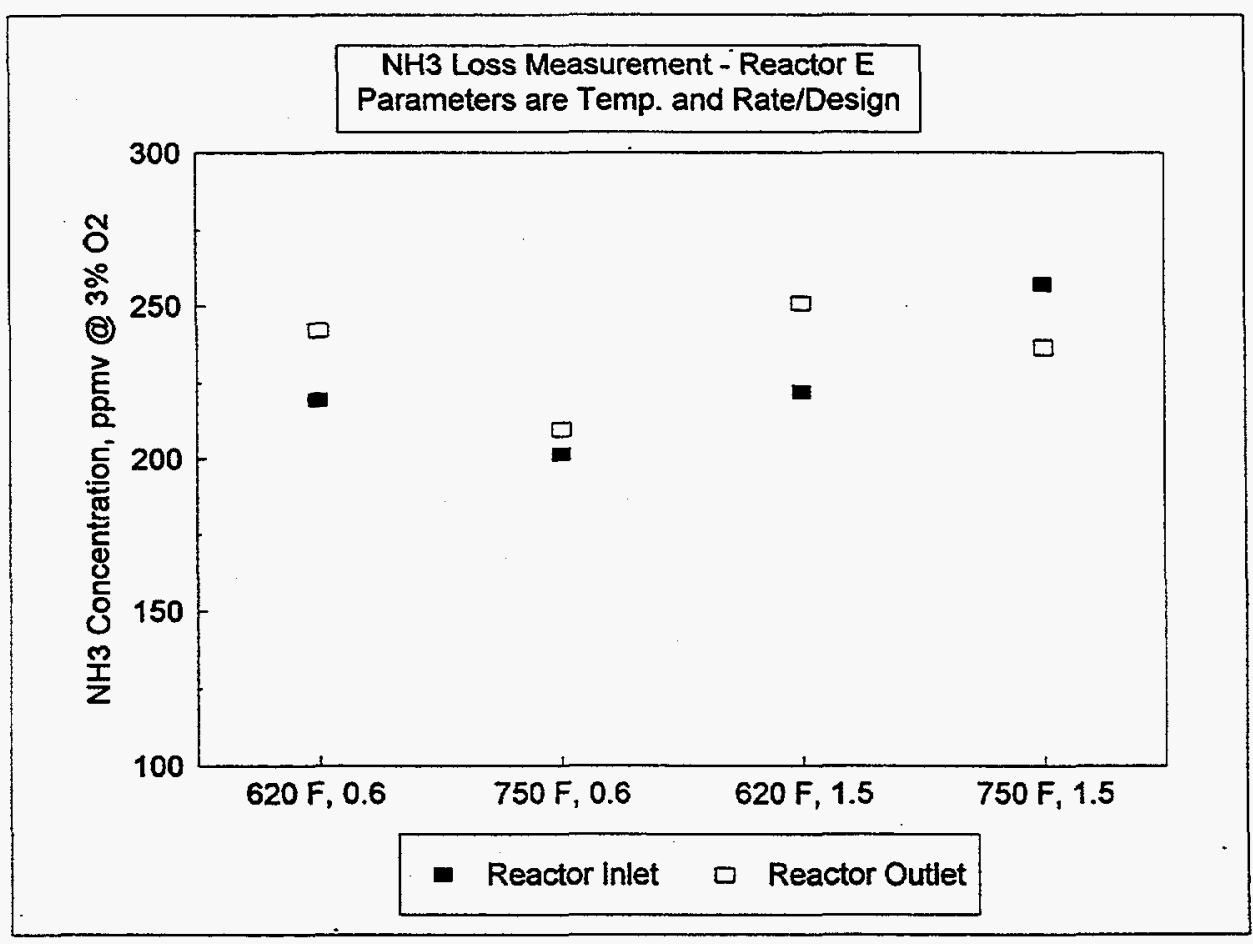

Figure 4-8. Ammonia Loss Across SCR Reactor Without Catalyst: Reactor E 
Table 4-2. Mean Ammonia Slip Concentrations During Parametric Tests

\begin{tabular}{|c|c|c|c|c|c|c|c|c|c|c|c|}
\hline \multicolumn{4}{|c|}{ Target Reactor Operating Conditions } & \multirow{2}{*}{\multicolumn{8}{|c|}{$\begin{array}{c}\text { Mean Ammonia Slip Concentration, dppmv @ 3\% } \mathrm{O}_{2} \\
\text { Reactor ID }\end{array}$}} \\
\hline \multirow{2}{*}{$\begin{array}{c}\text { Test Con- } \\
\text { dition }\end{array}$} & \multirow{2}{*}{$\underset{{ }^{\circ} \mathbf{F}}{\text { Temp., }}$} & \multirow{2}{*}{$\begin{array}{c}\text { Gas Rate/ } \\
\text { Design Rate }\end{array}$} & \multirow[b]{2}{*}{$\mathrm{NH}_{3} / \mathrm{NO}_{\mathbf{x}}$} & & & & & & & & \\
\hline & & & & $\mathbf{A}$ & B & C & D & $\mathbf{E}$ & $\mathbf{F}$ & $\mathbf{G}$ & $\mathbf{J}$ \\
\hline 2 & 620 & 0.6 & 0.8 & 1.6 & 1.1 & 1.4 & 5.4 & $<0.9$ & 10.9 & $<1.0$ & 1.1 \\
\hline 4 & 620 & 0.6 & 1.0 & $\underline{-a}$ & - & - & - & 2.4 & 8.1 & - & - \\
\hline 6 & 620 & 1.0 & 0.6 & 1.8 & $<0.8$ & 2.5 & 5.1 & $<0.8$ & 1.0 & $<0.9$ & 1.2 \\
\hline 7 & 620 & 1.0 & 0.8 & 3.3 & $<1.0$ & 6.6 & 12.2 & $<1.0$ & 2.3 & 1.8 & 2.0 \\
\hline 9 & 620 & 1.0 & 1.0 & 10.4 & 5.8 & 38.0 & 54.8 & 4.9 & 31.0 & 38.7 & 5.0 \\
\hline 12 & 620 & 1.5 & 0.8 & 9.8 & 2.4 & 7.0 & 36.1 & 1.4 & 4.6 & 1.3 & \\
\hline 14 & 620 & 1.5 & 1.0 & 14.5 & 17.3 & 38.2 & 72.2 & 33.5 & 38.1 & 20.6 & 15.7 \\
\hline 16 & 700 & 0.6 & 0.6 & 1.0 & - & 1.5 & - & - & - & - & - \\
\hline 19 & 700 & 0.6 & 1.0 & 2.1 & 1.8 & 16.5 & - & - & - & - & - \\
\hline 21 & 700 & 1.0 & 0.6 & 1.6 & $<1.1$ & 2.3 & 2.2 & $<1.1$ & 1.1 & 0.7 & $<0.8$ \\
\hline 22 & 700 & 1.0 & 0.8 & 3.3 & 1.6 & 4.1 & 4.6 & $<1.3$ & 13.8 & 1.7 & 1.1 \\
\hline 24 & 700 & 1.0 & 1.0 & 1.8 & 5.4 & 20.9 & 25.3 & 1.5 & 10.3 & 23.4 & 2.9 \\
\hline 26 & 700 & 1.5 & 0.6 & 1.6 & 1.0 & 4.8 & 5.0 & 0.8 & 3.2 & 2.5 & 1.5 \\
\hline 27 & 700 & 1.5 & 0.8 & 2.7 & 1.4 & 8.8 & 13.1 & 1.1 & 5.4 & 4.4 & 3.4 \\
\hline 29 & 700 & 1.5 & 1.0 & 4.9 & 4.9 & 25.3 & 38.9 & 6.7 & 28.7 & 21.5 & 12.3 \\
\hline 36 & 750 & 1.0 & 0.6 & 1.5 & 0.9 & 2.5 & 2.1 & $<0.9$ & 1.7 & 1.0 & 1.6 \\
\hline 37 & 750 & 1.0 & 0.8 & 1.9 & 0.9 & 4.9 & 4.5 & $<0.8$ & 1.9 & 2.1 & 2.8 \\
\hline 39 & 750 & 1.0 & 1.0 & 4.1 & 2.0 & 13.3 & 16.5 & $<0.8$ & 19.0 & 15.0 & 6.8 \\
\hline 42 & 750 & 1.5 & 0.8 & 2.9 & 0.9 & 4.4 & 15.4 & $<1.2$ & 3.7 & 2.3 & - \\
\hline
\end{tabular}

${ }^{a}$ Dash indicates that tests were not performed at these conditions. 
Parameters: Flow/Design, NH3/NOX

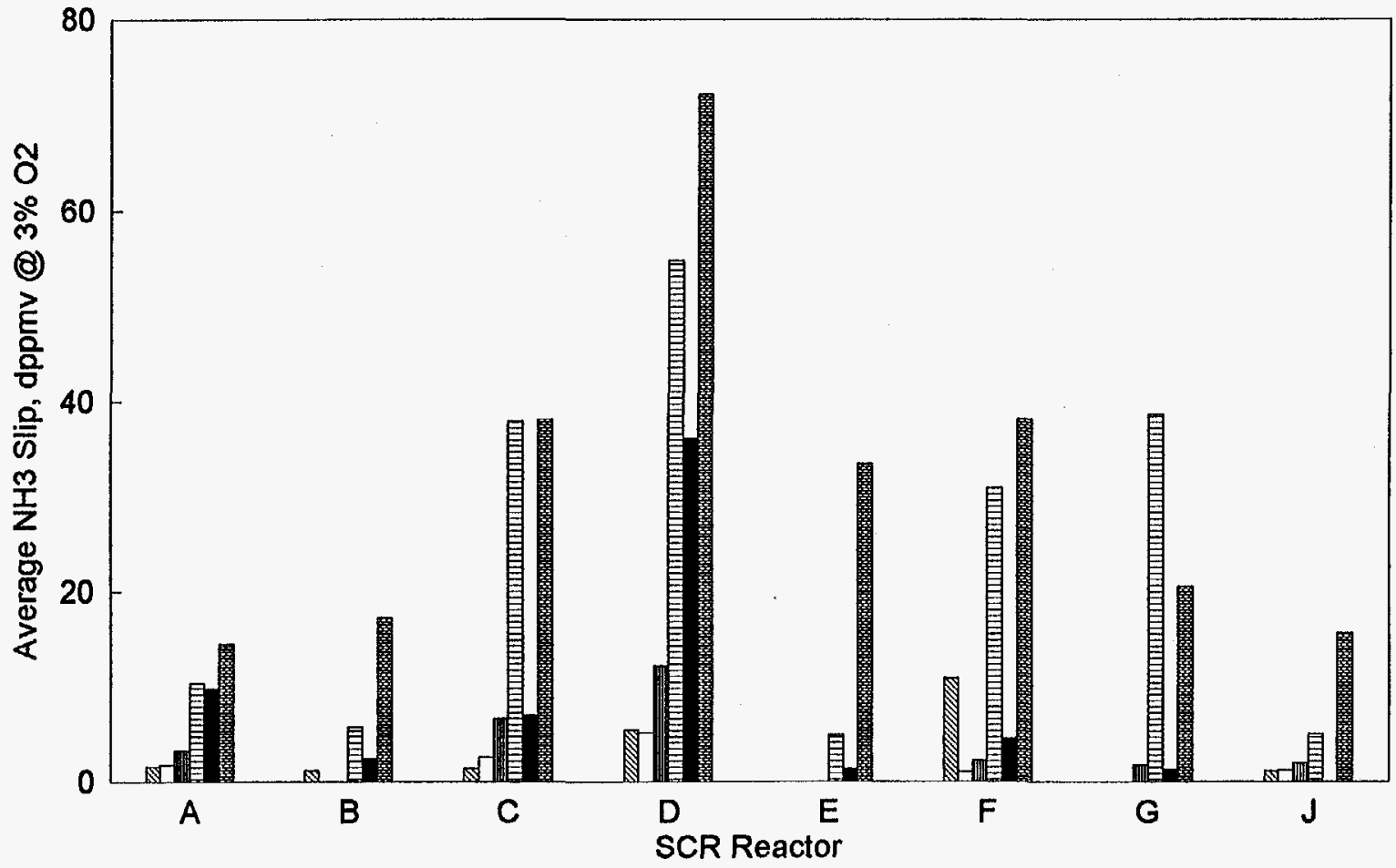

$0.6,0.8$

$1.0,0.6$

$1.0,0.8$

$1.0,1.0$

$1.5,0.8$

$1.5,1.0$

Figure 4-9. Effect of Gas Velocity and $\mathrm{NH}_{3} / \mathrm{NO}_{\mathrm{x}}$ Ratio on Ammonia Slip During $620^{\circ} \mathrm{F}$ Parametric Test Series 


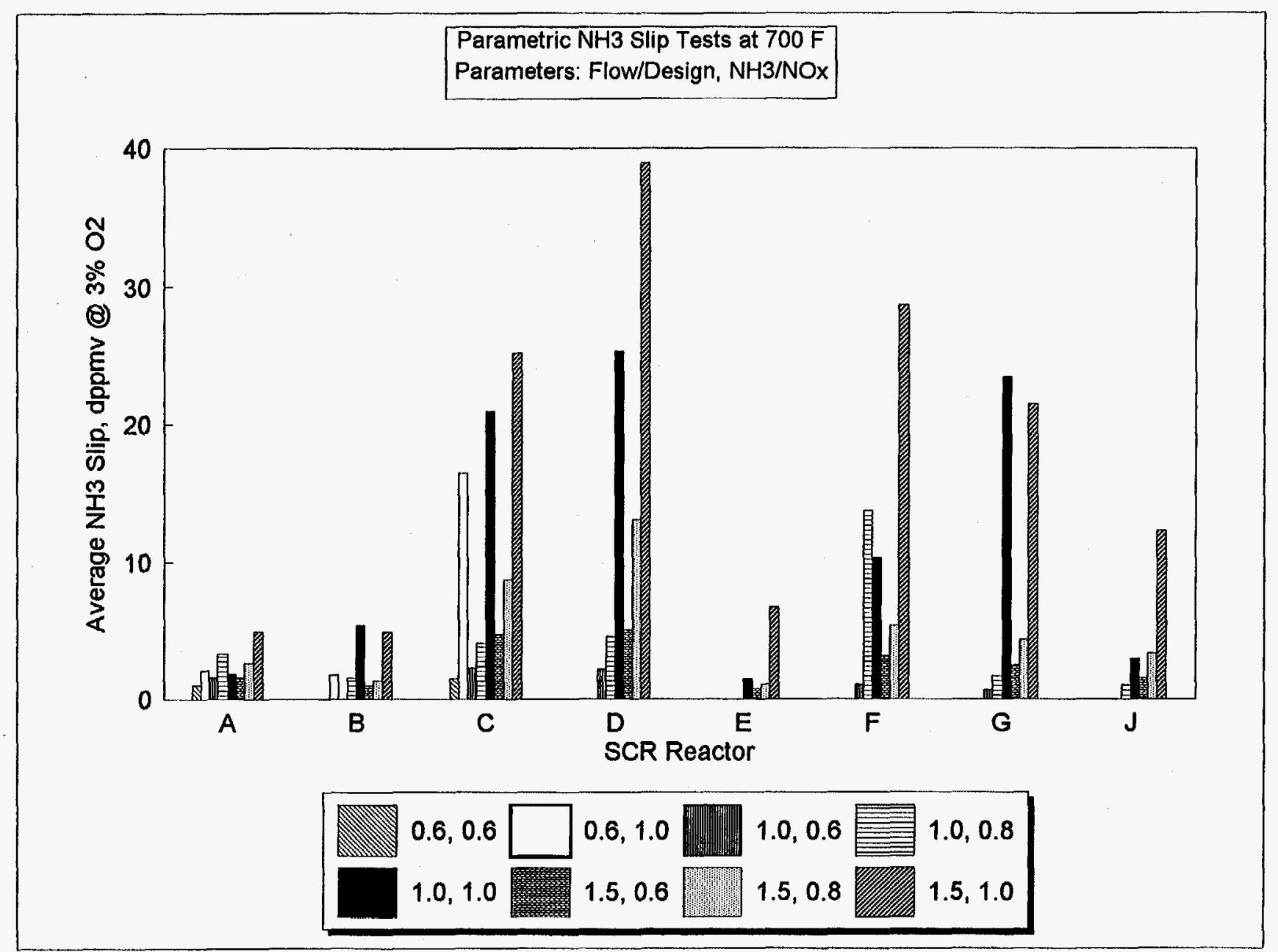

Figure 4-10. Effect of Gas Velocity and $\mathrm{NH}_{3} / \mathrm{NO}_{x}$ Ratio on Ammonia Slip During $700^{\circ} \mathrm{F}$ Parametric Test Series 


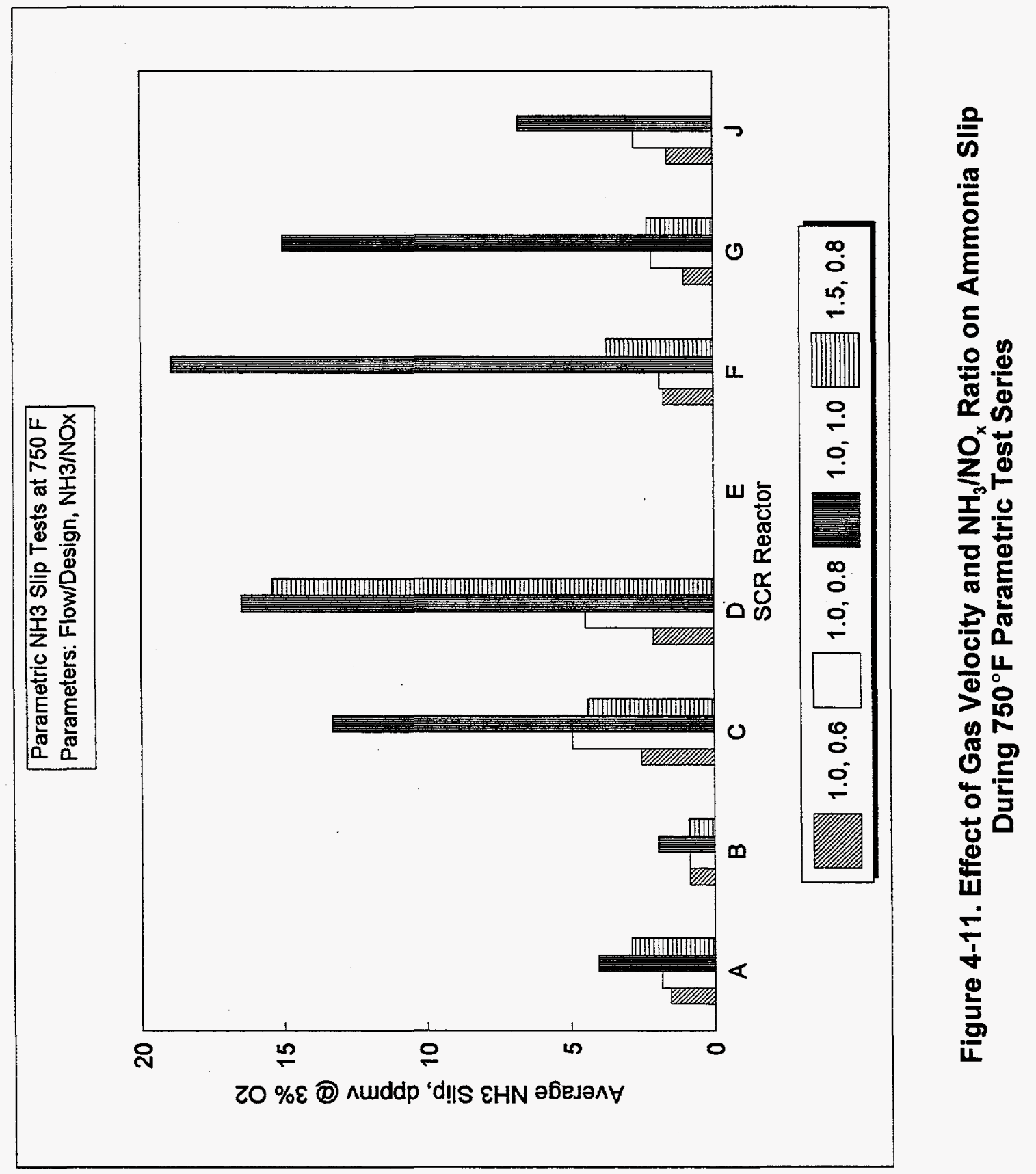




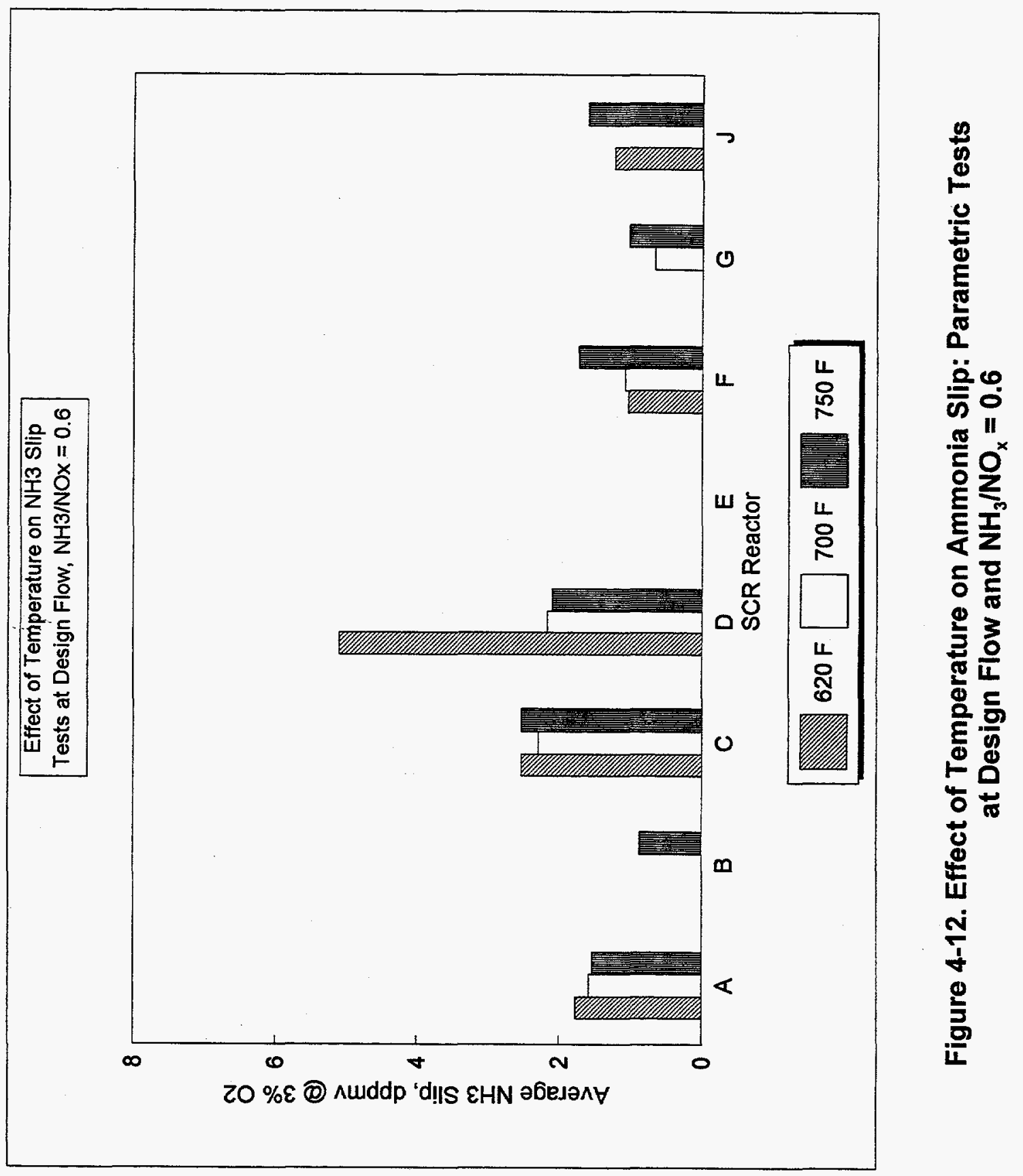




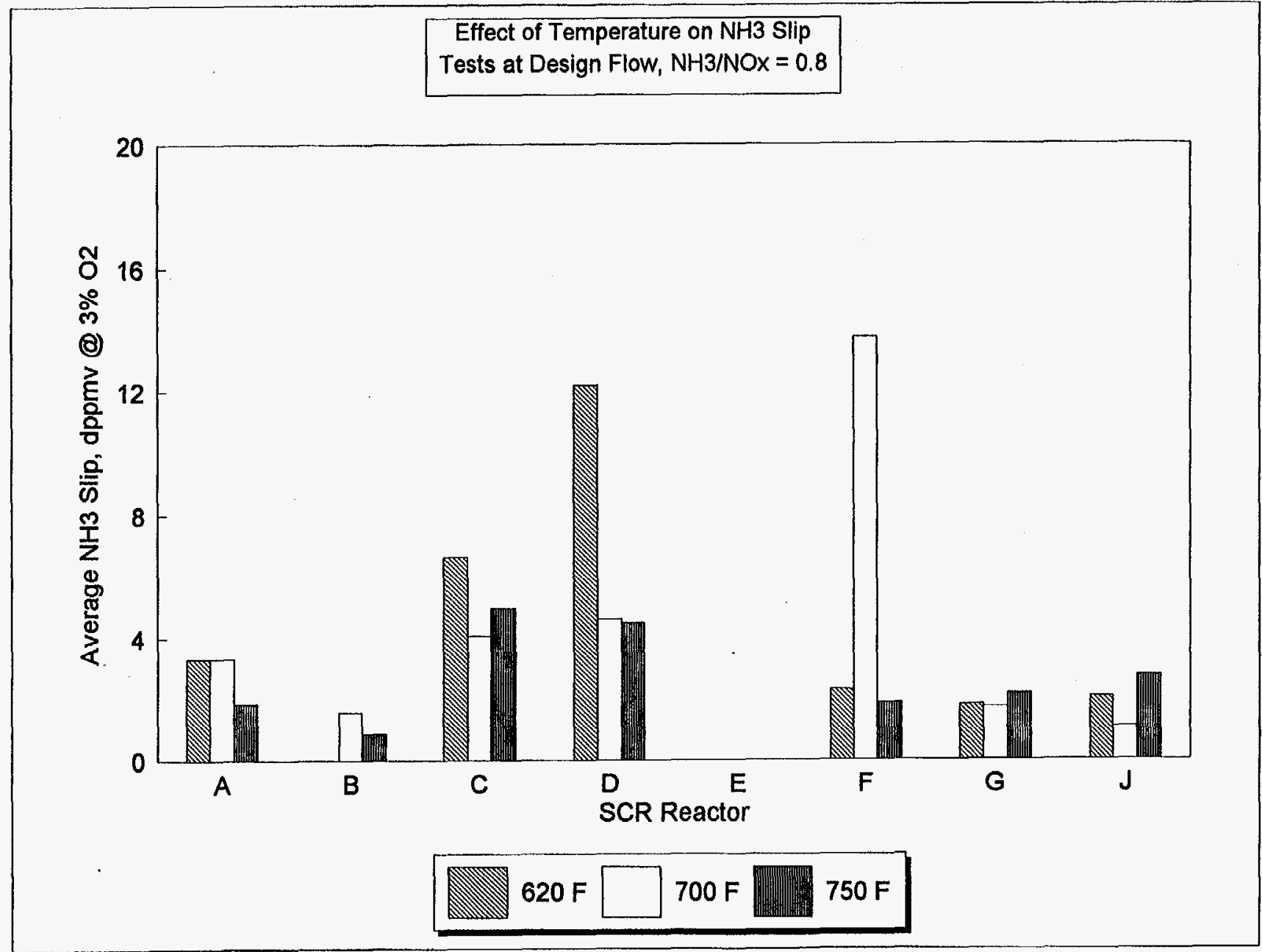

Figure 4-13. Effect of Temperature on Ammonia Slip: Parametric Tests at Design Flow and $\mathrm{NH}_{3} / \mathrm{NO}_{x}=0.8$ 


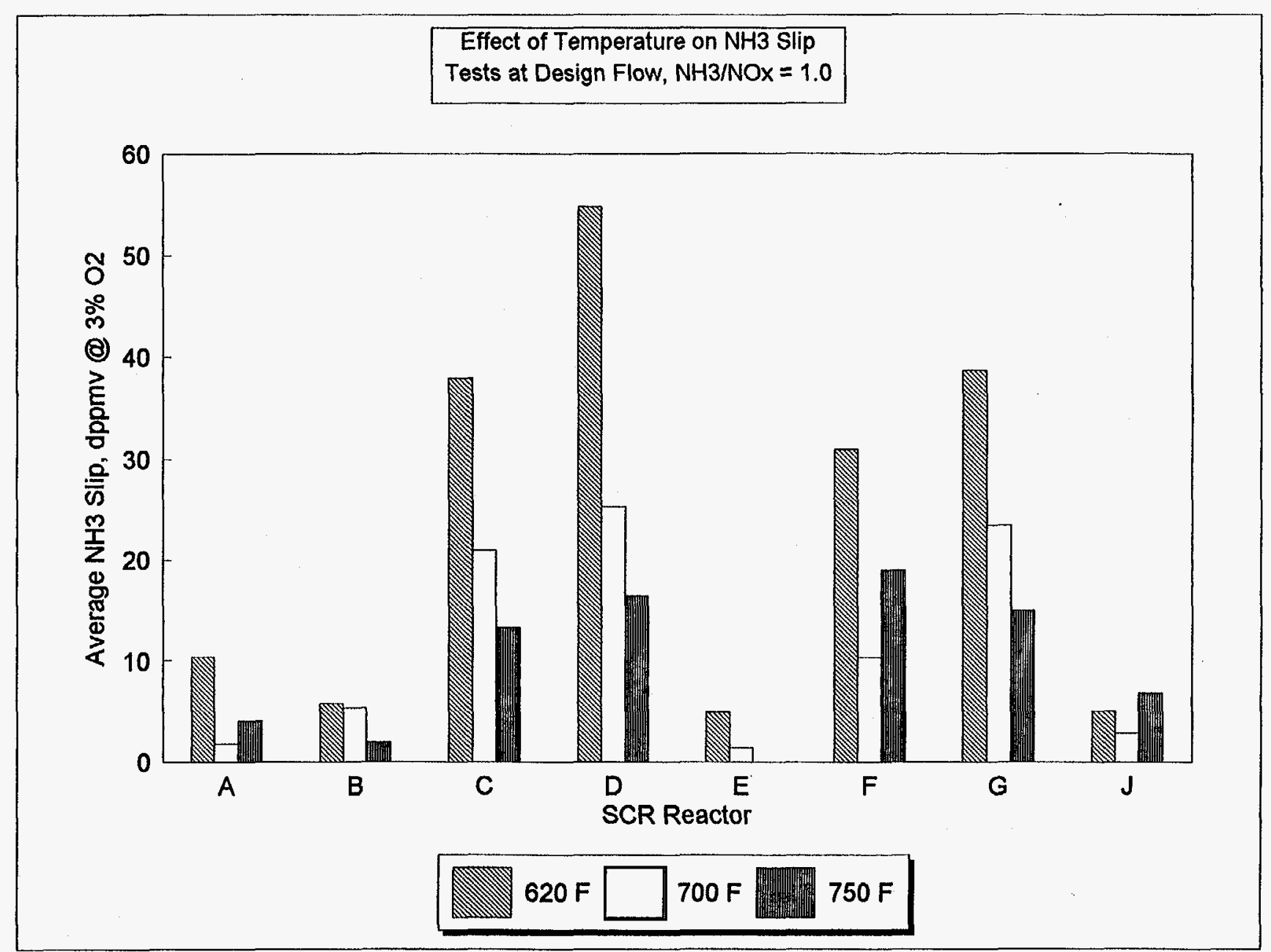

Figure 4-14. Effect of Temperature on Ammonia Slip: Parametric Tests at Design Flow and $\mathrm{NH}_{3} / \mathrm{NO}_{\mathrm{x}}=1.0$ 


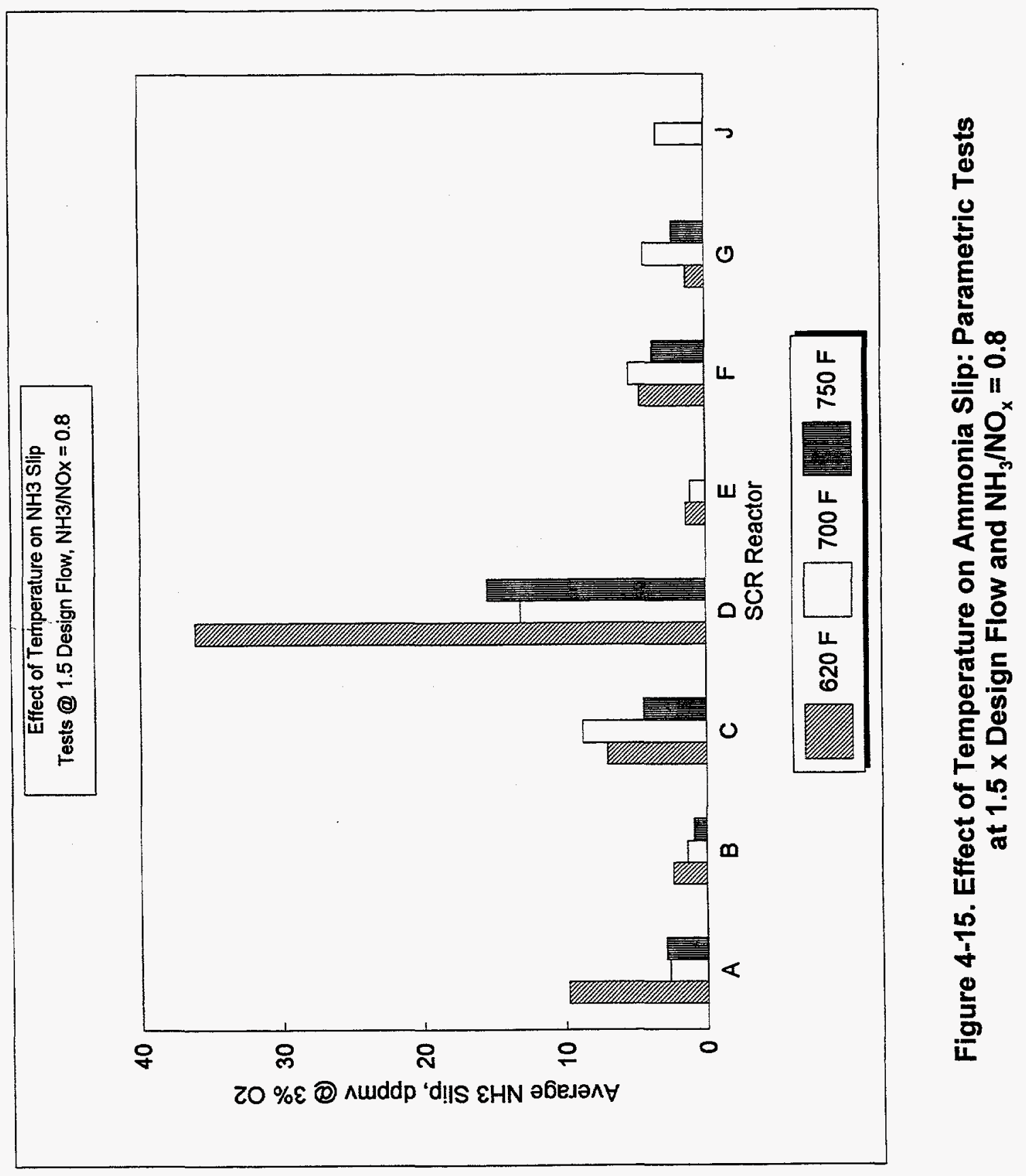


$\mathrm{SO}_{2}$ concentrations and coal sulfur content over time is shown in Figure 4-16. In general, the flue gas $\mathrm{SO}_{2}$ content increased with increasing coal sulfur content, as expected.

The conversion of $\mathrm{SO}_{2}$ to $\mathrm{SO}_{3}$ across the $\mathrm{SCR}$ reactors was investigated by measuring reactor inlet and outlet concentrations of both species at several sets of reactor operating conditions during preliminary parametric testing, and later during the long-term parametric tests. A summary of the mean conversions at each test condition is provided in Table 4-3; the detailed data can be found in Appendix A, Tables A-6, A-9, A-10, and A-11. As an example, the results of the $\mathrm{SO}_{2}$ conversion tests for SCR Reactor $\mathrm{A}$ are shown in Figure 4-17. In general, the fraction of the flue gas $\mathrm{SO}_{2}$ converted to $\mathrm{SO}_{3}$ across a given reactor increased with increasing temperature and increasing residence time (i.e., decreased flue gas flow rate). Figure 4-18 shows how the $\mathrm{SO}_{2}$ conversion across each reactor changed over time. In most cases, the fraction of $\mathrm{SO}_{2}$ converted to $\mathrm{SO}_{3}$ decreased slightly over time as the catalysts aged. Less than $0.5 \%$ of the $\mathrm{SO}_{2}$ was converted to $\mathrm{SO}_{3}$ in the majority of cases.

\subsubsection{Nitrous Oxide $\left(\mathrm{N}_{2} \mathrm{O}\right)$}

Nitrous oxide concentrations were measured at the inlet and outlet of the SCR reactors during three of the long-term parametric test series at baseline reactor operating conditions (i.e., $700^{\circ} \mathrm{F}$, design flow rates, and $\mathrm{NH}_{3} / \mathrm{NO}_{\mathrm{x}}$ ratio of 0.8 ). Care was taken to avoid the formation of $\mathrm{N}_{2} \mathrm{O}$ in the sample container following sample collection. Test results are summarized in Table 44 and Figure 4-19. Measured concentrations of $\mathrm{N}_{2} \mathrm{O}$ at the inlets and outlets of the reactors were all low, ranging from about $1 \mathrm{ppmv}$ to 3 ppmv. Within the precision of the measurements, there did not appear to be a significant change in $\mathrm{N}_{2} \mathrm{O}$ concentrations across the reactors.

\subsubsection{Hydrogen Chloride $(\mathrm{HCl})$}

Hydrogen chloride concentrations were measured at the reactor inlets and outlets during parametric tests conducted at the baseline reactor operating conditions (i.e., $700^{\circ} \mathrm{F}$, design flow rates, and $\mathrm{NH}_{3} / \mathrm{NO}_{\mathrm{x}}$ ratio of 0.8 ). The results are summarized in Table 4-5 and Figures 4-20 and 4-21. The apparent increase in measured $\mathrm{HCl}$ concentration across each of the SCR reactors during test sequence 4 (as shown in Figure 4-21) was very probably an artifact of the sampling method used to collect reactor inlet and outlet samples. The sampling protocol used at the reactor inlet did not include particulate catch. It is probable that some of the $\mathrm{HCl}$ reacted with ammonia upstream of the SCR reactors to form solid-phase ammonium chloride, which probably attached to the fly ash particles. Then, as the temperature was raised to the equilibrium temperature of the 


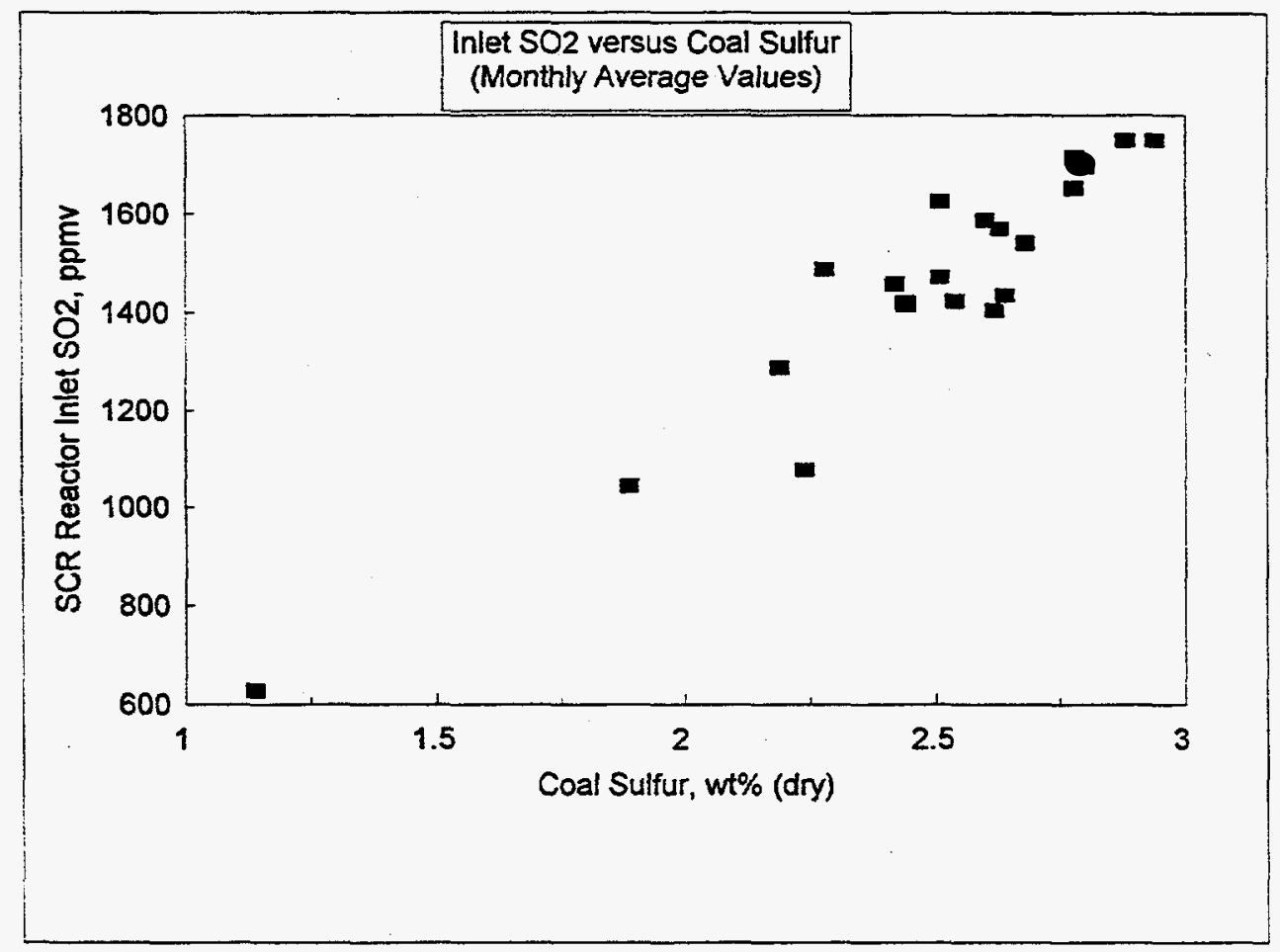

Figure 4-16. Variation of Reactor Inlet $\mathrm{SO}_{2}$ Concentration with Coal Sulfur Content 
Table 4-3. $\mathrm{SO}_{2}$ Conversion Test Results

\begin{tabular}{|c|c|c|c|c|c|c|c|c|c|c|c|}
\hline \multicolumn{4}{|c|}{ Target Reactor Operating Conditions } & \multicolumn{8}{|c|}{ Mean $\mathrm{SO}_{2}$ Conversion, $\%$ of Inlet $\mathrm{SO}_{2}$ Converted to $\mathrm{SO}_{3}$} \\
\hline $\begin{array}{c}\text { Test } \\
\text { Condition } \\
\end{array}$ & $\begin{array}{c}\text { Temp., } \\
{ }^{\circ} \mathbf{F}\end{array}$ & $\begin{array}{c}\text { Gas Rate/ } \\
\text { Design Rate }\end{array}$ & $\mathrm{NH}_{3} / \mathrm{NO}_{\mathbf{x}}$ & $\mathbf{A}$ & B & C & D & $\mathbf{E}$ & $\mathbf{F}$ & $\mathbf{G}$ & $\mathbf{J}$ \\
\hline 2 & 620 & 0.6 & 0.8 & 0.20 & 0.00 & $-{ }^{a}$ & - & - & - & $\ldots$ & - \\
\hline 7 & 620 & 1.0 & 0.8 & 0.07 & 0.00 & - & - & - & - & - & - \\
\hline 12 & 620 & 1.5 & 0.8 & 0.00 & 0.12 & - & - & - & - & - & - \\
\hline 17 & 700 & 0.6 & 0.8 & 1.15 & 0.44 & - & - & - & - & 一 & - \\
\hline 22 & 700 & 1.0 & 0.8 & 0.61 & 0.07 & 0.67 & 0.29 & 0.25 & 0.03 & 0.09 & 0.28 \\
\hline 27 & 700 & 1.5 & 0.8 & 0.83 & 0.21 & 0.00 & 0.00 & 0.34 & 0.00 & 0.11 & 0.29 \\
\hline 32 & 750 & 0.6 & 0.8 & 1.93 & 0.61 & 2.64 & - & - & - & - & - \\
\hline 37 & 750 & 1.0 & 0.8 & 1.82 & 0.45 & 1.53 & 0.80 & 0.59 & 0.06 & 0.74 & 0.60 \\
\hline 42 & 750 & 1.5 & 0.8 & 1.22 & 0.25 & 1.99 & - & - & - & - & - \\
\hline
\end{tabular}

$\stackrel{+}{N}$

${ }^{a}$ Dash indicates that testing was not performed at these conditions. 


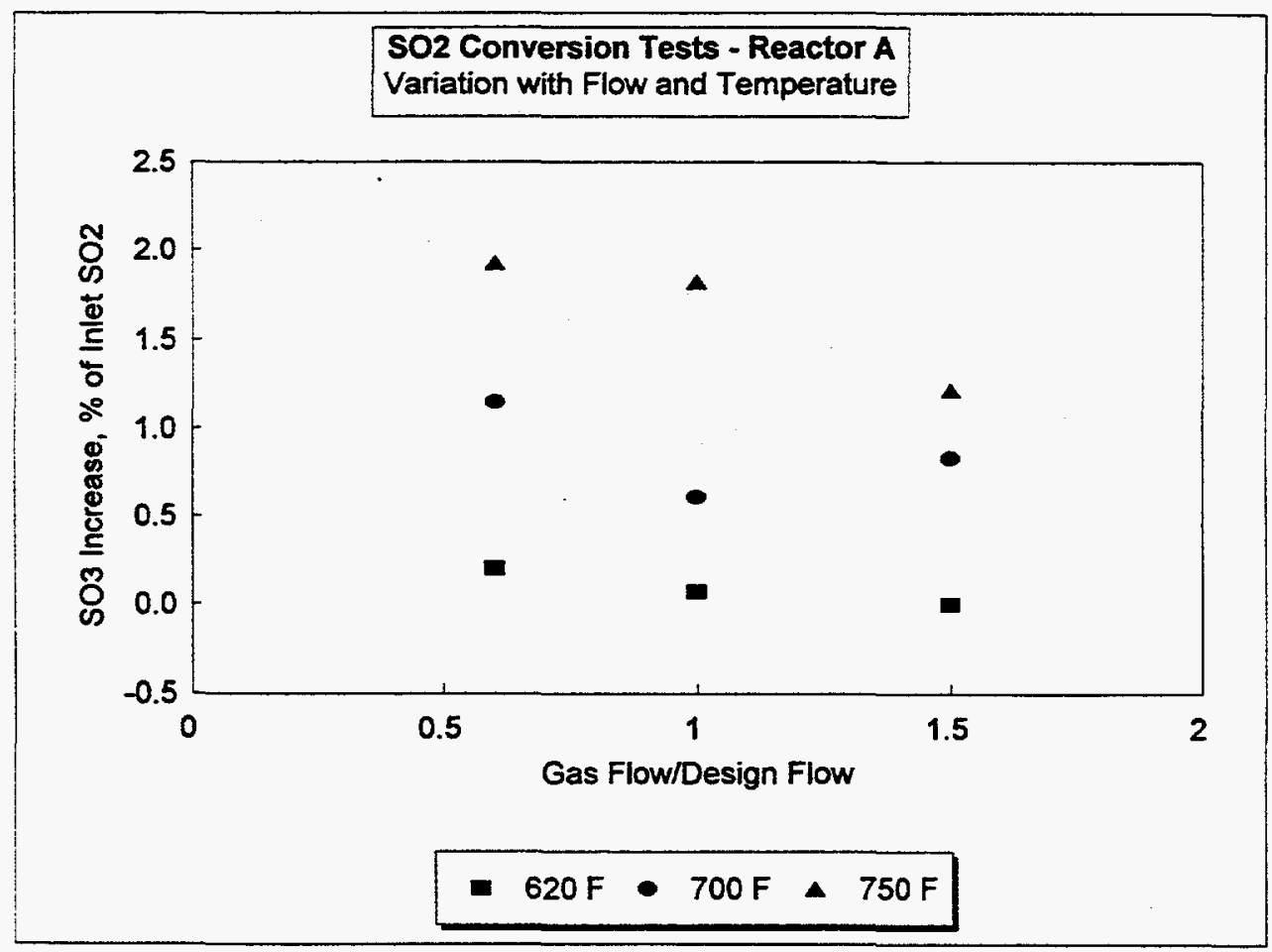

Figure 4-17. Example of Variation in $\mathrm{SO}_{2}$ Conversion with Flue Gas Flow and Reactor Temperature-Reactor $A$ 


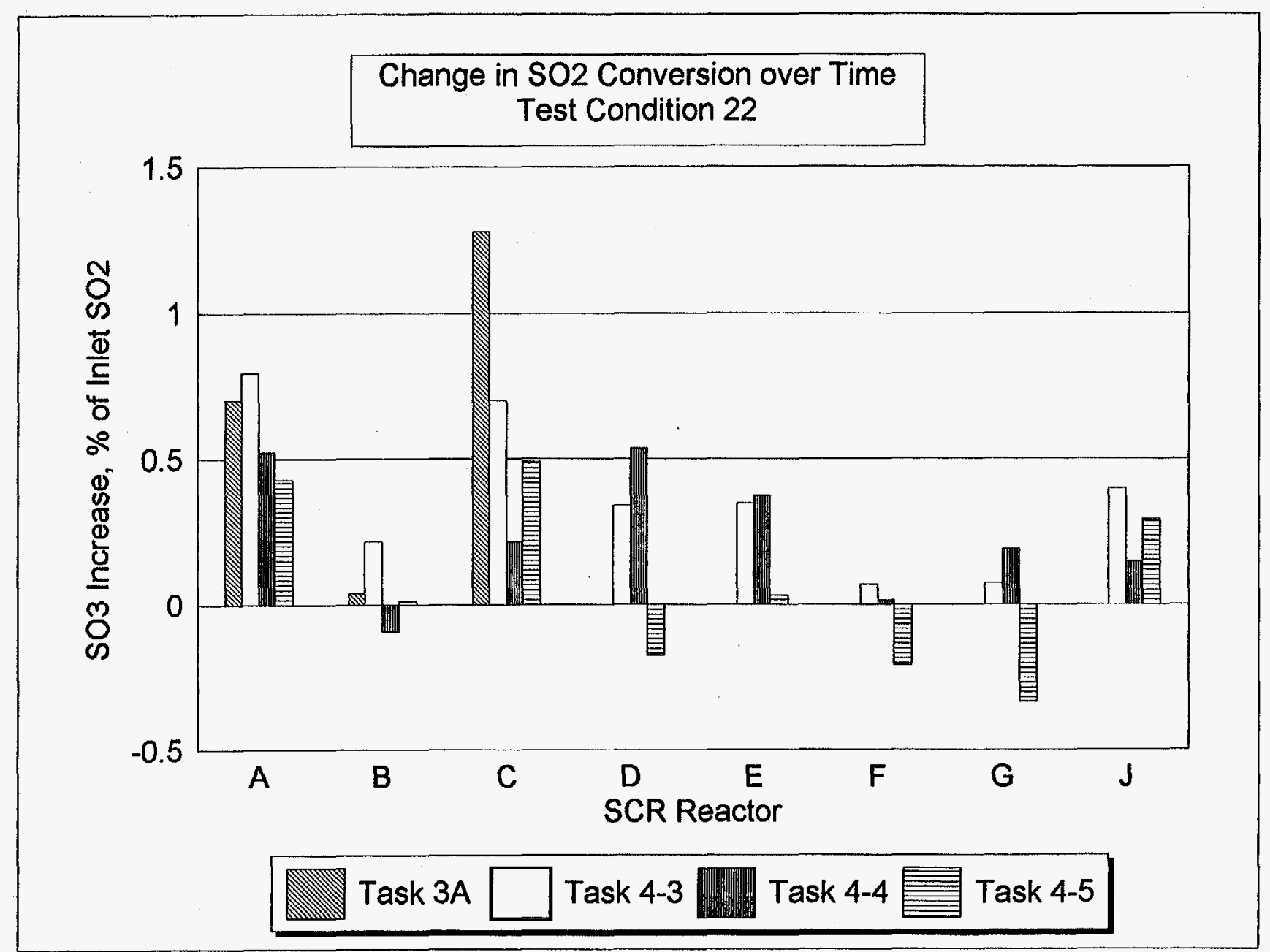

Figure 4-18. Change in $\mathrm{SO}_{2}$ Conversion Across SCR Reactors with Exposure Time 
Table 4-4. Mean Nitrous Oxide Concentration Summary

(dry ppmv at $3 \% \mathrm{O}_{2}$ )

\begin{tabular}{|c|c|c|c|c|c|c||}
\hline \multirow{2}{*}{$\begin{array}{c}\text { SCR } \\
\text { Reactor }\end{array}$} & \multicolumn{2}{|c|}{ Test Sequence 2 } & \multicolumn{2}{c|}{ Test Sequence 4 } & \multicolumn{2}{c|}{ Test Sequence 5 } \\
\cline { 2 - 7 } & Inlet & Outlet & Inlet & Outlet & Inlet & Outlet \\
\hline \hline A & 2.4 & 1.2 & 1.2 & 1.3 & 2.0 & 1.6 \\
\hline B & 2.4 & 1.0 & 1.2 & 1.3 & 2.0 & 1.6 \\
\hline C & 2.4 & 1.7 & 1.2 & 2.0 & 2.0 & 2.5 \\
\hline D & 1.8 & 1.8 & 1.2 & 2.0 & 2.0 & 2.1 \\
\hline E & 1.8 & 1.8 & 1.2 & 1.8 & 2.0 & 1.8 \\
\hline F & 2.4 & 1.6 & 1.2 & 2.0 & 2.0 & 2.2 \\
\hline G & 2.4 & 1.6 & 1.2 & 2.3 & 2.0 & 1.6 \\
\hline J & $-{ }^{\mathrm{a}}$ & - & 1.2 & 2.5 & 2.0 & 2.9 \\
\hline
\end{tabular}

a Dash indicates that tests were not performed at these points. 


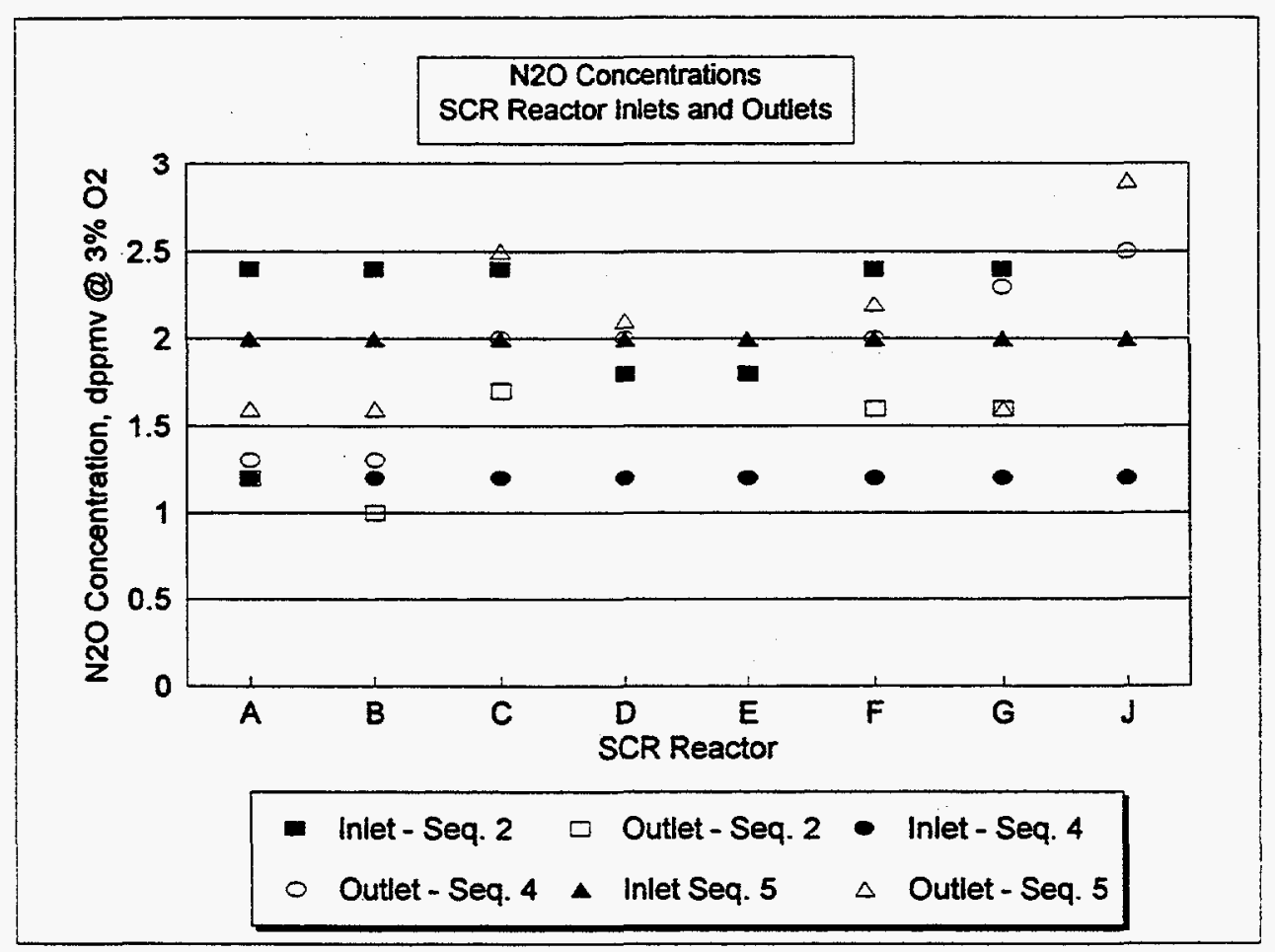

Figure 4-19. Reactor Inlet and Outlet Nitrous Oxide Concentrations 
Table 4-5. $\mathrm{HCl}$ Concentration Summary

\begin{tabular}{|c|c|c|c|c|}
\hline \multirow{2}{*}{$\begin{array}{c}\text { Test } \\
\text { Sequence }\end{array}$} & \multirow[b]{2}{*}{ SCR Reactor } & \multirow[b]{2}{*}{ Date } & \multicolumn{2}{|c|}{ HCl Conc., dppmv@3\% $\mathrm{O}_{2}$} \\
\hline & & & Inlet & Outlet \\
\hline 1 & A & 06Aug93 & $\ldots$ & 178 \\
\hline 1 & $\mathrm{~B}$ & 16Ju193 & - & 152 \\
\hline 1 & $\mathrm{C}$ & 14Jul93 & - & 137 \\
\hline 1 & $\mathrm{C}$ & $15 \mathrm{Jul} 93$ & - & 143 \\
\hline 1 & $\mathrm{C}$ & 19Jul93 & - & 125 \\
\hline 1 & $\mathrm{D}$ & 27 Oct93 & - & 135 \\
\hline 1 & $E$ & 27 Oct93 & - & 211 \\
\hline 1 & $\mathrm{~F}$ & $270 c t 93$ & - & 202 \\
\hline 2 & A & $28 \operatorname{Jan} 94$ & - & 241 \\
\hline 2 & $\mathrm{~B}$ & $01 \mathrm{Feb} 94$ & - & 158 \\
\hline 2 & $\mathrm{C}$ & 28Jan94 & - & 211 \\
\hline 2 & $\mathrm{D}$ & $02 \mathrm{Feb} 94$ & - & 163 \\
\hline 2 & $\mathrm{E}$ & 17Mar94 & 一 & 196 \\
\hline 2 & $\mathrm{~F}$ & 16Mar94 & - & 140 \\
\hline 2 & $G$ & 23Mar94 & - & 157 \\
\hline 3 & A & 20 Sep 94 & - & 233 \\
\hline 3 & B & 19Sep94 & - & 238 \\
\hline 3 & $\mathrm{C}$ & 20Sep94 & - & 233 \\
\hline 3 & $\mathrm{D}$ & 23Sep94 & - & 232 \\
\hline 3 & $\mathrm{E}$ & 23Sep94 & - & 226 \\
\hline 3 & $\mathrm{~F}$ & 20Sep94 & - & 241 \\
\hline 3 & $\mathrm{G}$ & 21Sep94 & - & 225 \\
\hline 3 & $\mathrm{~J}$ & 21Sep94 & - & 234 \\
\hline 4 & $\mathrm{~A}$ & 01 Dec94 & 139 & 219 \\
\hline 4 & B & 30 Nov94 & 161 & 222 \\
\hline 4 & $\mathrm{C}$ & 28 Nov 94 & 195 & 260 \\
\hline 4 & D & 05Dec94 & 164 & 223 \\
\hline 4 & $\mathrm{E}$ & 06Dec94 & 176 & 233 \\
\hline 4 & $F$ & 07Dec94 & 174 & 250 \\
\hline 4 & $\mathrm{G}$ & 08Dec94 & 189 & 256 \\
\hline 4 & $\mathrm{~J}$ & 09Dec94 & 179 & 244 \\
\hline 5 & $\mathrm{~A}$ & 03Jun95 & 132 & 86 \\
\hline
\end{tabular}

${ }^{a}$ Dash indicates that measurements were not made at these locations. 


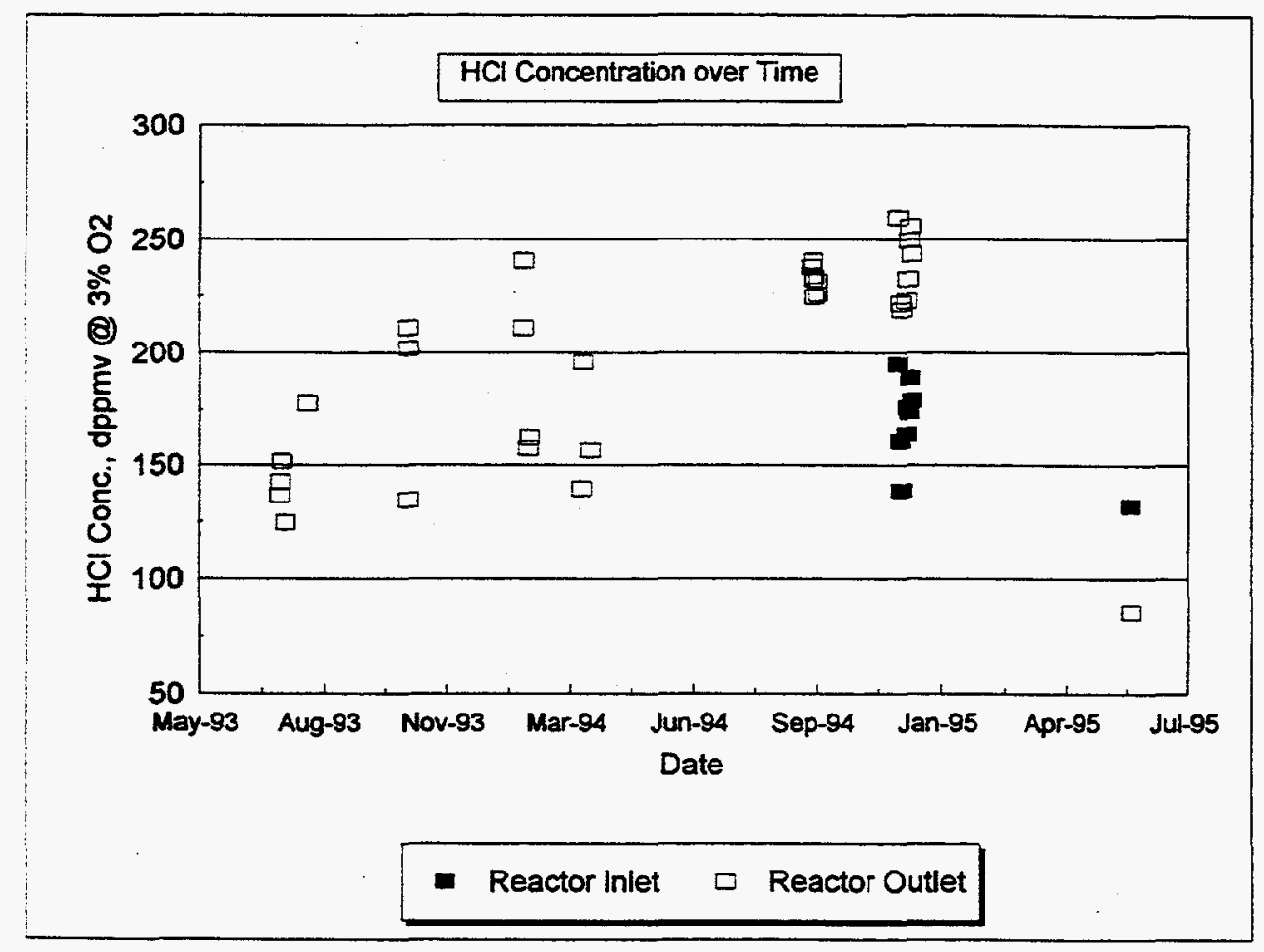

Figure 4-20. Variation in Reactor Outlet $\mathrm{HCl}$ Concentrations with Time

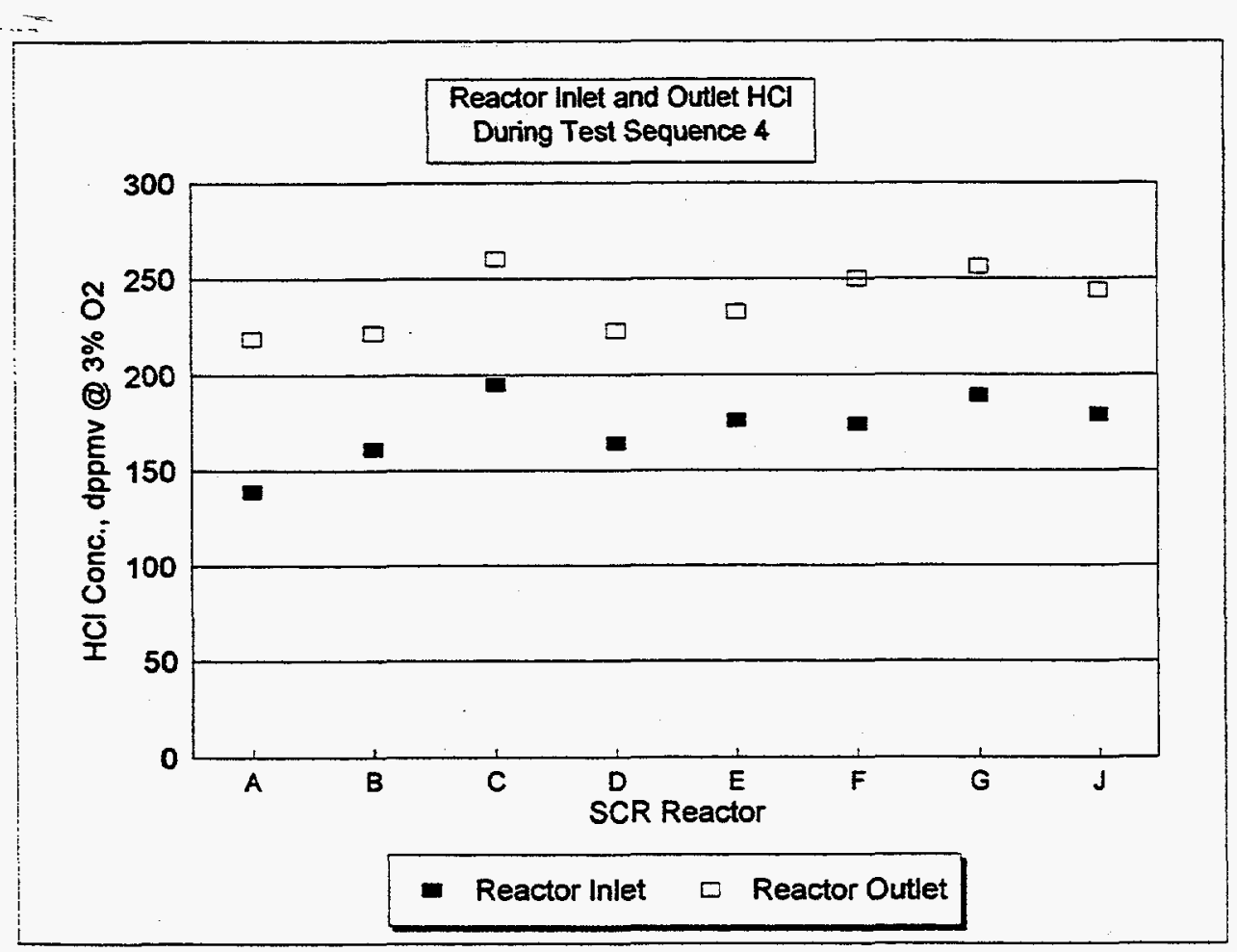

Figure 4-21. Reactor Inlet and Outlet Hydrogen Chloride Concentrations 
SCR reactors, the ammonium chloride probably evolved back into its original components (ammonia and $\mathrm{HCl}$ ), thus resulting in an apparent increase in the $\mathrm{HCl}$ concentration.

\subsubsection{Particulate Matter}

Particulate matter (PM) sampling and analyses were conducted (1) to demonstrate that the concentration (i.e., loading) and particle size of the PM in the flue gas to each SCR reactor were similar to those characteristics in the flue gas flowing to the Unit 5 hot-side ESP; (2) to determine the particulate loading downstream of the three large SCR reactors and around the air preheaters downstream of these reactors; and (3) to characterize the composition of the fly ash at these locations, including ash minerals, trace metals, ammonia, and TCLP analyses.

\section{PM Loading: Low-Dust Flue Gas}

The mean particulate matter loading in the low-dust flue gas leaving the hot-side ESP was 0.0043 grains per dry standard cubic foot (gr/dscf), at high boiler load conditions ( $84 \mathrm{MWe}$ ); the corresponding loading measured at the inlet of the low-particulate SCR reactor (Reactor J) was $0.0022 \mathrm{gr} / \mathrm{dscf}$. The difference between these measurements was probably due to differences in sampling methods used at the two locations. The ESP outlet flue gas measurements were conducted using a detailed traverse of the entire outlet duct cross section, while the Reactor $J$ take-off duct samples (reactor inlet samples) represented only a fraction of the total duct crosssectional area. At low boiler load ( $43 \mathrm{MWe}$ ), the mean particulate loading in the ESP outlet flue gas was $0.0007 \mathrm{gr} / \mathrm{dscf}$; no measurements were made of the Reactor J inlet duct particulate loading at this operating condition because of the extremely low levels expected.

\section{Loading: High-Dust Flue Gas}

The first set of particulate matter loading measurements in the high dust flue gas showed that modifications to the design of the flue gas inlet (to the SCR reactors) transition piece were needed to improve the isokinetic flow between the transition piece and the ducting to the five small high-dust reactors (Reactors D, E, F, G, and $\mathrm{H}$ ). The results of tests conducted after these modifications were completed are summarized in Table 4-6 and Figure 4-22. Because of difficulties in collecting representative samples at the inlet to each of the five small high-dust reactors, the measurements were made downstream of the last catalyst layer in each reactor. Tests were conducted with the Unit 5 boiler operating at two load conditions: high (84 MW) and low (43 MW). The average PM concentration at high boiler load was $3.9 \mathrm{gr} / \mathrm{dscf} @ 3 \% \mathrm{O}_{2}$. At low boiler load conditions, the average PM concentration for all eight high-dust reactors was 3.5 gr/dscf @ $3 \% \mathrm{O}_{2}$. By comparison, the average PM loadings at the ESP inlet at high and low 
Table 4-6. Average SCR Reactor Outlet PM Loadings ${ }^{a}$

\begin{tabular}{|c|c|c|c|c|c|c||}
\hline \multirow{2}{*}{$\begin{array}{c}\text { SCR } \\
\text { Reactor }\end{array}$} & Low Load & \multicolumn{5}{|c|}{ High Load } \\
\cline { 2 - 7 } & Task1 & Task1 & $\begin{array}{c}\text { Task 4 } \\
\text { Sequence 1 }\end{array}$ & $\begin{array}{c}\text { Task 4 } \\
\text { Sequence 2 }\end{array}$ & $\begin{array}{c}\text { Task 4 } \\
\text { Sequence 4 }\end{array}$ & Mean \\
\hline \hline A & 3.60 & 3.91 & $-^{-}$ & 3.49 & 3.87 & 3.75 \\
\hline B & 3.41 & 4.13 & 4.99 & 3.78 & 3.27 & 4.04 \\
\hline C & 3.51 & 3.84 & 4.77 & 3.27 & 3.42 & 3.82 \\
\hline D & 3.46 & 3.13 & 2.89 & 3.72 & 4.24 & 3.49 \\
\hline E & 3.88 & 4.20 & 3.39 & 5.25 & 4.25 & 4.27 \\
\hline F & 3.74 & 4.38 & 4.01 & $7.87^{d}$ & 4.34 & 4.24 \\
\hline G & 3.29 & 3.88 & - & - & 3.31 & 3.59 \\
\hline H & 3.29 & 3.75 & - & - & - & 3.75 \\
\hline
\end{tabular}

${ }^{\mathrm{a}}$ Units = grains/dry standard cubic feet.

${ }^{\mathrm{b}}$ No tests were conducted during Test 4, Sequence 3.

${ }^{c}$ Dash indicates that no loading tests were performed at these conditions.

${ }^{\mathrm{d}}$ Not included in calculation of overall mean. 


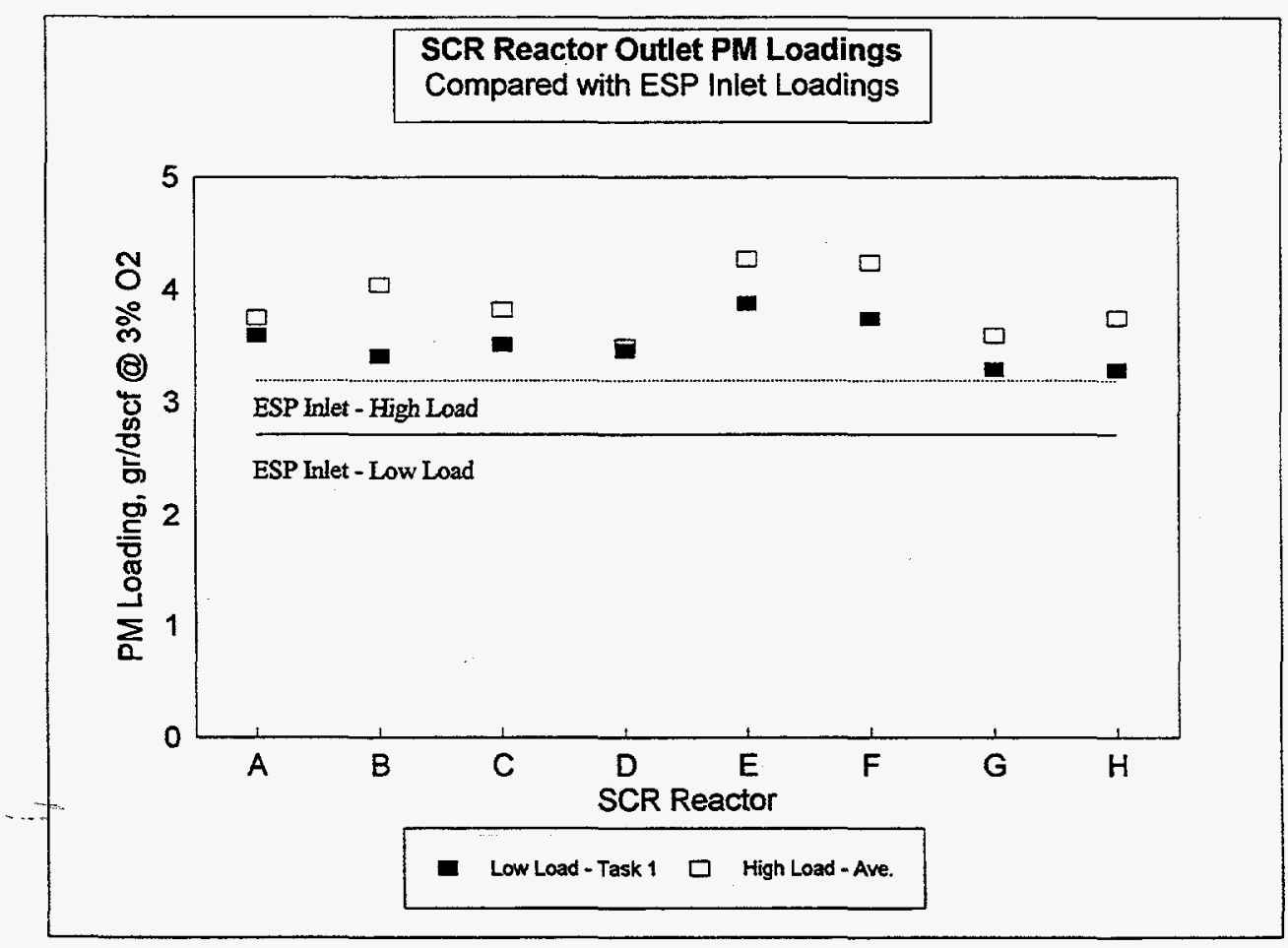

Figure 4-22. SCR Reactor Outlet PM Loadings Compared with ESP Inlet Loadings 
boiler load conditions were 3.2 and $2.7 \mathrm{gr} / \mathrm{dscf}$, respectively. Subsequent measurements of particulate loadings in the economizer bypass duct at low load conditions showed that the particulate loading measured at the ESP inlet may have been low. The average mass loading in the economizer bypass duct, $3.60 \mathrm{gr} / \mathrm{dscf}$, was comparable to that found in the reactor outlets at similar boiler load conditions.

The average particulate loading at various locations downstream of the three large highdust reactors are shown in Figure 4-23. As expected, PM loadings at the SCR reactors outlets and air preheater inlets were comparable, while lower loadings were measured downstream of the preheaters, indicative of some particulate deposition in the air preheaters.

\section{Particle Size Distribution}

Figures 4-24 and 4-25 present the differential particle size distributions for the fly ash downstream of the third catalyst level for the high-dust reactors at high and low boiler loads, respectively. For comparison purposes, Figures 4-26 and 4-27 show the average distributions for all eight high-dust reactors compared with the size distribution of the particulate collected at the main ESP inlet at the two boiler loads. The solid lines represent a range of one standard deviation about the mean of particle size distribution in the eight reactors. For both high- and low-load conditions, the particle size distribution at the main inlet to the high-dust reactors agreed very well with the average size distribution measured at the outlet of the eight high-dust SCR reactors.

\section{Fly Ash Composition}

Table 4-7 summarizes the results of the ash minerals analyses that were conducted on fly ash samples collected at various locations during the SCR demonstration project. The data show that the compositions of the fly ash entering and leaving the three large high-dust reactors and the air preheaters were very similar to the composition of the coal ash. The trace metals concentrations in the fly ash samples are shown in Table 4-8. Considerably more variability can be seen in these measurements compared with the major ash minerals. This is consistent with the inherent variability of trace element levels in coal.

\section{Ammonia on Particulates}

Southern Research Institute conducted a laboratory study to evaluate the effects of SCR ammonia levels on ammonia volatilization, ammonia extraction, and metals extractability from fly ash (9). Samples of pre-SCR reactor (ammonia-free) and post-SCR reactor (ammoniaexposed) fly ash were collected from SCR Reactors B and C. The associated EMP monitoring 


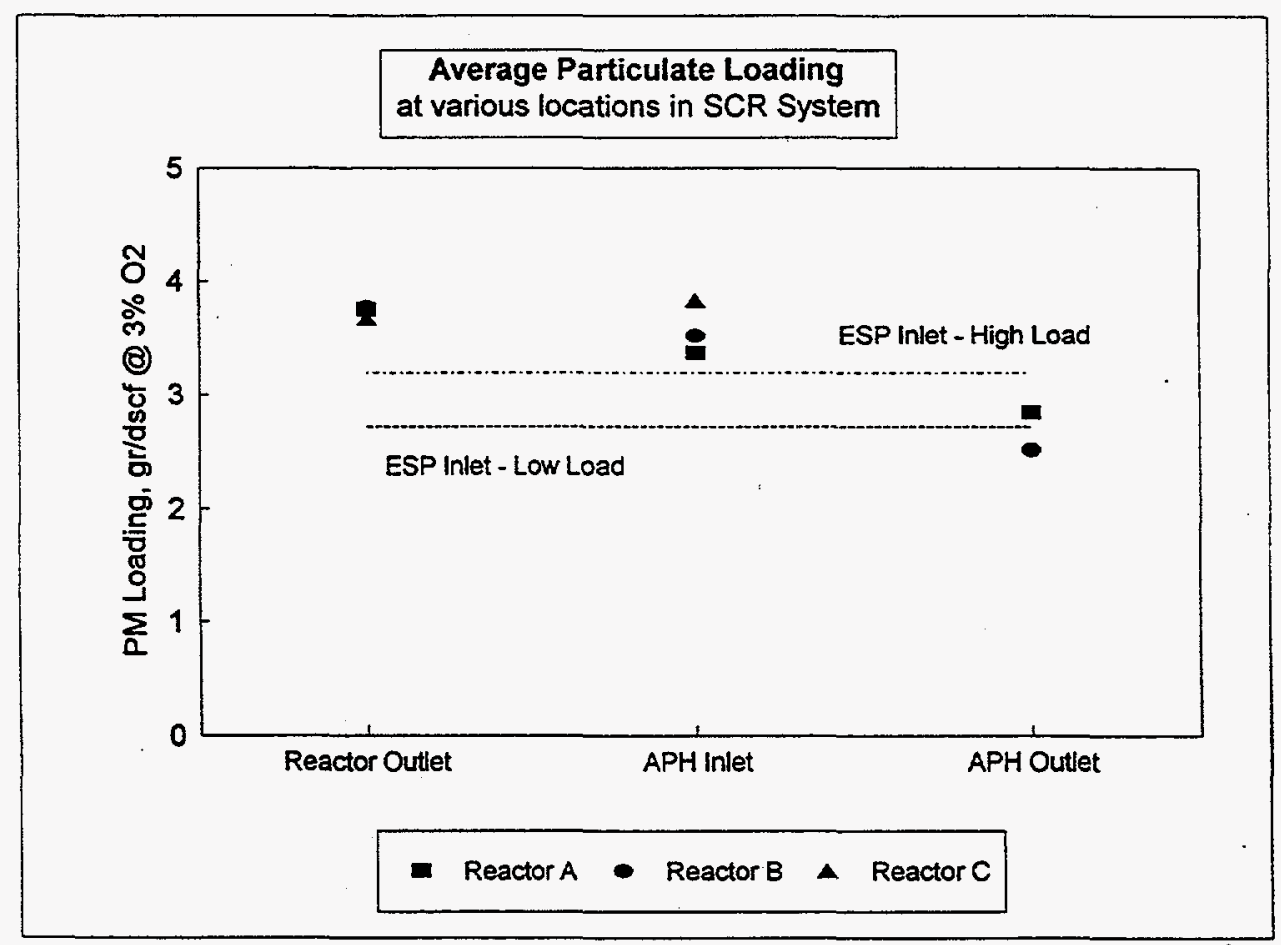

Figure 4-23. Average Particulate Loading at Various Locations in the SCR System 


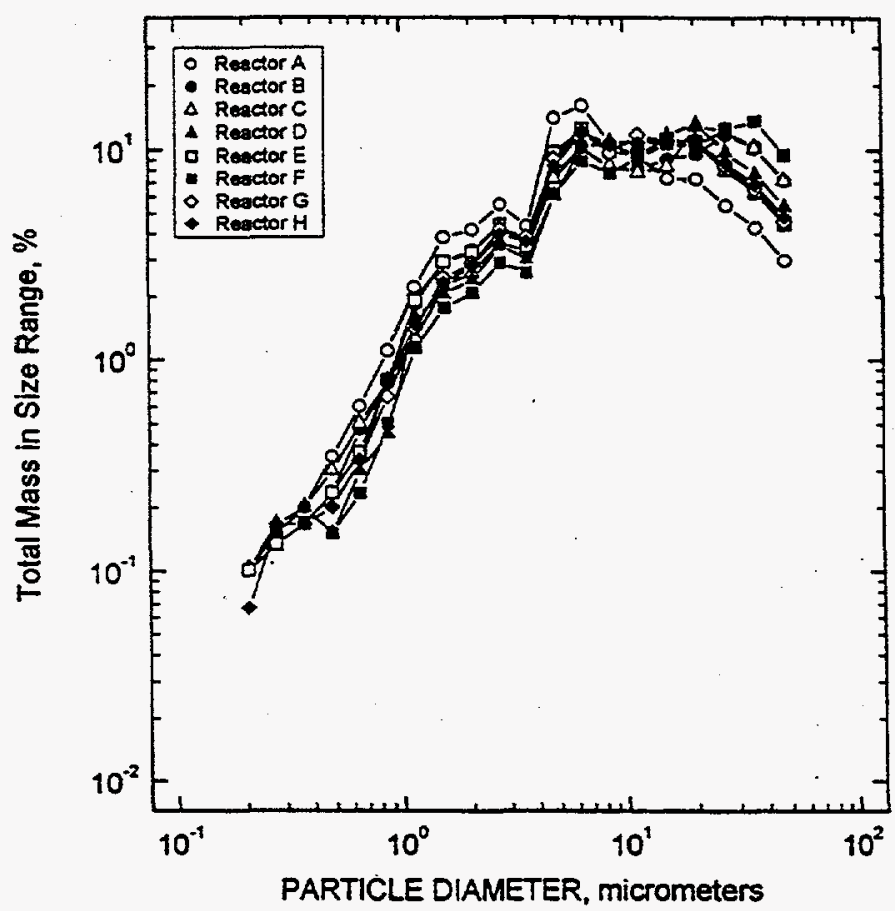

Figure 4-24. Differential Particle Size Distribution for Fly Ash Collected Downstream of the Third Reactor Level (High-Dust Reactors)

During High-Load Tests

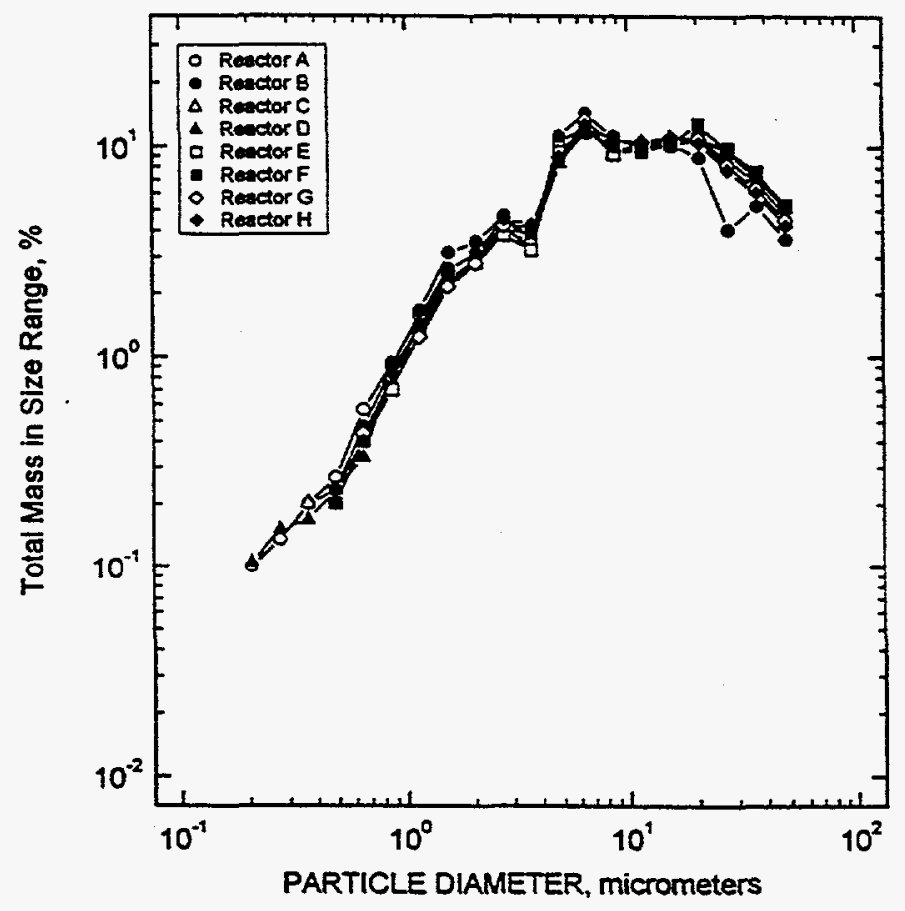

Figure 4-25. Differential Particle Size Distribution for Fly Ash Collected Downstream of the Third Reactor Level (High-Dust Reactors)

During Low-Load Tests 


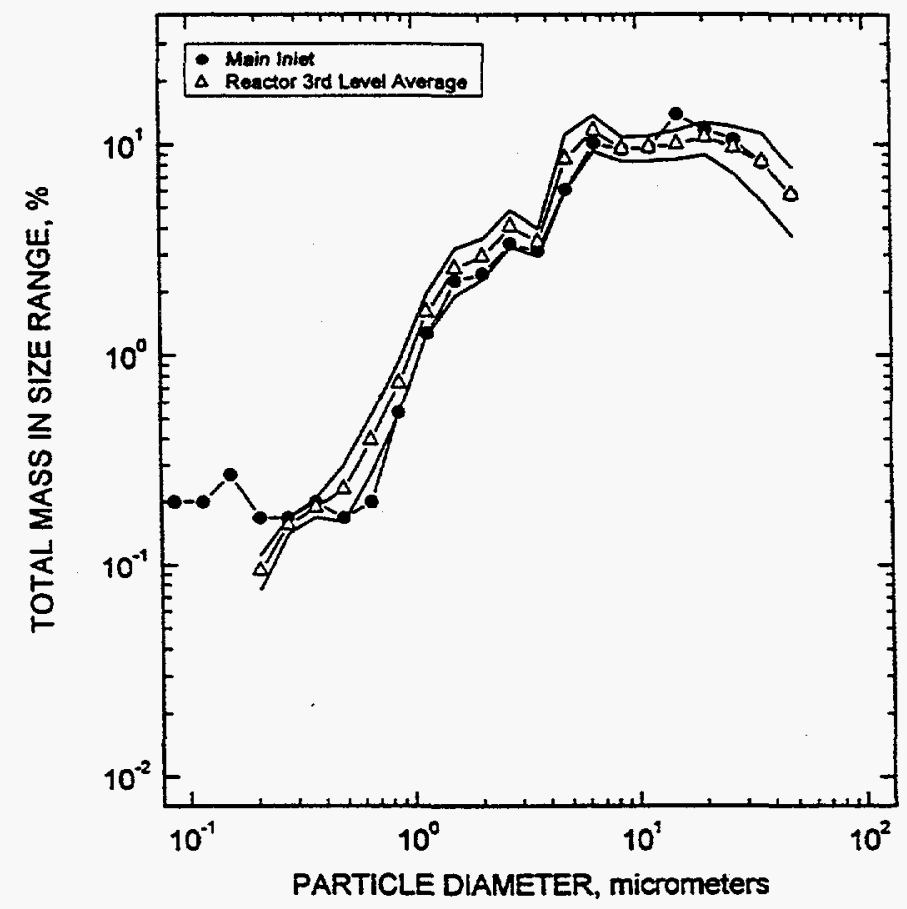

Figure 4-26. Comparison of Differential Particle Size Distributions: Hot-Side ESP Inlet and Average of High-Dust Reactors at High Load

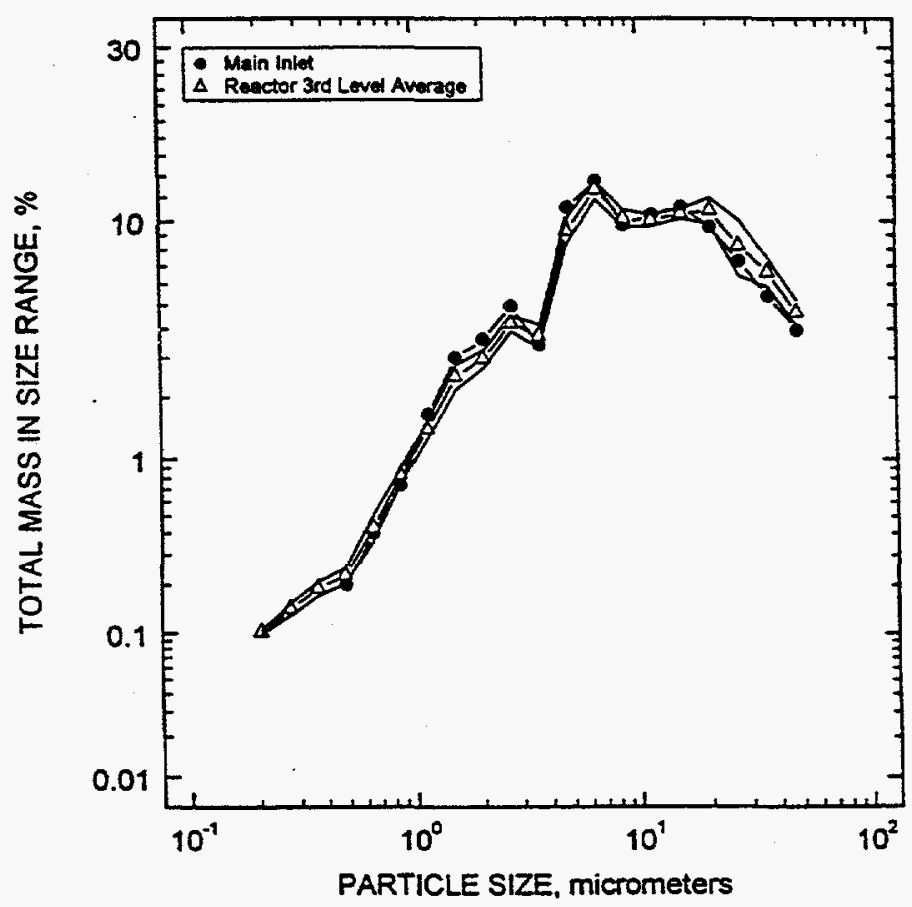

Figure 4-27. Comparison of Differential Particle Size Distributions: Hot-Side ESP. Inlet and Average of High-Dust Reactors at Low Load 
Table 4-7. Ash Minerals Analyses Summary

\begin{tabular}{||c|c|c|c|c|c|c|c|c||}
\hline \multirow{2}{*}{ Species } & \multicolumn{2}{|c|}{ As-Fired Coal } & \multicolumn{2}{c|}{ ESP Inlet } & \multicolumn{2}{c|}{ Reactor A Outlet } & \multicolumn{2}{c||}{ Reactor B Outlet } \\
\cline { 2 - 10 } & $\mathbf{1 0 F e b 9 3}$ & 11Feb93 & 9Feb93 & 10Feb93 & 25Apr94 & 8Nov94 & 02May94 & 9Nov94 \\
\hline \hline $\mathrm{SiO}_{2}$ & 44.3 & 47.4 & 48.9 & 48.4 & 48.0 & 47.59 & 49.3 & 47.58 \\
\hline $\mathrm{Al}_{2} \mathrm{O}_{3}$ & 22.6 & 22.5 & 22.7 & 22.7 & 22.2 & 23.73 & 22.3 & 24.77 \\
\hline $\mathrm{TiO}_{2}$ & 0.83 & 0.83 & 1.0 & 1.0 & 1.1 & 1.15 & 1.1 & 1.2 \\
\hline $\mathrm{Fe}_{2} \mathrm{O}_{3}$ & 19.9 & 20.6 & 17.8 & 18.1 & 18.7 & 16.81 & 18.5 & 16.82 \\
\hline $\mathrm{CaO}$ & 4.6 & 2.8 & 4.6 & 4.0 & 3.5 & 2.93 & 2.9 & 2.54 \\
\hline $\mathrm{MgO}$ & 0.91 & 0.78 & 0.97 & 0.97 & 0.98 & 0.91 & 1.0 & 1.06 \\
\hline $\mathrm{K}_{2} \mathrm{O}$ & 2.3 & 2.0 & 2.8 & 2.5 & 2.4 & 2.76 & 2.4 & 2.92 \\
\hline $\mathrm{Na}_{2} \mathrm{O}$ & 0.8 & 0.66 & 0.79 & 0.87 & 0.97 & 0.94 & 1.2 & 0.98 \\
\hline Others & 4.2 & 2.68 & 1.19 & 1.38 & 2.15 & 3.18 & 1.3 & 2.13 \\
\hline
\end{tabular}

\begin{tabular}{|c|c|c|c|c|c|}
\hline \multirow[b]{2}{*}{ Species } & \multirow{2}{*}{\begin{tabular}{|c|} 
Reactor C Outlet \\
26Apr94 \\
\end{tabular}} & \multicolumn{2}{|c|}{ APH A Outlet } & \multicolumn{2}{|c|}{ APH B Outlet } \\
\hline & & 25Apr94 & 8Nov94 & 2May94 & 9Nov94 \\
\hline $\mathrm{SiO}_{2}$ & 49.0 & 47.4 & 48.58 & 49.3 & 48.36 \\
\hline $\mathrm{Al}_{2} \mathrm{O}_{3}$ & 21.9 & 22.0 & 24.03 & 21.7 & 25.04 \\
\hline $\mathrm{TiO}_{2}$ & 0.91 & 1.1 & 1.15 & 0.91 & 1.24 \\
\hline $\mathrm{Fe}_{2} \mathrm{O}_{3}$ & 18.5 & 20.3 & 16.61 & 18.2 & 15.18 \\
\hline $\mathrm{CaO}$ & 3.3 & 3.7 & 2.98 & 2.9 & 2.51 \\
\hline $\mathrm{MgO}$ & 1.0 & 0.97 & 0.93 & 0.97 & 0.93 \\
\hline $\mathrm{K}_{2} \mathrm{O}$ & 2.5 & 2.2 & 2.81 & 2.5 & 2.96 \\
\hline $\mathrm{Na}_{2} \mathrm{O}$ & 0.91 & 0.91 & 0.96 & 1.1 & 1.04 \\
\hline Others $^{b}$ & 1.98 & 1.2 & 1.95 & 2.42 & 2.74 \\
\hline
\end{tabular}

${ }^{\mathrm{a}}$ Units: \% by weight.

${ }^{b}$ Others include $\mathrm{SO}_{2}, \mathrm{P}_{2} \mathrm{O}_{5}, \mathrm{Li}_{2} \mathrm{O}, \mathrm{SrO}, \mathrm{BaO}, \mathrm{MnO}$, and undetermined.

$\mathrm{APH}=$ Air preheater . 
Table 4-8. Trace Metals Concentrations in Ash Samples ${ }^{\mathrm{a}}$

\begin{tabular}{|c|c|c|c|c|c|c|c|c|c|c|}
\hline \multirow[b]{2}{*}{ Element } & \multicolumn{2}{|c|}{ ESP Inlet } & \multicolumn{2}{|c|}{ ESP Outlet } & \multicolumn{2}{|c|}{ Reactor A Inlet } & \multirow{2}{*}{$\begin{array}{c}\text { APH A Inlet } \\
\text { 8Nov94 } \\
\end{array}$} & \multirow{2}{*}{$\begin{array}{c}\text { APH A Outlet } \\
\text { 8Nov94 }\end{array}$} & \multirow{2}{*}{$\begin{array}{c}\text { APH B Inlet } \\
\text { 9Nov94 }\end{array}$} & \multirow{2}{*}{$\begin{array}{c}\text { APH B Outlet } \\
\text { 9Nov94 } \\
\end{array}$} \\
\hline & $\begin{array}{c}9 \text { Feb93 } \\
\text { High Load } \\
\end{array}$ & $\begin{array}{c}11 \text { Feb93 } \\
\text { Low Load } \\
\end{array}$ & $\begin{array}{c}9 \text { Feb93 } \\
\text { High Load } \\
\end{array}$ & $\begin{array}{c}11 \text { Feb93 } \\
\text { Low Load } \\
\end{array}$ & $\begin{array}{c}\text { 6Mar93 } \\
\text { High Load } \\
\end{array}$ & $\begin{array}{c}\text { 6Mar93 } \\
\text { Low Load } \\
\end{array}$ & & & & \\
\hline Antimony & 9 & 2.9 & $\leq 180.0$ & $<3.6$ & 6.1 & 8.3 & 15 & 12 & 12 & 17.3 \\
\hline Arsenic & 139 & 69.7 & 110 & 97.9 & 51.3 & 47.2 & 145 & 146 & 146 & 171 \\
\hline Barium & 298 & 377 & 339 & 563 & 302 & 259 & 305 & 357 & 455 & 431 \\
\hline Beryllium & 11.3 & 14.5 & $<35.0$ & 21 & 9.6 & 10.3 & 17.6 & 17.3 & 17.7 & 18.2 \\
\hline Cadmium & 5.9 & 10.3 & 39.1 & 20 & 4.6 & 7.2 & 4.3 & $<4.0$ & $<4.0$ & $<4.0$ \\
\hline Cesium & 85.5 & 74.6 & $<3500$ & $<80.0$ & 72.9 & 69.9 & $<33$ & $<32$ & $<32$ & $<31$ \\
\hline Chromium & 124 & 148 & 241 & 152 & 132 & 124 & 148 & 151 & 151 & 168 \\
\hline Cobalt & 23 & 30.6 & $<70.0$ & 30.7 & 27.4 & 22.8 & 50.6 & 50.1 & 53.8 & 54.1 \\
\hline Copper & 71.6 & 86.4 & 215 & 93.2 & 66.2 & 65.4 & 125 & 125 & 144 & 148 \\
\hline Lead & 221 & 286 & 426 & 404 & 227 & 239 & 298 & 227 & 277 & 319 \\
\hline Manganese & 152 & 172 & 226 & 174 & 225 & 169 & 173 & 168 & 158 & 160 \\
\hline Mercury & 0.35 & 0.13 & $<7.0$ & 0.21 & 0.12 & 0.18 & 0.019 & 0.63 & $<0.010$ & 1.29 \\
\hline Molybdenum & 72.9 & 77 & 880 & 85.7 & 82.6 & 74.6 & 26.3 & 25.2 & 25.3 & 27.8 \\
\hline Nickel & 86.5 & 104 & $<180$ & 106 & 100 & 89.5 & 156 & 157 & 167 & 179 \\
\hline Rubidium & 134 & 126 & $<1800$ & 125 & 132 & 123 & 93.2 & 117 & 155 & 142 \\
\hline Selenium & 99.3 & 8.02 & 514 & 13.7 & 1.37 & 7.1 & $<0.56$ & 3.7 & $<0.54$ & 6.7 \\
\hline Strontium & 186 & 237 & 228 & 252 & 188 & 175 & 472 & 546 & 766 & 736 \\
\hline Tin & 26.8 & 31.1 & $<180$ & 22.7 & 21.5 & 20 & 78.2 & 83.9 & 93.1 & 75.8 \\
\hline Vanadium & 683 & 458 & 577 & 428 & 467 & 531 & 348 & 348 & 368 & 380 \\
\hline Zinc & 311 & 647 & 3320 & 1118 & 436 & 353 & 247 & 252 & 227 & 241 \\
\hline
\end{tabular}

${ }^{a}$ Concentration units: $\mu \mathrm{g} / \mathrm{g}$ (ppmw). 
parameters are summarized in Tables 4-9 and 4-10 and Figures 4-28 through 4-30. Rather than analyzing for solid-phase ammonia compounds, SRI subjected samples of fly ash to extraction using buffered solutions.

As shown in Table 4-9, the ammonia concentration on the reactor inlet fly ash was below detectable levels, as expected. Ammonia was present, however, in the SCR reactor outlet fly ash samples. Table 4-9 and Figure 4-28 show that the amount of ammonia on the post-SCR reactor fly ash increased as the $\mathrm{NH}_{3} / \mathrm{NO}_{\mathrm{x}}$ ratio increased.

Table 4-10 and Figures 4-29 and 4-30 show that the ammonia concentration was much higher in the smaller particle sizes of fly ash, but most of the total ammonia was found to reside with the large particles simply because these comprised the vast majority of the fly ash mass.

\section{Toxicity Characteristic Leaching Procedure (TCLP) Applied to Fly Ash Testing}

Composite samples of the SCR inlet flue gas fly ash (collected from the host unit's hotside ESP hopper) and the SCR reactor outlet gas fly ash (collected as grab samples from the cyclone ash hoppers following each of the high dust SCR reactors) were leached and analyzed for the suite of toxic metals found in the U.S. EPA's TCLP Method, as described in RCRA Subpart C Hazardous Waste Determination regulations. Composite samples were prepared from the individual reactor ash samples. Table 4-11 indicates the reactors from which each set of composite samples was prepared. As shown in Table 4-11, the metals concentrations in the TCLP leachate from all of the samples were much lower than the RCRA limits. Most of the metals were not present above method detection limits; very low concentrations of barium, cadmium, and chromium were measured in some of the samples. Based on these results, the sampled solids would not be considered hazardous wastes under the RCRA Toxicity Characteristic, with respect to toxic metals.

\subsection{Long-Term Monitoring Results}

Long-term monitoring was conducted using continuous on-line monitors for the following parameters and streams: $\mathrm{NO}_{\mathrm{x}}$ and $\mathrm{O}_{2}$ in the $\mathrm{SCR}$ reactor inlet and outlet gas streams and $\mathrm{SO}_{2}$ and $\mathrm{CO}$ in the SCR reactor inlet gas. Oxygen monitoring was performed to allow normalization of the pollutant concentrations. 
Table 4-9. Ammonia Concentrations in Flue Gas Particulates

\begin{tabular}{||c|c|c|c|c|c||}
\hline \multicolumn{2}{|c|}{ SCR Reactor Target Operating Conditions } & \multicolumn{3}{c|}{ Average $\mathbf{N H}_{\mathbf{3}}$ Concentration, $\mu \mathrm{g} / \mathrm{g}$} \\
\hline Temp., ${ }^{\circ} \mathbf{F}$ & Flow/Design & $\mathbf{N H}_{3} / \mathbf{N O}_{r}$ & $\begin{array}{c}\text { Reactor Inlet } \\
\text { (Isokinetic) }\end{array}$ & $\begin{array}{c}\text { APH Outlet } \\
\text { (Isokinetic) }\end{array}$ & $\begin{array}{c}\text { APH Ash } \\
\text { Hopper }\end{array}$ \\
\hline \hline 700 & 1.0 & 0.6 & $<6$ & 86 & 49 \\
\hline 700 & 1.0 & 0.8 & $<6$ & 199 & 244 \\
\hline 700 & 1.0 & 1.0 & $<6$ & 812 & 351 \\
\hline
\end{tabular}

Table 4-10. Size Dependency of Air Preheater Outlet Particulate Ammonia Concentration

\begin{tabular}{|c|c|c|c|}
\hline Cyclone Stage & $\begin{array}{c}\text { Average Aerodynamic } \\
\mathbf{D}_{\mathbf{5},}, \mu \mathrm{m}\end{array}$ & $\begin{array}{c}\text { Average Particle } \\
\text { Mass, } \mathbf{g}\end{array}$ & $\begin{array}{c}\text { Average } \mathbf{N H}_{\mathbf{3}} \\
\text { Conc., } \mu \mathrm{g} / \mathbf{g}\end{array}$ \\
\hline \hline 1 & 7.710 & 5.130 & 24 \\
\hline 2 & 4.335 & 0.644 & 102 \\
\hline 3 & 2.366 & 0.202 & 194 \\
\hline 4 & 1.638 & 0.085 & 412 \\
\hline 5 & 0.688 & 0.0079 & 734 \\
\hline
\end{tabular}

Note: Target operating conditions: Temperature $=700^{\circ} \mathrm{F} ;$ Flow $/$ Design $=1.0 ; \mathrm{NH}_{3} / \mathrm{NO}_{\mathrm{x}}$ ratio $=0.8$ 


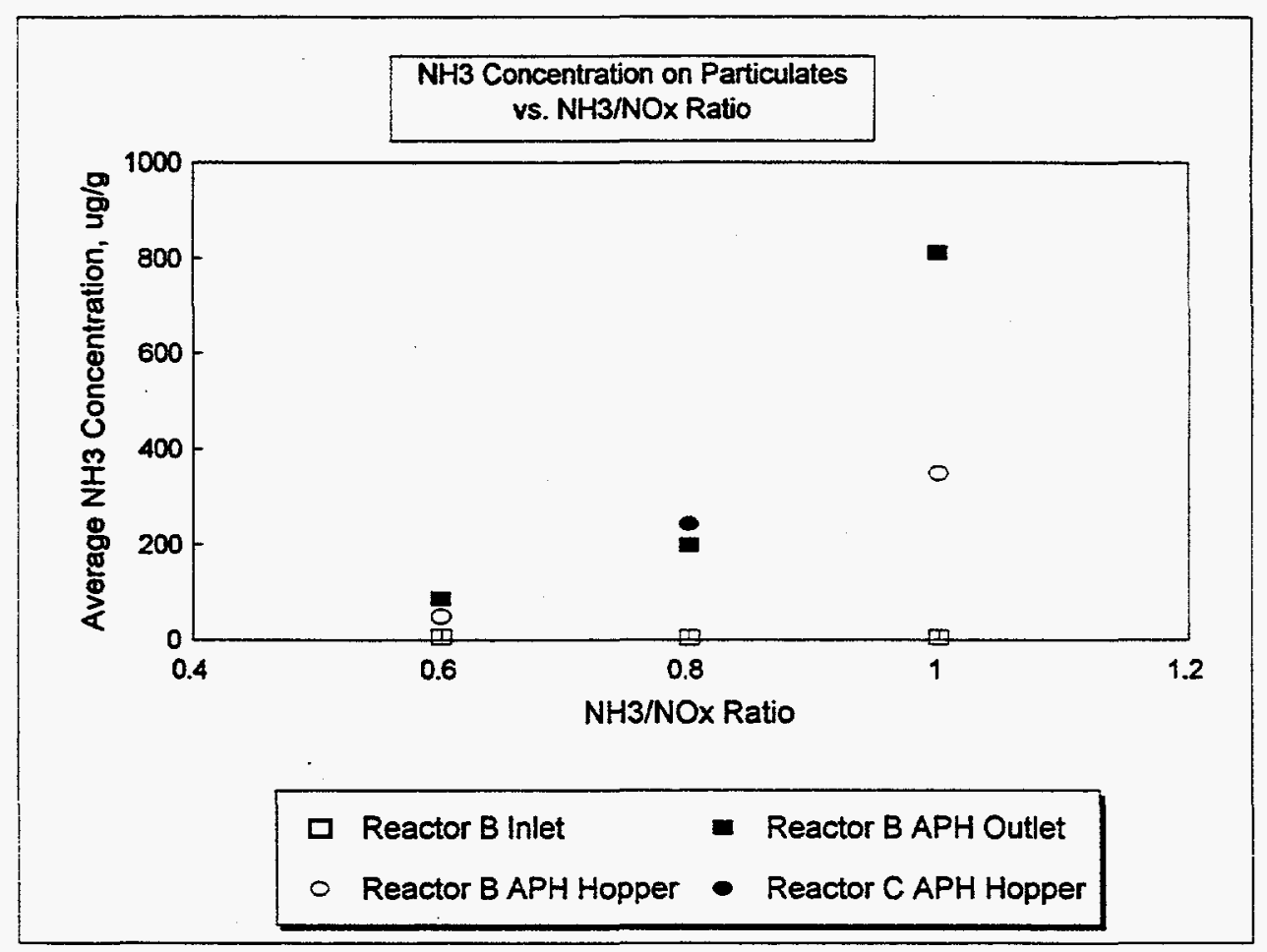

Figure 4-28. Variation in Ammonia Concentration on Flue Gas Particulate Matter with $\mathrm{NH}_{3}$-to- $\mathrm{NO}_{\mathrm{x}}$ Ratio

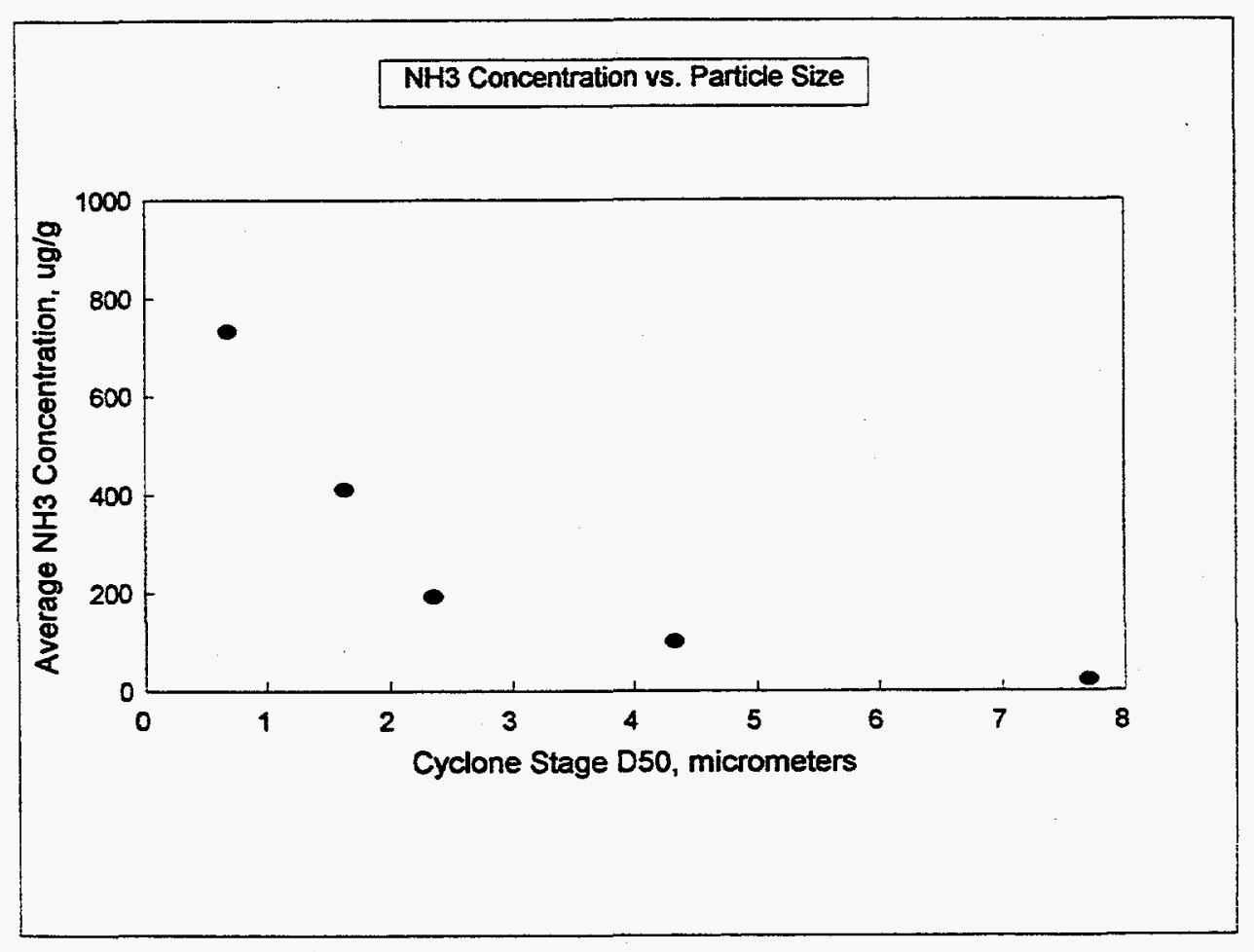

Figure 4-29. Variation in Ammonia Concentration on Flue Gas Particulate Matter with Particle Size 


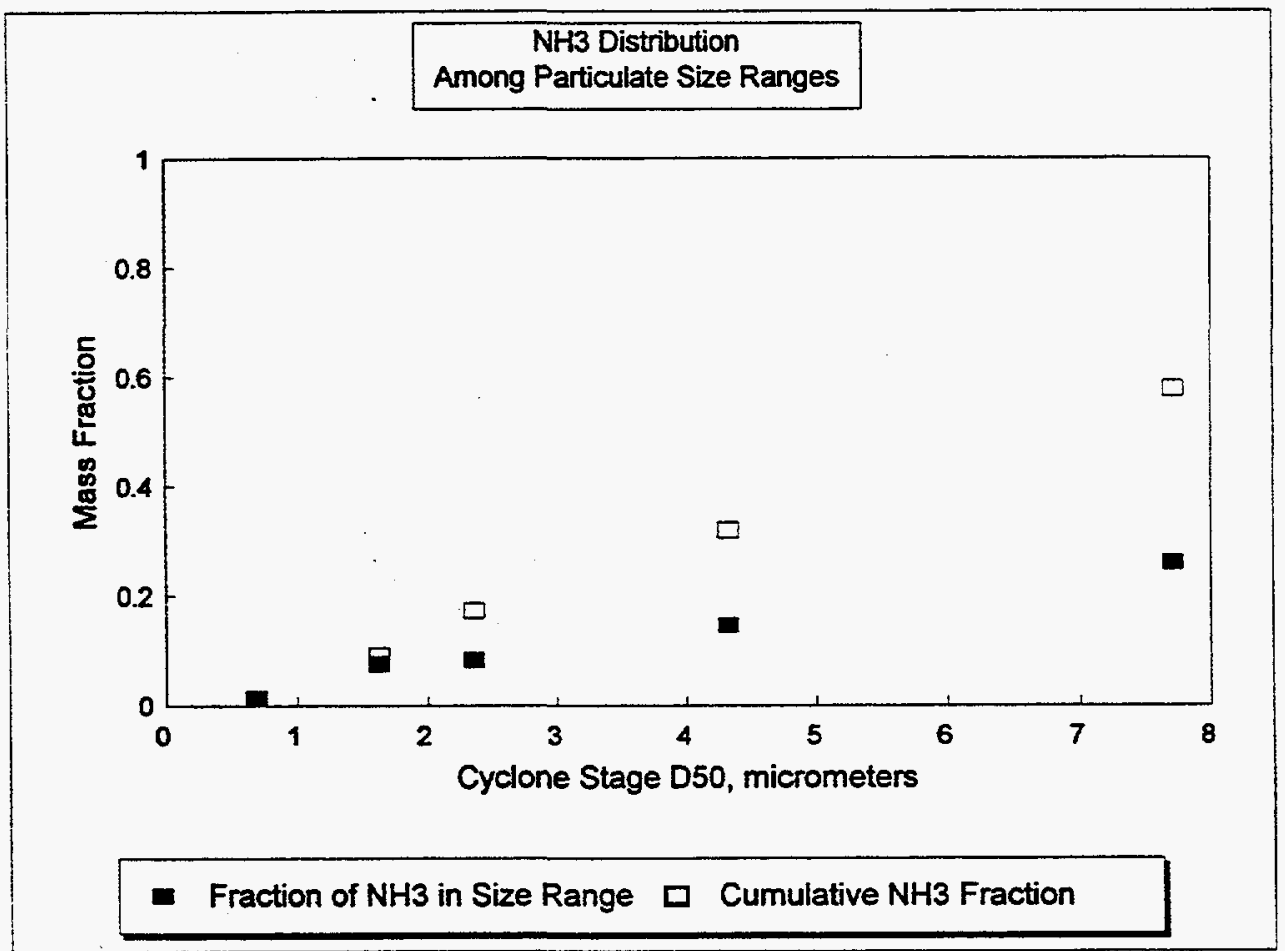

Figure 4-30. Mass Fraction of Ammonia on Flue Gas Particulate Matter Versus Particle Size 
Table 4-11. Results of TCLP Metals Analyses: SCR Reactor Solids

\begin{tabular}{|c|c|c|c|c|c|c|c|c|c|}
\hline \multirow[b]{2}{*}{ Date } & \multirow[b]{2}{*}{ Sample Description } & \multicolumn{8}{|c|}{ TCLP Leachate Analysis, mg/L } \\
\hline & & $\mathbf{A g}$ & As & Ba & $\mathbf{C d}$ & $\mathbf{C r}$ & $\mathrm{Hg}$ & $\mathbf{P b}$ & Se \\
\hline \multirow[t]{2}{*}{ 21Jun93 } & SCR Inlet & $<0.5$ & $<0.5$ & $<10$ & $<0.1$ & $<0.5$ & $<0.002$ & $<0.5$ & $<0.1$ \\
\hline & SCR Reactor Outlet (A, B, C Composite) & $<0.5$ & $<0.5$ & $<10$ & $<0.1$ & $<0.5$ & $<0.002$ & $<0.5$ & $<0.1$ \\
\hline 28Jun93 & SCR Reactor Outlet (A, B, C, D, E, F, G, H Composite) & $<0.5$ & $<0.5$ & $<10$ & $<0.1$ & $<0.5$ & $<0.002$ & $<0.5$ & $<1$ \\
\hline \multirow[t]{3}{*}{ 25Aug94 } & SCR Inlet & $<0.01$ & $<0.05$ & 0.30 & 0.024 & 0.04 & $<0.002$ & 0.05 & $<0.1$ \\
\hline & SCR Reactor Outlet (A, B, C Composite) & $<0.01$ & $<0.05$ & 0.33 & 0.02 & 0.08 & $<0.002$ & 0.05 & $<0.1$ \\
\hline & SCR Reactor Outlet (D, E, F, G Composite) & $<0.01$ & $<0.05$ & 0.29 & 0.015 & 0.04 & $<0.002$ & 0.05 & $<0.1$ \\
\hline \multirow[t]{5}{*}{ 12Jul95 } & SCR Inlet & $<0.01$ & $<0.05$ & 0.24 & 0.024 & 0.01 & $<0.002$ & $<0.05$ & $<0.1$ \\
\hline & SCR Reactor Outlet (A, B, C Composite) & $<0.01$ & $<0.05$ & 0.24 & $<0.005$ & $<0.01$ & $<0.002$ & $<0.05$ & $<0.1$ \\
\hline & SCR Reactor Outlet (D, E, F Composite) & $<0.01$ & $<0.05$ & 0.24 & $<0.005$ & $<0.01$ & $<0.002$ & $<0.05$ & $<0.1$ \\
\hline & SCR Reactor Outlet (G, H Composite) & $<0.01$ & $<0.05$ & 0.23 & $<0.005$ & $<0.01$ & $<0.002$ & $<0.05$ & $<0.1$ \\
\hline & RCRA Limits & 5.0 & 5.0 & 100.0 & 1.0 & 5.0 & 0.2 & 5.0 & 1.0 \\
\hline
\end{tabular}




\subsubsection{Nitrogen Oxides $\left(\mathrm{NO}_{x}\right)$}

Quarterly average flue gas flow rate, $\mathrm{NH}_{3} / \mathrm{NO}_{\mathrm{x}}$ ratio, $\mathrm{NO}_{\mathrm{x}}$ concentration data for the inlet flue gas and the outlet of each SCR reactor, and $\mathrm{NO}_{\mathrm{x}}$ reduction efficiencies are provided in Table 4-12. The values shown represent averages over all operating periods in each quarter, including periods when parametric tests were conducted. The interpretation of these results is not within the scope of the EMP, but is provided in the final SCR demonstration project report (1).

\subsubsection{Carbon Monoxide (CO)}

The monthly average carbon monoxide concentrations in the SCR reactor inlet gas are plotted versus time in Figure 4-31. With the exception of September and October 1993, the monthly average flue gas $\mathrm{CO}$ concentration was relatively consistent at 14-18 ppmv.

\subsubsection{Sulfur Dioxide $\left(\mathrm{SO}_{2}\right)$}

The monthly sulfur dioxide concentrations in the SCR reactor inlet flue gas are plotted versus time in Figure 4-32. The monthly average $\mathrm{SO}_{2}$ concentration varied from about 600 to $1800 \mathrm{ppmv}$. As shown previously, the variability in flue gas $\mathrm{SO}_{2}$ concentration was due to changes in the coal sulfur content. 
Table 4-12. Long-Term SCR Reactor Inlet and Outlet $\mathrm{NO}_{x}$ Concentrations and Reductions Across SCR Reactors

\begin{tabular}{|c|c|c|c|c|c|c|c|c|c|c|c|c|c|}
\hline Perind & Reactor & $\begin{array}{l}\text { Flow } \\
\text { Rate } \\
\text { scfm } \\
\end{array}$ & $\begin{array}{c}\mathrm{NH}_{3} / \mathrm{NO}_{\mathbf{x}} \\
\text { Ratio } \\
\end{array}$ & $\begin{array}{c}\text { Inlet NO } \\
\text { npmy } \\
\end{array}$ & $\begin{array}{l}\text { Outlet } \\
\text { No } \\
\text { nnmy } \\
\text { nnme }\end{array}$ & $\begin{array}{c}N_{x} \\
\text { Red'n } \\
\% \\
\end{array}$ & Period & Reactor & $\begin{array}{c}\text { Flow Rate } \\
\text { scfim }\end{array}$ & $\begin{array}{r}\mathrm{NH}_{3} / \mathrm{NO}_{\mathbf{x}} \\
\text { Ratio } \\
\end{array}$ & $\begin{array}{c}\text { Inlet } \mathrm{NO}_{\mathrm{x}} \\
\mathrm{ppm \textrm {my }}\end{array}$ & $\begin{array}{l}\text { Outlet } \\
\text { No } \\
\text { npmx }\end{array}$ & $\begin{array}{c}\text { NO } \\
\% \\
\%\end{array}$ \\
\hline \multirow[t]{8}{*}{ Oct-Dec 93} & $\mathrm{~A}$ & 4,991 & 0.77 & 373 & 35 & 88 & \multirow[t]{8}{*}{ Oct-Dec 94} & $\mathrm{~A}$ & 4,945 & 0.79 & 379 & 49 & 86 \\
\hline & B & 4,969 & 0.77 & 364 & 33 & 90 & & $\bar{B}$ & 4,987 & 0.79 & 377 & 48 & 85 \\
\hline & $\mathrm{C}$ & 4,945 & 0.77 & 359 & 65 & 80 & & $\mathrm{C}$ & 4,946 & 0.79 & 388 & 50 & 85 \\
\hline & $\mathrm{D}$ & 392 & 0.79 & 340 & 45 & 84 & & $\mathrm{D}$ & 400 & 0.79 & 383 & 34 & 89 \\
\hline & $E$ & 393 & 0.77 & 358 & 38 & 86 & & $E$ & 400 & 0.79 & 386 & 41 & 88 \\
\hline & $F$ & 378 & 0.78 & 353 & 45 & 85 & & F & 401 & 0.79 & 382 & 46 & 86 \\
\hline & G & - & - & - & - & - & & $G$ & 402 & 0.79 & 391 & 44 & 85 \\
\hline & $\mathrm{J}$ & - & - & - & - & $=$ & & $\mathrm{J}$ & 404 & 0.76 & 398 & 69 & 79 \\
\hline \multirow[t]{8}{*}{ Jan-Mar 94} & $A$ & 5,000 & 0.76 & 348 & 71 & 76 & \multirow[t]{8}{*}{ Jan-Mar 95} & $\mathrm{~A}$ & 4,974 & 0.79 & 404 & 48 & 88 \\
\hline & $\mathrm{B}$ & 5,070 & 0.77 & 344 & 71 & 76 & & B & 4,954 & 0.79 & 399 & 32 & 89 \\
\hline & $\mathrm{C}$ & 5,101 & 0.77 & 348 & 75 & 75 & & C & 4,967 & 0.79 & 410 & 32 & 89 \\
\hline & D & 399 & 0.77 & 345 & 68 & 73 & & $\mathrm{D}$ & 404 & 0.80 & 423 & 38 & 89 \\
\hline & $E$ & 391 & 0.75 & 343 & 76 & 73 & & $E$ & 400 & 0.79 & 413 & 77 & 80 \\
\hline & $F$ & 398 & 0.76 & 346 & 81 & 71 & & $F$ & 400 & 0.78 & 404 & 43 & 88 \\
\hline & G & - & - & - & - & - & & $\mathrm{G}$ & 400 & 0.79 & 420 & 66 & 81 \\
\hline & $\mathrm{J}$ & - & - & - & - & - & & $\mathrm{J}$ & 399 & 0.75 & 422 & 26 & 88 \\
\hline \multirow[t]{8}{*}{ Apr-Jun 94} & $\mathrm{~A}$ & 4,992 & 0.78 & 347 & 66 & 78 & \multirow[t]{8}{*}{ Apr-Jul 95} & A & 5,540 & 0.76 & 340 & 61 & 80 \\
\hline & B & 4,963 & 0.77 & 359 & 64 & 81 & & B & 5,128 & 0.80 & 338 & 51 & 83 \\
\hline & $\mathrm{C}$ & 5,000 & 0.78 & 354 & 59 & 81 & & C & 5,233 & 0.71 & 345 & 42 & 85 \\
\hline & D & 404 & 0.78 & 345 & 78 & 77 & & $\mathrm{D}$ & 359 & 0.79 & 336 & 64 & 78 \\
\hline & $\mathrm{E}$ & 402 & 0.78 & 331 & 52 & 82 & & $E$ & 431 & 0.66 & 338 & 109 & 62 \\
\hline & $F$ & 402 & 0.76 & 354 & 56 & 78 & & $F$ & 391 & 0.66 & 334 & 69 & 75 \\
\hline & $\mathrm{G}$ & 399 & 0.8 & 345 & 51 & 80 & & $\bar{G}$ & 462 & 0.58 & 323 & 111 & 46 \\
\hline & $\mathrm{J}$ & - & - & - & - & - & & $\mathbf{J}$ & 395 & 0.61 & 333 & 87 & 60 \\
\hline \multirow[t]{8}{*}{\begin{tabular}{|l|} 
Jul-Sep 94 \\
\end{tabular}} & $\mathrm{~A}$ & 4,974 & 0.78 & 376 & 82 & 77 & \multirow{8}{*}{\multicolumn{7}{|c|}{$\begin{array}{l}\text { Notes: } \\
\text { (1) Continuous monitoring data not available prior to the fourth quarter of } 1993 \\
\text { (2) Data not available for Reactor } G \text { until second quarter } 1994 \text { due to catalyst damage } \\
\text { and change out. } \\
\text { (3) Data not available for Reactor J until third quarter } 1994 \text { due to withdrawal of } \\
\text { catalyst supplier participant and subsequent supplier replacement change out. } \\
\text { (4) All data corrected for oxygen variations. }\end{array}$}} \\
\hline & B & 5,050 & 0.78 & 370 & 63 & 81 & & & & & & & \\
\hline & $C$ & 5,090 & 0.78 & 368 & 46 & 86 & & & & & & & \\
\hline & $\mathrm{D}$ & 401 & 0.80 & 360 & 22 & 92 & & & & & & & \\
\hline & $E$ & 406 & 0.80 & 359 & 42 & 86 & & & & & & & \\
\hline & $F$ & 401 & 0.76 & 366 & 35 & 86 & & & & & & & \\
\hline & G & 401 & 0.79 & 359 & 47 & 84 & & & & & & & \\
\hline & 1 & 398 & 076 & 386 & 106 & 71 & & & & & & & \\
\hline
\end{tabular}




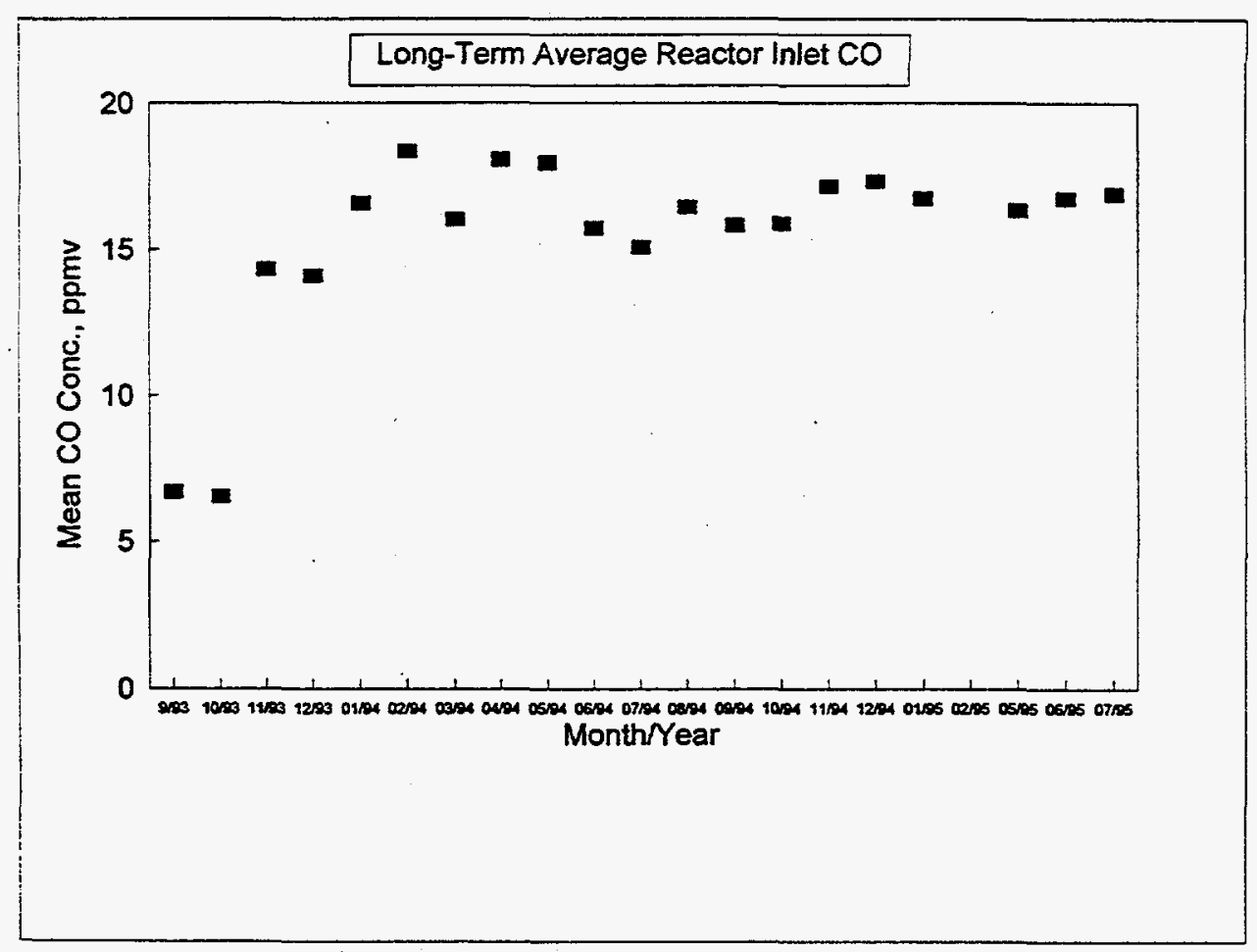

Figure 4-31. Monthly Average Reactor Inlet CO Concentration During the SCR Demonstration Project

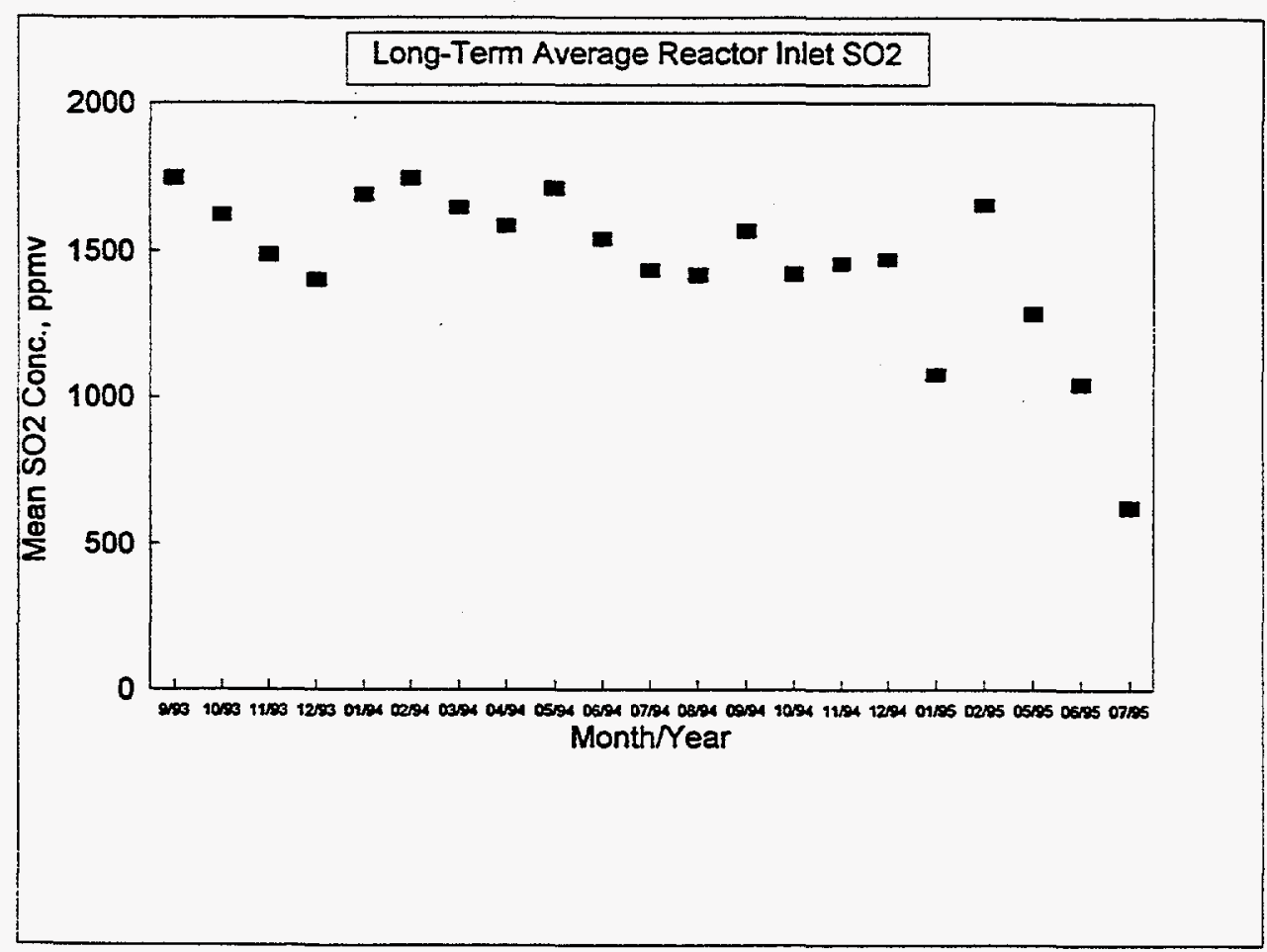

Figure 4-32. Monthly Average Reactor Inlet $\mathrm{SO}_{2}$ Concentration During the SCR Demonstration Project 


\subsection{Aqueous Stream Monitoring Results}

Aqueous stream monitoring was conducted on two streams: supplemental monitoring of the air preheater wash water (associated with the SCR reactor air preheaters) and compliance monitoring of the ash pond discharge stream. The results for each stream are summarized below.

\subsection{Supplemental Monitoring}

The air preheaters were washed several times during the program, and the wash water was sampled during these episodes. Because of the equipment configuration, however, it was very difficult to collect samples, during the in-situ washes, that were considered to be representative of the wash water that would be produced in a commercial unit. As a result, most of the wash water samples were not analyzed. During one wash cycle, however, the air preheater baskets were removed and washed, allowing much greater control of the wash water sample collection. The water samples collected during this wash cycle were analyzed, and the results are summarized in Table 5-1. Samples were obtained at the beginning and end of the wash cycle, which was performed using plant clear water (well water). Of note are the decrease in iron, sulfate, and fluoride concentrations and the increase in $\mathrm{pH}$ and chloride ion concentrations over the course of the wash cycle.

Table 5-1. Air Preheater Wash Water Analyses

\begin{tabular}{|l|c|c|c|}
\hline \multicolumn{1}{|c|}{ Parameter } & Units & $\begin{array}{c}\text { Feb 9, 1995 } \\
\mathbf{1 : 0 0} \text { p.m. }\end{array}$ & $\begin{array}{c}\text { Feb 9, 1995 } \\
\text { 3:00 p.m. }\end{array}$ \\
\hline $\mathrm{pH}$ & $\mathrm{S} . \mathrm{U}$. & 2.97 & 4.78 \\
\hline Iron & $\mathrm{mg} / \mathrm{L}$ & 49.7 & 0.54 \\
\hline Fluoride & $\mathrm{mg} / \mathrm{L}$ & 0.12 & $<0.1$ \\
\hline Chloride & $\mathrm{mg} / \mathrm{L}$ & 3.50 & 8.25 \\
\hline Sulfate & $\mathrm{mg} / \mathrm{L}$ & 728.0 & 6.02 \\
\hline
\end{tabular}

\subsection{Compliance Monitoring}

Of the existing permitted aqueous discharge streams at Plant Crist, the only one that could possibly have been affected by the SCR demonstration project was the ash pond discharge stream. The parameters and schedule for compliance monitoring of this stream are specified in 
U.S. EPA NPDES Permit No. FL0002275 and in the State of Florida Department of Environmental Regulation Operating Permit No. IO17-109985. Table 5-2 summarizes the results of ash pond discharge monitoring conducted during the period of the SCR demonstration: January 1993 through July 1995. These data were taken from Discharge Monitoring Reports submitted by Gulf Power Co. in compliance with permit requirements. As shown, the only exceedances of ash pond discharge permit limits occurred during the December 1994 and July 1995 monitoring periods.

In December 1994, the $\mathrm{pH}$ was lower than 6.0 for a period of approximately four hours during a wash cycle of the Unit 5 air preheater. During this excursion, the measured $\mathrm{pH}$ of the main plant discharge remained above the permit limit of 6.0. In July 1995, the total suspended solids exceeded both monthly average and daily maximum limits; this was caused by excessive rainfall. In August 1995, the measured TSS level was below the permit limits. Neither of these exceedances was related to operation of the SCR demonstration unit. 
Table 5-2. Ash Pond Discharge Monitoring Summary

\begin{tabular}{|c|c|c|c|c|c|c|}
\hline \multirow[b]{2}{*}{ Month/Year } & \multicolumn{2}{|c|}{ pH, S. U. } & \multicolumn{2}{|c|}{ TSS, mg/L } & \multicolumn{2}{|c|}{ Oil \& Grease, mg/L } \\
\hline & Minimum & Maximum & $\begin{array}{l}\text { Monthly } \\
\text { Average }\end{array}$ & Maximum & $\begin{array}{l}\text { Monthly } \\
\text { Average }\end{array}$ & Maximum \\
\hline Jan 1993 & 6.62 & 9.30 & 3.9 & 5.6 & $<1.0$ & $<1.0$ \\
\hline Feb 1993 & 6.55 & 9.95 & 8.3 & 22.0 & $<1.0$ & $<1.0$ \\
\hline Mar 1993 & 6.53 & 9.85 & 8.5 & 19.0 & $<1.0$ & $<1.0$ \\
\hline Apr 1993 & 7.63 & 9.26 & 3.9 & 7.2 & $<1.0$ & $<1.0$ \\
\hline May 1993 & 7.80 & 8.73 & 4.2 & 7.0 & $<1.0$ & $<1.0$ \\
\hline Jun 1993 & 6.58 & 9.83 & 2.0 & 2.6 & $<1.0$ & $<1.0$ \\
\hline Jul 1993 & 6.37 & 9.50 & 3.4 & 8.2 & $<1.0$ & $<1.0$ \\
\hline Aug 1993 & 6.50 & 8.62 & 3.3 & 6.4 & $<1.0$ & $<1.0$ \\
\hline Sep 1993 & 7.50 & 9.43 & 3.6 & 8.2 & 1.0 & 1.0 \\
\hline Oct 1993 & 7.00 & 9.60 & 12.1 & 34.1 & $<1.0$ & $<1.0$ \\
\hline Nov 1993 & 6.41 & 9.00 & 5.7 & 10.0 & $<1.0$ & $<1.0$ \\
\hline Dec 1993 & 6.70 & 9.78 & 2.7 & 4.4 & $<1.0$ & $<1.0$ \\
\hline Jan 1994 & 6.45 & 8.13 & 7.2 & 22.0 & $<1.0$ & $<1.0$ \\
\hline Feb 1994 & 6.41 & 9.90 & 17.6 & 32.0 & $<1.0$ & $<1.0$ \\
\hline Mar 1994 & 6.29 & 9.79 & 17.9 & 59.0 & $<1.0$ & $<1.0$ \\
\hline Apr 1994 & 6.75 & 9.13 & 3.5 & 4.2 & $<1.0$ & $<1.0$ \\
\hline May 1994 & 6.87 & 9.76 & 6.7 & 16.0 & $<1.0$ & $<1.0$ \\
\hline Jun 1994 & 6.64 & 9.91 & 2.6 & 3.6 & $<1.0$ & $<1.0$ \\
\hline Jul 1994 & 6.43 & 9.38 & 4.7 & 5.6 & $<1.0$ & $<1.0$ \\
\hline Aug 1994 & 6.90 & 9.53 & 2.7 & 4.0 & $<1.0$ & $<1.0$ \\
\hline Sep 1994 & 6.57 & 9.69 & 4.0 & 7.2 & $<1.0$ & $<1.0$ \\
\hline Oct 1994 & 6.86 & 9.99 & 3.1 & 5.4 & $<1.0$ & $<1.0$ \\
\hline Nov 1994 & 6.55 & 9.47 & 2.8 & 4.2 & $<1.0$ & $<1.0$ \\
\hline Dec 1994 & $4.60^{\mathrm{a}}$ & 10.17 & 3.0 & 5.2 & $<1.0$ & $<1.0$ \\
\hline $\operatorname{Jan} 1995$ & 6.67 & 10.20 & 3.6 & 4.8 & $<1.0$ & $<1.0$ \\
\hline Feb 1995 & 6.88 & 10.42 & 10.2 & 24.0 & $<1.0$ & $<1.0$ \\
\hline Mar 1995 & 6.94 & 9.87 & 7.1 & 17.0 & $<1.0$ & $<1.0$ \\
\hline Apr 1995 & 6.40 & 9.54 & 8.9 & 19.0 & $<1.0$ & $<1.0$ \\
\hline May 1995 & 6.91 & 9.75 & 9.6 & 15.0 & $<1.0$ & $<1.0$ \\
\hline Jun 1995 & 7.46 & 10.00 & 2.8 & 4.0 & $<1.0$ & $<1.0$ \\
\hline Jul 1995 & 8.20 & 9.51 & $51.6^{b}$ & $200.0^{b}$ & $<1.0$ & $<1.0$ \\
\hline Permit Limits & 6.0 & 10.5 & 30.0 & 73.0 & 7.0 & 11.0 \\
\hline
\end{tabular}

${ }^{\mathrm{a}}$ Exceeded during Unit 5 air preheater wash. Returned to $>6.0$ within four hours. Measured $\mathrm{pH}$ of main plant discharge remained $>6.0$.

${ }^{b}$ High due to 5.5 inches of rainfall on sampling date. Subsequent samples collected August 1 and August 9, 1995:

$8.8 \mathrm{mg} / \mathrm{L}$ and $11 \mathrm{mg} / \mathrm{L}$, respectively.

Source: Discharge Monitoring Reports submitted by Gulf Power Co. 


\subsection{Solid Stream Monitoring Results}

The coal feed to the Unit 5 boiler was the only solid stream monitored during the SCR demonstration project (with the exception of the fly ash streams discussed previously in the gas stream monitoring section). Table 6-1 presents a statistical summary of the coal ultimate analyses and chlorine measurements conducted during the SCR demonstration project's testing phase. The statistics shown were calculated based on the monthly average data shown in Appendix A, Table A-12. These data were obtained from Southern Company Services' Final Report (2). Relative variations were highest for chlorine and sulfur content.

Table 6-1. Coal Monitoring Results

\begin{tabular}{|l|c|c|c|c|}
\hline \multicolumn{1}{|c|}{ Parameter } & Units & Mean & Std. Dev. & Range \\
\hline \hline Carbon & wt \% & 74.82 & 0.81 & $73.29-77.40$ \\
\hline Hydrogen & wt \% & 5.00 & 0.07 & $4.81-5.11$ \\
\hline Nitrogen & wt \% & 1.58 & 0.03 & $1.52-1.66$ \\
\hline Sulfur & wt \% & 2.58 & 0.40 & $1.14-3.02$ \\
\hline Ash & wt \% & 9.30 & 0.63 & $7.75-10.55$ \\
\hline Oxygen & wt \% & 6.73 & 0.66 & $5.53-7.98$ \\
\hline Chlorine & ppmw & 1767 & 812 & $185-3403$ \\
\hline
\end{tabular}




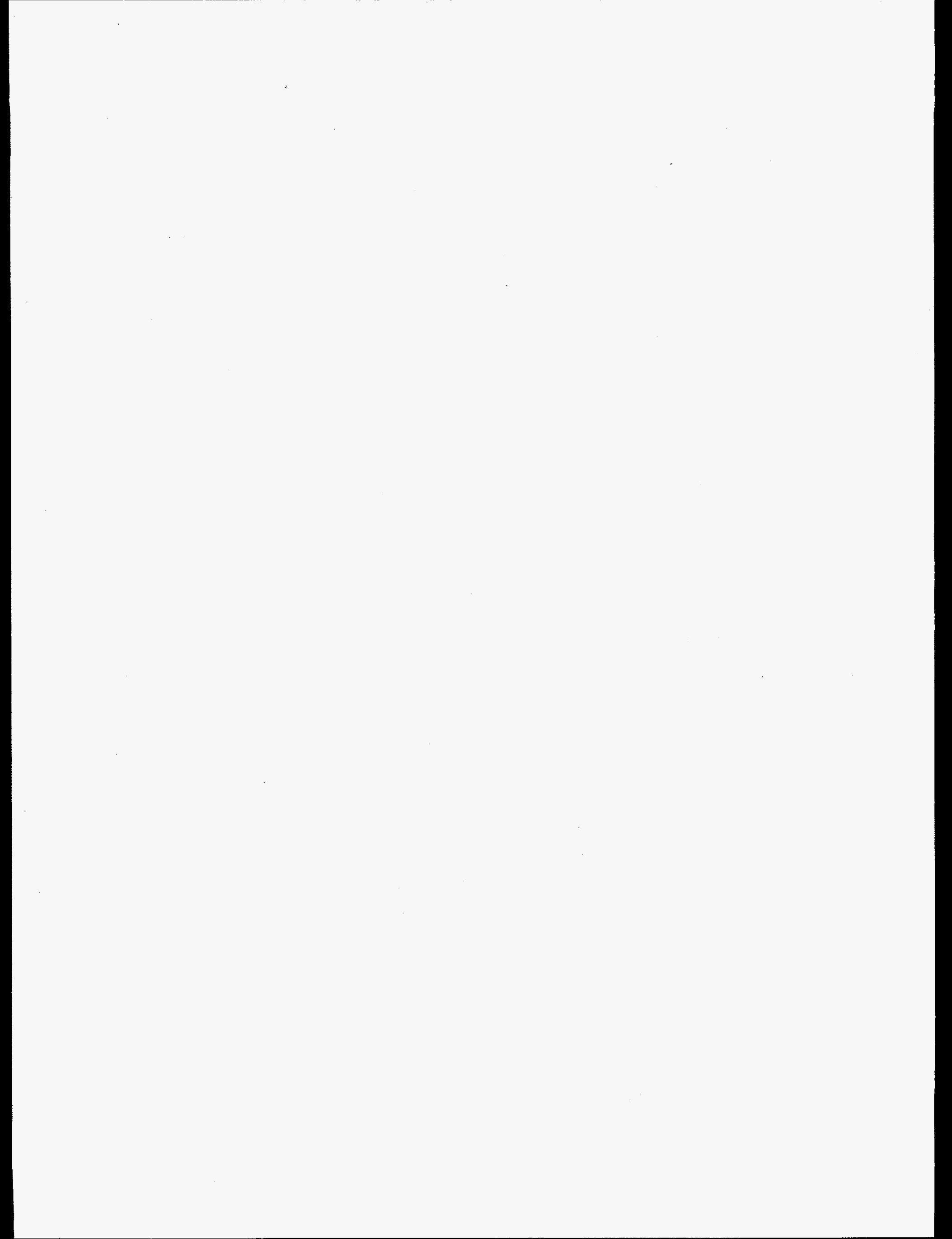




\subsection{Health and Safety Considerations}

Anhydrous ammonia was stored and used at Plant Crist during this program. The ammonia was stored in a 1000-gallon tank with a maximum fill level of 850 gallons. This tank was constructed in accordance with the ASME Code for Unfired Pressure Vessels (Section VIII), and was inspected, tested, and certified by an inspector qualified by the National Board of Boiler and Pressure Vessel Inspectors prior to shipment to Plant Crist.

The tank was equipped with a dual safety relief valve system. The storage tank was segregated from plant personnel, i.e., it was located in an area that was not frequented by plant personnel. The area was equipped with safety showers that were inspected on a monthly schedule. Material Safety Data Sheets for ammonia were included in all the design documents and in the plant safety program.

Plant Crist employed design, construction, and operating practices that met or exceeded industry standards for storing and handling anhydrous ammonia. Ammonia leak detection equipment was readily available, and water wash stations were located near the storage tank. The procurement, installation, loading, and unloading of the ammonia storage tank was handled by an experienced, licensed contractor. The transfer of liquid ammonia to the tank, and the displacement of vapor back to the truck was accomplished in a closed loop fashion, and no emissions were detected during these transfers. Metering and dilution of the ammonia was performed within an existing, unused stack for personnel protection.

These measures were very effective in preventing any spills or significant leaks of the ammonia. One small leak occurred in the area of the storage tanks. This leak, due to a poor hose connection, happened during the transfer of ammonia from the delivery truck to the storage tank. The operator saw the leak almost immediately, stopped the transfer, and reconnected the hose properly. Only a very small amount of ammonia was lost.

Two very small leaks occurred in the small diameter piping/tubing associated with the metering and dilution system within the unused stack. These leaks were too small to be detected by area monitoring devices. Instead, they were found by operating personnel who detected slight odors of ammonia within the stack and in the vicinity of the metering system. The leak sites were located with portable detection devices and quickly repaired. 



\subsection{Quality Assurance/Quality Control}

A quality assurance/quality control program was conducted by SRI during the SCR demonstration project. A copy of the written Quality Assurance Program Plan (QAPP) was included as an appendix to the project's Environmental Monitoring Plan. The elements of this plan are briefly summarized below.

- Sampling Procedures. In general, applicable EPA reference methods were used to collect samples. These methods are described in detail in Title 40 Code of Federal Regulations, Part 60, Appendix A, and are summarized in Section 3 of this report. These established methods were used over the duration of the demonstration project.

- Analytical Procedures. Established EPA or ASTM reference methods, as listed in Section 3 of this report, were used to analyze all samples collected during the demonstration project. These methods establish the proper use of standards, blanks, matrix spikes, replicates, and calibration curves.

- Sample Custody. Procedures for tracking the handling and possession of each sample from collection through analysis and storage were followed as described in the QAPP. These procedures included guidelines for sample labeling, logging, record keeping, and review procedures.

- Calibration Procedures and Frequency. Flow measurement orifices, pitot tubes, manometers, and analytical balances were calibrated periodically during the demonstration program, using the procedures and frequencies described in the QAPP.

- Data reduction, Validation, and Reporting. Procedures were established and followed to protect the integrity of the reported results, as set out in the QAPP.

- Performance and Systems Audits. Periodic reviews of the total sampling and analytical system and of the capabilities of the measurement systems were conducted. Quarterly reports were submitted detailing the results of these audits.

A statistical analysis of the results for sample and analytical replicates was conducted, in which the relative standard deviation (RSD) was computed for the major parameters included in this report. The RSD is defined as the standard deviation divided by the mean value for a given parameter, and is a measure of data scatter. The results are summarized in Table 7-1. For most parameters, the average RSD was less than 10 percent. Higher RSDs were found for the concentrations of some species (e.g., $\mathrm{N}_{2} \mathrm{O}, \mathrm{SO}_{3}$, slip $\mathrm{NH}_{3}$, and reactor outlet $\mathrm{NO}_{\mathrm{x}}$ for test 
conditions leading to high control efficiencies). Since these species were present at low concentrations, relatively small differences in the absolute concentration led to large RSD values in some cases.

Table 8-1. Summary of Relative Standard Deviations for Replicates

\begin{tabular}{|c|c|c|}
\hline \multirow[b]{2}{*}{ Parameter } & \multicolumn{2}{|c|}{ Relative Standard Deviation ", \% } \\
\hline & Average RSD, \% & Range \\
\hline \multicolumn{3}{|l|}{ Particulate Matter Loading } \\
\hline Reactor Outlet & 3.5 & $0.0-15.0$ \\
\hline Air Preheaters & 8.9 & $4.6-15.9$ \\
\hline \multicolumn{3}{|c|}{$\begin{array}{l}\text { Ammonia Loss Tests (without catalyst) - Inlet \& } \\
\text { Outlet } \mathrm{NH}_{3} \text { Concentrations }\end{array}$} \\
\hline Reactor B & 9.8 & $5.5-18.0$ \\
\hline Reactor E & 6.4 & $2.6-13.5$ \\
\hline \multicolumn{3}{|l|}{$\mathrm{SO}_{2}$ Conversion Tests } \\
\hline $\mathrm{SO}_{2}$ Concentration & 2.7 & $0.3-10.1$ \\
\hline $\mathrm{SO}_{3}$ Concentration & 16.0 & $0.9-59.1$ \\
\hline \multicolumn{3}{|l|}{ Parametric Test Series 1-5 } \\
\hline Slip $\mathrm{NH}_{3}$ Concentration & 15.7 & $0.0-93.8$ \\
\hline $\mathrm{SO}_{3}$ Concentration & 20.5 & $1.3-119.8$ \\
\hline $\mathrm{SO}_{2}$ Concentration & 2.6 & $0.1-16.3$ \\
\hline HCL Concentration & 5.7 & $0.3-22.6$ \\
\hline $\mathrm{NO}_{\mathrm{x}}$ - Inlet Concentration & 2.4 & $0.0-53.5$ \\
\hline $\mathrm{NO}_{\mathrm{x}}$ - Outlet Concentration & 19.4 & $0.0-200.0$ \\
\hline $\mathrm{N}_{2} \mathrm{O}$ & $17^{b}$ & $10-30^{b}$ \\
\hline
\end{tabular}

${ }^{a}$ Relative Standard Deviation is defined as the standard deviation divided by the mean value.

${ }^{b}$ Estimated assuming precision of $0.3 \mathrm{ppm}$. 


\subsection{Compliance Reporting}

Discharge Monitoring Reports containing the monitoring results for the permitted ash pond discharge were submitted by Gulf Power Co. in Discharge Monitoring Reports as specified in the U.S. EPA NPDES Permit No. FL0002275 and in the State of Florida Department of Environmental Regulation Operating Permit No. IO17-109085. Monitored parameters included $\mathrm{pH}$, total suspended solids, and oil and grease. Copies of these reports have been included as appendices to the quarterly and annual EMP reports for the SCR demonstration project, and the results are summarized in Section 5. 



\subsection{Results and Conclusions}

The following is a summary of the EMP results obtained during the SCR Demonstration Project at Plant Crist:

- Apparent $\mathrm{NO}_{\mathrm{x}}$ reduction efficiencies measured during the parametric tests showed that all of the SCR catalysts were capable of reductions from 50 to $100 \%$, depending on reactor operating conditions. The mean reduction and observed range for each reactor based on parametric test data are summarized below:

\begin{tabular}{|c|c|c|c||}
\hline \multirow{2}{*}{ Reactor } & \multicolumn{2}{|c|}{ Apparent NO $_{\mathbf{x}}$ Reduction Efficiencies, \% } & NH $_{3}$ Slip, ppmv \\
\cline { 2 - 4 } & Mean & Range & Range \\
\hline \hline A & 79.9 & $61.8-94.1$ & $0.8-29$ \\
\hline B & 84.5 & $66.9-99.8$ & $<0.7-35.3$ \\
\hline C & 88.9 & $69.5-99.2$ & $0.8-58$ \\
\hline D & 89.1 & $80.9-96.7$ & $<1.3-94.1$ \\
\hline E & 81.7 & $62.0-93.9$ & $<0.1-68$ \\
\hline F & 84.7 & $70.6-96.0$ & $<0.8-90.1$ \\
\hline G & 78.2 & $64.3-88.8$ & $<0.7-94.1$ \\
\hline J & 68.7 & $51.2-85.7$ & $<0.8-24.4$ \\
\hline
\end{tabular}

These reduction efficiencies should not be construed as necessarily reflecting the relative performance of the different catalysts in the reactors. Many factors impact the $\mathrm{NO}_{\mathrm{x}}$ reduction efficiencies, and all of the reactors may not have experienced the same sequence of test parameters. In many cases, very high reductions efficiencies were achieved at conditions that may not be practical in routine operation. For example, at very high $\mathrm{NO}_{\mathrm{x}}$ reduction efficiencies, ammonia slip could be as high as $90 \mathrm{ppmv}$. The ranges of ammonia slip measured during the parametric test sequences are also included in the table.

In general, changes to the major SCR reactor operating parameters had the following impacts:

- Increasing the ammonia-to-nitrogen oxide ratio resulted in increased $\mathrm{NO}_{\mathrm{x}}$ reduction efficiency and increased ammonia slip.

- Increasing reactor residence time (i.e., reducing the flue gas flow rate) resulted in increased $\mathrm{NO}_{x}$ reduction efficiency and reduced ammonia slip. 
- Increasing reactor temperature did not have a definitive impact on $\mathrm{NO}_{x}$ reduction efficiency, but ammonia slip was reduced.

- The $\mathrm{SO}_{3}$ concentration in the flue gas generally increased slightly across the SCR reactors, due to conversion of a portion of the $\mathrm{SO}_{2}$. The fraction of $\mathrm{SO}_{2}$ converted tended to increase with increasing reactor temperature and residence time. In many cases there was a slight decrease in $\mathrm{SO}_{2}$ conversion as catalyst exposure time increased.

- $\mathrm{N}_{2} \mathrm{O}$ concentrations upstream and downstream of the SCR reactors were all low, with the observed range varying from 1 to about $3 \mathrm{ppmv}$. No consistent trend toward increasing or decreasing concentration across the SCR reactors was observed; in many cases, there was no significant change in $\mathrm{N}_{2} \mathrm{O}$ concentration between the SCR reactor inlet and outlet.

- An apparent increase in $\mathrm{HCl}$ concentration across the SCR reactors appeared to be an artifact of the sampling methods used for the SCR reactor inlet and outlet streams.

- The particulate matter loading was apparently higher at the SCR reactor outlets than at the ESP inlet upstream of the reactors. However, the ESP inlet loading measurements appeared to be low, based on subsequent measurements made in the economizer bypass duct at low boiler load conditions. As expected, the average loading was higher at high load than at low load (i.e., 3.9 and $3.5 \mathrm{gr} / \mathrm{dscf}$ @, 3\% $\mathrm{O}_{2}$, respectively).

- Good agreement was observed in both particulate matter size distribution and composition at the main reactor inlet and downstream of the last catalyst level for each of the SCR reactors.

- Based on the results of the TCLP analyses of the fly ash samples obtained at the SCR reactor inlet, outlet, or air preheater outlet, no significant change was noted across the SCR reactors, and none of these solids would be classified as hazardous under Title III of RCRA, with respect to the toxic metals.

- As expected, the SCR demonstration project did not have any detectable impact on the measured water quality parameters for the ash pond discharge stream.

- The ammonia storage and delivery system design was effective in minimizing the inadvertent release of ammonia. 


\subsection{References}

1. Radian Corporation, Environmental Monitoring Plan (EMP) Southern Company Services Selective Catalytic Reduction Project at Plant Crist, Pensacola, Florida, Revised March 1993.

2. Southern Company Services, Inc., Innovative Clean Coal Technology (ICCT) Demonstration of Selective Catalytic Reduction (SCR) Technology for the Control of Nitrogen Oxide $\left(N O_{x}\right)$ Emissions from High-Sulfur Coal-Fired Boilers, Volumes 1-3. Final Report. October 1996.

3. Southern Research Institute, Testing and Analytical Services for the Innovative Clean Coal Technology Demonstration of Selective Catalytic Reduction (SCR) Technology for the Control of Nitrogen Oxide (NO ) Emissions from High Sulfur Coal, Final Report for Task 1: Commissioning without Catalysts and without Ammonia Injection. Draft Report, September 30, 1993.

4. Southern Research Institute, Testing and Analytical Services for the Innovative Clean Coal Technology Demonstration of Selective Catalytic Reduction (SCR) Technology for the Control of Nitrogen Oxide (NO ) Emissions from High Sulfur Coal, Final Report for Task 2: Commissioning without Catalysts and with Ammonia Injection. Draft Report, December 15, 1993.

5. Southern Research Institute, Testing and Analytical Services for the Innovative Clean Coal Technology Demonstration of Selective Catalytic Reduction (SCR) Technology for the Control of Nitrogen Oxide (NO) Emissions from High Sulfur Coal, Task $3 A$ :

Commissioning with Catalyst and without Ammonia Injection and Task 3B: Preliminary Parametric Test, Parts I-6, Final Report, October 6, 1995.

6. Southern Research Institute, Testing and Analytical Services for the Innovative Clean Coal Technology Demonstration of Selective Catalytic Reduction (SCR) Technology for the Control of Nitrogen Oxide (NO) Emissions from High Sulfur Coal, Interim Report for Task 4: Long-Term Parametric Tests, 2nd Sequence, Parts 1-7. Draft Report, August $31,1994$.

7. Southern Research Institute, Testing and Analytical Services for the Innovative Clean Coal Technology Demonstration of Selective Catalytic Reduction (SCR) Technology for the Control of Nitrogen Oxide $\left(N O_{x}\right)$ Emissions from High Sulfur Coal, Task 4: Third Long-Term Parametric Test, Parts 1-8. Final Report, November 22, 1995. 
8. Southern Research Institute, Testing and Analytical Services for the Innovative Clean Coal Technology Demonstration of Selective Catalytic Reduction (SCR) Technology for the Control of Nitrogen Oxide $\left(N O_{x}\right)$ Emissions from High Sulfur Coal, Interim Report for Task 4: Long-Term Parametric Tests, 4th Sequence, Parts 1-8. Draft Report, April 15, 1995.

9. Southern Research Institute, Testing and Analytical Services for the Innovative Clean Coal Technology Demonstration of Selective Catalytic Reduction (SCR) Technology for the Control of Nitrogen Oxide (NO) Emissions from High Sulfur Coal, Task 4: Fifth Long-Term Parametric Test, Parts 1-8. Final Report, January 31, 1996.

10. Southern Research Institute, Testing and Analytical Services for the Innovative Clean Coal Technology Demonstration of Selective Catalytic Reduction (SCR) Technology for the Control of Nitrogen Oxide $\left(N O_{x}\right)$ Emissions from High Sulfur Coal, Effects of SCR Ammonia on Ammonia Volatilization, Ammonia Extraction, and Metals Extraction from SCR Fly Ash. Final Report, October 25, 1995. 


\section{Appendix A \\ Monitoring Data Summary Tables}




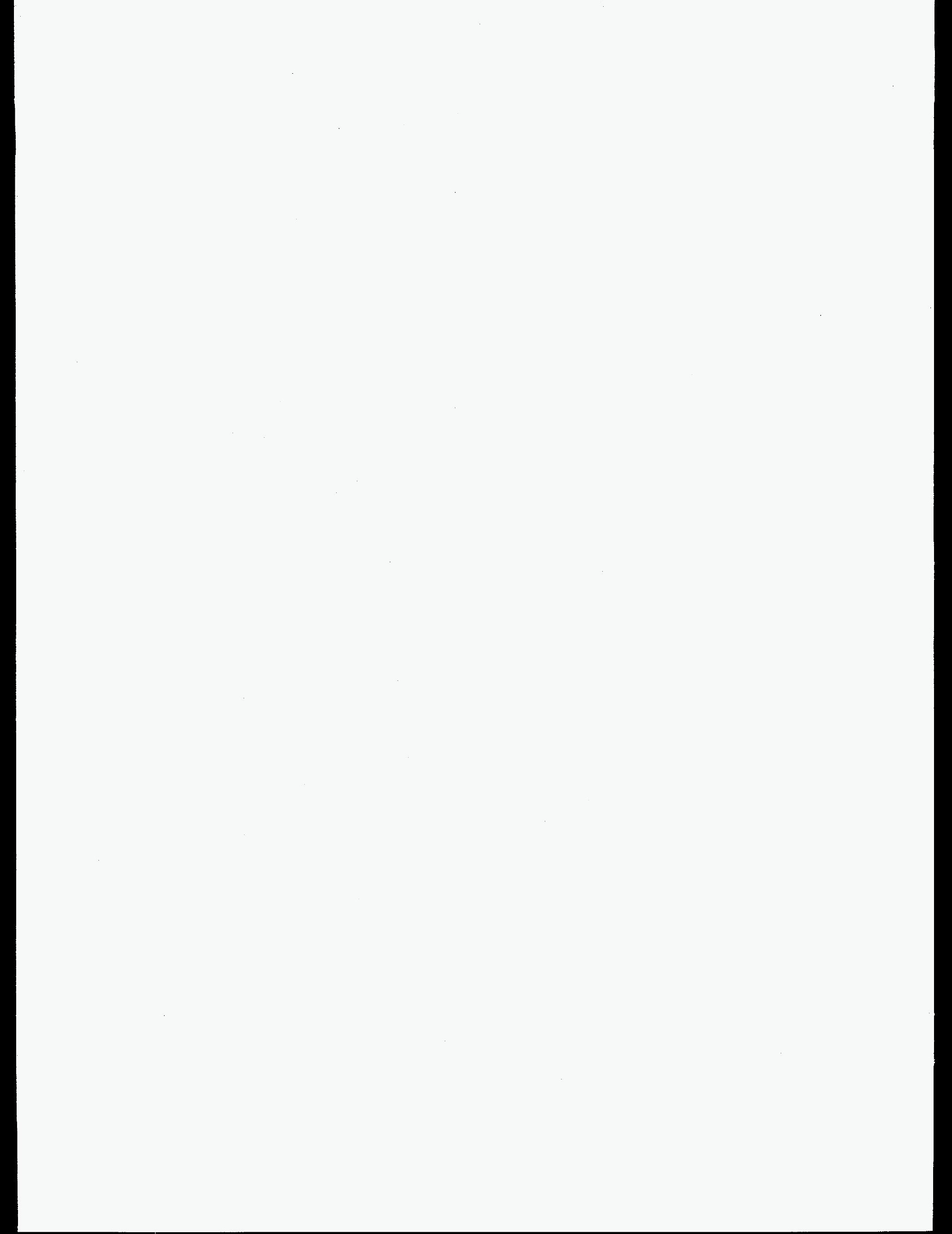




\section{List of Tables}

A-1 SCR Reactor Outlet Particulate Matter Loading Data $\ldots \ldots \ldots \ldots \ldots \ldots \ldots$

A-2 Particulate Matter Loading Data-Air Preheaters $\ldots \ldots \ldots \ldots \ldots \ldots \ldots \ldots \ldots$

A-3 Ash Minerals Analysis Summary $\ldots \ldots \ldots \ldots \ldots \ldots \ldots \ldots \ldots \ldots \ldots$

A-4 Trace Metals Concentrations in Ash Samples . . . . . . . . . . . . . . . A-10

A-5 Ammonia Concentration Across Reactors Without Catalyst . . . . . . . . A-11

A-6 $\mathrm{SO}_{2}$ Oxidation Test Data $\ldots \ldots \ldots \ldots \ldots \ldots \ldots \ldots \ldots \ldots \ldots \ldots \ldots \ldots \ldots$

A-7 Parametric Test Data_Test Sequence $1 \ldots \ldots \ldots \ldots \ldots \ldots \ldots \ldots \ldots \ldots$

A-8 Parametric Test Data-Test Sequence $2 \ldots \ldots \ldots \ldots \ldots \ldots \ldots \ldots \ldots$

A-9 Parametric Test Data-Test Sequence $3 \ldots \ldots \ldots \ldots \ldots \ldots \ldots \ldots \ldots$ A $\ldots \ldots \ldots$

A-10 Parametric Test Data-Test Sequence $4 \ldots \ldots \ldots \ldots \ldots \ldots \ldots \ldots \ldots \ldots$

A-11 Parametric Test Data-Test Sequence $5 \ldots \ldots \ldots \ldots \ldots \ldots \ldots \ldots \ldots \ldots$

A-12 Monthly Average Coal Analyses $\ldots \ldots \ldots \ldots \ldots \ldots \ldots \ldots \ldots \ldots \ldots \ldots \ldots$ 

Table A-1. SCR Reactor Outlet Particulate Matter Loading Data

\begin{tabular}{|c|c|c|c|c|c|}
\hline $\begin{array}{l}\text { Test No./ } \\
\text { Sequence }\end{array}$ & Reactor & Date & Load, MW & Oxygen, vol\% & PM, gr/dscf \\
\hline \multirow[t]{32}{*}{1} & \multirow[t]{4}{*}{$\mathrm{A}$} & 1 June 1993 & 84 & 3.0 & 4.01 \\
\hline & & 2 June 1993 & 84 & 3.1 & 3.81 \\
\hline & & 3 June 1993 & 43 & 7.9 & 3.59 \\
\hline & & 3 June 1993 & 43 & 7.8 & 3.60 \\
\hline & \multirow[t]{4}{*}{ B } & 1 June 1993 & 84 & 2.5 & 4.21 \\
\hline & & 1 June 1993 & 84 & 3.1 & 4.05 \\
\hline & & 3 June 1993 & 43 & 7.5 & 3.41 \\
\hline & & 3 June 1993 & 43 & 7.7 & 3.41 \\
\hline & \multirow[t]{4}{*}{$\mathrm{C}$} & 7 June 1993 & 84 & 2.4 & 3.77 \\
\hline & & 7 June 1993 & 84 & 2.5 & 3.91 \\
\hline & & 3 June 1993 & 43 & 7.6 & 3.53 \\
\hline & & 3 June 1993 & 43 & 7.4 & 3.49 \\
\hline & \multirow[t]{4}{*}{$\mathrm{D}$} & 14 May 1993 & 84 & 5.7 & 3.18 \\
\hline & & 14 May 1993 & 84 & 5.2 & 3.08 \\
\hline & & 4 June 1993 & 43 & 9.3 & 3.52 \\
\hline & & 4 June 1993 & 43 & 9.2 & 3.39 \\
\hline & \multirow[t]{4}{*}{$\mathrm{E}$} & 27 May 1993 & 84 & 3.3 & 4.31 \\
\hline & & 2 June 1993 & 84 & 4.8 & 4.08 \\
\hline & & 4 June 1993 & 43 & 8.6 & 3.85 \\
\hline & & 4 June 1993 & 43 & 8.4 & 3.90 \\
\hline & \multirow[t]{4}{*}{$\mathrm{F}$} & 27 May 1993 & 84 & 5.0 & 4.84 \\
\hline & & 2 June 1993 & 84 & 3.9 & 3.91 \\
\hline & & 4 June 1993 & 43 & 8.7 & 3.67 \\
\hline & & 4 June 1993 & 43 & 8.9 & 3.81 \\
\hline & \multirow[t]{4}{*}{ G } & 27 May 1993 & 84 & 4.6 & 3.94 \\
\hline & & 27 May 1993 & 84 & 3.9 & 3.81 \\
\hline & & 3 June 1993 & 43 & 8.6 & 3.30 \\
\hline & & 3 June 1993 & 43 & 8.6 & 3.28 \\
\hline & \multirow[t]{4}{*}{$\mathrm{H}$} & 27 May 1993 & 84 & 4.2 & 3.96 \\
\hline & & 27 May 1993 & 84 & 4.0 & 3.54 \\
\hline & & 4 June 1993 & 43 & 8.7 & 3.48 \\
\hline & & 4 June 1993 & 43 & 8.1 & 3.09 \\
\hline \multirow[t]{6}{*}{$4-1$} & \multirow[t]{6}{*}{ A } & 21 September 1993 & 90 & 1.5 & 3.97 \\
\hline & & 21 September 1993 & 90 & 1.5 & 3.94 \\
\hline & & 22 September 1993 & 90 & 1.6 & 5.66 \\
\hline & & 22 September 1993 & 90 & 1.6 & 6.82 \\
\hline & & 22 September 1993 & 90 & 1.6 & 4.55 \\
\hline & & 21 September 1993 & 90 & 1.5 & 4.17 \\
\hline
\end{tabular}


Table A-1 (continued)

\begin{tabular}{|c|c|c|c|c|c|}
\hline $\begin{array}{l}\text { Test No./ } \\
\text { Sequence }\end{array}$ & Reactor & Date & Load, MW & Oxygen, vol $\%$ & PM, gr/dscf \\
\hline \multirow{27}{*}{$\begin{array}{c}4-1 \\
\text { Cont'd }\end{array}$} & \multirow[t]{12}{*}{ B } & 14 July 1993 & 64 & 6.1 & 3.53 \\
\hline & & 14 July 1993 & 64 & 6.1 & 3.53 \\
\hline & & 14 July 1993 & 64 & 6.1 & 3.50 \\
\hline & & 14 July 1993 & 64 & 6.1 & 3.05 \\
\hline & & 14 July 1993 & 64 & 6.1 & 3.40 \\
\hline & & 14 July 1993 & 64 & 6.1 & 3.36 \\
\hline & & 15 July 1993 & 84 & 6.1 & 5.22 \\
\hline & & 15 July 1993 & 84 & 6.1 & 5.14 \\
\hline & & 15 July 1993 & 84 & 6.1 & 4.50 \\
\hline & & 15 July 1993 & 84 & 6.1 & 4.82 \\
\hline & & 15 July 1993 & 84 & 6.1 & 5.02 \\
\hline & & 15 July 1993 & 84 & 6.1 & 5.26 \\
\hline & \multirow[t]{6}{*}{$\mathrm{C}$} & 16 July 1993 & 84 & 3.5 & 5.13 \\
\hline & & 16 July 1993 & 84 & 3.5 & 4.51 \\
\hline & & 16 July 1993 & 84 & 3.5 & 4.93 \\
\hline & & 16 July 1993 & 84 & 3.5 & 4.88 \\
\hline & & 16 July 1993 & 84 & 3.5 & 4.48 \\
\hline & & 16 July 1993 & 84 & 3.5 & 4.67 \\
\hline & \multirow[t]{3}{*}{$\mathrm{D}$} & 28 October 1993 & 84 & 3.5 & 3.12 \\
\hline & & 29 October 1993 & 84 & 3.5 & 2.87 \\
\hline & & 29 October 1993 & 84 & 3.5 & 2.67 \\
\hline & \multirow[t]{3}{*}{$\mathrm{E}$} & 28 October 1993 & 84 & 3.5 & 3.30 \\
\hline & & 29 October 1993 & 84 & 3.5 & 2.96 \\
\hline & & 29 October 1993 & 84 & 3.5 & 3.92 \\
\hline & \multirow[t]{3}{*}{$\mathrm{F}$} & 28 October 1993 & 84 & 3.5 & 3.69 \\
\hline & & 29 October 1993 & 84 & 3.5 & 3.78 \\
\hline & & 29 October 1993 & 84 & 3.5 & 4.55 \\
\hline \multirow[t]{13}{*}{$4-2$} & \multirow[t]{5}{*}{ A } & 4 February 1994 & 84 & 2.8 & 3.87 \\
\hline & & 4 February 1994 & 84 & 2.8 & 3.44 \\
\hline & & 4 February 1994 & 84 & 2.8 & 3.19 \\
\hline & & 4 February 1994 & 84 & 2.8 & 3.44 \\
\hline & & 4 February 1994 & 84 & 2.8 & 3.48 \\
\hline & \multirow[t]{5}{*}{ B } & 7 February 1994 & 84 & 2.7 & 3.78 \\
\hline & & 7 February 1994 & 84 & 2.7 & 2.71 \\
\hline & & 7 February 1994 & 84 & 2.7 & 3.06 \\
\hline & & 7 February 1994 & 84 & 2.7 & 2.78 \\
\hline & & 7 February 1994 & 84 & 2.7 & 3.76 \\
\hline & \multirow[t]{3}{*}{$\mathrm{C}$} & 9 February 1994 & 84 & 3.1 & 3.75 \\
\hline & & 9 February 1994 & 84 & 3.1 & 3.31 \\
\hline & & 9 February 1994 & 84 & 3.1 & 3.05 \\
\hline
\end{tabular}


Table A-1 (continued)

\begin{tabular}{|c|c|c|c|c|c|}
\hline $\begin{array}{l}\text { Test No./ } \\
\text { Sequence }\end{array}$ & Reactor & Date & Load, MW & Oxygen, vol\% & PM, gr/dscf \\
\hline \multirow{8}{*}{$\begin{array}{c}\text { 4-2 } \\
\text { Cont'd }\end{array}$} & \multirow[t]{2}{*}{$\mathrm{C}$} & 9 February 1994 & 84 & 3.1 & 3.21 \\
\hline & & 9 February 1994 & 84 & 3.1 & 3.04 \\
\hline & \multirow[t]{2}{*}{ D } & 10 February 1994 & 84 & 5.4 & 4.13 \\
\hline & & 10 February 1994 & 84 & 5.4 & 3.31 \\
\hline & \multirow[t]{2}{*}{$\mathrm{E}$} & 21 February 1994 & 84 & 4.8 & 4.66 \\
\hline & & 21 February 1994 & 84 & 4.8 & 5.85 \\
\hline & \multirow[t]{2}{*}{$\mathbf{F}$} & 21 February 1994 & 84 & 4.4 & 8.61 \\
\hline & & 21 February 1994 & 84 & 4.4 & 7.13 \\
\hline \multirow[t]{23}{*}{$4-4$} & \multirow[t]{5}{*}{ A } & 6 December 1994 & 84 & 3.30 & 4.05 \\
\hline & & 6 December 1994 & 84 & 3.78 & 3.68 \\
\hline & & 6 December 1994 & 84 & 3 & 3.64 \\
\hline & & 6 December 1994 & 84 & 3.1 & 4.35 \\
\hline & & 6 December 1994 & 84 & 3.6 & 3.62 \\
\hline & \multirow[t]{5}{*}{ B } & 10 November 1994 & 84 & 3 & 3.33 \\
\hline & & 10 November 1994 & 84 & 2.9 & 3.01 \\
\hline & & 10 November 1994 & 84 & 2.5 & 3.27 \\
\hline & & 10 November 1994 & 84 & 3.4 & 3.34 \\
\hline & & 10 November 1994 & 84 & 4.3 & 3.41 \\
\hline & \multirow[t]{5}{*}{$\mathrm{C}$} & 11 November 1994 & 84 & 2.86 & 3.64 \\
\hline & & 11 November 1994 & 84 & 2.80 & 3.66 \\
\hline & & 11 November 1994 & 84 & 2.90 & 3.42 \\
\hline & & 11 November 1994 & 84 & 4.8 & 3.28 \\
\hline & & 11 November 1994 & 84 & 3.6 & 3.08 \\
\hline & \multirow[t]{2}{*}{$\mathrm{D}$} & 7 December 1994 & 84 & 4.3 & 4.52 \\
\hline & & 7 December 1994 & 84 & 4.5 & 3.95 \\
\hline & \multirow[t]{2}{*}{$\mathrm{E}$} & 7 December 1994 & 84 & 3.6 & 4.08 \\
\hline & & 7 December 1994 & 84 & 3.4 & 4.42 \\
\hline & \multirow[t]{2}{*}{ F } & 5 December 1994 & 84 & 3.5 & 4.23 \\
\hline & & 5 December 1994 & 84 & 3.1 & 4.46 \\
\hline & \multirow[t]{2}{*}{$\mathrm{G}$} & 5 December 1994 & 84 & 3.3 & 3.06 \\
\hline & & 5 December 1994 & 84 & 3.1 & 3.56 \\
\hline
\end{tabular}


Table A-2. Particulate Matter Loading Data-Air Preheaters

\begin{tabular}{|c|c|c|c|}
\hline Reactor No. & Test Location & Date & PM (ar/dsef) \\
\hline \multirow[t]{15}{*}{$\mathrm{A}$} & \multirow[t]{6}{*}{ Air Preheater Inlet } & 25 Apr 1994 & 3.9 \\
\hline & & 25 Apr 1994 & 3.6 \\
\hline & & 25 Apr 1994 & 3.0 \\
\hline & & 8 Nov 1994 & 2.6 \\
\hline & & 8 Nov 1994 & 3.4 \\
\hline & & 8 Nov 1994 & 3.5 \\
\hline & \multirow[t]{9}{*}{ Air Preheater Outlet } & 25 Apr 1994 & 3.5 \\
\hline & & 25 Apr 1994 & 3.3 \\
\hline & & 25 Apr 1994 & 2.8 \\
\hline & & 9 Jun 1994 & 2.6 \\
\hline & & 9 Jun 1994 & 2.4 \\
\hline & & 9 Jun 1994 & 2.5 \\
\hline & & 8 Nov 1994 & 2.7 \\
\hline & & 8 Nov 1994 & 2.7 \\
\hline & & 8 Nov 1994 & 2.6 \\
\hline \multirow[t]{14}{*}{ B } & \multirow[t]{6}{*}{ Air Preheater Inlet } & 2 May 1994 & 3.4 \\
\hline & & 2 May 1994 & 3.3 \\
\hline & & 2 May 1994 & 3.5 \\
\hline & & 9 Nov 1994 & 3.9 \\
\hline & & 9 Nov 1994 & 3.5 \\
\hline & & 9 Nov 1994 & 3.4 \\
\hline & \multirow[t]{8}{*}{ Air Preheater Outlet } & 2 May 1994 & 2.7 \\
\hline & & 2 May 1994 & 2.7 \\
\hline & & 2 May 1994 & 2.9 \\
\hline & & 10 Jun 1994 & 2.4 \\
\hline & & 10 Jun 1994 & 2.3 \\
\hline & & 10 Jun 1994 & 2.3 \\
\hline & & 9 Nov 1994 & 2.5 \\
\hline & & 9 Nov 1994 & 2.4 \\
\hline \multirow[t]{3}{*}{$\mathrm{C}$} & \multirow[t]{3}{*}{ Air Preheater Inlet } & 26 Apr 1994 & 3.6 \\
\hline & & 26 Apr 1994 & 3.9 \\
\hline & & 26 Apr 1994 & 4.0 \\
\hline
\end{tabular}


Table A-3. Ash Minerals Analysis Summary

\begin{tabular}{|c|c|c|c|c|c|c|c|c|c|c|}
\hline \multirow[b]{2}{*}{ Snecies } & \multicolumn{2}{|c|}{ As-Fired Coal } & \multicolumn{3}{|c|}{ ESP Inlet } & \multicolumn{4}{|c|}{ Reactor A Outlet } & \multirow{2}{*}{$\begin{array}{r}\text { React } \\
2 \text { May } 1996\end{array}$} \\
\hline & $10 \mathrm{Feb} 1993$ & 11Feb 1993 & 9 Feb 1993 & & Feb 1993 & \multicolumn{2}{|c|}{25 Apr 1994} & \multicolumn{2}{|c|}{8 Noy 1994} & \\
\hline $\mathrm{SiO}_{2}$ & 44.3 & 47.4 & 48.9 & & 48.4 & \multicolumn{2}{|c|}{48.0} & \multicolumn{2}{|c|}{47.59} & 49.3 \\
\hline $\mathrm{Al}_{2} \mathrm{O}_{3}$ & 22.6 & 22.5 & 22.7 & & 22.7 & \multicolumn{2}{|r|}{22.2} & \multicolumn{2}{|c|}{23.73} & 22.3 \\
\hline $\mathrm{TiO}_{2}$ & 0.83 & 0.83 & 1 & & 1 & \multicolumn{2}{|r|}{1.1} & \multicolumn{2}{|c|}{1.15} & 1.1 \\
\hline $\mathrm{Fe}_{2} \mathrm{O}_{3}$ & 19.9 & 20.6 & 17.8 & & 18.1 & \multicolumn{2}{|r|}{18.7} & \multicolumn{2}{|c|}{16.81} & 18.5 \\
\hline $\mathrm{CaO}$ & 4.6 & 2.8 & 4.6 & & 4 & \multicolumn{2}{|r|}{3.5} & \multicolumn{2}{|c|}{2.93} & 2.9 \\
\hline $\mathrm{MgO}$ & 0.91 & 0.78 & 0.97 & & 0.97 & \multicolumn{2}{|r|}{0.98} & \multicolumn{2}{|c|}{0.91} & 1 \\
\hline $\mathrm{K}_{2} \mathrm{O}$ & 2.3 & 2 & 2.8 & & 2.5 & \multicolumn{2}{|r|}{2.4} & \multicolumn{2}{|c|}{2.76} & 2.4 \\
\hline $\mathrm{Na}_{2} \mathrm{O}$ & 0.8 & 0.66 & 0.79 & & 0.87 & \multicolumn{2}{|r|}{0.97} & \multicolumn{2}{|c|}{0.94} & 1.2 \\
\hline $\mathrm{SO}_{3}$ & 4 & 2.5 & 0.99 & & 1.2 & \multicolumn{2}{|r|}{1.1} & \multicolumn{2}{|c|}{0.79} & 0.78 \\
\hline $\mathrm{P}_{2} \mathrm{O}_{5}$ & 0.18 & 0.16 & 0.18 & & 0.16 & \multicolumn{2}{|r|}{0.14} & \multicolumn{2}{|c|}{0.49} & 0.14 \\
\hline $\mathrm{Li}_{2} \mathrm{O}$ & 0.02 & 0.02 & 0.02 & & 0.02 & & 0.03 & & & 0.03 \\
\hline SrO & NA & NA & NA & & NA & & NA & & & NA \\
\hline $\mathrm{BaO}$ & NA & NA & NA & & NA & & $\mathrm{NA}$ & & & NA \\
\hline $\mathrm{MnO}$ & $\mathrm{NA}$ & NA & NA & & NA & & NA & & & NA \\
\hline Undetermined & $\mathrm{NA}$ & $\mathrm{NA}$ & $\mathrm{NA}$ & & 0.08 & & 0.88 & & & 0.35 \\
\hline & & APH $^{0}$ & A Outlet & & & $\overline{\mathbf{A P H}}$ & B Outlet & & & HC Inlet \\
\hline & Species & 25 Apr 1994 & 8 Nov 15 & & $2 \mathrm{Ma}$ & 1994 & $=9 \mathrm{Nr}$ & 1994 & & Apr 1994 \\
\hline & $\mathrm{SiO}_{2}$ & 47.4 & 48.58 & & 49 & & & 36 & & 49.0 \\
\hline & $\mathrm{Al}_{2} \mathrm{O}_{3}$ & 22.0 & 24.03 & & 21 & & & .04 & & 21.9 \\
\hline & $\mathrm{TiO}_{2}$ & 1.1 & 1.15 & & 0 . & & & 24 & & 0.91 \\
\hline & $\mathrm{Fe}_{2} \mathrm{O}_{3}$ & 20.3 & 16.61 & & 18 & & & 18 & & 18.5 \\
\hline & $\mathrm{CaO}$ & 3.7 & 2.98 & & 2 & & & 51 & & 3.3 \\
\hline & $\mathrm{MgO}$ & 0.97 & 0.93 & & 0. & & & 93 & & 1.0 \\
\hline & $\mathrm{K}_{2} \mathrm{O}$ & 2.2 & 2.81 & & 2 & & & 96 & & 2.5 \\
\hline & $\mathrm{Na}_{2} \mathrm{O}$ & 0.91 & 0.96 & & 1 & & & 04 & & 0.91 \\
\hline & $\mathrm{SO}_{3}$ & 1.0 & 0.88 & & 0. & & & 95 & & 0.78 \\
\hline & $\mathrm{P}_{2} \mathrm{O}_{5}$ & 0.14 & 0.49 & & 0. & & & & & 0.14 \\
\hline & $\mathrm{Li}_{2} \mathrm{O}$ & 0.03 & NA & & 0. & & & $A$ & & 0.04 \\
\hline & SrO & NA & 0.08 & & $\mathrm{~N}$ & & & 1 & & NA \\
\hline & $\mathrm{BaO}$ & NA & 0.07 & & $\mathrm{~N}$ & & & 07 & & NA \\
\hline & $\mathrm{MnO}$ & NA & 0.09 & & $\mathrm{~N}$ & & & .1 & & NA \\
\hline & Undetermine & 0.25 & 0.34 & & 1 & & & 293 & & 1.02 \\
\hline
\end{tabular}

a Units: \% by weight.

${ }^{b} \mathrm{APH}=$ Air preheater. 
Table A-4. Trace Metals Concentrations in Ash Samples ${ }^{a}$

\begin{tabular}{|c|c|c|c|c|c|c|c|c|c|c|}
\hline \multirow[b]{3}{*}{ Element } & \multirow{2}{*}{\multicolumn{2}{|c|}{ ESP Inlet }} & \multirow{2}{*}{\multicolumn{2}{|c|}{ ESP Outlet }} & \multirow{2}{*}{\multicolumn{2}{|c|}{ Reactor A Inlet }} & \multicolumn{2}{|c|}{ Air Preheater A } & \multicolumn{2}{|c|}{ Air Preheater B } \\
\hline & & & & & & & \multirow{2}{*}{$\frac{\text { Inlet }}{8 \text { Nov } 1994}$} & \multirow{2}{*}{$\frac{\text { Outlet }}{8 \text { Nov } 1994}$} & \multirow{2}{*}{$\frac{\text { Inlet }}{9 \text { Nov } 1994}$} & \multirow{2}{*}{$\frac{\text { Outlet }}{9 \text { Nov } 1994}$} \\
\hline & $\begin{array}{l}9 \text { Feb } 1993 \\
\text { High Load } \\
\end{array}$ & $\begin{array}{c}11 \text { Feb } 1993 \\
\text { Low Load } \\
\end{array}$ & $\begin{array}{l}9 \text { Feb } 1993 \\
\text { High Load } \\
\end{array}$ & $\begin{array}{c}11 \text { Feb } 1993 \\
\text { Low Load } \\
\end{array}$ & $\begin{array}{l}6 \text { Mar } 1993 \\
\text { High Load } \\
\end{array}$ & $\begin{array}{r}6 \text { Mar } 1993 \\
\text { Low Load } \\
\end{array}$ & & & & \\
\hline Antimony & 9 & 2.9 & $<180.0$ & $<3.6$ & 6.1 & 8.3 & 15 & 12 & 12 & 17.3 \\
\hline Arsenic & 139 & 69.7 & 110 & 97.9 & 51.3 & 47.2 & 145 & 146 & 146 & 171 \\
\hline Barium & 298 & 377 & 339 & 563 & 302 & 259 & 305 & 357 & 455 & 431 \\
\hline Beryllium & 11.3 & 14.5 & $<35.0$ & 21 & 9.6 & 10.3 & 17.6 & 17.3 & 17.7 & 18.2 \\
\hline Cadmium & 5.9 & 10.3 & 39.1 & 20 & 4.6 & 7.2 & 4.3 & $<4.0$ & $<4.0$ & $\leq 4.0$ \\
\hline Cesium & 85.5 & 74.6 & $<3500$ & $<80.0$ & 72.9 & 69.9 & $<33$ & $<32$ & $<32$ & $<31$ \\
\hline Chromium & 124 & 148 & 241 & 152 & 132 & 124 & 148 & 151 & 151 & 168 \\
\hline Cobalt & 23 & 30.6 & $<70.0$ & 30.7 & 27.4 & 22.8 & 50.6 & 50.1 & 53.8 & 54.1 \\
\hline Copper & 71.6 & 86.4 & 215 & 93.2 & 66.2 & 65.4 & 125 & 125 & 144 & 148 \\
\hline Lead & 221 & 286 & 426 & 404 & 227 & 239 & 298 & 227 & 277 & 319 \\
\hline Manganese & 152 & 172 & 226 & 174 & 225 & 169 & 173 & 168 & 158 & 160 \\
\hline Mercury & 0.35 & 0.13 & $<7.0$ & 0.21 & 0.12 & 0.18 & 0.019 & 0.63 & $<0.010$ & 1.29 \\
\hline Molybdenum & 72.9 & 77 & 880 & 85.7 & 82.6 & 74.6 & 26.3 & 25.2 & 25.3 & 27.8 \\
\hline Nickel & 86.5 & 104 & $<180$ & 106 & 100 & 89.5 & 156 & 157 & 167 & 179 \\
\hline Rubidium & 134 & 126 & $<1800$ & 125 & 132 & 123 & 93.2 & 117 & 155 & 142 \\
\hline Selenium & 99.3 & 8.02 & 514 & 13.7 & 1.37 & 7.1 & $<0.56$ & 3.7 & $<0.54$ & 6.7 \\
\hline Strontium & 186 & 237 & 228 & 252 & 188 & 175 & 472 & 546 & 766 & 736 \\
\hline rin & 26.8 & 31.1 & $<180$ & 22.7 & 21.5 & 20 & 78.2 & 83.9 & 93.1 & 75.8 \\
\hline Vanadium & 683 & 458 & 577 & 428 & 467 & 531 & 348 & 348 & 368 & 380 \\
\hline Zinc & 311 & 647 & 3320 & 1118 & 436 & 353 & 247 & 252 & 227 & 241 \\
\hline
\end{tabular}

a Units: $\mu \mathrm{g} / \mathrm{g}$ (ppmw). 
Table A-5. Ammonia Concentration Across Reactors Without Catalyst

\begin{tabular}{|c|c|c|c|c|c|c|}
\hline Reartor & Pasition & Date & $\begin{array}{c}\text { Temperature, } \\
{ }^{\circ} \mathrm{F}\end{array}$ & $\begin{array}{c}\text { Flow Rate, } \\
\text { kwscfim }\end{array}$ & $\begin{array}{c}\mathrm{O}_{2}, \\
\text { Volume\% } \\
\end{array}$ & $\begin{array}{c}\mathrm{NH}_{3} \text {, wppmv } \\
\text { a } 3 \% \text {. }\end{array}$ \\
\hline \multirow[t]{20}{*}{ B } & Inlet & 9 June 1993 & 750 & 7.5 & 2.52 & 228.1 \\
\hline & Inlet & 9 June 1993 & 750 & 7.5 & 2.55 & 180.7 \\
\hline & Outlet & 9 June 1993 & 750 & 7.5 & 2.61 & 184.8 \\
\hline & Outlet & 9 June 1993 & 750 & 7.5 & 2.86 & 218.3 \\
\hline & Outlet & 9 June 1993 & 750 & 7.5 & 2.86 & 203.4 \\
\hline & Inlet & 9 June 1993 & 750 & 3.0 & 2.55 & 191.6 \\
\hline & Inlet & 9 June 1993 & 750 & 3.0 & 2.54 & 213.7 \\
\hline & Inlet & 9 June 1993 & 750 & 3.0 & 2.48 & 193.8 \\
\hline & Outlet & 9 June 1993 & 750 & 3.0 & 2.84 & 179 \\
\hline & Outlet & 9 June 1993 & 750 & 3.0 & 3.15 & 166.8 \\
\hline & Outlet & 9 June 1993 & 750 & 3.0 & 2.77 & 205.4 \\
\hline & Inlet & 10 June 1993 & 620 & 7.5 & 2.8 & 202.7 \\
\hline & Inlet & 10 June 1993 & 620 & 7.5 & 2.9 & 227.3 \\
\hline & Inlet & 10 June 1993 & 620 & 7.5 & 2.97 & 157.6 \\
\hline & Outlet & 10 June 1993 & 620 & 7.5 & 3.3 & 209.9 \\
\hline & Outlet & 10 June 1993 & 620 & 7.5 & 2.98 & 231.5 \\
\hline & Outlet & 10 June 1993 & 620 & 7.5 & 3.01 & 205.1 \\
\hline & Inlet & 10 June 1993 & 620 & 3.0 & 2.84 & 214.9 \\
\hline & Inlet & 10 June 1993 & 620 & 3.0 & 2.81 & 228.4 \\
\hline & Inlet & 10 June 1993 & 620 & 3.0 & 2.69 & 199.1 \\
\hline \multirow{3}{*}{$\cdots$} & Outlet & 10 June 1993 & 620 & 3.0 & 3.16 & 192.6 \\
\hline & Outlet & 10 June 1993 & 620 & 3.0 & 3.87 & 209.4 \\
\hline & Outlet & 10 June 1993 & 620 & 3.0 & 3.06 & 214 \\
\hline \multirow[t]{17}{*}{ E } & Inlet & 9 June 1993 & 750 & 0.60 & 2.08 & 275.6 \\
\hline & Inlet & 9 June 1993 & 750 & 0.60 & 2.19 & 278.3 \\
\hline & Inlet & 9 June 1993 & 750 & 0.60 & 2.15 & 216.9 \\
\hline & Outlet & 9 June 1993 & 750 & 0.60 & 2.68 & 233 \\
\hline & Outlet & 9 June 1993 & 750 & 0.60 & 3.57 & 232.8 \\
\hline & Outlet & 9 June 1993 & 750 & 0.60 & 2.85 & 244.3 \\
\hline & Inlet & 9 June 1993 & 750 & 0.24 & 2.18 & 212.7 \\
\hline & Inlet & 9 June 1993 & 750 & 0.24 & 2.12 & 192.3 \\
\hline & Inlet & 9 June 1993 & 750 & 0.24 & 2.2 & 199.2 \\
\hline & Outlet & 9 June 1993 & 750 & 0.24 & 3.28 & 210.7 \\
\hline & Outlet & 9 June 1993 & 750 & 0.24 & 3.24 & 214 \\
\hline & Outlet & 9 June 1993 & 750 & 0.24 & 3.31 & 203.5 \\
\hline & Inlet & 10 June 1993 & 620 & 0.60 & 2.39 & 225.1 \\
\hline & Inlet & 10 June 1993 & 620 & 0.60 & 2.46 & 227.8 \\
\hline & Inlet & 10 June 1993 & 620 & 0.60 & 2.5 & 212.8 \\
\hline & Outlet & 10 June 1993 & 620 & 0.60 & 2.98 & 232.6 \\
\hline & Outlet & 10 June 1993 & 620 & 0.60 & 3.03 & 263.5 \\
\hline
\end{tabular}


Table A-5 (continued)

\begin{tabular}{|c|c|c|c|c|c|c|}
\hline Bieactor & Pasition & Date & $\begin{array}{c}\text { Temperature, } \\
\circ \mathrm{F} \\
\end{array}$ & $\begin{array}{c}\text { Flow Rate, } \\
\text { kwscfm }\end{array}$ & $\begin{array}{c}\mathrm{O}_{2}, \\
\text { Volume \% } \\
\end{array}$ & $\begin{array}{c}\mathrm{NH}_{3} \text {, wppmv } \\
\text { O } 3 \% \mathrm{Q}\end{array}$ \\
\hline \multirow[t]{7}{*}{$\mathrm{E}$} & Outlet & 10 June 1993 & 620 & 0.60 & 3.04 & 256.8 \\
\hline & Inlet & 10 June 1993 & 620 & 0.24 & 2.67 & 186.2 \\
\hline & Inlet & 10 June 1993 & 620 & 0.24 & 3.66 & 228.7 \\
\hline & Inlet & 10 June 1993 & 620 & 0.24 & 3.51 & 243.2 \\
\hline & Outlet & 10 June 1993 & 620 & 0.24 & 3.55 & 237.6 \\
\hline & Outlet & 10 June 1993 & 620 & 0.24 & 3.56 & 252.5 \\
\hline & Outlet & 10 Inne 1993 & 620 & 024 & 345 & 2362 \\
\hline
\end{tabular}


Table A-6. $\mathrm{SO}_{2}$ Oxidation Test Data

\begin{tabular}{|c|c|c|c|c|c|c|c|c|c|}
\hline \multirow[b]{3}{*}{ Reactor } & \multirow[b]{3}{*}{ Date } & \multicolumn{4}{|c|}{ Target Reactor Operating Conditions } & \multirow{2}{*}{\multicolumn{2}{|c|}{$\mathrm{SO}_{2}, \mathrm{dppmv} @ 3 \% \mathrm{O}_{2}$}} & \multirow{2}{*}{\multicolumn{2}{|c|}{$\mathrm{SO}_{3}$, dppmv @ 3\% O }} \\
\hline & & \multirow{2}{*}{$\begin{array}{c}\text { Test } \\
\text { Condition Code } \\
\end{array}$} & \multirow[b]{2}{*}{ Temp., ${ }^{\circ} \mathbf{F}$} & \multirow{2}{*}{$\begin{array}{c}\text { Gas Rate, } \\
\text { kwscfm }\end{array}$} & \multirow[b]{2}{*}{$\mathrm{NH}_{3} / \mathrm{NO}_{\mathbf{x}}$} & & & & \\
\hline & & & & & & Inlet & Outlet & Inlet & Outlet \\
\hline \multirow[t]{9}{*}{ A } & $8 / 6 / 93$ & 22 & 700 & 5.0 & 0.8 & 2,240 & 2,330 & 11.1 & 26.8 \\
\hline & $8 / 6 / 93$ & 17 & 700 & 3.0 & 0.8 & 2,590 & 2,418 & 8.3 & 38.1 \\
\hline & $8 / 9 / 93$ & 7 & 620 & 5.0 & 0.8 & 2,113 & 2,198 & 10.0 & 11.5 \\
\hline & $8 / 9 / 93$ & 27 & 700 & 7.3 & 0.8 & 2,084 & 2,075 & 12.7 & 34.4 \\
\hline & $8 / 10 / 93$ & 37 & 750 & 5.0 & 0.8 & 1,952 & 1,970 & 9.2 & 50 \\
\hline & $8 / 11 / 93$ & 42 & 750 & 7.3 & 0.8 & 2,122 & 2,234 & 14.7 & 40.6 \\
\hline & $8 / 11 / 93$ & 32 & 750 & 3.0 & 0.8 & 2,246 & 1,993 & 9.8 & 53.1 \\
\hline & $8 / 12 / 93$ & 2 & 620 & 3.0 & 0.8 & 1,892 & 2,093 & 11.3 & 15.1 \\
\hline & $8 / 12 / 93$ & 12 & 620 & 7.3 & 0.8 & 1,997 & 2,159 & 8.9 & 8.1 \\
\hline \multirow[t]{11}{*}{ B } & $7 / 13 / 93$ & 22 & 700 & 5.0 & 0.8 & 1,982 & 2,007 & 11.2 & 12.0 \\
\hline & $7 / 21 / 93$ & 12 & 620 & 7.3 & 0.8 & 2,287 & 3,189 & 10.3 & 8.4 \\
\hline & $7 / 21 / 93$ & 2 & 620 & 3.0 & 0.8 & 2,555 & 2,443 & 12.2 & 8.9 \\
\hline & $7 / 22 / 93$ & 27 & 700 & 7.3 & 0.8 & 2,061 & 2,029 & 13.1 & 22.0 \\
\hline & $7 / 22 / 93$ & 17 & 700 & 3.0 & 0.8 & 1,918 & 2,135 & 12.5 & 20.9 \\
\hline & $7 / 23 / 93$ & 32 & 750 & 3.0 & 0.8 & 2,213 & 2,061 & 20.5 & 34.1 \\
\hline & $7 / 26 / 93$ & 42 & 750 & 7.5 & 0.8 & 2,363 & 2,449 & 16.7 & 22.6 \\
\hline & $7 / 26 / 93$ & 37 & 750 & 5.0 & 0.8 & 2,392 & 2,495 & 14.1 & 27.1 \\
\hline & $7 / 27 / 93$ & 7 & 620 & 5.0 & 0.8 & 2,086 & 2,491 & 10.6 & 6.1 \\
\hline & $8 / 3 / 93$ & 12 & 620 & 7.3 & 0.8 & 1,906 & 1,985 & 7.7 & 12.4 \\
\hline & $8 / 3 / 93$ & 27 & 700 & 7.3 & 0.8 & 2,024 & 1,943 & 5.8 & 8.7 \\
\hline
\end{tabular}


Table A-6 (continued)

\begin{tabular}{|c|c|c|c|c|c|c|c|c|c|}
\hline \multirow[b]{3}{*}{ Reactor } & \multirow[b]{3}{*}{ Date } & \multicolumn{4}{|c|}{ Target Reactor Operating Conditions } & \multirow{2}{*}{\multicolumn{2}{|c|}{$\mathrm{SO}_{2}$, dppmv@3\% $\mathrm{O}_{2}$}} & \multirow{2}{*}{\multicolumn{2}{|c|}{$\mathrm{SO}_{3}$, dppmv@3\% $\mathrm{O}$}} \\
\hline & & \multirow{2}{*}{$\begin{array}{c}\text { Test } \\
\text { Condition Code }\end{array}$} & \multirow[b]{2}{*}{ Temp., ${ }^{\circ} \mathbf{F}$} & \multirow{2}{*}{$\begin{array}{c}\text { Gas Rate, } \\
\text { kwscfm }\end{array}$} & \multirow[b]{2}{*}{$\mathrm{NH}_{3} / \mathrm{NO}_{\mathrm{x}}$} & & & & \\
\hline & & & & & & Inlet & Outlet & Inlet & Outlet \\
\hline \multirow[t]{15}{*}{$\mathrm{C}$} & $7 / 12 / 93$ & 22 & 700 & 5.0 & 0.8 & 2,025 & 2,186 & 11.4 & 37.3 \\
\hline & $7 / 27 / 93$ & 27 & 700 & 7.3 & 0.8 & $-{ }^{a}$ & 2,571 & - & 21.4 \\
\hline & $7 / 28 / 93$ & 2 & 620 & 3.0 & 0.8 & - & 2,230 & - & 8.5 \\
\hline & $7 / 28 / 93$ & 7 & 620 & 5.0 & 0.8 & - & 2,486 & - & 10.4 \\
\hline & $7 / 28 / 93$ & 12 & 620 & 7.5 & 0.8 & - & 2,591 & - & 8.0 \\
\hline & $7 / 29 / 93$ & 37 & 750 & 5.0 & 0.8 & - & 2,208 & - & 72.5 \\
\hline & $7 / 29 / 93$ & 42 & 750 & 7.5 & 0.8 & - & 2,448 & - & 51.5 \\
\hline & $7 / 30 / 93$ & 32 & 750 & 3.0 & 0.8 & - & 2,395 & - & 77.5 \\
\hline & $7 / 30 / 93$ & 17 & 700 & 3.0 & 0.8 & - & 2,469 & - & 45.1 \\
\hline & $8 / 5 / 93$ & $\cdot 7$ & 620 & 5.0 & 0.8 & - & 2,463 & - & - \\
\hline & $8 / 5 / 93$ & 12 & 620 & 7.5 & 0.8 & - & 2,527 & - & - \\
\hline & $8 / 5 / 93$ & 2 & 620 & 3.0 & 0.8 & - & 2,401 & - & 6.4 \\
\hline & $8 / 13 / 93$ & 32 & 750 & 3.0 & 0.8 & 2,272 & 2,107 & 15.3 & 75.2 \\
\hline & $8 / 13 / 93$ & 37 & 750 & 5.0 & 0.8 & 2,148 & 2,261 & 12.1 & 54.7 \\
\hline & $8 / 13 / 93$ & 42 & 750 & 7.5 & 0.8 & 2,237 & 2,201 & 14.0 & 58.5 \\
\hline
\end{tabular}

${ }^{a}$ Dash indicates that no tests were performed at these conditions. 
Table A-7. Parametric Test Data-Test Sequence 1

\begin{tabular}{|c|c|c|c|c|c|c|c|c|c|c|}
\hline \multirow[b]{2}{*}{ Reactor } & \multirow[b]{2}{*}{ Date } & \multirow[b]{2}{*}{ Location } & \multicolumn{4}{|c|}{ Target Reactor Operating Conditions } & \multicolumn{4}{|c|}{ Average Concentration, dppmv @ $3 \% \mathrm{O}_{2}$} \\
\hline & & & $\begin{array}{c}\text { Test } \\
\text { Condition Code }\end{array}$ & $\underset{{ }^{\circ}}{\text { Temp., }}$ & $\begin{array}{l}\text { Gas Rate, } \\
\text { kwscfm }\end{array}$ & $\mathrm{NH}_{3} / \mathrm{NOX}$ & $\mathrm{NH}_{1}$ & So, & $\mathrm{SO}_{3}$ & $\mathrm{HCl}$ \\
\hline \multirow[t]{15}{*}{ A } & 16Aug93 & Outlet & 16 & 700 & 3.0 & 0.6 & 1.0 & $--^{a}$ & - & - \\
\hline & 17Aug93 & Outlet & 26 & 700 & 7.3 & 0.6 & 0.8 & - & - & - \\
\hline & 18Aug93 & Outlet & 19 & 700 & 3.0 & 1.0 & 2.1 & - & - & - \\
\hline & 23 Sep93 & Outlet & 14 & 620 & 7.5 & 1.0 & 28.4 & - & - & - \\
\hline & $23 \mathrm{Sep} 93$ & Outlet & 22 & 700 & 5.0 & 0.8 & 6.0 & - & - & - \\
\hline & 10Sep93 & Outlet & 1 & 620 & 3.0 & 0.6 & - & 2,108 & 6.1 & - \\
\hline & 10Sep93 & Outlet & 4 & 620 & 3.0 & 1.0 & - & 1,944 & 9.2 & - \\
\hline & 13Sep93 & Outlet & 11 & 620 & 7.5 & 0.6 & - & 1,976 & 8.6 & - \\
\hline & $13 \mathrm{Sep} 93$ & Outlet & 14 & 620 & 7.5 & 1.0 & - & 2,008 & 3.4 & - \\
\hline & $24 \operatorname{Sep} 93$ & Outlet & 22 & 700 & 5.0 & 0.8 & - & 2,019 & 14.7 & - \\
\hline & 24Sep93 & Outlet & 31 & 750 & 3.0 & 0.6 & - & 2,082 & 58.7 & - \\
\hline & $24 \operatorname{Sep} 93$ & Outlet & 34 & 750 & 3.0 & 1.0 & - & 1,911 & 43.8 & - \\
\hline & 24Sep93 & Outlet & 41 & 750 & 6.8 & 0.6 & - & 2,077 & 30.2 & - \\
\hline & 27Sep93 & Outlet & 44 & 750 & 7.1 & 1.0 & - & 1,430 & 14.5 & - \\
\hline & 06Aug93 & Outlet & 22 & 700 & 5.0 & 0.8 & - & - & - & 178 \\
\hline \multirow[t]{11}{*}{ B } & 04Aug93 & Outlet & 22 & 700 & 5.0 & 0.8 & 6.8 & - & - & - \\
\hline & 17Aug93 & Outlet & 19 & 700 & 3.0 & 1.0 & 1.8 & - & - & - \\
\hline & 17Aug93 & Outlet & 22 & 700 & 5.0 & 0.8 & 0.7 & - & - & - \\
\hline & 19Aug93 & Outlet & 26 & 700 & 7.5 & 0.6 & 0.9 & - & - & - \\
\hline & 22Sep93 & Outlet & 14 & 620 & 7.5 & 1.0 & 35.3 & - & - & - \\
\hline & 23Sep93 & Outlet & 22 & 700 & 5.0 & 0.8 & 1.0 & - & - & - \\
\hline & 08Sep93 & Outlet & 1 & 620 & 3.0 & 0.6 & - & 1,994 & 6.2 & - \\
\hline & 09Sep93 & Outlet & 4 & 620 & 3.0 & 1.0 & - & 2,064 & 4.6 & - \\
\hline & 13Sep93 & Outlet & 11 & 620 & 7.5 & 0.6 & - & 2,046 & 6.8 & - \\
\hline & 13 Sep 93 & Outlet & 14 & 620 & 7.5 & 1.0 & - & 2,105 & 2.6 & - \\
\hline & 24Sep93 & Outlet & 22 & 700 & 5.0 & 0.8 & - & 1,438 & 2.2 & - \\
\hline
\end{tabular}


Table A-7 (continued)

\begin{tabular}{|c|c|c|c|c|c|c|c|c|c|c|}
\hline \multirow[b]{2}{*}{ Reactor } & \multirow[b]{2}{*}{ Date } & \multirow[b]{2}{*}{ Location } & \multicolumn{4}{|c|}{ Target Reactor Operating Conditions } & \multicolumn{4}{|c|}{ Average Concentration, dppmv @ $3 \% \mathrm{O}_{2}$} \\
\hline & & & $\begin{array}{c}\text { Test } \\
\text { Condition Code } \\
\end{array}$ & $\begin{array}{c}\text { Temp., } \\
{ }^{\circ} \mathbf{F}\end{array}$ & $\begin{array}{c}\text { Gas Rate, } \\
\text { kwscfm }\end{array}$ & $\mathrm{NH}_{3} / \mathrm{NOx}$ & $\mathrm{NH}_{3}$ & SO, & $\mathrm{SO}_{3}$ & $\underline{\mathrm{HCl}}$ \\
\hline \multirow[t]{5}{*}{ B } & $10 \operatorname{Sep} 93$ & Outlet & 31 & 850 & 3.0 & 0.9 & - & 1,901 & 26.4 & - \\
\hline & $10 \operatorname{Sep} 93$ & Outlet & 34 & 750 & 3.0 & 1.0 & - & 1,840 & 18.3 & - \\
\hline & 09Sep93 & Outlet & 41 & 750 & 7.5 & 0.6 & - & 2,029 & 23.4 & - \\
\hline & 09Sep93 & Outlet & 44 & 750 & 7.5 & 1.0 & - & 2,029 & 10.0 & - \\
\hline & 16Ju193 & Outlet & 22 & 700 & 5.0 & 0.8 & - & - & - & 152 \\
\hline \multirow[t]{19}{*}{$\mathrm{C}$} & 18Aug93 & Outlet & 16 & 700 & 3.0 & 0.6 & 1.0 & - & - & - \\
\hline & 19Aug93 & Outlet & 16 & 700 & 3.0 & 0.6 & 2.8 & - & - & - \\
\hline & 12Aug93 & Outlet & 16 & 700 & 3.0 & 0.6 & 0.8 & - & - & - \\
\hline & 12Aug93 & Outlet & 26 & 700 & 7.5 & 0.6 & 2.9 & - & - & - \\
\hline & 17Aug93 & Outlet & 19 & 700 & 3.0 & 1.0 & 16.5 & - & - & - \\
\hline & 21Sep93 & Outlet & 14 & 620 & 7.5 & 1.0 & 58.0 & - & - & - \\
\hline & 23Sep93 & Outlet & 22 & 700 & 5.0 & 0.8 & 5.4 & - & - & - \\
\hline & 08Sep93 & Outlet & 1 & 620 & 3.0 & 0.6 & - & 2,194 & 20.1 & - \\
\hline & 09Sep93 & Outlet & 4 & 620 & 3.0 & 1.0 & - & 2,006 & 6.8 & - \\
\hline & 24Sep93 & Outlet & 11 & 620 & 7.5 & 0.6 & - & 1,443 & 2.7 & - \\
\hline & 10Sep93 & Outlet & 14 & 620 & 7.5 & 1.0 & - & 2,114 & 6.5 & - \\
\hline & 27Sep93 & Outlet & 22 & 700 & 5.0 & 0.8 & - & 1,837 & 32.2 & - \\
\hline & 08 Sep93 & Outlet & 31 & 750 & 3.0 & 0.6 & - & 1,969 & 68.3 & - \\
\hline & 13Sep 93 & Outlet & 34 & 750 & 3.0 & 1.0 & - & 1,965 & 56.8 & - \\
\hline & 13Sep93 & Outlet & 41 & 750 & 7.5 & 0.6 & - & 2,057 & 40.4 & - \\
\hline & 10Sep93 & Outlet & 44 & 750 & 7.5 & 1.0 & - & 1,986 & 29.0 & - \\
\hline & $14 \mathrm{Jul} 93$ & Outlet & 22 & 700 & 5.0 & 0.8 & - & - & - & 137 \\
\hline & $15 \mathrm{Jul} 93$ & Outlet & 22 & 700 & 5.0 & 0.8 & - & - & - & 143 \\
\hline & 19Jul93 & Outlet & 22 & 700 & 5.0 & 0.8 & - & - & - & 125 \\
\hline \multirow[t]{2}{*}{$\mathrm{D}$} & $25 \mathrm{Oct} 93$ & Outlet & 14 & 620 & 0.60 & 1.0 & 90.4 & - & - & - \\
\hline & $260 c t 93$ & Outlet & 22 & 700 & 0.40 & 0.8 & 2.8 & - & - & - \\
\hline
\end{tabular}


Table A-7 (continued)

\begin{tabular}{|c|c|c|c|c|c|c|c|c|c|c|}
\hline \multirow[b]{2}{*}{ Reactor } & \multirow[b]{2}{*}{ Date } & \multirow[b]{2}{*}{ Location } & \multicolumn{4}{|c|}{ Target Reactor Operating Conditions } & \multicolumn{4}{|c|}{ Average Concentration, dppmv @ $3 \% \mathrm{O}_{2}$} \\
\hline & & & $\begin{array}{c}\text { Test } \\
\text { Condition Code } \\
\end{array}$ & $\begin{array}{c}\text { Temp., } \\
{ }^{\circ} \mathbf{F}\end{array}$ & $\begin{array}{c}\text { Gas Rate, } \\
\text { kwscfm }\end{array}$ & $\mathrm{NH}_{2} / \mathrm{NOx}$ & $\mathrm{NH}_{3}$ & $\mathrm{SO}_{2}$ & $\mathrm{SO}_{3}$ & $\mathrm{HCI}$ \\
\hline \multirow[t]{7}{*}{$\mathrm{D}$} & $200 c t 93$ & Outlet & 1 & 620 & 0.24 & 0.6 & - & 2,336 & 7.7 & - \\
\hline & $210 \mathrm{ct} 93$ & Outlet & 22 & 700 & 0.40 & 0.8 & - & 2,096 & 26.5 & - \\
\hline & $150 c t 93$ & Outlet & 31 & 750 & 0.24 & 0.6 & - & 1,717 & 34.8 & - \\
\hline & 220 ct93 & Outlet & 34 & 750 & 0.24 & 1.0 & - & 2,578 & 49.6 & - \\
\hline & $190 \mathrm{ct} 93$ & Outlet & 41 & 750 & 0.60 & 0.6 & - & 1,886 & 25.6 & - \\
\hline & $190 c t 93$ & Outlet & 44 & 750 & 0.60 & 1.0 & - & 1,902 & 17.4 & - \\
\hline & 27 Oct93 & Outlet & 1 & 700 & 0.40 & 0.8 & - & - & - & 135 \\
\hline \multirow[t]{9}{*}{$\mathrm{E}$} & 25 Oct 93 & Outlet & 14 & 620 & 0.60 & 1.0 & 68.0 & - & - & - \\
\hline & $260 c t 93$ & Outlet & 22 & 700 & 0.40 & 0.8 & $<0.13$ & - & - & - \\
\hline & $200 c t 93$ & Outlet & 1 & 620 & 0.24 & 0.6 & - & 2,104 & 6.9 & - \\
\hline & $210 \mathrm{ct} 93$ & Outlet & 22 & 700 & 0.40 & 0.8 & - & 2,058 & 15.8 & - \\
\hline & 220 ct93 & Outlet & 31 & 750 & 0.24 & 0.6 & - & 2,360 & 38.7 & - \\
\hline & $220 c t 93$ & Outlet & 34 & 750 & 0.24 & 1.0 & - & 2,073 & 16.0 & - \\
\hline & $190 \mathrm{ct} 93$ & Outlet & 41 & 750 & 0.60 & 0.6 & - & 1,855 & 15.2 & - \\
\hline & $190 \mathrm{ct} 93$ & Outlet & 44 & 750 & 0.60 & 1.0 & - & 1,925 & 9.8 & - \\
\hline & 27 Oct93 & Outlet & 22 & 700 & 0.40 & 0.8 & - & - & - & 211 \\
\hline \multirow[t]{9}{*}{$\mathrm{F}$} & $250 \mathrm{Oct} 93$ & Outlet & 14 & 620 & 0.60 & 1.0 & 32.5 & - & - & - \\
\hline & $260 c t 93$ & Outlet & 22 & 700 & 0.40 & 0.8 & 76.7 & - & - & - \\
\hline & $200 c t 93$ & Outlet & 1 & 620 & 0.24 & 0.6 & - & 1,808 & 3.6 & - \\
\hline & $210 c t 93$ & Outlet & 22 & 700 & 0.40 & 0.8 & - & 1,806 & 8.7 & - \\
\hline & $220 c t 93$ & Outlet & 31 & 750 & 0.24 & 0.6 & - & 2,006 & 12.0 & - \\
\hline & 220 ct93 & Outlet & 34 & 750 & 0.24 & 1.0 & - & 2,028 & 10.0 & - \\
\hline & $190 \mathrm{ct} 93$ & Outlet & 41 & 750 & 0.60 & 0.6 & - & $1 ; 679$ & 10.1 & - \\
\hline & $190 \mathrm{ct} 93$ & Outlet & 44 & 750 & 0.60 & 1.0 & - & 1,690 & 7.1 & - \\
\hline & 27 Oct93 & Outlet & 1 & 700 & 0.40 & 0.8 & - & - & - & 202 \\
\hline
\end{tabular}

${ }^{\mathrm{a}}$ Dash indicates that no tests were performed at these conditions. 
Table A-8. Parametric Test Data-Test Sequence 2

\begin{tabular}{|c|c|c|c|c|c|c|c|c|c|c|c|c|c|}
\hline \multirow[b]{2}{*}{ Reactor } & \multirow[b]{2}{*}{ Date } & \multirow[b]{2}{*}{ Location } & \multicolumn{4}{|c|}{ Target Reactor Operating Conditions } & \multirow{2}{*}{$\begin{array}{c}\text { Inlet } \\
\text { NOx, } \\
\text { wppmv }\end{array}$} & \multirow{2}{*}{$\begin{array}{c}\text { Outlet } \\
\text { NOx, } \\
\text { wppmv }\end{array}$} & \multicolumn{5}{|c|}{$\begin{array}{c}\text { Average Concentration, } \\
\text { dppmv@ } 3 \% \mathrm{O}_{2}\end{array}$} \\
\hline & & & $\begin{array}{c}\text { Test } \\
\text { Condition Code }\end{array}$ & $\begin{array}{c}\text { Temp., } \\
{ }^{\circ} \mathrm{F}\end{array}$ & $\begin{array}{l}\text { Flue Gas, } \\
\text { kwsefm }\end{array}$ & $\mathbf{N H}_{\mathbf{3}} / \mathrm{NOx}$ & & & $\mathrm{NH}_{3}$ & $\mathrm{SO}_{2}$ & $\mathrm{SO}_{3}$ & $\mathbf{H C l}$ & $\mathrm{N}_{2} \mathrm{O}$ \\
\hline \multirow[t]{18}{*}{ A } & $16 \operatorname{Dec} 93$ & Outlet & 22 & 700 & 5.0 & 0.8 & $--^{a}$ & - & 1.8 & - & - & - & - \\
\hline & 05Jan94 & Outlet & 22 & 700 & 5.0 & 0.8 & - & - & 2.6 & - & - & - & - \\
\hline & 10Jan94 & Outlet & 7 & 620 & 5.0 & 0.8 & - & - & 5.7 & - & - & - & - \\
\hline & 10Jan94 & Outlet & 12 & 620 & 7.0 & 0.8 & - & - & 9.8 & - & - & - & - \\
\hline & 12Jan 94 & Outlet & 14 & 620 & 7.1 & 1.0 & - & - & 29 & - & - & - & - \\
\hline & 07Jan94 & Outlet & 22 & 700 & 5.0 & 0.8 & - & - & 2.7 & - & - & - & - \\
\hline & 07Jan94 & Outlet & 27 & 700 & 6.3 & 0.8 & - & - & 4.5 & - & - & - & - \\
\hline & 11Jan94 & Outlet & 42 & 750 & 6.0 & 0.8 & - & - & 2.9 & - & - & - & - \\
\hline & 27Jan94 & Outlet & 2 & 620 & 3.0 & 0.8 & - & - & - & 1,733 & 10.2 & - & - \\
\hline & 27Jan94 & Outlet & 17 & 700 & 3.0 & 0.8 & - & - & - & 1,653 & 28.8 & - & - \\
\hline & 26Jan94 & Outlet & 22 & 700 & 5.0 & 0.8 & - & - & - & 1,672 & 11.5 & - & - \\
\hline & 26Jan94 & Outlet & 27 & 700 & 6.8 & 0.8 & - & - & - & 1,654 & 11.7 & - & - \\
\hline & $25 \operatorname{Jan} 94$ & Outlet & 32 & 750 & 3.0 & 0.8 & - & - & - & 1,613 & 27.0 & - & - \\
\hline & $25 \operatorname{Jan} 94$ & Outlet & 37 & 750 & 5.0 & 0.8 & - & - & - & 1,320 & 34.8 & - & - \\
\hline & $28 \operatorname{Jan} 94$ & Outlet & 42 & 750 & 6.1 & 0.8 & - & - & - & 1,615 & 19.7 & - & - \\
\hline & $28 \operatorname{Jan} 94$ & Outlet & 22 & 700 & 5.0 & 0.8 & - & - & - & - & - & 241 & - \\
\hline & 20Apr 94 & Inlet & - & - & - & - & 310 & - & - & - & - & - & 2.4 \\
\hline & 20 Apr 94 & Outlet & 22 & 700 & 5.0 & 0.8 & 310 & - & - & - & - & - & 1.2 \\
\hline \multirow[t]{7}{*}{ B } & $15 \operatorname{Dec} 93$ & Outlet & 22 & 700 & 5.0 & 0.8 & - & - & 2.9 & - & - & - & - \\
\hline & 10Jan94 & Outlet & 7 & 620 & 5.0 & 0.8 & - & - & $<0.81$ & - & - & - & - \\
\hline & 10Jan94 & Outlet & 12 & 620 & 7.0 & 0.8 & - & - & 2.4 & - & - & - & - \\
\hline & 12Jan94 & Outlet & 14 & 620 & 7.0 & 1.0 & - & - & 7.2 & - & - & - & - \\
\hline & 05Jan94 & Outlet & 22 & 700 & 5.0 & 0.8 & - & - & 0.7 & - & - & - & - \\
\hline & 07Jan94 & Outlet & 22 & 700 & 5.0 & 0.8 & - & - & $<0.8$ & - & - & - & - \\
\hline & 07Jan94 & Outlet & 27 & 700 & 6.6 & 0.8 & - & - & 0.9 & - & - & - & - \\
\hline
\end{tabular}


Table A-8 (continued)

\begin{tabular}{|c|c|c|c|c|c|c|c|c|c|c|c|c|c|}
\hline \multirow[b]{2}{*}{ Reactor } & \multirow[b]{2}{*}{ Date } & \multirow[b]{2}{*}{ Location } & \multicolumn{4}{|c|}{ Target Reactor Operating Conditions } & \multirow{2}{*}{$\begin{array}{c}\text { Inlet } \\
\text { NOx, } \\
\text { wppmv }\end{array}$} & \multirow{2}{*}{$\begin{array}{c}\text { Outlet } \\
\text { NOx, } \\
\text { wppmv }\end{array}$} & \multicolumn{5}{|c|}{$\begin{array}{c}\text { Average Concentration, } \\
\text { dppmv @ } 3 \% \mathrm{O}_{2}\end{array}$} \\
\hline & & & $\begin{array}{c}\text { Test } \\
\text { Condition Code }\end{array}$ & $\begin{array}{c}\text { Temp., } \\
{ }^{\circ} \mathrm{F}\end{array}$ & $\begin{array}{c}\text { Flue Gas, } \\
\text { kwscfm }\end{array}$ & $\mathrm{NH}_{3} / \mathrm{NOx}$ & & & $\mathbf{N H}_{3}$ & $\mathrm{SO}_{2}$ & $\mathrm{SO}_{3}$ & $\mathbf{H C l}$ & $\mathbf{N}_{2} \mathbf{O}$ \\
\hline \multirow[t]{11}{*}{$\mathrm{B}$} & 11Jan94 & Outlet & 42 & 750 & 6.5 & 0.8 & - & - & 0.9 & - & - & - & - \\
\hline & 17Mar94 & Outlet & 2 & 620 & 3.0 & 0.8 & - & - & - & 2,115 & 4.6 & - & - \\
\hline & 17Mar94 & Outlet & 17 & 700 & 3.0 & 0.8 & - & - & - & 2,184 & 25.0 & - & - \\
\hline & $18 \mathrm{Mar} 94$ & Outlet & 22 & 700 & 5.0 & 0.8 & - & - & - & 2,236 & 8.4 & - & - \\
\hline & $21 \mathrm{Mar} 94$ & Outlet & 27 & 700 & 6.6 & 0.8 & - & - & - & 2,127 & 5.7 & - & - \\
\hline & 21Mar94 & Outlet & 32 & 750 & 3.0 & 0.8 & - & - & - & 2,084 & 22.8 & - & - \\
\hline & 21Mar94 & Outlet & 37 & 750 & 5.0 & 0.8 & - & - & - & 2,109 & 14.5 & - & - \\
\hline & 21Mar94 & Outlet & 42 & 750 & 6.6 & 0.8 & - & - & - & 2,076 & 17.4 & - & - \\
\hline & $01 \mathrm{Feb} 94$ & Outlet & 22 & 700 & - & 0.8 & - & - & - & - & - & 158 & - \\
\hline & 20Apr94 & Inlet & - & - & - & - & 310 & - & - & - & - & - & 2.4 \\
\hline & 20Apr94 & Outlet & 22 & 700 & 5 & 0.8 & 297 & - & - & - & - & - & 1.0 \\
\hline \multirow[t]{14}{*}{$\mathrm{C}$} & 15 Dec 93 & Outlet & 22 & 700 & 5.0 & 0.8 & - & - & 2.7 & - & - & - & - \\
\hline & 12Jan 94 & Outlet & 7 & 620 & 5.0 & 0.8 & - & - & 2.8 & - & - & - & - \\
\hline & 12Jan94 & Outlet & 12 & 620 & 7.5 & 0.8 & - & - & 7 & - & - & - & - \\
\hline & 13Jan94 & Outlet & 14 & 620 & 7.5 & 1.0 & - & - & 14.1 & - & - & - & - \\
\hline & 05Jan94 & Outlet & 22 & 700 & 5.0 & 0.8 & - & - & 1.4 & - & - & - & - \\
\hline & 05Jan94 & Outlet & 27 & 700 & 7.4 & 0.8 & - & - & 3.1 & - & - & - & - \\
\hline & 11Jan94 & Outlet & 42 & 750 & 7.2 & 0.8 & - & - & 4.4 & - & - & - & - \\
\hline & 26Jan94 & Outlet & 2 & 620 & 3.0 & 0.8 & - & - & - & 1,725 & 8.9 & - & - \\
\hline & 26Jan94 & Outlet & 17 & 700 & 3.0 & 0.8 & - & - & - & 1,670 & 32.2 & - & - \\
\hline & 27Jan94 & Outlet & 22 & 700 & 5.0 & 0.8 & - & - & - & 1,682 & 24.8 & - & - \\
\hline & $27 \operatorname{Jan} 94$ & Outlet & 27 & 700 & 7.5 & 0.8 & - & - & - & 1,650 & 12.3 & - & - \\
\hline & $25 \mathrm{Jan} 94$ & Outlet & 32 & 750 & 3.0 & 0.8 & - & - & - & 1,643 & 65.1 & - & - \\
\hline & $25 \operatorname{Jan} 94$ & Outlet & 37 & 750 & 5.0 & 0.8 & - & - & - & 1,638 & 49.9 & - & - \\
\hline & 24Jan94 & Outlet & 42 & 750 & 7.3 & 0.8 & - & - & - & 1,720 & 33 & - & - \\
\hline
\end{tabular}


Table A-8 (continued)

\begin{tabular}{|c|c|c|c|c|c|c|c|c|c|c|c|c|c|}
\hline \multirow[b]{2}{*}{ Reactor } & \multirow[b]{2}{*}{ Date } & \multirow[b]{2}{*}{ Location } & \multicolumn{4}{|c|}{ Target Reactor Operating Conditions } & \multirow{2}{*}{$\begin{array}{c}\text { Inlet } \\
\text { NOx, } \\
\text { wppmv }\end{array}$} & \multirow{2}{*}{$\begin{array}{c}\text { Outlet } \\
\text { NOx, } \\
\text { wppmv }\end{array}$} & \multicolumn{5}{|c|}{$\begin{array}{c}\text { Average Concentration, } \\
\text { dppmv @ } 3 \% \mathrm{O}_{2}\end{array}$} \\
\hline & & & $\begin{array}{c}\text { Test } \\
\text { Condition Code } \\
\end{array}$ & $\begin{array}{c}\text { Temp., } \\
{ }^{\circ} \mathrm{F} \\
\end{array}$ & $\begin{array}{c}\text { Flue Gas, } \\
\text { kwscfm }\end{array}$ & $\mathrm{NH}_{3} / \mathrm{NOx}$ & & & $\mathrm{NH}_{3}$ & $\mathrm{SO}_{2}$ & $\mathrm{SO}_{3}$ & $\mathbf{H C l}$ & $\mathbf{N}_{2} \mathrm{O}$ \\
\hline \multirow[t]{3}{*}{$\mathrm{C}$} & $28 \operatorname{Jan} 94$ & Outlet & 22 & 700 & 5 & 0.8 & - & - & - & 一 & - & 211 & - \\
\hline & 20Apr94 & Inlet & - & - & - & - & 310 & - & - & - & - & - & 2.4 \\
\hline & 20 Apr94 & Outlet & 22 & 700 & 5 & 0.8 & 299 & - & - & - & - & - & 1.7 \\
\hline \multirow[t]{17}{*}{$\mathrm{D}$} & $21 \operatorname{Dec} 93$ & Outlet & 22 & 700 & 0.40 & 0.8 & - & - & 3.1 & - & - & - & - \\
\hline & 08Apr94 & Outlet & 7 & 620 & 0.40 & 0.8 & - & - & $<1.3$ & - & - & - & - \\
\hline & 14Apr94 & Outlet & 12 & 620 & 0.60 & 0.8 & - & - & 36.1 & - & - & - & - \\
\hline & 14Apr94 & Outlet & 14 & 620 & 0.60 & 1.0 & - & - & 66.9 & - & - & - & - \\
\hline & 15Apr94 & Outlet & 22 & 700 & 0.40 & 0.8 & - & - & 4.0 & - & - & - & - \\
\hline & 15Apr94 & Outlet & 27 & 700 & 0.60 & 0.8 & - & - & 10.9 & - & - & - & - \\
\hline & 18Apr94 & Outlet & 42 & 750 & 0.60 & 0.8 & - & - & 15.4 & - & - & - & - \\
\hline & 03Mar94 & Outlet & 2 & 620 & 0.24 & 0.8 & - & - & - & 2,127 & 3.1 & - & - \\
\hline & $23 \mathrm{Feb} 94$ & Outlet & 17 & 700 & 0.24 & 0.8 & - & - & - & 1,834 & 25.7 & - & - \\
\hline & 02Feb94 & Outlet & 22 & 700 & 0.40 & 0.8 & - & - & - & 1,852 & 26.9 & - & - \\
\hline & 02Mar94 & Outlet & 27 & 700 & 0.60 & 0.8 & - & - & - & 1,981 & 11.2 & - & - \\
\hline & 02Mar94 & Outlet & 32 & 750 & 0.24 & 0.8 & - & - & - & 1,973 & 32.2 & - & - \\
\hline & $24 \mathrm{Feb} 94$ & Outlet & 37 & 750 & 0.40 & 0.8 & - & - & - & 1,809 & 28.9 & - & - \\
\hline & 01Mar94 & Outlet & 42 & 750 & 0.60 & 0.8 & - & - & - & 2,112 & 29.1 & - & - \\
\hline & 02Feb94 & Outlet & 22 & 700 & 0.40 & 0.8 & - & - & - & - & - & 163 & - \\
\hline & 19Apr94 & Inlet & - & - & - & - & 340 & - & - & - & - & - & 1.8 \\
\hline & 19Apr94 & Outlet & 22 & 700 & 0.40 & 0.8 & 325 & - & - & - & - & - & 1.8 \\
\hline \multirow[t]{5}{*}{$\mathrm{E}$} & 21Dec93 & Outlet & 22 & 700 & 0.40 & 0.8 & - & - & $<0.8$ & - & - & - & - \\
\hline & 01Apr94 & Outlet & 4 & 620 & 0.24 & 1.0 & - & - & 2.4 & - & - & - & - \\
\hline & 07Apr94 & Outlet & 7 & 620 & 0.40 & 0.8 & - & - & $<1.0$ & - & - & - & - \\
\hline & 04Apr94 & Outlet & 12 & 620 & 0.60 & 0.8 & - & - & 1.4 & - & - & - & - \\
\hline & 04Apr94 & Outlet & 14 & 620 & 0.60 & 1.0 & - & - & 7 & - & - & - & - \\
\hline
\end{tabular}


Table A-8 (continued)

\begin{tabular}{|c|c|c|c|c|c|c|c|c|c|c|c|c|c|}
\hline \multirow[b]{2}{*}{ Reactor } & \multirow[b]{2}{*}{ Date } & \multirow[b]{2}{*}{ Location } & \multicolumn{4}{|c|}{ Target Reactor Operating Conditions } & \multirow{2}{*}{$\begin{array}{c}\text { Inlet } \\
\text { NOx, } \\
\text { wppmv }\end{array}$} & \multirow{2}{*}{$\begin{array}{c}\text { Outlet } \\
\text { NOx, } \\
\text { wppmv }\end{array}$} & \multicolumn{5}{|c|}{$\begin{array}{l}\text { Average Concentration, } \\
\text { dppmv @ 3\% } \mathrm{O}_{2}\end{array}$} \\
\hline & & & $\begin{array}{c}\text { Test } \\
\text { Condition Code } \\
\end{array}$ & $\begin{array}{c}\text { Temp., } \\
{ }^{\circ} \mathbf{F}\end{array}$ & $\begin{array}{c}\text { Flue Gas, } \\
\text { kwscfm }\end{array}$ & $\mathrm{NH}_{\mathbf{3}} / \mathrm{NOx}$ & & & $\mathbf{N H}_{3}$ & $\mathrm{SO}_{2}$ & $\mathrm{SO}_{3}$ & $\mathbf{H C l}$ & $\mathrm{N}_{2} \mathrm{O}$ \\
\hline \multirow[t]{13}{*}{$\mathrm{E}$} & 05Apr94 & Outlet & 22 & 700 & 0.40 & 0.8 & - & - & $<1.3$ & - & - & - & - \\
\hline & 13Apr94 & Outlet & 27 & 700 & 0.60 & 0.8 & - & - & $<0.6$ & - & - & - & - \\
\hline & 05Apr94 & Outlet & 42 & 750 & 0.60 & 0.8 & - & - & $<1.2$ & - & - & - & - \\
\hline & 17Mar94 & Outlet & 2 & 620 & 0.24 & 0.8 & - & - & - & 2,111 & 13.9 & - & - \\
\hline & 14Mar94 & Outlet & 17 & 700 & 0.24 & 0.8 & - & - & - & 1,980 & 20.3 & - & - \\
\hline & 14Mar94 & Outlet & 22 & 700 & 0.40 & 0.8 & - & - & - & 2,013 & 26.7 & - & - \\
\hline & 17Mar94 & Outlet & 27 & 700 & 0.60 & 0.8 & - & - & - & 2,351 & 23.5 & - & - \\
\hline & 16Mar94 & Outlet & 32 & 750 & 0.24 & 0.8 & - & - & - & 2,132 & 36.9 & - & - \\
\hline & 16Mar94 & Outlet & 37 & 750 & 0.40 & 0.8 & - & - & - & 2,143 & 36.6 & - & - \\
\hline & 16Mar94 & Outlet & 42 & 750 & 0.60 & 0.8 & - & - & - & 2,187 & 37.9 & - & - \\
\hline & 17Mar94 & Outlet & 22 & 700 & 0.40 & 0.8 & $\div$ & - & - & - & - & 196 & - \\
\hline & 19Apr94 & Inlet & - & - & - & - & 340 & - & - & - & - & - & 1.8 \\
\hline & 19Apr94 & Outlet & 22 & 700 & 0.40 & 0.8 & 303 & - & - & - & - & - & 1.8 \\
\hline \multirow[t]{12}{*}{$F$} & $21 \mathrm{Dec} 93$ & Outlet & 22 & 700 & 0.40 & 0.8 & - & - & 1.0 & - & - & - & - \\
\hline & 04Apr94 & Outlet & 4 & 620 & 0.24 & 1 & - & - & 8.1 & - & - & - & - \\
\hline & 08Apr94 & Outlet & 7 & 620 & 0.40 & 0.8 & - & - & 1.2 & - & - & - & - \\
\hline & 14Apr94 & Outlet & 12 & 620 & 0.60 & 0.8 & - & - & 4.6 & - & - & - & - \\
\hline & 14Apr94 & Outlet & 14 & 620 & 0.60 & 1.0 & - & - & 22.9 & - & - & - & - \\
\hline & 13Apr94 & Outlet & 22 & 700 & 0.40 & 0.8 & - & - & 1.2 & - & - & - & - \\
\hline & 13Apr94 & Outlet & 27 & 700 & 0.60 & 0.8 & - & - & 2.9 & - & - & - & - \\
\hline & 07Apr94 & Outlet & 42 & 750 & 0.60 & 0.8 & - & - & 3.7 & - & - & - & - \\
\hline & 16Mar94 & Outlet & 2 & 620 & 0.24 & 0.8 & - & - & - & 2,165 & 9.7 & - & - \\
\hline & 16Mar94 & Outlet & 17 & 700 & 0.24 & 0.8 & - & - & - & 2,190 & 22.7 & - & - \\
\hline & 14Mar94 & Outlet & 22 & 700 & 0.40 & 0.8 & - & - & - & 1,961 & 16.9 & - & - \\
\hline & 14Mar94 & Outlet & 27 & 700 & 0.60 & 0.8 & - & - & - & 2,028 & 15.7 & - & - \\
\hline
\end{tabular}


Table A-8 (continued)

\begin{tabular}{|c|c|c|c|c|c|c|c|c|c|c|c|c|c|}
\hline \multirow[b]{2}{*}{ Reactor } & \multirow[b]{2}{*}{ Date } & \multirow[b]{2}{*}{ Location } & \multicolumn{4}{|c|}{ Target Reactor Operating Conditions } & \multirow{2}{*}{$\begin{array}{c}\text { Inlet } \\
\text { NOx, } \\
\text { wppmv }\end{array}$} & \multirow{2}{*}{$\begin{array}{l}\text { Outlet } \\
\text { NOx, } \\
\text { wppmv }\end{array}$} & \multicolumn{5}{|c|}{$\begin{array}{l}\text { Average Concentration, } \\
\text { dppmv @ 3\% O }\end{array}$} \\
\hline & & & $\begin{array}{c}\text { Test } \\
\text { Condition Code }\end{array}$ & $\begin{array}{c}\text { Temp., } \\
{ }^{\circ} \mathbf{F}\end{array}$ & $\begin{array}{c}\text { Flue Gas, } \\
\text { kwscfm }\end{array}$ & $\mathrm{NH}_{3} / \mathrm{NOx}$ & & & $\mathbf{N H}_{\mathbf{3}}$ & $\mathrm{SO}_{2}$ & $\mathrm{SO}_{3}$ & $\mathbf{H C l}$ & $\mathrm{N}_{2} \mathrm{O}$ \\
\hline \multirow[t]{6}{*}{ F } & 15Mar94 & Outlet & 32 & 750 & 0.24 & 0.8 & - & - & - & 2,015 & 9.6 & - & - \\
\hline & 15Mar94 & Outlet & 37 & 750 & 0.40 & 0.8 & - & - & - & 2,040 & 12 & - & - \\
\hline & 15Mar94 & Outlet & 42 & 750 & 0.60 & 0.8 & - & - & - & 1,964 & 13.3 & - & - \\
\hline & 16Mar94 & Outlet & 22 & 700 & 0.40 & 0.8 & - & - & - & - & - & 140 & - \\
\hline & 20Apr94 & Inlet & - & - & - & - & 310 & - & - & - & - & - & 2.4 \\
\hline & $20 \mathrm{Apr} 94$ & Outlet & 22 & 700 & 0.40 & 0.8 & 300 & - & - & - & - & - & 1.6 \\
\hline \multirow[t]{16}{*}{ G } & 15Apr94 & Outlet & 7 & 620 & 0.40 & 0.8 & - & - & 0.9 & - & - & - & - \\
\hline & 15Apr94 & Outlet & 12 & 620 & 0.60 & 0.8 & - & - & 1.3 & - & - & - & - \\
\hline & 19Apr94 & Outlet & 14 & 620 & 0.60 & 1.0 & - & - & 18.8 & - & - & - & - \\
\hline & 18Apr94 & Outlet & 22 & 700 & 0.40 & 0.8 & - & - & 0.9 & - & - & - & - \\
\hline & 19Apr94 & Outlet & 27 & 700 & 0.60 & 0.8 & - & - & 2.4 & - & - & - & - \\
\hline & 18Apr94 & Outlet & 42 & 750 & 0.60 & 0.8 & - & - & 2.3 & - & - & - & - \\
\hline & 22Mar94 & Outlet & 2 & 620 & 0.24 & 0.8 & - & - & - & 2,136 & 8.6 & - & - \\
\hline & 22Mar94 & Outlet & 17 & 700 & 0.24 & 0.8 & - & - & - & 2,129 & 26.1 & - & - \\
\hline & 23Mar94 & Outlet & 22 & 700 & 0.40 & 0.8 & - & - & - & 2,191 & 25.6 & - & - \\
\hline & 22Mar94 & Outlet & 27 & 700 & 0.60 & 0.8 & - & - & - & 2,162 & 23 & - & - \\
\hline & 21Mar94 & Outlet & 32 & 750 & 0.24 & 0.8 & - & - & - & 1,969 & 39.3 & - & - \\
\hline & 21Mar94 & Outlet & 37 & 750 & 0.40 & 0.8 & - & - & - & 2,013 & 27.5 & - & - \\
\hline & 21Mar94 & Outlet & 42 & 750 & 0.60 & 0.8 & - & - & - & 2,096 & 25.7 & - & - \\
\hline & 23Mar94 & Outlet & 22 & 700 & 0.40 & 0.8 & - & - & - & - & - & 157 & - \\
\hline & 20Apr94 & Inlet & - & - & - & - & 310 & - & - & - & - & - & 2.4 \\
\hline & 20Apr94 & Outlet & 22 & 700 & 0.40 & 0.8 & 319 & - & - & - & - & - & 1.6 \\
\hline
\end{tabular}

${ }^{2}$ Dash indicates that no tests were performed at these conditions. 
Table A-9. Parametric Test Data-Test Sequence 3

\begin{tabular}{|c|c|c|c|c|c|c|c|c|c|c|c|c|c|}
\hline \multirow[b]{2}{*}{ Reactor } & \multirow[b]{2}{*}{ Date } & \multirow[b]{2}{*}{ Location } & \multicolumn{4}{|c|}{ Target Reactor Operating Conditions } & \multirow{2}{*}{$\begin{array}{c}\text { Inlet } \\
\text { NOx, } \\
\text { wppmv } \\
\end{array}$} & \multirow{2}{*}{$\begin{array}{l}\text { Outlet } \\
\text { NOx, } \\
\text { wppmv }\end{array}$} & \multicolumn{5}{|c|}{ Average Concentration, dppmv @ $3 \% \mathrm{O}_{2}$} \\
\hline & & & $\begin{array}{c}\text { Test } \\
\text { Condition Code } \\
\end{array}$ & $\begin{array}{c}\text { Temp., } \\
{ }^{\circ} \mathbf{F}\end{array}$ & $\begin{array}{c}\text { Flue Gas, } \\
\text { kwscfm }\end{array}$ & $\mathrm{NH}_{3} / \mathrm{NOx}$ & & & $\mathrm{NH}_{3}$ & $\mathrm{SO}_{2}$ & $\mathrm{SO}_{3}$ & $\mathbf{H C l}$ & $\mathbf{N}_{2} \mathbf{O}$ \\
\hline \multirow[t]{19}{*}{ A } & 27Jun94 & Outlet & 2 & 620 & 3.0 & 0.8 & 383 & - & 2.3 & - & - & - & - \\
\hline & 29Jun94 & Outlet & 6 & 620 & 5.0 & 0.6 & 371 & 123 & 1.9 & - & - & - & - \\
\hline & 29Jun94 & Outlet & 7 & 620 & 5.0 & 0.8 & 362 & 58 & 2.3 & - & - & - & - \\
\hline & 08Aug94 & Outlet & 9 & 620 & 5.0 & 1.0 & 292 & 6 & 4.5 & - & - & - & - \\
\hline & 08Aug94 & Outlet & 14 & 620 & 6.2 & 1.0 & 214 & 3 & 5.3 & - & - & - & - \\
\hline & 24Jun94 & Outlet & 21 & 700 & 5.0 & 0.6 & 336 & - & 1.5 & - & - & - & - \\
\hline & 27Jun94 & Outlet & 22 & 700 & 5.0 & 0.8 & 363 & - & 2.5 & - & - & - & - \\
\hline & 10Aug94 & Outlet & 24 & 700 & 5.0 & 1.0 & 295 & 33 & 2.2 & - & - & - & - \\
\hline & 28Jun94 & Outlet & 26 & 700 & 6.0 & 0.6 & 360 & - & 2.1 & - & - & - & - \\
\hline & 28Jun94 & Outlet & 27 & 700 & 6.0 & 0.8 & 331 & - & 2.7 & - & - & - & - \\
\hline & 10Aug94 & Outlet & 29 & 700 & 6.0 & 1.0 & 330 & 32 & 3.0 & - & - & - & - \\
\hline & 09Aug94 & Outlet & 36 & 750 & 5.0 & 0.6 & 396 & 173 & 2.1 & - & - & - & - \\
\hline & 09Aug94 & Outlet & 37 & 750 & 5.0 & 0.8 & 390 & 85 & 2.0 & - & - & - & - \\
\hline & 11Aug94 & Outlet & 39 & 750 & 5.0 & 1.0 & 299 & 42 & 2.3 & - & - & - & - \\
\hline & 14Sep94 & Inlet & 22 & 700 & 5.0 & 0.8 & - & - & - & 2,218 & 0.4 & - & - \\
\hline & 14Sep94 & Outlet & 22 & 700 & 5.0 & 0.8 & - & - & - & 2,157 & 18 & - & - \\
\hline & 14Sep94 & Inlet & 37 & 750 & 5.0 & 0.8 & - & - & - & 2,176 & 0.2 & - & - \\
\hline & 14Sep94 & Outlet & 37 & 750 & 5.0 & 0.8 & - & - & - & 2,131 & 33.8 & - & - \\
\hline & 20Sep94 & Outlet & 22 & 700 & 5.0 & 0.8 & - & - & - & - & - & 233 & - \\
\hline \multirow[t]{7}{*}{$\mathrm{B}$} & 11Jul94 & Outlet & 2 & 620 & 3.0 & 0.8 & 339 & 46 & 1.6 & - & - & - & - \\
\hline & 11 Jul94 & Outlet & 6 & 620 & 5.0 & 0.6 & 321 & 109 & 1 & - & - & - & - \\
\hline & 12Jul94 & Outlet & 7 & 620 & 5.0 & 0.8 & 317 & 61 & $<1.0$ & - & - & - & - \\
\hline & 13Jul94 & Outlet & 9 & 620 & 5.0 & 1.0 & 347 & 3 & 3.5 & - & - & - & - \\
\hline & 26Aug94 & Outlet & 14 & 620 & 7.5 & 1.0 & 357 & 13 & 12.3 & - & - & - & - \\
\hline & 18Aug94 & Outlet & 21 & 700 & 5.0 & 0.6 & 358 & 134 & 1.2 & - & - & - & - \\
\hline & 13Jul94 & Outlet & 22 & 700 & 5.0 & 0.8 & 324 & 57 & 1.0 & - & - & - & - \\
\hline
\end{tabular}


Table A-9 (continued)

\begin{tabular}{|c|c|c|c|c|c|c|c|c|c|c|c|c|c|}
\hline \multirow[b]{2}{*}{ Reactor } & \multirow[b]{2}{*}{ Date } & \multirow[b]{2}{*}{ Location } & \multicolumn{4}{|c|}{ Target Reactor Operating Conditions } & \multirow{2}{*}{$\begin{array}{c}\text { Inlet } \\
\text { NOx, } \\
\text { wppmv }\end{array}$} & \multirow{2}{*}{$\begin{array}{c}\text { Outlet } \\
\text { NOx, } \\
\text { wppmv }\end{array}$} & \multicolumn{5}{|c|}{ Average Concentration, dppmv @ $3 \% \mathrm{O}_{2}$} \\
\hline & & & $\begin{array}{c}\text { Test } \\
\text { Condition Code } \\
\end{array}$ & \begin{tabular}{|c|} 
Temp., \\
${ }^{\circ} \mathbf{F}$
\end{tabular} & $\begin{array}{c}\text { Flue Gas, } \\
\text { kwscfm }\end{array}$ & $\mathrm{NH}_{3} / \mathrm{NOx}$ & & & $\mathrm{NH}_{3}$ & $\mathrm{SO}_{2}$ & $\mathrm{SO}_{3}$ & $\mathbf{H C l}$ & $\mathbf{N}_{2} \mathrm{O}$ \\
\hline \multirow[t]{12}{*}{ B } & 29Aug94 & Outlet & 24 & 700 & 5.0 & 1.0 & 344 & 0.3 & 3.6 & - & - & - & - \\
\hline & 12Aug94 & Outlet & 26 & 700 & 7.5 & 0.6 & 342 & 134 & 1.2 & - & - & - & - \\
\hline & 31 Aug94 & Outlet & 27 & 700 & 6.5 & 0.8 & 296 & 51 & 1.8 & - & - & - & - \\
\hline & 26Aug94 & Outlet & 29 & 700 & 7.5 & 1.0 & 337 & 7 & 5.4 & - & - & - & - \\
\hline & 11 Aug94 & Outlet & 36 & 750 & 5.0 & 0.6 & 284 & 70 & 1.2 & - & - & - & - \\
\hline & 09Aug94 & Outlet & 37 & 750 & 5.0 & 0.8 & 396 & 83 & 1.0 & - & - & - & - \\
\hline & 09Aug94 & Outlet & 39 & 750 & 5.0 & 1.0 & 387 & 14 & 2.0 & - & - & - & - \\
\hline & 16Sep94 & Inlet & 22 & 700 & 5.0 & 0.8 & - & - & - & 2,231 & 0.1 & - & - \\
\hline & 16Sep94 & Outlet & 22 & 700 & 5.0 & 0.8 & - & - & - & 2,131 & 4.9 & - & - \\
\hline & 16Sep94 & Inlet & 37 & 750 & 5.0 & 0.8 & - & - & - & 2,216 & 0.2 & - & - \\
\hline & 16Sep94 & Outlet & 37 & 750 & 5.0 & 0.8 & - & - & - & 2,127 & 7.2 & - & - \\
\hline & 19Sep94 & Outlet & 22 & 700 & 5.0 & 0.8 & - & - & - & - & - & 238 & - \\
\hline \multirow[t]{14}{*}{$\mathrm{C}$} & 28Jun94 & Outlet & 2 & 620 & 3.0 & 0.8 & 347 & - & 1.0 & - & - & - & - \\
\hline & 28Jun94 & Outlet & 6 & 620 & 5.0 & 0.6 & 359 & - & 1.4 & - & - & - & - \\
\hline & 29Jun94 & Outlet & 7 & 620 & 5.0 & 0.8 & 373 & 24 & 3.1 & - & - & - & - \\
\hline & 29Jun94 & Outlet & 9 & 620 & 5.0 & 1.0 & 365 & - & 25.3 & - & - & - & - \\
\hline & 15Ju194 & Outlet & 14 & 620 & 7.4 & 1.0 & 350 & 22 & 26.5 & - & - & - & - \\
\hline & 24Jun94 & Outlet & 21 & 700 & 5.0 & 0.6 & 333 & 107 & 1.2 & - & - & - & - \\
\hline & 12Jul94 & Outlet & 22 & 700 & 5.0 & 0.8 & 378 & 29 & 3.6 & - & - & - & - \\
\hline & $12 \mathrm{Jul} 94$ & Outlet & 24 & 700 & 5.0 & 1.0 & 318 & 6 & 18.6 & - & - & - & - \\
\hline & 13Jul94 & Outlet & 26 & 700 & 6.8 & 0.6 & 345 & 80 & 4.5 & - & - & - & - \\
\hline & 13Jul94 & Outlet & 27 & 700 & 6.8 & 0.8 & 323 & 31 & 8.5 & - & - & - & - \\
\hline & 27Jun94 & Outlet & 29 & 700 & 7.0 & 1.0 & 383 & & 19.1 & - & - & - & - \\
\hline & $11 \mathrm{Ju} 194$ & Outlet & 36 & 750 & 5.0 & 0.6 & 337 & 84 & 1.6 & - & - & - & - \\
\hline & 27Jun94 & Outlet & 37 & 750 & 5.0 & 0.8 & 359 & & 3.6 & - & - & - & - \\
\hline & 11Jul94 & Outlet & 39 & 750 & 5.0 & 1.0 & 321 & 5 & 11.3 & - & - & - & \\
\hline
\end{tabular}


Table A-9 (continued)

\begin{tabular}{|c|c|c|c|c|c|c|c|c|c|c|c|c|c|}
\hline \multirow[b]{2}{*}{ Reactor } & \multirow[b]{2}{*}{ Date } & \multirow[b]{2}{*}{ Location } & \multicolumn{4}{|c|}{ Target Reactor Operating Conditions } & \multirow{2}{*}{$\begin{array}{c}\text { Inlet } \\
\text { NOx, } \\
\text { wppmv }\end{array}$} & \multirow{2}{*}{$\begin{array}{l}\text { Outlet } \\
\text { NOx, } \\
\text { wppmv }\end{array}$} & \multicolumn{5}{|c|}{ Average Concentration, dppmv @ $3 \% \mathrm{O}_{2}$} \\
\hline & & & $\begin{array}{c}\text { Test } \\
\text { Condition Code } \\
\end{array}$ & \begin{tabular}{|} 
Temp., \\
${ }^{\circ} \mathbf{F}$
\end{tabular} & $\begin{array}{c}\text { Flue Gas, } \\
\text { kwscfm }\end{array}$ & $\mathrm{NH}_{3} / \mathrm{NOx}$ & & & $\mathrm{NH}_{3}$ & $\mathrm{SO}_{2}$ & $\mathrm{SO}_{3}$ & $\mathbf{H C l}$ & $\mathbf{N}_{2} \mathrm{O}$ \\
\hline \multirow[t]{5}{*}{$\mathrm{C}$} & 15Sep94 & Inlet & 22 & 700 & 5.0 & 0.8 & - & - & - & 2,165 & 0.2 & - & - \\
\hline & 15 Sep 94 & Outlet & 22 & 700 & 5.0 & 0.8 & - & - & - & 2,166 & 15.3 & - & - \\
\hline & 15Sep94 & Inlet & 37 & 750 & 5.0 & 0.8 & - & - & - & 2,155 & 0.2 & 一 & - \\
\hline & $15 \operatorname{Sep} 94$ & Outlet & 37 & 750 & 5.0 & 0.8 & - & - & - & 2,149 & 26.9 & - & - \\
\hline & $20 \operatorname{Sep} 94$ & Outlet & 22 & 700 & 5.0 & 0.8 & - & - & - & - & - & 233 & - \\
\hline \multirow[t]{21}{*}{ D } & 15Jul94 & Outlet & 2 & 620 & 0.24 & 0.8 & 350 & 7 & 10.1 & - & - & - & - \\
\hline & 26Aug94 & Outlet & 6 & 620 & 0.40 & 0.6 & 359 & 33 & 4.8 & - & - & - & - \\
\hline & 25Aug94 & Outlet & 7 & 620 & 0.40 & 0.8 & 336 & 6 & 15 & - & - & - & - \\
\hline & 29Aug94 & Outlet & 9 & 620 & 0.40 & 1.0 & 344 & 11 & 72.5 & - & - & - & - \\
\hline & 29Aug94 & Outlet & 14 & 620 & 0.60 & 1.0 & 338 & 17 & 73.9 & - & - & - & - \\
\hline & 19Aug94 & Outlet & 21 & 700 & 0.40 & 0.6 & 313 & 31 & 2.6 & - & - & - & - \\
\hline & 10Aug94 & Outlet & 22 & 700 & 0.40 & 0.8 & 294 & 6 & 6.6 & - & - & - & - \\
\hline & 10Aug94 & Outlet & 24 & 700 & 0.40 & 1.0 & 327 & 5 & 38.8 & - & - & - & - \\
\hline & 19Aug94 & Outlet & 26 & 700 & 0.60 & 0.6 & 358 & 52 & 7.4 & - & - & - & - \\
\hline & 09Sep94 & Outlet & 27 & 700 & 0.60 & 0.8 & 351 & 18 & 21.4 & - & - & - & - \\
\hline & 09Sep94 & Outlet & 29 & 700 & 0.60 & 1.0 & 346 & 14 & 57.4 & - & - & - & - \\
\hline & 12Sep94 & Outlet & 36 & 750 & 0.40 & 0.6 & 291 & 48 & 1.8 & - & - & - & - \\
\hline & 12Sep94 & Outlet & 37 & 750 & 0.40 & 0.8 & 282 & 30 & 3.5 & - & - & - & - \\
\hline & 13Sep94 & Outlet & 39 & 750 & 0.40 & 1.0 & 332 & 4 & 14.8 & - & - & - & - \\
\hline & 26Sep94 & Outlet & 2 & 620 & 0.40 & 0.8 & 364 & 11 & 4.5 & - & - & - & - \\
\hline & 26Sep94 & Outlet & 7 & 620 & 0.60 & 0.8 & 336 & 23 & 15.4 & - & - & - & - \\
\hline & 27Sep94 & Outlet & 22 & 700 & 0.40 & 0.8 & 370 & 34 & 4.7 & - & - & - & - \\
\hline & 19Sep94 & Inlet & 22 & 700 & 0.40 & 0.8 & - & - & - & 2,231 & 1.3 & - & - \\
\hline & 19Sep94 & Outlet & 22 & 700 & 0.40 & 0.8 & - & - & - & 2,274 & 8.9 & - & - \\
\hline & 19Sep94 & Inlet & 37 & 750 & 0.40 & 0.8 & - & - & - & 2,283 & 1.9 & - & - \\
\hline & 19Sep94 & Outlet & 37 & 750 & 0.40 & 0.8 & - & - & - & 2,183 & 25.1 & - & - \\
\hline
\end{tabular}


Table A-9 (continued)

\begin{tabular}{|c|c|c|c|c|c|c|c|c|c|c|c|c|c|}
\hline \multirow[b]{2}{*}{ Reactor } & \multirow[b]{2}{*}{ Date } & \multirow[b]{2}{*}{ Location } & \multicolumn{4}{|c|}{ Target Reactor Operating Conditions } & \multirow{2}{*}{$\begin{array}{c}\text { Inlet } \\
\text { NOx, } \\
\text { wppmv } \\
\end{array}$} & \multirow{2}{*}{$\begin{array}{c}\text { Outlet } \\
\text { NOx, } \\
\text { wppmv } \\
\end{array}$} & \multicolumn{5}{|c|}{ Average Concentration, dppmv @ $3 \% \mathrm{O}_{2}$} \\
\hline & & & $\begin{array}{c}\text { Test } \\
\text { Condition Code }\end{array}$ & \begin{tabular}{|c|} 
Temp., \\
${ }^{\circ} \mathbf{F}$
\end{tabular} & $\begin{array}{c}\text { Flue Gas, } \\
\text { kwscfm }\end{array}$ & $\mathrm{NH}_{3} / \mathrm{NOx}$ & & & $\mathbf{N H}_{3}$ & $\mathrm{SO}_{2}$ & $\mathrm{SO}_{3}$ & $\mathbf{H C l}$ & $\mathrm{N}_{2} \mathrm{O}$ \\
\hline $\mathrm{D}$ & 23Sep94 & Outlet & 22 & 700 & 0.40 & 0.8 & - & - & - & - & - & 232 & - \\
\hline \multirow[t]{19}{*}{$E$} & 30Aug94 & Outlet & 2 & 620 & 0.24 & 0.8 & 322 & 30 & $<0.8$ & - & - & - & - \\
\hline & 30Aug94 & Outlet & 6 & 620 & 0.40 & 0.6 & 313 & 99 & $<0.8$ & - & - & - & - \\
\hline & 31 Aug94 & Outlet & 7 & 620 & 0.40 & 0.8 & 312 & 72 & $<0.7$ & - & - & - & - \\
\hline & 31 Aug94 & Outlet & 9 & 620 & 0.40 & 1.0 & 314 & 37 & $<0.7$ & - & - & - & - \\
\hline & 02Sep 94 & Outlet & 14 & 620 & 0.60 & 1.0 & 325 & 39 & 26.8 & - & - & - & - \\
\hline & 24Aug94 & Outlet & 21 & 700 & 0.40 & 0.6 & 348 & 69 & $<1.1$ & - & - & - & - \\
\hline & 23Aug94 & Outlet & 22 & 700 & 0.40 & 0.8 & 339 & 23 & $<0.9$ & - & - & - & - \\
\hline & 25Aug94 & Outlet & 24 & 700 & 0.40 & 1.0 & 311 & 2 & 2.4 & - & - & - & - \\
\hline & 29Aug94 & Outlet & 26 & 700 & 0.60 & 0.6 & 346 & 81 & $<0.8$ & - & - & - & - \\
\hline & 26Aug94 & Outlet & 27 & 700 & 0.60 & 0.8 & 358 & 26 & 1.2 & - & - & - & - \\
\hline & 25Aug94 & Outlet & $\therefore \quad 29$ & 700 & 0.60 & 1.0 & 344 & 3 & 11.4 & - & - & - & - \\
\hline & 14Sep94 & Outlet & 36 & 750 & 0.40 & 0.6 & 323 & 98 & $<0.6$ & - & - & - & - \\
\hline & 14Sep94 & Outlet & 37 & 750 & 0.40 & 0.8 & 317 & 67 & 0.6 & - & - & - & - \\
\hline & 01Sep94 & Outlet & 39 & 750 & 0.40 & 1.0 & 334 & 30 & $<0.8$ & - & - & - & - \\
\hline & 20Sep94 & Inlet & 22 & 700 & 0.40 & 0.8 & - & - & - & 2,299 & 1.5 & - & - \\
\hline & 20Sep94 & Outlet & 22 & 700 & 0.40 & 0.8 & - & - & - & 2,303 & 9.5 & - & - \\
\hline & $20 \operatorname{Sep} 94$ & Inlet & 37 & 750 & 0.40 & 0.8 & - & - & - & 2,315 & 0.4 & - & - \\
\hline & 20Sep94 & Outlet & 37 & 750 & 0.40 & 0.8 & - & - & - & 2,276 & 15 & - & - \\
\hline & 23Sep94 & Outlet & 22 & 700 & 0.40 & 0.8 & - & - & - & - & - & 226 & - \\
\hline \multirow[t]{6}{*}{$\mathrm{F}$} & 15Jul94 & Outlet & 2 & 620 & 0.24 & 0.8 & 352 & 25 & 1.7 & - & - & - & - \\
\hline & 02Sep94 & Outlet & 6 & 620 & 0.40 & 0.6 & 318 & 68 & 0.9 & - & - & - & - \\
\hline & 02Sep94 & Outlet & 7 & 620 & 0.40 & 0.8 & 311 & 18 & 3.2 & - & - & - & - \\
\hline & 22Aug94 & Outlet & 9 & 620 & 0.40 & 1.0 & 330 & 3 & 78.7 & - & - & - & - \\
\hline & $23 \mathrm{Aug} 94$ & Outlet & 14 & 620 & 0.60 & 1.0 & 348 & 11 & 90.1 & - & - & - & - \\
\hline & 18Aug94 & Outlet & 21 & 700 & 0.40 & 0.6 & 359 & 57 & 2.2 & - & - & - & - \\
\hline
\end{tabular}


Table A-9 (continued)

\begin{tabular}{|c|c|c|c|c|c|c|c|c|c|c|c|c|c|}
\hline \multirow[b]{2}{*}{ Reactor } & \multirow[b]{2}{*}{ Date } & \multirow[b]{2}{*}{ Location } & \multicolumn{4}{|c|}{ Target Reactor Operating Conditions } & \multirow{2}{*}{$\begin{array}{c}\text { Inlet } \\
\text { NOx, } \\
\text { wppmv }\end{array}$} & \multirow{2}{*}{$\begin{array}{c}\text { Outlet } \\
\text { NOx, } \\
\text { wppmv }\end{array}$} & \multicolumn{5}{|c|}{ Average Concentration,dppmv@3\% $\mathrm{O}_{2}$} \\
\hline & & & $\begin{array}{c}\text { Test } \\
\text { Condition Code } \\
\end{array}$ & $\begin{array}{c}\text { Temp., } \\
{ }^{\circ} \mathrm{F}\end{array}$ & $\begin{array}{c}\text { Flue Gas, } \\
\text { kwscfm }\end{array}$ & $\mathrm{NH}_{3} / \mathrm{NOx}$ & & & $\mathrm{NH}_{3}$ & $\mathrm{SO}_{2}$ & $\mathrm{SO}_{3}$ & $\mathbf{H C l}$ & $\mathrm{N}_{2} \mathrm{O}$ \\
\hline \multirow[t]{16}{*}{ F } & 01Sep94 & Outlet & 22 & 700 & 0.40 & 0.8 & 327 & 52 & 1.0 & - & - & - & - \\
\hline & 01Sep94 & Outlet & 24 & $700^{\circ}$ & 0.40 & 1.0 & 350 & 2 & 17.3 & - & - & - & - \\
\hline & 19Aug94 & Outlet & 26 & 700 & 0.60 & 0.6 & 315 & 64 & 3.8 & - & - & - & - \\
\hline & 13Sep94 & Outlet & 27 & 700 & 0.60 & 0.8 & 336 & 34 & 9.3 & - & - & - & - \\
\hline & 13Sep94 & Outlet & 29 & 700 & 0.60 & 1.0 & 329 & 11 & 56.5 & - & - & - & - \\
\hline & 18Aug94 & Outlet & 36 & 750 & 0.40 & 0.6 & 357 & 80 & 2.8 & - & - & - & - \\
\hline & 12Aug94 & Outlet & 37 & 750 & 0.40 & 58.0 & 252 & 11 & 3.1 & - & - & - & - \\
\hline & 12Aug94 & Outlet & 39 & 750 & 0.40 & 1.0 & 341 & 1 & 52.7 & - & - & - & - \\
\hline & 24Aug94 & Outlet & 2 & 620 & 0.24 & 0.8 & 342 & 0 & 41.1 & - & - & - & - \\
\hline & 19Aug94 & Outlet & 21 & 700 & 0.40 & 0.6 & 359 & 67 & $<0.9$ & - & - & - & - \\
\hline & 12Sep94 & Outlet & 39 & 750 & 0.40 & 1 & 287 & 2 & 18.4 & - & - & - & - \\
\hline & 21Sep94 & Inlet & 22 & 700 & 0.40 & 0.8 & - & - & - & 2,160 & 0.2 & - & - \\
\hline & 21Sep94 & Outlet & 22 & 700 & 0.40 & 0.8 & - & - & - & 2,187 & 1.7 & - & - \\
\hline & 21Sep94 & Inlet & 37 & 750 & 0.40 & 0.8 & - & - & - & 2,167 & 1.0 & - & - \\
\hline & 21Sep94 & Outlet & 37 & 750 & 0.40 & 0.8 & - & - & - & 2,168 & 3.4 & - & - \\
\hline & 20Sep94 & Outlet & 22 & 700 & 0.40 & 0.8 & - & - & - & - & - & 241 & - \\
\hline \multirow[t]{10}{*}{$\mathrm{G}$} & 23Aug94 & Outlet & 2 & 620 & 0.24 & 0.8 & 347 & 17 & $<1.0$ & - & - & - & - \\
\hline & 23Aug94 & Outlet & 6 & 620 & 0.40 & 0.6 & 349 & 81 & $<0.9$ & - & - & - & - \\
\hline & 24Aug94 & Outlet & 7 & 620 & 0.40 & 0.8 & 342 & 14 & 2.2 & - & - & - & - \\
\hline & 08Sep94 & Outlet & 9 & 620 & 0.40 & 1.0 & 367 & 0 & 94.1 & - & - & - & - \\
\hline & 14Sep94 & Outlet & 14 & 620 & 0.60 & 1.0 & 312 & 21 & 43.8 & - & - & - & - \\
\hline & 09Sep94 & Outlet & 21 & 700 & 0.40 & 0.6 & 352 & 78 & 0.8 & - & - & - & - \\
\hline & 09Sep94 & Outlet & 22 & 700 & 0.40 & 0.8 & 348 & 19 & 2.2 & - & - & - & - \\
\hline & 19Aug94 & Outlet & 24 & 700 & 0.40 & 1.0 & 358 & 1 & 57.3 & - & - & - & - \\
\hline & 12Sep94 & Outlet & 26 & 700 & 0.60 & 0.6 & 289 & 107 & 1.3 & 二 & - & - & - \\
\hline & 12Sep94 & Outlet & 27 & 700 & 0.60 & 0.8 & 281 & 62 & 3.1 & - & - & - & - \\
\hline
\end{tabular}


Table A-9 (continued)

\begin{tabular}{|c|c|c|c|c|c|c|c|c|c|c|c|c|c|}
\hline \multirow[b]{2}{*}{ Reactor } & \multirow[b]{2}{*}{ Date } & \multirow[b]{2}{*}{ Location } & \multicolumn{4}{|c|}{ Target Reactor Operating Conditions } & \multirow{2}{*}{$\begin{array}{c}\text { Inlet } \\
\text { NOx, } \\
\text { wppmv }\end{array}$} & \multirow{2}{*}{$\begin{array}{c}\text { Outlet } \\
\text { NOx, } \\
\text { wppmv }\end{array}$} & \multicolumn{5}{|c|}{ Average Concentration, dppmv @ $3 \% \mathrm{O}_{2}$} \\
\hline & & & $\begin{array}{c}\text { Test } \\
\text { Condition Code } \\
\end{array}$ & $\begin{array}{c}\text { Temp., } \\
{ }^{\circ} \mathbf{F}\end{array}$ & $\begin{array}{c}\text { Flue Gas, } \\
\text { kwscfm }\end{array}$ & $\mathrm{NH}_{3} / \mathrm{NOx}$ & & & $\mathbf{N H}_{3}$ & $\mathrm{SO}_{2}$ & $\mathrm{SO}_{3}$ & $\mathbf{H C l}$ & $\mathbf{N}_{\mathbf{2}} \mathrm{O}$ \\
\hline \multirow[t]{9}{*}{$\mathrm{G}$} & 19Aug94 & Outlet & 29 & 700 & 0.60 & 1.0 & 314 & 3 & 41.6 & - & - & - & - \\
\hline & 13Sep94 & Outlet & 36 & 750 & 0.40 & 0.6 & 336 & 102 & 1.3 & - & - & - & - \\
\hline & 13Sep94 & Outlet & 37 & 750 & 0.40 & 0.8 & 328 & 72 & 2.2 & - & - & - & - \\
\hline & 22Aug94 & Outlet & 39 & 750 & 0.40 & 1.0 & 331 & 8 & 32.7 & - & - & - & - \\
\hline & 22Sep94 & Inlet & 22 & 700 & 0.40 & 0.8 & - & - & - & 2,286 & 0.5 & - & - \\
\hline & 22Sep94 & Outlet & 22 & 700 & 0.40 & 0.8 & $\ldots$ & - & - & 2,172 & 2.2 & - & - \\
\hline & 22Sep94 & Inlet & 37 & 750 & 0.40 & 0.8 & - & - & - & 2,197 & 0.4 & - & - \\
\hline & 22Sep94 & Outlet & 37 & 750 & 0.40 & 0.8 & - & - & - & 1,948 & 17.1 & - & - \\
\hline & 21Sep94 & Outlet & 22 & 700 & 0.40 & 0.8 & - & - & - & - & - & 225 & - \\
\hline \multirow[t]{14}{*}{$\mathrm{J}$} & 24Aug94 & Outlet & 2 & 620 & 0.24 & 0.8 & 307 & 119 & 1.2 & - & - & - & - \\
\hline & 25Aug94 & Outlet & 6 & 620 & 0.40 & 0.6 & 323 & 144 & 1.9 & - & - & - & - \\
\hline & 25Aug94 & Outlet & 7 & 620 & 0.40 & 0.8 & 304 & 109 & 3.0 & - & - & - & - \\
\hline & 26Aug94 & Outlet & 9 & 620 & 0.40 & 1.0 & 331 & 84 & 5.1 & - & - & - & - \\
\hline & 26Aug94 & Outlet & 14 & 620 & 0.60 & 1.0 & 321 & 87 & 21.8 & - & - & - & - \\
\hline & 30Aug94 & Outlet & 21 & 700 & 0.40 & 0.6 & 299 & 126 & 0.8 & - & - & - & - \\
\hline & 01Sep94 & Outlet & 22 & 700 & 0.40 & 0.8 & 306 & 109 & 1.3 & - & - & - & - \\
\hline & 01Sep94 & Outlet & 24 & 700 & 0.40 & 1.0 & 321 & 16 & 4.1 & - & - & - & - \\
\hline & 30Aug94 & Outlet & 26 & 700 & 0.60 & 0.6 & 300 & 122 & 2.0 & - & - & - & - \\
\hline & 31 Aug94 & Outlet & 27 & 700 & 0.60 & 0.8 & 293 & 73 & 3.9 & - & - & 二 & - \\
\hline & 31 Aug94 & Outlet & 29 & 700 & 0.60 & 1.0 & 292 & 31 & 8.9 & - & - & - & - \\
\hline & 23Sep94 & Inlet & 22 & 700 & 0.40 & 0.8 & - & - & - & 2,160 & 0.5 & - & - \\
\hline & 23Sep 94 & Outlet & 22 & 700 & 0.40 & 0.8 & - & - & - & 2,376 & 9.1 & - & - \\
\hline & $21 \mathrm{Sep} 94$ & Outlet & 22 & 700 & 0.40 & 0.8 & $=$ & $=$ & - & - & $=$ & 234 & $=$ \\
\hline
\end{tabular}

a Dash indicates that no tests were performed at these conditions. 
Table A-10. Parametric Test Data-Test Sequence 4

\begin{tabular}{|c|c|c|c|c|c|c|c|c|c|c|c|c|c|}
\hline \multirow[b]{2}{*}{ Reactor } & \multirow[b]{2}{*}{ Date } & \multirow[b]{2}{*}{ Location } & \multicolumn{4}{|c|}{ Target Reactor Operating Conditions } & \multirow{2}{*}{$\begin{array}{c}\begin{array}{c}\text { Inlet } \\
\text { NOx, } \\
\text { wppmv }\end{array} \\
\end{array}$} & \multirow{2}{*}{$\begin{array}{c}\text { Outlet } \\
\text { NOx, } \\
\text { wppmv }\end{array}$} & \multicolumn{5}{|c|}{ Average Concentration, dppmv @3\% 0} \\
\hline & & & $\begin{array}{c}\text { Test } \\
\text { Condition Code } \\
\end{array}$ & $\begin{array}{c}\text { Temp., } \\
{ }^{\circ} \mathbf{F}\end{array}$ & $\begin{array}{c}\text { Flue Gas, } \\
\text { kwscfm }\end{array}$ & $\mathbf{N H}_{3} / \mathrm{NOx}$ & & & $\mathbf{N H}_{\mathbf{3}}$ & $\mathrm{SO}_{2}$ & $\mathrm{SO}_{3}$ & $\mathbf{H C l}$ & $\mathrm{N}_{2} \mathrm{O}$ \\
\hline \multirow[t]{24}{*}{ A } & $250 \mathrm{ct} 94$ & Outlet & 2 & 620 & 3.0 & 0.8 & 289 & 44 & 2.1 & $-{ }^{\mathrm{a}}$ & - & - & - \\
\hline & $270 c t 94$ & Outlet & 6 & 620 & 5.0 & 0.6 & 378 & 73 & 3.0 & - & - & - & - \\
\hline & $270 \mathrm{ct} 94$ & Outlet & 7 & 620 & 5.0 & 0.8 & 360 & 50 & 4.9 & - & - & - & - \\
\hline & 01 Nov94 & Outlet & 9 & 620 & 5.0 & 1.0 & 377 & 38 & 25.0 & - & - & - & - \\
\hline & $250 c t 94$ & Outlet & 14 & 620 & 6.8 & 1.0 & 302 & 38 & 7.2 & - & - & - & - \\
\hline & $280 c t 94$ & Outlet & 21 & 700 & 5.0 & 0.6 & 376 & 71 & 2.8 & - & - & - & - \\
\hline & $240 c t 94$ & Outlet & 22 & 700 & 5.0 & 0.8 & 268 & 64 & 3.3 & - & - & - & - \\
\hline & $280 \mathrm{ct} 94$ & Outlet & 24 & 700 & 5.0 & 1.0 & 365 & 63 & 2.8 & - & - & - & - \\
\hline & $260 \mathrm{ct} 94$ & Outlet & 26 & 700 & 6.4 & 0.6 & 343 & 100 & 3.3 & - & - & - & - \\
\hline & $240 \mathrm{ct} 94$ & Outlet & 27 & 700 & 6.0 & 0.8 & 263 & 64 & 3.0 & - & - & - & - \\
\hline & $260 \mathrm{ct} 94$ & Outlet & 29 & 700 & 6.4 & 1.0 & 320 & 13 & 10.2 & 一 & - & - & - \\
\hline & $310 c t 94$ & Outlet & 36 & 750 & 5.0 & 0.6 & 357 & 105 & 2.1 & - & - & - & - \\
\hline & $310 c t 94$ & Outlet & 37 & 750 & 5.0 & 0.8 & 313 & 39 & 3.1 & - & - & - & - \\
\hline & 02Nov94 & Outlet & 39 & 750 & 5.0 & 1.0 & 337 & 8 & 8.3 & - & - & - & - \\
\hline & 01Dec94 & Inlet & 22 & 700 & 5.0 & 0.8 & - & - & - & 1,913 & 10.0 & - & - \\
\hline & 01Dec94 & Outlet & 22 & 700 & 5.0 & 0.8 & - & - & - & 1,825 & 20.0 & - & - \\
\hline & 12Jan 95 & Inlet & 27 & 700 & 6.4 & 0.8 & - & - & - & 1,857 & 5.0 & - & - \\
\hline & $12 \operatorname{Jan} 95$ & Outlet & 27 & 700 & 6.4 & 0.8 & - & - & - & 1,799 & 16.6 & - & - \\
\hline & 01 Dec 94 & Inlet & 37 & 750 & 5.0 & 0.8 & - & - & - & 1,894 & 10.6 & - & - \\
\hline & 01 Dec94 & Outlet & 37 & 750 & 5.0 & 0.8 & - & - & - & 1,860 & 45.3 & - & - \\
\hline & 01Dec94 & Inlet & 22 & 700 & 5.0 & 0.8 & - & - & - & - & - & 139 & - \\
\hline & $01 \mathrm{Dec} 94$ & Outlet & 22 & 700 & 5.0 & 0.8 & - & - & - & - & - & 219 & - \\
\hline & 04Jan94 & Inlet & 22 & 700 & 5.0 & 0.8 & 一 & - & - & - & - & - & 1.2 \\
\hline & 04Jan94 & Outlet & 22 & 700 & 5.0 & 0.8 & - & - & - & - & - & - & 1.3 \\
\hline
\end{tabular}


Table A-10 (continued)

\begin{tabular}{|c|c|c|c|c|c|c|c|c|c|c|c|c|c|}
\hline \multirow[b]{2}{*}{ Reactor } & \multirow[b]{2}{*}{ Date } & \multirow[b]{2}{*}{ Location } & \multicolumn{4}{|c|}{ Target Reactor Operating Conditions } & \multirow{2}{*}{$\begin{array}{c}\text { Inlet } \\
\text { NOx, } \\
\text { wppmv }\end{array}$} & \multirow{2}{*}{$\begin{array}{l}\text { Outlet } \\
\text { NOx, } \\
\text { wppmv }\end{array}$} & \multicolumn{5}{|c|}{ Average Concentration, dppmv @ 3\% O } \\
\hline & & & $\begin{array}{c}\text { Test } \\
\text { Condition Code }\end{array}$ & $\underset{{ }^{\circ} \mathbf{F}}{\text { Temp., }}$ & $\begin{array}{c}\text { Flue Gas, } \\
\text { kwsefm }\end{array}$ & $\mathrm{NH}_{3} / \mathrm{NOx}$ & & & $\mathrm{NH}_{3}$ & $\mathrm{SO}_{2}$ & $\mathrm{SO}_{3}$ & $\mathbf{H C l}$ & $\mathrm{N}_{2} \mathrm{O}$ \\
\hline \multirow[t]{24}{*}{ B } & $250 c t 94$ & Outlet & 2 & 620 & 3.0 & 0.8 & 303 & 61 & 1.1 & - & - & - & - \\
\hline & $260 \mathrm{ct} 94$ & Outlet & 6 & 620 & 5.0 & 0.6 & 328 & 98 & $<0.7$ & - & - & - & - \\
\hline & 27 Oct94 & Outlet & 7 & 620 & 5.0 & 0.8 & 374 & 18 & 1.6 & - & - & - & - \\
\hline & $270 c t 94$ & Outlet & 9 & 620 & 5.0 & 1.0 & 361 & 3 & 11.5 & - & - & - & - \\
\hline & 01Nov94 & Outlet & 14 & 620 & 7.3 & 1.0 & 383 & 8 & 25.9 & - & - & - & - \\
\hline & 03Nov94 & Outlet & 21 & 700 & 5.0 & 0.6 & 335 & 108 & $<1.1$ & - & - & - & - \\
\hline & 260ct94 & Outlet & 22 & 700 & 5.0 & 0.8 & 305 & 37 & 1.2 & - & - & - & - \\
\hline & $280 c t 94$ & Outlet & 24 & 700 & 5.0 & 1.0 & 376 & 0 & 11.2 & - & - & - & - \\
\hline & $280 c t 94$ & Outlet & 26 & 700 & 7.5 & 0.6 & 377 & 100 & 1.5 & - & - & - & - \\
\hline & $240 c t 94$ & Outlet & 27 & 700 & 6.8 & 0.8 & 266 & 85 & 2.3 & - & - & - & - \\
\hline & 31 Oct94 & Outlet & 29 & 700 & 6.6 & 1.0 & 338 & 6 & 6.7 & - & - & - & - \\
\hline & 31 Oct 94 & Outlet & 36 & 750 & 5.0 & 0.6 & 334 & 109 & 1.1 & - & - & - & - \\
\hline & 02Nov94 & Outlet & 37 & 750 & 5.0 & 0.8 & 339 & 42 & 1.2 & - & - & - & - \\
\hline & 02Nov94 & Outlet & 39 & 750 & 5.0 & 1.0 & 322 & 9 & 2.3 & - & - & - & - \\
\hline & 30Nov94 & Inlet & 22 & 700 & 5.0 & 0.8 & - & - & - & 2,161 & 6.6 & - & - \\
\hline & 30Nov94 & Outlet & 22 & 700 & 5.0 & 0.8 & - & - & - & 2,112 & 4.6 & - & - \\
\hline & 12Jan95 & Inlet & 27 & 700 & 6.3 & 0.8 & - & - & - & 1,821 & 2.0 & - & - \\
\hline & 12Jan 95 & Outlet & 27 & 700 & 6.3 & 0.8 & - & - & - & 1,787 & 2.9 & - & - \\
\hline & 30Nov94 & Inlet & 37 & 750 & 5.0 & 0.8 & - & - & - & 1,934 & 9.7 & - & - \\
\hline & 30Nov94 & Outlet & 37 & 750 & 5.0 & 0.8 & - & - & - & 2,013 & 18.9 & - & - \\
\hline & 30Nov94 & Inlet & 22 & 700 & 5.0 & 0.8 & - & - & - & - & - & 161 & - \\
\hline & 30Nov94 & Outlet & 22 & 700 & 5.0 & 0.8 & - & - & - & - & - & 222 & - \\
\hline & 04Jan95 & Inlet & 22 & 700 & 5.0 & 0.8 & 361 & - & - & - & - & - & 1.2 \\
\hline & 04Jan95 & Outlet & 22 & 700 & 5.0 & 0.8 & 365 & - & - & - & - & - & 1.3 \\
\hline
\end{tabular}


Table A-10 (continued)

\begin{tabular}{|c|c|c|c|c|c|c|c|c|c|c|c|c|c|}
\hline \multirow[b]{2}{*}{ Reactor } & \multirow[b]{2}{*}{ Date } & \multirow[b]{2}{*}{ Location } & \multicolumn{4}{|c|}{ Target Reactor Operating Conditions } & \multirow{2}{*}{$\begin{array}{c}\text { Inlet } \\
\text { NOx, } \\
\text { wppmv }\end{array}$} & \multirow{2}{*}{$\begin{array}{l}\text { Outlet } \\
\text { NOx, } \\
\text { wppmv }\end{array}$} & \multicolumn{5}{|c|}{ Average Concentration, dppmv @ $3 \% \mathrm{O}_{2}$} \\
\hline & & & $\begin{array}{c}\text { Test } \\
\text { Condition Code } \\
\end{array}$ & $\begin{array}{c}\text { Temp., } \\
{ }^{\circ} \mathbf{F}\end{array}$ & $\begin{array}{c}\text { Flue Gas, } \\
\text { kwscfm }\end{array}$ & $\mathrm{NH}_{3} / \mathrm{NOx}$ & & & $\mathrm{NH}_{3}$ & $\mathrm{SO}_{2}$ & $\mathrm{SO}_{3}$ & $\mathbf{H C l}$ & $\mathbf{N}_{2} \mathbf{O}$ \\
\hline \multirow[t]{24}{*}{$\mathrm{C}$} & $280 \mathrm{ct} 94$ & Outlet & 2 & 620 & 3.0 & 0.8 & 377 & 3 & 2.7 & - & - & - & - \\
\hline & $280 c t 94$ & Outlet & 6 & 620 & 5.0 & 0.6 & 376 & 59 & 2.8 & - & - & - & - \\
\hline & $310 \mathrm{ct} 94$ & Outlet & 7 & 620 & 5.0 & 0.8 & 358 & 13 & 7.1 & - & - & - & - \\
\hline & $310 c t 94$ & Outlet & 9 & 620 & 5.0 & 1.0 & 330 & 2 & 42.2 & - & - & - & - \\
\hline & 09Nov94 & Outlet & 14 & 620 & 6.5 & 1.0 & 361 & & 45.6 & - & - & - & - \\
\hline & 01Nov94 & Outlet & 21 & 700 & 5.0 & 0.6 & 379 & 95 & 3.3 & - & - & - & - \\
\hline & 02Nov94 & Outlet & 22 & 700 & 5.0 & 0.8 & 346 & 45 & 5.7 & - & - & - & - \\
\hline & 02Nov94 & Outlet & 24 & 700 & 5.0 & 1.0 & 307 & 6 & 17 & - & - & - & - \\
\hline & 03Nov94 & Outlet & 26 & 700 & 6.4 & 0.6 & 336 & 129 & 5.1 & - & - & - & - \\
\hline & 03Nov94 & Outlet & 27 & 700 & 6.4 & 0.8 & 326 & 34 & 9.4 & - & - & - & - \\
\hline & 08Nov94 & Outlet & 29 & 700 & 6.3 & 1.0 & 373 & 0 & 22 & - & - & - & - \\
\hline & 08Nov94 & Outlet & 36 & 750 & 5.0 & 0.6 & 362 & & 2.8 & - & - & - & - \\
\hline & 04Nov94 & Outlet & 37 & 750 & 5.0 & 0.8 & 326 & 4 & 4.8 & - & - & - & - \\
\hline & 04Nov94 & Outlet & 39 & 750 & 5.0 & 1.0 & 339 & 11 & 17.7 & - & - & - & - \\
\hline & 28 Nov94 & Inlet & 22 & 700 & 5.0 & 0.8 & - & - & - & 2,101 & 9.6 & - & - \\
\hline & 28Nov94 & Outlet & 22 & 700 & 5.0 & 0.8 & - & - & - & 2,181 & 14.1 & - & - \\
\hline & 16Jan95 & Inlet & 27 & 700 & 6.0 & 0.8 & - & - & - & 1,864 & 6.0 & - & - \\
\hline & $16 \mathrm{Jan} 95$ & $\overline{\text { Outlet }}$ & 27 & 700 & 6.0 & 0.8 & - & - & - & 1,791 & 2.7 & - & - \\
\hline & 28 Nov94 & Inlet & 37 & 750 & 5.0 & 0.8 & - & - & - & 2,127 & 11.9 & - & - \\
\hline & 28Nov94 & Outlet & 37 & 750 & 5.0 & 0.8 & - & - & - & 2,152 & 40.9 & - & - \\
\hline & 28Nov94 & Inlet & 22 & 700 & 5.0 & 0.8 & - & - & - & - & - & 195 & - \\
\hline & 28Nov94 & Outlet & 22 & 700 & 5.0 & 0.8 & - & - & - & - & - & 260 & - \\
\hline & 05Jan95 & Inlet & - & - & - & - & 345 & - & - & - & - & - & 1.2 \\
\hline & 05Jan95 & Outlet & 22 & 700 & 5.0 & 0.8 & 349 & 50 & - & - & - & - & 2.0 \\
\hline
\end{tabular}


Table A-10 (continued)

\begin{tabular}{|c|c|c|c|c|c|c|c|c|c|c|c|c|c|}
\hline \multirow[b]{2}{*}{ Reactor } & \multirow[b]{2}{*}{ Date } & \multirow[b]{2}{*}{ Location } & \multicolumn{4}{|c|}{ Target Reactor Operating Conditions } & \multirow{2}{*}{$\begin{array}{c}\text { Inlet } \\
\text { NOx, } \\
\text { wppmv }\end{array}$} & \multirow{2}{*}{$\begin{array}{c}\text { Outlet } \\
\text { NOx, } \\
\text { wppmv }\end{array}$} & \multicolumn{5}{|c|}{ Average Concentration, dppmv @ 3\% O } \\
\hline & & & $\begin{array}{c}\text { Test } \\
\text { Condition Code }\end{array}$ & $\begin{array}{c}\text { Temp., } \\
{ }^{\circ} \mathbf{F}\end{array}$ & $\begin{array}{c}\text { Flue Gas, } \\
\text { kwscfm }\end{array}$ & $\mathrm{NH}_{3} / \mathrm{NOx}$ & & & $\mathrm{NH}_{3}$ & $\mathrm{SO}_{2}$ & $\mathrm{SO}_{3}$ & $\mathrm{HCl}$ & $\mathrm{N}_{2} \mathrm{O}$ \\
\hline \multirow[t]{24}{*}{$\mathrm{D}$} & 04Jan95 & Outlet & 2 & 620 & 0.24 & 0.8 & 353 & 16 & 5.8 & 一 & - & - & 一 \\
\hline & 04Jan95 & Outlet & 6 & 620 & 0.40 & 0.6 & 350 & 60 & 8.5 & - & - & - & - \\
\hline & 04Jan95 & Outlet & 7 & 620 & 0.40 & 0.8 & 359 & 42 & 24.4 & - & - & - & - \\
\hline & $11 \operatorname{Jan} 95$ & Outlet & 9 & 620 & 0.40 & 1.0 & 361 & 26 & 78.8 & - & - & - & - \\
\hline & 11Jan95 & Outlet & 14 & 620 & 0.60 & 1.0 & 384 & 60 & 94.1 & - & - & - & - \\
\hline & 05Jan95 & Outlet & 21 & 700 & 0.40 & 0.6 & 345 & 79 & 2.2 & - & - & - & - \\
\hline & 05Jan95 & Outlet & 22 & 700 & 0.40 & 0.8 & 345 & 23 & 7.5 & - & - & - & - \\
\hline & 05Jan95 & Outlet & 24 & 700 & 0.40 & 1.0 & 345 & 14 & 30.5 & - & - & - & - \\
\hline & 09Jan95 & Outlet & 26 & 700 & 0.60 & 0.6 & 343 & 58 & 3.2 & - & - & - & - \\
\hline & 09Jan95 & Outlet & 27 & 700 & 0.60 & 0.8 & 345 & 18 & 10.4 & - & - & - & - \\
\hline & 09Jan95 & Outlet & 29 & 700 & 0.60 & 1.0 & 338 & 9 & 40.1 & - & - & - & - \\
\hline & 10Jan95 & Outlet & 36 & 750 & 0.40 & 0.6 & 357 & 63 & 2.9 & - & - & - & - \\
\hline & 10Jan95 & Outlet & 37 & 750 & 0.40 & 0.8 & 356 & 26 & 7.2 & - & - & - & - \\
\hline & 10Jan95 & Outlet & 39 & 750 & 0.40 & 1.0 & 351 & 8 & 29.9 & - & - & - & - \\
\hline & 05Dec94 & Inlet & 22 & 700 & 0.40 & 0.8 & - & - & - & 1,813 & 4.9 & - & - \\
\hline & 05Dec94 & Outlet & 22 & 700 & 0.40 & 0.8 & - & - & - & 1,839 & 14.6 & - & - \\
\hline & $17 \operatorname{Jan} 95$ & Inlet & 27 & 700 & 0.60 & 0.8 & - & - & - & 1,801 & 0.8 & - & - \\
\hline & $17 \mathrm{Jan} 95$ & Outlet & 27 & 700 & 0.60 & 0.8 & - & - & - & 1,726 & 0.2 & - & - \\
\hline & 06Dec94 & Inlet & 37 & 750 & 0.40 & 0.8 & - & - & - & 1,829 & 1.2 & - & - \\
\hline & $06 \mathrm{Dec} 94$ & Outlet & 37 & 750 & 0.40 & 0.8 & - & - & - & 1,834 & 12.0 & - & - \\
\hline & $05 \mathrm{Dec} 94$ & Inlet & 22 & 700 & 0.40 & 0.8 & - & - & - & - & - & 164 & - \\
\hline & $05 \mathrm{Dec} 94$ & Outlet & 22 & 700 & 0.40 & 0.8 & - & - & - & - & - & 223 & - \\
\hline & 05Jan95 & Inlet & - & - & - & - & 345 & - & - & - & - & - & 1.2 \\
\hline & 05Jan95 & Outlet & 22 & 700 & 0.40 & 0.8 & 345 & - & - & - & - & - & 2.0 \\
\hline
\end{tabular}




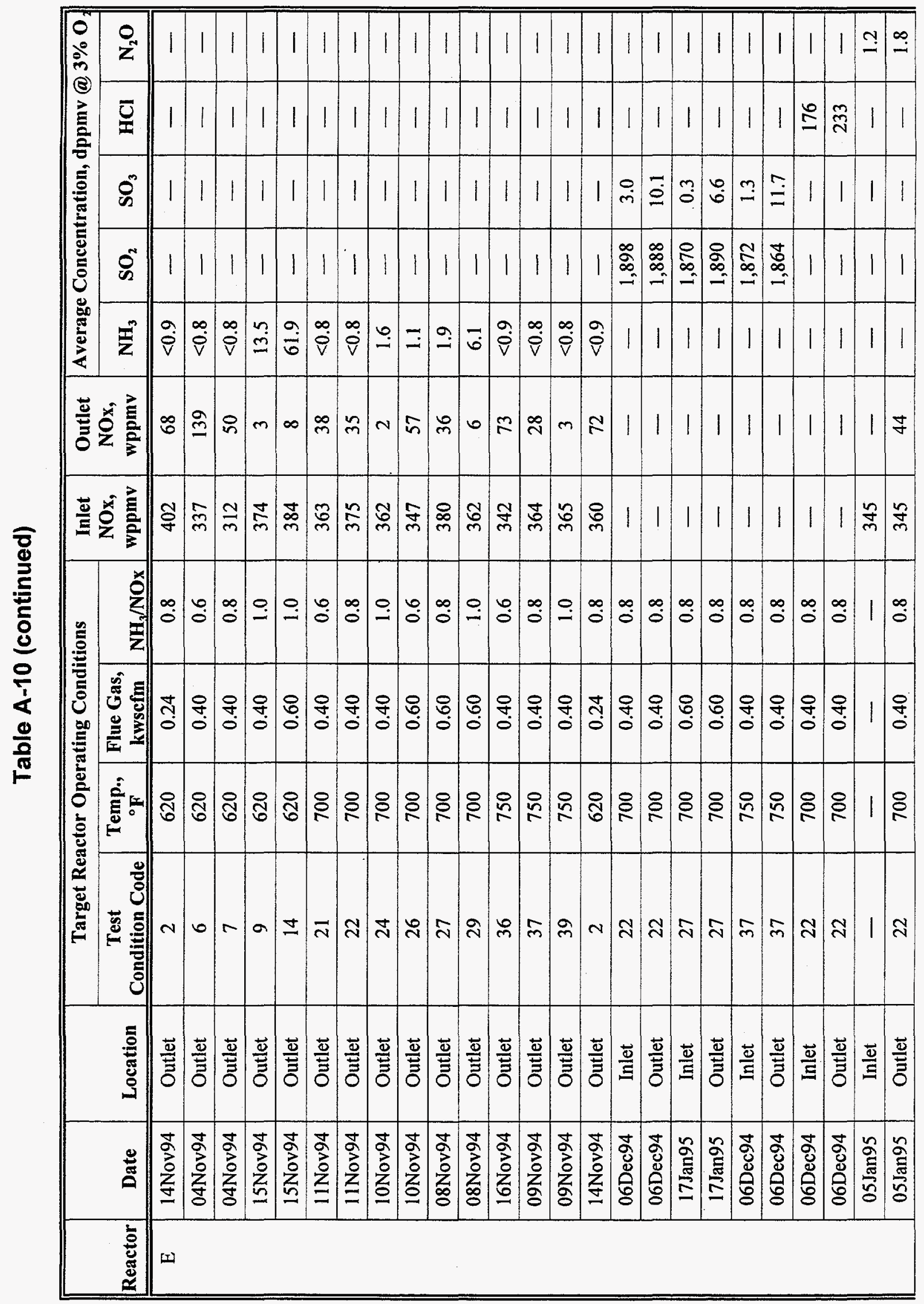


Table A-10 (continued)

\begin{tabular}{|c|c|c|c|c|c|c|c|c|c|c|c|c|c|}
\hline \multirow[b]{2}{*}{ Reactor } & \multirow[b]{2}{*}{ Date } & \multirow[b]{2}{*}{ Location } & \multicolumn{4}{|c|}{ Target Reactor Operating Conditions } & \multirow{2}{*}{$\begin{array}{c}\text { Inlet } \\
\text { NOx, } \\
\text { wppmv }\end{array}$} & \multirow{2}{*}{$\begin{array}{l}\text { Outlet } \\
\text { NOx, } \\
\text { wppmv }\end{array}$} & \multicolumn{5}{|c|}{ Average Concentration, dppmv @ $3 \% 0$} \\
\hline & & & $\begin{array}{c}\text { Test } \\
\text { Condition Code }\end{array}$ & $\begin{array}{c}\text { Temp., } \\
{ }^{\circ} \mathbf{F}\end{array}$ & $\begin{array}{c}\text { Flue Gas, } \\
\text { kwscfm }\end{array}$ & $\mathrm{NH}_{3} / \mathrm{NOx}$ & & & $\mathrm{NH}_{3}$ & $\mathrm{SO}_{2}$ & $\mathrm{SO}_{3}$ & $\mathbf{H C l}$ & $\mathbf{N}_{2} \mathbf{O}$ \\
\hline \multirow[t]{25}{*}{ F } & 15 Nov 94 & Outlet & 2 & 620 & 0.24 & 0.8 & 385 & 19 & $<0.9$ & - & - & - & - \\
\hline & 14Nov94 & Outlet & 6 & 620 & 0.40 & 0.6 & 378 & 64 & 1.3 & - & - & - & - \\
\hline & 14Nov94 & Outlet & 7 & 620 & 0.40 & 0.8 & 396 & 32 & 3.1 & - & - & - & - \\
\hline & 15 Nov94 & Outlet & 9 & 620 & 0.40 & 1.0 & 383 & 7 & 12.2 & - & - & - & - \\
\hline & 03Nov94 & Outlet & 14 & 620 & 0.60 & 1.0 & 325 & 18 & 32.8 & - & - & - & - \\
\hline & 08Nov94 & Outlet & 21 & 700 & 0.40 & 0.6 & 374 & 94 & $<0.8$ & - & - & - & - \\
\hline & 08Nov94 & Outlet & 22 & 700 & 0.40 & 0.8 & 362 & 59 & 1.0 & - & - & - & - \\
\hline & 10Nov94 & Outlet & 24 & 700 & 0.40 & 1.0 & 341 & 4 & 12.5 & - & - & - & - \\
\hline & 04Nov94 & Outlet & 26 & 700 & 0.60 & 0.6 & 327 & 94 & 2.9 & - & - & - & - \\
\hline & 04Nov94 & Outlet & 27 & 700 & 0.60 & 0.8 & 313 & 52 & 4.6 & - & - & - & - \\
\hline & 16 Nov94 & Outlet & 29 & 700 & 0.60 & 1.0 & 338 & 13 & 24.5 & - & - & - & - \\
\hline & 11 Nov94 & Outlet & 36 & 750 & 0.40 & 0.6 & 367 & 72 & 1.1 & - & - & - & - \\
\hline & 09Nov94 & Outlet & 37 & 750 & 0.40 & 0.8 & 348 & 57 & 1.0 & - & - & - & - \\
\hline & 16Nov94 & Outlet & 39 & 750 & 0.40 & 1.0 & 340 & 7 & 2.9 & - & - & - & - \\
\hline & 10Nov94 & Outlet & 26 & 620 & 0.60 & 0.6 & 363 & 109 & 3.4 & - & - & - & - \\
\hline & 07Dec94 & Inlet & 22 & 700 & 0.40 & 0.8 & - & - & - & 1,935 & 0.8 & - & - \\
\hline & 07Dec94 & Outlet & 22 & 700 & 0.40 & 0.8 & - & - & - & 1,942 & 1.1 & - & - \\
\hline & 18Jan95 & Inlet & 27 & 700 & 0.60 & 0.8 & - & - & - & 1,884 & 1.4 & - & - \\
\hline & 18Jan95 & Outlet & 27 & 700 & 0.60 & 0.8 & - & - & - & 1,798 & 0.2 & - & - \\
\hline & 07Dec94 & Inlet & 37 & 750 & 0.40 & 0.8 & - & - & - & 1,907 & 0.7 & - & - \\
\hline & 07Dec94 & Outlet & 37 & 750 & 0.40 & 0.8 & - & - & - & 1,900 & 0.8 & - & - \\
\hline & 07Dec94 & Inlet & 22 & 700 & 0.40 & 0.8 & - & - & - & - & - & 174 & - \\
\hline & 07Dec94 & Outlet & 22 & 700 & 0.40 & 0.8 & - & - & - & - & - & 250 & - \\
\hline & 05Jan95 & Inlet & - & - & - & - & 345 & - & - & - & - & - & 1.2 \\
\hline & 05Jan95 & Outlet & 22 & 700 & 0.40 & 0.8 & 345 & 35 & - & - & - & - & 2.0 \\
\hline
\end{tabular}


Table A-10 (continued)

\begin{tabular}{|c|c|c|c|c|c|c|c|c|c|c|c|c|c|}
\hline \multirow[b]{2}{*}{ Reactor } & \multirow[b]{2}{*}{ Date } & \multirow[b]{2}{*}{ Location } & \multicolumn{4}{|c|}{ Target Reactor Operating Conditions } & \multirow{2}{*}{$\begin{array}{c}\text { Inlet } \\
\text { NOx, } \\
\text { wppmv }\end{array}$} & \multirow{2}{*}{$\begin{array}{l}\text { Outlet } \\
\text { NOx, } \\
\text { wppmv }\end{array}$} & \multicolumn{5}{|c|}{ Average Concentration, dppmv@3\% O } \\
\hline & & & $\begin{array}{c}\text { Test } \\
\text { Condition Code } \\
\end{array}$ & $\begin{array}{c}\text { Temp., } \\
{ }^{\circ} \mathbf{F} \\
\end{array}$ & $\begin{array}{c}\text { Flue Gas, } \\
\text { kwscfm }\end{array}$ & $\mathrm{NH}_{3} / \mathrm{NOx}$ & & & $\mathbf{N H}_{\mathbf{3}}$ & $\mathrm{SO}_{2}$ & $\mathrm{SO}_{3}$ & $\mathbf{H C l}$ & $\mathbf{N}_{2} \mathrm{O}$ \\
\hline \multirow[t]{24}{*}{ G } & $250 \mathrm{ct} 94$ & Outlet & 2 & 620 & 0.24 & 0.8 & 302 & 61 & $<0.8$ & - & - & - & - \\
\hline & $250 c t 94$ & Outlet & 6 & 620 & 0.40 & 0.6 & 302 & 103 & $<0.7$ & - & - & - & - \\
\hline & $260 c t 94$ & Outlet & 7 & 620 & 0.40 & 0.8 & 330 & 36 & 3.2 & - & - & - & - \\
\hline & $260 \operatorname{ct} 94$ & Outlet & 9 & 620 & 0.40 & 1.0 & 319 & 73 & 19.4 & - & - & - & - \\
\hline & 240 ct94 & Outlet & 14 & 620 & 0.60 & 1.0 & 267 & 37 & 13.0 & - & - & - & - \\
\hline & 02Nov94 & Outlet & 21 & 700 & 0.40 & 0.6 & 321 & 96 & 0.9 & - & - & - & - \\
\hline & 03Nov94 & Outlet & 22 & 700 & 0.40 & 0.8 & 336 & 35 & 2.0 & - & - & - & - \\
\hline & 03Nov94 & Outlet & 24 & 700 & 0.40 & 1.0 & 326 & 22 & 10.6 & - & - & - & - \\
\hline & 27Oct94 & Outlet & 26 & 700 & 0.60 & 0.6 & 374 & 98 & 3.6 & - & - & - & - \\
\hline & $270 c t 94$ & Outlet & 27 & 700 & 0.60 & 0.8 & 362 & 60 & 6.0 & - & - & - & - \\
\hline & 08Nov94 & Outlet & 29 & 700 & 0.60 & 1.0 & 377 & 43 & 16.3 & - & - & - & - \\
\hline & 04Nov94 & Outlet & 36 & 750 & 0.40 & 0.6 & 312 & 101 & 1.4 & - & - & - & - \\
\hline & 04Nov94 & Outlet & 37 & 750 & 0.40 & 0.8 & 315 & 67 & 3.2 & - & - & - & - \\
\hline & 280ct94 & Outlet & 39 & 750 & 0.40 & 1.0 & 377 & 18 & 9.0 & - & - & - & - \\
\hline & 08Dec94 & Inlet & 22 & 700 & 0.40 & 0.8 & - & - & - & 1,803 & 0.4 & - & - \\
\hline & $08 \mathrm{Dec} 94$ & Outlet & 22 & 700 & 0.40 & 0.8 & - & - & - & 2,008 & 3.8 & - & - \\
\hline & $08 \mathrm{Dec} 94$ & Inlet & 27 & 700 & 0.60 & 0.8 & - & - & - & 1,833 & 2.2 & - & - \\
\hline & $08 \operatorname{Dec} 94$ & Outlet & 27 & 700 & 0.60 & 0.8 & - & - & - & 1,804 & 4.3 & - & - \\
\hline & 16Jan95 & Inlet & 37 & 750 & 0.40 & 0.8 & - & - & - & 1,999 & 0.6 & & - \\
\hline & 16Jan95 & Outlet & 37 & 750 & 0.40 & 0.8 & - & - & - & 1,940 & 14.8 & - & - \\
\hline & $08 \mathrm{Dec} 94$ & Inlet & 22 & 700 & 0.40 & 0.8 & - & - & - & - & - & 189 & - \\
\hline & 08Dec94 & Outlet & 22 & 700 & 0.40 & 0.8 & - & - & - & - & - & 256 & - \\
\hline & 05Jan95 & Inlet & 22 & 700 & 0.40 & 0.8 & 345 & - & - & - & - & - & 1.2 \\
\hline & 05Jan95 & Outlet & 22 & 700 & 0.40 & 0.8 & 345 & 52 & - & - & - & - & 2.3 \\
\hline
\end{tabular}


Table A-10 (continued)

\begin{tabular}{|c|c|c|c|c|c|c|c|c|c|c|c|c|c|}
\hline \multirow[b]{2}{*}{ Reactor } & \multirow[b]{2}{*}{ Date } & \multirow[b]{2}{*}{ Location } & \multicolumn{4}{|c|}{ Target Reactor Operating Conditions } & \multirow{2}{*}{$\begin{array}{c}\text { Inlet } \\
\text { NOx, } \\
\text { wppmv }\end{array}$} & \multirow{2}{*}{$\begin{array}{l}\text { Outlet } \\
\text { NOx, } \\
\text { wppmv }\end{array}$} & \multicolumn{5}{|c|}{ Average Concentration, dppmv@ $3 \% 0$} \\
\hline & & & $\begin{array}{c}\text { Test } \\
\text { Condition Code }\end{array}$ & $\underset{{ }^{\circ}}{\text { Temp., }}$ & $\begin{array}{c}\text { Flue Gas, } \\
\text { kwscfm }\end{array}$ & $\mathbf{N H}_{3} / \mathbf{N O x}$ & & & $\mathrm{NH}_{3}$ & $\mathrm{SO}_{2}$ & $\mathrm{SO}_{3}$ & $\mathbf{H C l}$ & $\mathrm{N}_{2} \mathrm{O}$ \\
\hline \multirow[t]{24}{*}{$\mathbf{J}$} & $260 \mathrm{ct} 94$ & Outlet & 2 & 620 & 0.24 & 0.8 & 294 & 87 & 1.2 & - & - & - & - \\
\hline & $260 c t 94$ & Outlet & 6 & 620 & 0.40 & 0.6 & 313 & 137 & 0.8 & - & - & - & - \\
\hline & $270 c t 94$ & Outlet & 7 & 620 & 0.40 & 0.8 & 332 & 53 & 1.8 & - & - & - & - \\
\hline & $270 c t 94$ & Outlet & 9 & 620 & 0.40 & 1.0 & 323 & 11 & 7.8 & - & - & - & - \\
\hline & $250 \mathrm{Oct} 94$ & Outlet & 14 & 620 & 0.60 & 1.0 & 308 & 46 & 20.3 & - & - & - & - \\
\hline & 02Nov94 & Outlet & 21 & 700 & 0.40 & 0.6 & 310 & 119 & 0.7 . & - & - & - & - \\
\hline & 02Nov94 & Outlet & 22 & 700 & 0.40 & 0.8 & 300 & 56 & 1.1 & - & - & - & - \\
\hline & 03Nov94 & Outlet & 24 & 700 & 0.40 & 1.0 & 305 & 23 & 2.1 & - & - & - & - \\
\hline & 03Nov94 & Outlet & 26 & 700 & 0.60 & 0.6 & 297 & 113 & 1.5 & - & - & - & - \\
\hline & $310 c t 94$ & Outlet & 27 & 700 & 0.60 & 0.8 & 321 & 59 & 4.8 & - & - & - & - \\
\hline & $310 c t 94$ & Outlet & 29 & 700 & 0.60 & 1.0 & 299 & 20 & 24.4 & - & - & - & - \\
\hline & 09Jan95 & Outlet & 36 & 750 & 0.40 & 0.6 & 224 & 60 & 2.8 & - & - & - & - \\
\hline & $11 \operatorname{Jan} 95$ & Outlet & 37 & 750 & 0.40 & 0.8 & 261 & 37 & 4.6 & - & - & - & - \\
\hline & 09Jan95 & Outlet & 39 & 750 & 0.40 & 1.0 & 227 & 8 & 11.1 & - & - & - & - \\
\hline & 09Dec94 & Inlet & 22 & 700 & 0.40 & 0.8 & - & - & - & 2,033 & 0.7 & - & - \\
\hline & 09Dec94 & Outlet & 22 & 700 & 0.40 & 0.8 & - & - & - & 2,030 & 3.7 & - & - \\
\hline & 12Dec94 & Inlet & 27 & 700 & 0.60 & 0.8 & - & - & - & 2,050 & 1.6 & - & - \\
\hline & 12Dec94 & Outlet & 27 & 700 & 0.60 & 0.8 & - & - & - & 2,078 & 7.6 & - & - \\
\hline & 09Dec94 & Inlet & 37 & 750 & 0.40 & 0.8 & - & - & - & 1,952 & 1.0 & - & - \\
\hline & 09Dec94 & Outlet & 37 & 750 & 0.40 & 0.8 & - & - & - & 1,997 & 12.7 & - & - \\
\hline & 09Dec94 & Inlet & 22 & 700 & 0.40 & 0.8 & - & - & - & - & - & 179 & - \\
\hline & 09Dec94 & Outlet & 22 & 700 & 0.40 & 0.8 & - & - & - & - & - & 244 & - \\
\hline & 04Jan95 & Inlet & 22 & 700 & 0.40 & 0.8 & 361 & - & - & - & - & - & 1.2 \\
\hline & $04 \operatorname{Jan} 95$ & Outlet & 22 & 700 & 0.40 & 0.8 & 360 & 50 & - & - & - & - & 2.5 \\
\hline
\end{tabular}

${ }^{a}$ Dash indicates that no tests were performed at these conditions. 
Table A-11. Parametric Test Data-Test Sequence 5

\begin{tabular}{|c|c|c|c|c|c|c|c|c|c|c|c|c|c|}
\hline \multirow[b]{2}{*}{ Reactor } & \multirow[b]{2}{*}{ Date } & \multirow[b]{2}{*}{ Location } & \multicolumn{4}{|c|}{ Target Reactor Operating Conditions } & \multirow{2}{*}{$\begin{array}{c}\text { Inlet } \\
\text { NOx, } \\
\text { wppmv }\end{array}$} & \multirow{2}{*}{$\begin{array}{l}\text { Outlet } \\
\text { NOx, } \\
\text { wppmv }\end{array}$} & \multicolumn{5}{|c|}{ Average Concentration, dppmv @ 3\% O } \\
\hline & & & $\begin{array}{c}\text { Test } \\
\text { Condition Code }\end{array}$ & $\begin{array}{c}\text { Temp., } \\
{ }^{\circ} \mathrm{F}\end{array}$ & $\begin{array}{c}\text { Flue Gas, } \\
\text { kwsefm }\end{array}$ & $\mathrm{NH}_{3} / \mathrm{NOx}$ & & & $\mathbf{N H}_{3}$ & $\mathrm{SO}_{2}$ & $\mathrm{SO}_{3}$ & $\mathrm{HCl}$ & $\mathbf{N}_{2} \mathbf{O}$ \\
\hline \multirow[t]{20}{*}{ A } & 08 Jun95 & Outlet & 2 & 620 & 3.0 & 0.8 & 347 & 92 & $<0.8$ & $-{ }^{\mathrm{a}}$ & - & - & - \\
\hline & 07Jun95 & Outlet & 6 & 620 & 5.0 & 0.6 & 367 & 125 & $<0.8$ & - & - & - & - \\
\hline & 07Jun95 & Outlet & 7 & 620 & 5.0 & 0.8 & 360 & 60 & $<0.7$ & - & - & - & - \\
\hline & 05Jul95 & Outlet & 9 & 620 & 5.0 & 1.0 & 338 & 19 & 1.6 & - & - & - & - \\
\hline & 07Ju195 & Outlet & 14 & 620 & 6.8 & 1.0 & 338 & 56 & 2.7 & - & - & - & - \\
\hline & 05Jun95 & Outlet & 21 & 700 & 5.0 & 0.6 & 308 & 117 & $<0.9$ & - & - & - & - \\
\hline & 04Jun95 & Outlet & 22 & 700 & 5.0 & 0.8 & 357 & 52 & 4.3 & - & - & - & - \\
\hline & 06Ju195 & Outlet & 24 & 700 & 5.0 & 1.0 & 335 & 18 & $<0.9$ & - & - & - & - \\
\hline & 06Jun95 & Outlet & 26 & 700 & 6.4 & 0.6 & 325 & 134 & $<0.7$ & - & - & - & - \\
\hline & 05Jun95 & Outlet & 27 & 700 & 6.0 & 0.8 & 249 & 84 & $<0.8$ & - & - & - & - \\
\hline & 10Ju195 & Outlet & 29 & 700 & 6.4 & 1.0 & 336 & 45 & 1.6 & - & - & - & - \\
\hline & 14Jun95 & Outlet & 36 & 750 & 5.0 & 0.6 & 365 & 152 & $<0.8$ & - & - & - & - \\
\hline & 14Jun95 & Outlet & 37 & 750 & 5.0 & 0.8 & 369 & 99 & $<0.9$ & - & - & - & - \\
\hline & 06Jul95 & Outlet & 39 & 750 & 5.0 & 1.0 & 321 & 39 & 1.6 & - & - & - & - \\
\hline & 01Jun95 & Inlet & 22 & 700 & 5.0 & 0.8 & - & - & - & 1,564 & 1.0 & - & - \\
\hline & 01 Jun95 & Outlet & 22 & 700 & 5.0 & 0.8 & - & - & - & 1,534 & 7.7 & - & - \\
\hline & 03Jul95 & Inlet & 22 & 700 & 5.0 & 0.8 & - & - & - & - & - & 132 & - \\
\hline & 03Ju195 & Outlet & 22 & 700 & 5.0 & 0.8 & - & - & - & - & - & 86 & - \\
\hline & 16Jun95 & Inlet & 22 & 700 & 5.0 & 0.8 & - & - & - & - & - & - & 2.0 \\
\hline & 16Jun95 & Outlet & 22 & 700 & 5.0 & 0.8 & - & - & - & - & - & -- & 1.6 \\
\hline \multirow[t]{4}{*}{$B$} & 06Jun95 & Outlet & 2 & 620 & 3.0 & 0.8 & 348 & 48 & $<0.9$ & - & - & - & - \\
\hline & 07Jun95 & Outlet & 6 & 620 & 5.0 & 0.6 & 363 & 110 & $<0.8$ & - & - & - & - \\
\hline & 07Jun95 & Outlet & 7 & 620 & 5.0 & 0.8 & 356 & 50 & $<0.8$ & - & - & - & - \\
\hline & 07Jun95 & Outlet & 9 & 620 & 5.0 & 1.0 & 338 & 2 & 2.4 & - & - & - & - \\
\hline
\end{tabular}


Table A-11 (continued)

\begin{tabular}{|c|c|c|c|c|c|c|c|c|c|c|c|c|c|}
\hline \multirow[b]{2}{*}{ Reactor } & \multirow[b]{2}{*}{ Date } & \multirow[b]{2}{*}{ Location } & \multicolumn{4}{|c|}{ Target Reactor Operating Conditions } & \multirow{2}{*}{$\begin{array}{c}\text { Inlet } \\
\text { NOx, } \\
\text { wppmv }\end{array}$} & \multirow{2}{*}{$\begin{array}{l}\text { Outlet } \\
\text { NOx, } \\
\text { wppmv }\end{array}$} & \multicolumn{5}{|c|}{ Average Concentration, dppmv @ 3\% O } \\
\hline & & & $\begin{array}{c}\text { Test } \\
\text { Condition Code }\end{array}$ & $\begin{array}{c}\text { Temp., } \\
{ }^{\circ} \mathbf{F}\end{array}$ & $\begin{array}{c}\text { Flue Gas, } \\
\text { kwscfm }\end{array}$ & $\mathrm{NH}_{3} / \mathrm{NOx}$ & & & $\mathbf{N H}_{3}$ & $\mathrm{SO}_{2}$ & $\mathrm{SO}_{3}$ & $\mathrm{HCl}$ & $\mathbf{N}_{2} \mathbf{O}$ \\
\hline \multirow[t]{15}{*}{ B } & 07Jun95 & Outlet & 14 & 620 & 7.3 & 1.0 & 344 & 6 & 5.9 & - & - & - & - \\
\hline & 05Jun95 & Outlet & 21 & 700 & 5.0 & 0.6 & 256 & 60 & $<0.9$ & - & - & - & - \\
\hline & 04Jun95 & Outlet & 22 & 700 & 5.0 & 0.8 & 353 & 45 & $<0.9$ & - & - & - & - \\
\hline & 12Jun95 & Outlet & 22 & 700 & 5.0 & 0.8 & 366 & 31 & $<0.7$ & - & - & - & - \\
\hline & 06Ju195 & Outlet & 24 & 700 & 5.0 & 1.0 & 336 & 2 & 1.3 & - & - & - & - \\
\hline & 06Jun95 & Outlet & 26 & 700 & 7.5 & 0.6 & 347 & 117 & $<0.8$ & - & - & - & - \\
\hline & 05Jun95 & Outlet & 27 & 700 & 6.8 & 0.8 & 340 & 65 & $<0.9$ & - & - & - & - \\
\hline & 08Ju195 & Outlet & 29 & 700 & 6.6 & 1.0 & 349 & 28 & 2.6 & - & - & - & - \\
\hline & 09Jun95 & Outlet & 36 & 750 & 5.0 & 0.6 & 350 & 123 & $<0.6$ & - & - & - & - \\
\hline & 14Jun95 & Outlet & 37 & 750 & 5.0 & 0.8 & 365 & 61 & $<0.8$ & - & - & - & - \\
\hline & 05Jul95 & Outlet & 39 & 750 & 5.0 & 1.0 & 325 & 7 & 1.6 & - & - & - & - \\
\hline & $01 \mathrm{Jul95}$ & Inlet & 22 & 700 & 5.0 & 0.8 & - & - & - & 1,499 & 0.4 & - & - \\
\hline & 01Jul95 & Outlet & 22 & 700 & 5.0 & 0.8 & - & - & - & 1,464 & 0.6 & - & - \\
\hline & 16Jun95 & Inlet & 22 & 700 & 5.0 & 0.8 & - & - & - & - & - & - & 2.0 \\
\hline & 16Jun95 & Outlet & 22 & 700 & 5.0 & 0.8 & - & - & - & - & - & - & 1.6 \\
\hline \multirow[t]{10}{*}{ C } & $14 \mathrm{Jun} 95$ & Outlet & 2 & 620 & 3.0 & 0.8 & 364 & 46 & $<0.9$ & - & - & - & - \\
\hline & 12Jun95 & Outlet & 6 & 620 & 5.0 & 0.6 & 384 & 73 & 3.4 & - & - & - & - \\
\hline & 12Jun95 & Outlet & 7 & 620 & 5.0 & 0.8 & 382 & 15 & 13.5 & - & - & - & - \\
\hline & 12Jun95 & Outlet & 9 & 620 & 5.0 & 1.0 & 325 & 4 & 46.4 & - & - & - & - \\
\hline & 12Jul95 & Outlet & 14 & 620 & 6.5 & 1.0 & 342 & 6 & 46.9 & - & - & - & - \\
\hline & 10Jun95 & Outlet & 21 & 700 & 5.0 & 0.6 & 337 & 105 & 2.4 & - & - & - & - \\
\hline & 10Jun95 & Outlet & 22 & 700 & 5.0 & 0.8 & 336 & 43 & 5.5 & - & - & - & - \\
\hline & 13Jul95 & Outlet & 24 & 700 & 5.0 & 1.0 & 332 & 4 & 27.2 & - & - & - & - \\
\hline & 10Jun95 & Outlet & 26 & 700 & 6.4 & 0.6 & 338 & 101 & 6.5 & - & - & - & - \\
\hline & 13Jun95 & Outlet & 27 & 700 & 6.4 & 0.8 & 383 & 43 & 14 & - & - & - & - \\
\hline
\end{tabular}


Table A-11 (continued)

\begin{tabular}{|c|c|c|c|c|c|c|c|c|c|c|c|c|c|}
\hline \multirow[b]{2}{*}{ Reactor } & \multirow[b]{2}{*}{ Date } & \multirow[b]{2}{*}{ Location } & \multicolumn{4}{|c|}{ Target Reactor Operating Conditions } & \multirow{2}{*}{$\begin{array}{c}\text { Inlet } \\
\text { NOx, } \\
\text { wppmv }\end{array}$} & \multirow{2}{*}{$\begin{array}{c}\text { Outlet } \\
\text { NOx, } \\
\text { wppmv }\end{array}$} & \multicolumn{5}{|c|}{ Average Concentration, dppmv @ $3 \% 0$} \\
\hline & & & $\begin{array}{c}\text { Test } \\
\text { Condition Code }\end{array}$ & $\begin{array}{c}\text { Temp., } \\
{ }^{\circ} \mathbf{F}\end{array}$ & \begin{tabular}{|c|}
$\begin{array}{c}\text { Flue Gas, } \\
\text { kwscfm }\end{array}$ \\
\end{tabular} & $\mathrm{NH}_{3} / \mathrm{NO} \mathrm{x}$ & & & $\mathbf{N H}_{3}$ & $\mathrm{SO}_{2}$ & $\mathrm{SO}_{3}$ & $\mathbf{H C l}$ & $\mathbf{N}_{2} \mathbf{O}$ \\
\hline \multirow[t]{8}{*}{$\mathrm{C}$} & 08Ju195 & Outlet & 29 & 700 & 6.3 & 1.0 & 353 & 6 & 34.7 & - & - & - & - \\
\hline & 13Jun95 & Outlet & 36 & 750 & 5.0 & 0.6 & 387 & 113 & 3.2 & - & - & - & - \\
\hline & 13Jun95 & Outlet & 37 & 750 & 5.0 & 0.8 & 386 & 57 & 6.4 & - & - & - & - \\
\hline & $11 \mathrm{Jul95}$ & Outlet & 39 & 750 & 5.0 & 1.0 & 317 & 15 & 10.9 & - & - & - & - \\
\hline & 01Jul95 & Inlet & 22 & 700 & 5.0 & 0.8 & - & - & - & 1,547 & 1.2 & - & - \\
\hline & 01 Jul95 & Outlet & 22 & 700 & 5.0 & 0.8 & - & - & - & 1,488 & 8.8 & - & - \\
\hline & 16Jun95 & Inlet & 22 & 700 & 5.0 & 0.8 & - & - & - & - & - & - & 2.0 \\
\hline & 16Jun95 & Outlet & 22 & 700 & 5.0 & 0.8 & - & - & - & - & - & - & 2.5 \\
\hline \multirow[t]{17}{*}{$\mathrm{D}$} & 06Jun95 & Outlet & 2 & 620 & 0.24 & 0.8 & 327 & 12 & 1.0 & - & - & - & - \\
\hline & 07Jun95 & Outlet & 6 & 620 & 0.40 & 0.6 & 368 & 73 & 2.0 & - & - & - & - \\
\hline & 06Jun95 & Outlet & 7 & 620 & 0.40 & 0.8 & 346 & 51 & 5.5 & - & - & - & - \\
\hline & 05Jul95 & Outlet & 9 & 620 & 0.40 & 1.0 & 338 & 46 & 13.2 & - & - & - & - \\
\hline & 07Jul95 & Outlet & 14 & 620 & 0.60 & 1.0 & 339 & 77 & 35.7 & - & - & - & - \\
\hline & 05Jun95 & Outlet & 21 & 700 & 0.40 & 0.6 & 251 & 48 & 1.7 & - & - & - & - \\
\hline & 04Jun94 & Outlet & 22 & 700 & 0.40 & 0.8 & 357 & 46 & 3.4 & - & - & - & - \\
\hline & 06Ju195 & Outlet & 24 & 700 & 0.40 & 1.0 & 334 & 34 & 4.8 & - & - & - & - \\
\hline & 07Jun95 & Outlet & 26 & 700 & 0.60 & 0.6 & 353 & 87 & 4.5 & - & - & - & - \\
\hline & 09Jun95 & Outlet & 27 & 700 & 0.60 & 0.8 & 350 & 73 & 9.7 & - & - & - & - \\
\hline & 08Jul95 & Outlet & 29 & 700 & 0.60 & 1.0 & 350 & 56 & 19.3 & - & - & - & - \\
\hline & 13Jun95 & Outlet & 36 & 750 & 0.40 & 0.6 & 386 & 89 & 1.6 & - & - & - & - \\
\hline & 13Jun95 & Outlet & 37 & 750 & 0.40 & 0.8 & 387 & 62 & 2.7 & - & - & - & - \\
\hline & 06Jul95 & Outlet & 39 & 750 & 0.40 & 1.0 & 323 & 41 & 4.7 & - & - & - & - \\
\hline & 02Jun95 & Inlet & 22 & 700 & 0.40 & 0.8 & - & - & - & 1,669 & 4.2 & - & - \\
\hline & 02Jun95 & Outlet & 22 & 700 & 0.40 & 0.8 & - & - & - & 1,683 & 1.3 & - & - \\
\hline & 16Jun95 & Inlet & 22 & 700 & 0.40 & 0.8 & - & - & - & - & - & - & 2.0 \\
\hline
\end{tabular}


Table A-11 (continued)

\begin{tabular}{|c|c|c|c|c|c|c|c|c|c|c|c|c|c|}
\hline \multirow[b]{2}{*}{ Reactor } & \multirow[b]{2}{*}{ Date } & \multirow[b]{2}{*}{ Location } & \multicolumn{4}{|c|}{ Target Reactor Operating Conditions } & \multirow{2}{*}{$\begin{array}{c}\text { Inlet } \\
\text { NOx, } \\
\text { wppmv }\end{array}$} & \multirow{2}{*}{$\begin{array}{l}\text { Outlet } \\
\text { NOx, } \\
\text { wppmv }\end{array}$} & \multicolumn{5}{|c|}{ Average Concentration, dppmv @ 3\% O } \\
\hline & & & $\begin{array}{c}\text { Test } \\
\text { Condition Code }\end{array}$ & $\begin{array}{c}\text { Temp., } \\
{ }^{\circ} \mathbf{F}\end{array}$ & $\begin{array}{c}\text { Flue Gas, } \\
\text { kwscfm }\end{array}$ & $\mathbf{N H}_{3} / \mathrm{NOx}$ & & & $\mathrm{NH}_{3}$ & $\mathrm{SO}_{2}$ & $\mathrm{SO}_{3}$ & $\mathbf{H C l}$ & $\mathbf{N}_{2} \mathbf{O}$ \\
\hline $\mathrm{D}$ & 16Jun95 & Outlet & 22 & 700 & 0.40 & 0.8 & - & - & - & - & - & - & 2.1 \\
\hline \multirow[t]{18}{*}{$\mathrm{E}$} & 08Jun95 & Outlet & 2 & 620 & 0.24 & 0.8 & 348 & 117 & $<0.7$ & - & - & - & - \\
\hline & 07Jun95 & Outlet & 6 & 620 & 0.40 & 0.6 & 361 & 149 & $<0.8$ & - & - & - & - \\
\hline & 07Jun95 & Outlet & 7 & 620 & 0.40 & 0.8 & 357 & 118 & $<0.8$ & - & - & - & - \\
\hline & 07Jul95 & Outlet & 9 & 620 & 0.40 & 1.0 & 338 & 84 & 0.9 & - & - & - & - \\
\hline & 07Jul95 & Outlet & 14 & 620 & 0.60 & 1.0 & 344 & 56 & 3.6 & - & - & - & - \\
\hline & 05Jun95 & Outlet & 21 & 700 & 0.40 & 0.6 & 257 & 122 & $<0.7$ & - & - & - & - \\
\hline & 04Jun95 & Outlet & 22 & 700 & 0.40 & 0.8 & 356 & 108 & 1.0 & - & - & - & - \\
\hline & 06Jul95 & Outlet & 24 & 700 & 0.40 & 1.0 & 336 & 57 & $<0.8$ & - & - & - & - \\
\hline & 06Jun95 & Outlet & 26 & 700 & 0.60 & 0.6 & 349 & 157 & 0.8 & - & - & - & - \\
\hline & 05Jun95 & Outlet & 27 & 700 & 0.60 & 0.8 & 340 & 103 & 1.0 & - & - & - & - \\
\hline & 08Jul95 & Outlet & 29 & 700 & 0.60 & 1.0 & 352 & 66 & 2.6 & - & - & - & - \\
\hline & 15Jun95 & Outlet & 36 & 750 & 0.40 & 0.6 & 377 & 121 & $<0.7$ & - & - & - & - \\
\hline & 15Jun95 & Outlet & 37 & 750 & 0.40 & 0.8 & 388 & 63 & $<0.7$ & - & - & - & - \\
\hline & 05Ju195 & Outlet & 39 & 750 & 0.40 & 1.0 & 325 & 73 & $<0.7$ & - & - & - & - \\
\hline & 02Jun95 & Inlet & 22 & 700 & 0.40 & 0.8 & - & - & - & 1,666 & 4.9 & - & - \\
\hline & 02Jun95 & Outlet & 22 & 700 & 0.40 & 0.8 & - & - & - & 1,691 & 5.4 & - & - \\
\hline & 16Jun95 & Inlet & 22 & 700 & 0.40 & 0.8 & - & - & - & - & - & - & 2.0 \\
\hline & 16Jun95 & Outlet & 22 & 700 & 0.40 & 0.8 & - & - & - & - & - & - & 1.8 \\
\hline \multirow[t]{6}{*}{$\mathrm{F}$} & 15Jun95 & Outlet & 2 & 620 & 0.24 & 0.8 & 386 & 15 & $<0.7$ & - & - & - & - \\
\hline & 08Jun95 & Outlet & 6 & 620 & 0.40 & 0.6 & 348 & 117 & 0.9 & - & - & - & - \\
\hline & 08Jun95 & Outlet & 7 & 620 & 0.40 & 0.8 & 349 & 85 & 1.6 & - & - & - & - \\
\hline & $12 \mathrm{Jul} 95$ & Outlet & 9 & 620 & 0.40 & 1.0 & 328 & 69 & 2.0 & - & - & - & - \\
\hline & $10 \mathrm{Jul} 95$ & Outlet & 14 & 620 & 0.60 & 1.0 & 331 & 65 & 12.4 & - & - & - & - \\
\hline & 12Jun95 & Outlet & 21 & 700 & 0.40 & 0.6 & 383 & 116 & 1.3 & - & - & - & - \\
\hline
\end{tabular}


Table A-11 (continued)

\begin{tabular}{|c|c|c|c|c|c|c|c|c|c|c|c|c|c|}
\hline \multirow[b]{2}{*}{ Reactor } & \multirow[b]{2}{*}{ Date } & \multirow[b]{2}{*}{ Location } & \multicolumn{4}{|c|}{ Target Reactor Operating Conditions } & \multirow{2}{*}{$\begin{array}{c}\text { Inlet } \\
\text { NOx, } \\
\text { wppmv }\end{array}$} & \multirow{2}{*}{$\begin{array}{c}\text { Outlet } \\
\text { NOx, } \\
\text { wppmv }\end{array}$} & \multicolumn{5}{|c|}{ Average Concentration, dppmv@ $3 \% \mathrm{O}_{2}$} \\
\hline & & & $\begin{array}{c}\text { Test } \\
\text { Condition Code }\end{array}$ & $\begin{array}{c}\text { Temp., } \\
{ }^{\circ} \mathbf{F}\end{array}$ & $\begin{array}{c}\text { Flue Gas, } \\
\text { kwscfm }\end{array}$ & $\mathrm{NH}_{3} / \mathrm{NOx}$ & & & $\mathrm{NH}_{3}$ & $\mathrm{SO}_{2}$ & $\mathrm{SO}_{3}$ & $\mathbf{H C l}$ & $\mathrm{N}_{2} \mathrm{O}$ \\
\hline \multirow[t]{12}{*}{$\mathrm{F}$} & 04Jun95 & Outlet & 22 & 700 & 0.40 & 0.8 & 340 & 65 & 1.6 & - & - & - & - \\
\hline & $11 \mathrm{Jul} 95$ & Outlet & 24 & 700 & 0.40 & 1.0 & 312 & 72 & 1.2 & - & - & - & - \\
\hline & 10Jun95 & Outlet & 26 & 700 & 0.60 & 0.6 & 337 & 132 & 2.8 & - & - & - & - \\
\hline & 10Jun95 & Outlet & 27 & 700 & 0.60 & 0.8 & 339 & 103 & 4.6 & - & - & - & - \\
\hline & $11 \mathrm{Jul} 95$ & Outlet & 29 & 700 & 0.60 & 1.0 & 322 & 77 & 5.2 & - & - & - & - \\
\hline & 09Jun95 & Outlet & 36 & 750 & 0.40 & 0.6 & 342 & 127 & 1.3 & - & - & - & - \\
\hline & 09Jun95 & Outlet & 37 & 750 & 0.40 & 0.8 & 348 & 103 & 1.5 & - & - & - & - \\
\hline & 10Jul95 & Outlet & 39 & 750 & 0.40 & 1.0 & 343 & 68 & 1.8 & - & - & - & - \\
\hline & 03Jun95 & Inlet & 22 & 700 & 0.40 & 0.8 & - & - & - & 1,754 & 4.8 & - & - \\
\hline & 03Jun95 & Outlet & 22 & 700 & 0.40 & 0.8 & - & - & - & 1,736 & 1.2 & - & - \\
\hline & 16Jun95 & Inlet & 22 & 700 & 0.40 & 0.8 & - & - & - & - & - & - & 2.0 \\
\hline & 16Jun95 & Outlet & 22 & 700 & 0.40 & 0.8 & - & - & - & - & - & - & 2.2 \\
\hline \multirow[t]{13}{*}{$\mathrm{G}$} & 13Jun95 & Outlet & 2 & 620 & 0.24 & 0.8 & 384 & 105 & $<0.7$ & - & - & - & - \\
\hline & 09Jun95 & Outlet & 6 & 620 & 0.40 & 0.6 & 342 & 150 & $<0.7$ & - & - & - & - \\
\hline & 09Jun95 & Outlet & 7 & 620 & 0.40 & 0.8 & 348 & 114 & 0.8 & - & - & - & - \\
\hline & 10Jul95 & Outlet & 9 & 620 & 0.40 & 1.0 & 336 & 83 & 2.6 & - & - & - & - \\
\hline & 10Jul95 & Outlet & 14 & 620 & 0.60 & 1.0 & 331 & 80 & 6.8 & - & - & - & - \\
\hline & 08Jun95 & Outlet & 21 & 700 & 0.40 & 0.6 & 350 & 157 & $<0.6$ & - & - & - & - \\
\hline & 08Jun95 & Outlet & 22 & 700 & 0.40 & 0.8 & 348 & 128 & 0.8 & - & - & - & - \\
\hline & 12Jul95 & Outlet & 24 & 700 & 0.40 & 1.0 & 342 & 123 & 2.4 & - & - & - & - \\
\hline & 12Jun95 & Outlet & 26 & 700 & 0.60 & 0.6 & 369 & 151 & 2.6 & - & - & - & - \\
\hline & 12Jun95 & Outlet & 27 & 700 & 0.60 & 0.8 & 384 & 112 & 5.9 & - & - & - & - \\
\hline & 13Jul95 & Outlet & 29 & 700 & 0.60 & 1.0 & 342 & 73 & 6.5 & - & - & - & - \\
\hline & 14Jun95 & Outlet & 36 & 750 & 0.40 & 0.6 & 369 & 164 & $<0.7$ & - & - & - & - \\
\hline & 14Jun95 & Outlet & 37 & 750 & 0.40 & 0.8 & 366 & 127 & 1.0 & - & - & - & - \\
\hline
\end{tabular}


Table A-11 (continued)

\begin{tabular}{|c|c|c|c|c|c|c|c|c|c|c|c|c|c|}
\hline \multirow[b]{2}{*}{ Reactor } & \multirow[b]{2}{*}{ Date } & \multirow[b]{2}{*}{ Location } & \multicolumn{4}{|c|}{ Target Reactor Operating Conditions } & \multirow{2}{*}{$\begin{array}{c}\text { Inlet } \\
\text { NOx, } \\
\text { wppmv }\end{array}$} & \multirow{2}{*}{$\begin{array}{l}\text { Outlet } \\
\text { NOx, } \\
\text { wppmv }\end{array}$} & \multicolumn{5}{|c|}{ Average Concentration, dppmv @ 3\% 0} \\
\hline & & & $\begin{array}{c}\text { Test } \\
\text { Condition Code }\end{array}$ & $\underset{{ }^{\circ} \mathbf{F}}{\text { Temp., }}$ & $\begin{array}{c}\text { Flue Gas, } \\
\text { kwscfm }\end{array}$ & $\mathrm{NH}_{3} / \mathrm{NOx}$ & & & $\mathrm{NH}_{3}$ & $\mathrm{SO}_{2}$ & $\mathrm{SO}_{3}$ & $\mathbf{H C l}$ & $\mathrm{N}_{2} \mathrm{O}$ \\
\hline \multirow[t]{23}{*}{$\mathbf{J}$} & $11 \mathrm{Jul} 95$ & Outlet & 39 & 750 & 0.40 & 1.0 & 317 & 100 & 3.3 & - & - & - & - \\
\hline & 03Jun95 & Inlet & 22 & 700 & 0.40 & 0.8 & - & - & - & 1,744 & 6.1 & - & - \\
\hline & 03Jun95 & Outlet & 22 & 700 & 0.40 & 0.8 & - & - & - & 1,663 & 0.3 & - & - \\
\hline & 16Jun95 & Inlet & 22 & 700 & 0.40 & 0.8 & - & - & - & - & - & - & 2.0 \\
\hline & 16Jun95 & Outlet & 22 & 700 & 0.40 & 0.8 & - & - & - & - & - & - & 1.6 \\
\hline & 15Jun95 & Outlet & 2 & 620 & 0.24 & 0.8 & 210 & 99 & 0.9 & - & - & - & - \\
\hline & 15Jun95 & Outlet & 6 & 620 & 0.40 & 0.6 & 229 & 133 & 1.0 & - & - & - & - \\
\hline & 15Jun95 & Outlet & 7 & 620 & 0.40 & 0.8 & 233 & 106 & 1.3 & - & - & - & - \\
\hline & 10Jul95 & Outlet & 9 & 620 & 0.40 & 1.0 & 255 & 107 & 2.2 & - & - & - & - \\
\hline & $11 \mathrm{Jul} 95$ & Outlet & 14 & 620 & 0.60 & 1.0 & 233 & 57 & 5.1 & - & - & - & - \\
\hline & 16Jun95 & Outlet & 21 & 700 & 0.40 & 0.6 & 222 & 114 & $<0.8$ & - & - & - & - \\
\hline & 16Jun95 & Outlet & 22 & 700 & 0.40 & 0.8 & 225 & 110 & 0.8 & - & - & - & - \\
\hline & 13Jul95 & Outlet & 24 & 700 & 0.40 & 1.0 & 238 & 72 & 2.5 & - & - & - & - \\
\hline & 16Jun95 & Outlet & 26 & 700 & 0.60 & 0.6 & 229 & 123 & 1.1 & - & - & - & - \\
\hline & 17Jun95 & Outlet & 27 & 700 & 0.60 & 0.8 & 223 & 100 & 1.4 & - & - & - & - \\
\hline & 11Jul95 & Outlet & 29 & 700 & 0.60 & 1.0 & 234 & 62 & 3.6 & - & - & - & - \\
\hline & 17Jun95 & Outlet & 36 & 750 & 0.40 & 0.6 & 206 & 118 & $<0.8$ & - & - & - & - \\
\hline & 17Jun95 & Outlet & 37 & 750 & 0.40 & 0.8 & 211 & 107 & 0.9 & - & - & - & - \\
\hline & 13Jul95 & Outlet & 39 & 750 & 0.40 & 1.0 & 231 & 74 & 2.5 & - & - & - & - \\
\hline & 01Ju195 & Inlet & 22 & 700 & 0.40 & 0.8 & - & - & - & 1,568 & 6.6 & - & - \\
\hline & 01 Jul95 & Outlet & 22 & 700 & 0.40 & 0.8 & - & - & - & 1,490 & 11.2 & - & - \\
\hline & 16Jun95 & Inlet & 22 & 700 & 0.40 & 0.8 & - & - & - & - & - & - & 2.0 \\
\hline & 16Jun95 & Outlet & 22 & 700 & 0.40 & 0.8 & - & - & - & - & - & - & 2.9 \\
\hline
\end{tabular}

a Dash indicates that no tests were performed at these conditions. 
Table A-12. Monthly Average Coal Analyses

\begin{tabular}{||c|c|c|c|c|c|c|c||}
\hline Manth & Ash,wt\% & $\begin{array}{c}\text { Sulfur, } \\
\text { w\% }\end{array}$ & $\begin{array}{c}\text { Carbon, } \\
\text { wt\% }\end{array}$ & $\begin{array}{c}\text { Hydrogen, } \\
\text { wt\% }\end{array}$ & $\begin{array}{c}\text { Nitrogen, } \\
\text { wt\% }\end{array}$ & $\begin{array}{c}\text { Oxygen, } \\
\text { wt\% }\end{array}$ & $\begin{array}{c}\text { Chlorine, } \\
\text { nnmw }\end{array}$ \\
\hline \hline Mar 93 & 9.24 & 2.83 & 75.05 & 5.09 & 1.52 & 6.27 & 1514 \\
\hline Apr 93 & 8.87 & 3.01 & 74.86 & 5.04 & 1.57 & 6.65 & 1882 \\
\hline May 93 & 9.26 & 2.93 & 75.06 & 5.09 & 1.60 & 6.06 & 1345 \\
\hline Jun 93 & 9.74 & 2.91 & 74.87 & 5.10 & 1.52 & 5.86 & 293 \\
\hline Jul 93 & 10.09 & 3.02 & 74.23 & 4.98 & 1.55 & 6.13 & 1341 \\
\hline Aug 93 & 9.36 & 2.86 & 74.77 & 5.06 & 1.57 & 6.38 & 1429 \\
\hline Sep 93 & 10.55 & 2.94 & 73.95 & 4.96 & 1.57 & 6.03 & 1716 \\
\hline Oct 93 & 10.23 & 2.51 & 73.74 & 5.00 & 1.57 & 6.95 & 812 \\
\hline Nov 93 & 9.87 & 2.28 & 74.62 & 4.95 & 1.63 & 6.65 & 1210 \\
\hline Dec 93 & 9.01 & 2.62 & 75.51 & 5.04 & 1.66 & 6.16 & 1395 \\
\hline Jan 94 & 9.84 & 2.80 & 75.27 & 4.97 & 1.59 & 5.53 & 858 \\
\hline Feb 94 & 9.39 & 2.88 & 75.08 & 4.94 & 1.58 & 6.13 & 1116 \\
\hline Mar 94 & 9.69 & 2.78 & 75.31 & 4.99 & 1.59 & 5.64 & 1759 \\
\hline Apr 94 & 8.86 & 2.60 & 75.06 & 4.91 & 1.59 & 6.98 & 3403 \\
\hline May 94 & 8.92 & 2.78 & 75.10 & 4.96 & 1.57 & 6.67 & 2236 \\
\hline Jun 94 & 8.65 & 2.68 & 74.69 & 5.04 & 1.56 & 7.38 & 2092 \\
\hline Jul 94 & 8.63 & 2.64 & 74.97 & 5.02 & 1.59 & 7.15 & 2391 \\
\hline Aug 94 & 8.91 & 2.44 & 74.73 & 4.95 & 1.62 & 7.35 & 1957 \\
\hline Sep 94 & 9.08 & 2.63 & 74.36 & 4.99 & 1.58 & 7.36 & 1801 \\
\hline Oct 94 & 9.18 & 2.54 & 74.31 & 4.97 & 1.57 & 7.43 & 2630 \\
\hline Nov 94 & 8.96 & 2.42 & 74.92 & 5.00 & 1.61 & 7.09 & 2445 \\
\hline Dec 94 & 10.04 & 2.51 & 73.29 & 4.93 & 1.59 & 7.64 & 3039 \\
\hline Jan 95 & 9.46 & 2.24 & 74.26 & 4.99 & 1.60 & 7.45 & 3073 \\
\hline May 95 & 9.73 & 2.19 & 73.71 & 4.81 & 1.58 & 7.98 & 1477 \\
\hline Jun 95 & 8.40 & 1.89 & 76.12 & 5.07 & 1.56 & 6.96 & 2538 \\
\hline Ju195 & 7.75 & 1.14 & 77.40 & 5.11 & 1.61 & 6.99 & 185 \\
\hline \hline
\end{tabular}

${ }^{a}$ All concentrations presented on dry basis. 